\author{
UNIVERSIDADE DE SÃo PAULO \\ FaCUldade De Filosofia, Letras E CiÊnCIAS Humanas \\ DEPARTAMENTO DE SOCIOLOGIA \\ Programa de Pós-GRAduaÇÃo em Sociologia
}

ROMULO LELIS LIMA

\title{
A Elaboração da Sociologia Durkheimiana da Religião: a colaboração entre Émile Durkheim, Henri Hubert e Marcel Mauss
}

Versão Corrigida

SÃo PAUlo

2021 
ROMULO LELIS LIMA

\section{A Elaboração da Sociologia Durkheimiana da Religião: a colaboração entre Émile Durkheim, Henri Hubert e Marcel Mauss}

Versão Corrigida

Tese de Doutorado Programa de Pós-Graduação em Sociologia da Faculdade de Filosofia, Letras e Ciências Humanas da Universidade de São Paulo como parte dos requisitos para obtenção do título de Doutor em Sociologia.

Orientador: Prof. Dr. Fernando Antonio Pinheiro Filho Coorientador: Prof. Dr. Steven Lukes

SÃO PAULO 
Autorizo a reprodução e divulgação total ou parcial deste trabalho, por qualquer meio convencional ou eletrônico, para fins de estudo e pesquisa, desde que citada a fonte.

Catalogação na Publicação

Serviço de Biblioteca e Documentação

Faculdade de Filosofia, Letras e Ciências Humanas da Universidade de São Paulo

L5 $41 e$

Lelis, Romulo

A Elaboração da Sociologia Durkheimiana da

Religião: a colaboração entre Émile Durkheim, Henri

Hubert e Marcel Mauss / Romulo Lelis; orientador

Fernando Antonio Pinheiro Filho - São Paulo, 2021.

$288 \mathrm{f}$.

Tese (Doutorado)- Faculdade de Filosofia, Letras e Ciências Humanas da Universidade de São Paulo.

Departamento de Sociologia. Área de concentração: Sociologia.

1. ESCOLAS SOCIOLÓGICAS. 2. RITUAIS RELIGIOSOS. 3. PERFORMANCE. 4. EXTASE RELIGIOSO. 5. ESTÉTICA (ARTE). I. Pinheiro Filho, Fernando Antonio, orient. II. Título. 


\section{ENTREGA DO EXEMPLAR CORRIGIDO DA DISSERTAÇÃO/TESE \\ Termo de Anuência do (a) orientador (a)}

Nome do (a) aluno (a): Romulo Lelis Lima

Data da defesa: 19/07/2021

Nome do Prof. (a) orientador (a): Fernando Antonio Pinheiro Filho

Nos termos da legislação vigente, declaro ESTAR CIENTE do conteúdo deste EXEMPLAR CORRIGIDO elaborado em atenção às sugestões dos membros da comissão Julgadora na sessão de defesa do trabalho, manifestando-me plenamente favorável ao seu encaminhamento e publicação no Portal Digital de Teses da USP.

São Paulo, 19/11/2021

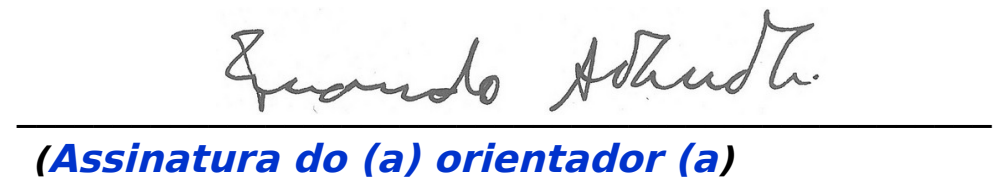


A Alexandre Massella e à memória de Nick Allen 


\section{Agradecimentos}

A Alexandre Massella, pelo estímulo inicial sem o qual esta pesquisa não existiria e pela interlocução ao longo de todos esses anos. A Fernando Pinheiro, pela confiança e generosidade dispensadas na orientação da pesquisa. A Nick Allen (in memoriam), por viabilizar minha estadia em Oxford e pelos encontros semanais no Wolfson College um período ao mesmo tempo de crise e de grande criatividade intelectual para mim. A Willie Watts Miller, pela leitura e discussão dos manuscritos que foi decisiva para o rumo que a pesquisa tomou. A Steven Lukes, que se tornou mais que um orientador, por viabilizar minha estadia em Nova Iorque e por todas as discussões que contribuíram para aquilatar não só o argumento da tese mas, sobretudo, minha identidade como pesquisador.

A Robert Mauss, pela autorização para consultar os arquivos do Fonds Hubert-Mauss; a Christophe Labaune, por todo apoio durante a consulta dos arquivos no Collège de France. A Rafael Benthien, pelo incentivo à pesquisa documental e pela gentileza de compartilhar parte da transcrição da correspondência entre Hubert e Mauss.

Aos comentários, críticas e sugestões realizados em diferentes contextos por Jeffrey Alexander, Leonardo Braga, Marcia Consolim, Tatiane Klein, Paula Montero, Marcello Múscari, Robert Parkin, François Pizarro-Noël, Johannes Schick, Mario Schmidt, Philip Smith, Phillippe Steiner, Edward Tiryakian, Francesco Tomei, Frédéric Vandenberghe, Augusto Ventura, Raquel Weiss e Martin Zillinger.

À Jade Roque, cuja participação na redação e preparação do manuscrito que resultou nesta tese foi, de diversas formas, fundamental.

À Fundação de Amparo à Pesquisa do Estado de São Paulo (FAPESP) pelo financiamento integral da pesquisa que resultou nesta tese (processo $n^{\circ} 2016 / 13339-4$ ). 


\section{Resumo}

LELIS, Romulo. A Elaboração da Sociologia Durkheimiana da Religião: a colaboração entre Émile Durkheim, Henri Hubert e Marcel Mauss. Tese (Doutorado). Faculdade de Filosofia, Letras e Ciências Humanas, Universidade de São Paulo, 2021.

Para Durkheim, a constituição da Sociologia como disciplina científica demanda tanto a colaboração entre especialistas quanto a criação de um arcabouço teórico suficientemente amplo e flexível para orientar as pesquisas. Reconhecendo a desconsideração da dimensão coletiva da sociologia durkheimiana, bem como a ausência de um quadro interpretativo para analisar os vínculos entre os pressupostos gerais e as teorias específicas que eles produziram, a proposta desta pesquisa é investigar a elaboração da sociologia durkheimiana da religião a partir da colaboração entre Durkheim, Hubert e Mauss. Para tanto, selecionamos um conjunto de trabalhos de Durkheim, Hubert e Mauss acerca dos fenômenos religiosos, tomando por referência a colaboração dos autores ao longo da primeira série do Année sociologique (1898-1913). A partir da análise comparativa desses trabalhos, verificou-se as seguintes hipóteses: 1) a transformação da abordagem sociológica da religião de Durkheim pela influência dos trabalhos de Hubert e Mauss; 2) a elaboração por Hubert e Mauss de uma teoria da ação ritual posteriormente incorporada por Durkheim. Concluímos que Hubert e Mauss desenvolveram uma nova abordagem no âmbito da sociologia durkheimiana, centrada nas capacidades afetivas, estéticas e intelectuais da ação ritual de criar ideias e práticas coletivas e, assim, transfigurar as forças sociais em ação.

Palavras-chave: Émile Durkheim; Henri Hubert; Marcel Mauss; Ação Ritual; Estética. 


\begin{abstract}
LELIS, Romulo. The Making of the Durkheimian Sociology of Religion: the collaboration among Émile Durkheim, Henri Hubert, and Marcel Mauss. Doctoral Thesis. Faculdade de Filosofia, Letras e Ciências Humanas, Universidade de São Paulo, 2021.
\end{abstract}

For Durkheim, the constitution of Sociology as a scientific discipline requires both collaboration among experts and creating a theoretical framework sufficiently broad and flexible to guide research. Recognizing the disregard of the collective dimension of the Durkheimian sociology, as well as the absence of an interpretative framework for analyzing the links between the general presuppositions and the specific theories they produced, this study investigates the making of the Durkheimian sociology of religion through the collaboration among Durkheim, Hubert, and Mauss. For this, we selected a set of Durkheim's, Hubert's, and Mauss' studies regarding religious phenomena, taking as reference their collaboration throughout the Année sociologique first series (18981913). From the comparative analysis of these works, we have verified the following hypotheses: 1) the transformation of Durkheim's sociological approach to religion by the influence of Hubert and Mauss' works; 2) Hubert and Mauss' elaboration of a theory of ritual action later incorporated by Durkheim. We conclude that Hubert and Mauss have developed a new approach within the Durkheimian sociology, centered on the aesthetic, affective, and intellectual capabilities of ritual action in creating collective ideas and practices and, thus, transfiguring the social forces at work.

Keywords: Émile Durkheim; Henri Hubert; Marcel Mauss; Ritual Action; Aesthetics. 


\section{Sumário}

Introdução. A sociologia durkheimiana da religião como projeto coletivo

Capítulo 1. Durkheim e os primeiros insights sociológicos sobre a religião: os fenômenos religiosos como regras de conduta obrigatórias

Capítulo 2. Mauss e a emergência da sociologie religieuse:

o drama sagrado e a gênese das ideias e práticas coletivas

Capítulo 3. Hubert e o desenvolvimento da sociologie religieuse: o drama sagrado das festas sazonais à literatura épica

Capítulo 4. Mauss e o desenvolvimento da sociologie religieuse: a lógica da ação ritual e suas transformações

Capítulo 5. Durkheim e o desenvolvimento da sociologie religieuse: de volta à moral sob a égide de uma nova abordagem

Conclusão. Repensando a sociologia durkheimiana da religião 
Ninguém tenta produzir uma ciência sem ter uma ideia por fundamento. No seu desenvolvimento, contudo, raramente o esquema, ou mesmo a definição de ciência que ele oferece no princípio, correspondem à sua ideia; pois esta reside na razão como um germe cujas partes se encontram ainda muito pouco desenvolvidas e quase irreconhecíveis à observação microscópica. Por isso é preciso determinar e definir as ciências, que são todas concebidas desde o ponto de vista de um certo interesse universal, não segundo a descrição que faz delas o seu criador, mas segundo a ideia que, a partir da unidade natural das partes que ele reuniu, pode ser encontrada na própria razão. Pois então se verificará que o criador de uma ciência, e com frequência também os seus seguidores mais tardios, giram em torno de uma ideia que eles mesmos não têm clara, não podendo, portanto, determinar seu conteúdo próprio, sua articulação (unidade sistemática) ou seus limites.

Immanuel Kant, Crítica da Razão Pura

Para o sábio, a ciência não é mais do que um dos meios pelos quais se pode chegar ao conhecimento da verdade. Além dela, existem outros. Acima de todos, a própria razão, que orienta a indagação dos fatos e a descoberta da verdade. Há uma insopitável audácia nesse raciocínio, mas ele é justo: antes da invenção da ciência, a inteligência percorreu outros caminhos, que conduzem igualmente à consciência dos fatos e à evidência da verdade, ainda que de maneira diversa. Por isso, enquanto uns procuravam discutir, com fundamento na razão, a procedência e os limites da explicação cientifica, e outros tentaram estabelecer, com base na libertação da razão pela ciência, novos dogmas filosóficos, os verdadeiros sábios se esforçaram por colocar a investigação científica a serviço completo da razão.

Florestan Fernandes, "Lévy-Bruhl e o Espírito Científico" 


\section{Introdução.}

\section{A sociologia durkheimiana da religião como projeto coletivo}

A constituição da Sociologia teve em Émile Durkheim um articulador chave, cujas posições permanecem pertinentes quando se trata de refletir sobre o desenvolvimento das ciências sociais. Encontramos em Durkheim uma defesa explícita da ciência como trabalho coletivo e cooperativo, que se sustenta não só pela necessidade do acúmulo de descobertas oferecidas à verificação comum, mas também pela formação de um grupo de especialistas de diversas áreas que estejam em contato permanente. "Escola durkheimiana" é a expressão comumente utilizada para designar esse grupo de pesquisadores reunidos em torno do Année sociologique. Concebido e dirigido por Durkheim, o periódico foi publicado pela primeira vez em 1898 e contou, inicialmente, com a colaboração de Marcel Mauss, Henri Hubert, Paul Fauconnet, François Simiand, Célestin Bouglé, Emmanuel Lévy, Gaston Richard, Paul Lapie, Dominique Parodi, Henri Muffang e Albert Milhaud. Ao todo, cerca de 45 pesquisadores participaram de pelo menos algum dos 12 volumes do Année publicados sob a direção de Durkheim. O objetivo da revista era, além de reunir e resenhar material relativo a temáticas específicas - tais como direito, moral, religião e economia -, publicar contribuições originais que pretendiam exemplificar a abordagem propriamente sociológica desses temas. Assim, a constituição da Sociologia como disciplina científica envolveria um trabalho coletivo que requer, além do recrutamento de especialistas, o mapeamento do território da Sociologia e a definição de um quadro de pressupostos e conceitos suficientemente maleáveis e gerais para ganhar o assentimento desses pesquisadores. Falar em escola, portanto, envolve não só a referência histórica a um grupo de pesquisadores que trabalharam juntos em determinado momento, mas, fundamentalmente, o empenho destes num projeto intelectual comum.

Neste estudo, propomos investigar a gênese e o desenvolvimento da sociologia durkheimiana da religião a partir da colaboração entre os membros da equipe do Année. Nesse sentido, pretende-se realizar uma compreensão histórica do desenvolvimento das 
ideias de Durkheim, Hubert e Mauss a respeito dos fenômenos religiosos e avaliar criticamente o valor desse empreendimento para a teoria social. De maneira semelhante à proposta de Steven Lukes em seu estudo sobre Durkheim, esta tese também possui "the primary object of achieving that sympathetic understanding without which no adequate critical assessment is possible. It is a study in intellectual history which is also intended as a contribution to sociological theory" (LUKES, [1973] 1975, p. 1). Nesse âmbito, nossa proposta justifica-se por duas razões. A primeira diz respeito à desconsideração da dimensão coletiva da obra e da proposta de Durkheim: em geral, as interpretações consagradas restringem-se à análise das quatro obras monográficas individuais do autor, negligenciando mais de 15 anos de trabalho em sua maior obra coletiva - o Année. A segunda razão diz respeito ao deficit de ferramentas conceituais para entender os vínculos entre os pressupostos gerais que caracterizam a colaboração entre os pesquisadores do Année e as teorias específicas que estes produziram, concebendo-os como parte de um projeto coletivo de colaboração científica. Nos dois itens subsequentes, apresentamos uma breve síntese do estado da arte sobre os dois problemas que nos interessa conectar: a colaboração intelectual entre os membros da equipe do Année e o desenvolvimento da sociologia durkheimiana da religião.

\section{A colaboração científica entre os membros do Année como problema}

Ainda que seja difícil determinar, o primeiro trabalho de repercussão internacional a respeito das relações intelectuais entre os membros do Année foi o capítulo "French sociology", de Claude Lévi-Strauss, publicado na coletânea Twentieth century sociology, em 1945. No capítulo, Lévi-Strauss apresenta a sociologia francesa do final do século XIX até a década de 1940, tomando por referência a obra de Durkheim e sua equipe para descrever a influência que esses autores exerceram nas ciências sociais da França e de outros países. O cerne do trabalho diz respeito às relações entre Durkheim e Mauss e, apesar de mencionar que Mauss sempre se considerou um seguidor e continuador de Durkheim, Lévi-Strauss argumenta que haveria três diferenças relevantes entre o tio e o sobrinho, quais sejam: i) de pensamento, ii) de método e iii) sobre as relações entre a Sociologia e a Psicologia. Em primeiro lugar, "both minds are different": Durkheim é apresentado como o arquétipo da filosofia francesa da época, cujas conclusões são "toilsomely reached and dogmatically asserted” (LÉVI-STRAUSS, 
1945, p. 526); Mauss, por outro lado, possuiria uma imaginação ousada, seria "a geniuslike feeling of the sociaf stuff urge him to make a highly original use of his unlimited knowledge" (LÉVI-STRAUSS, 1945, p. 527). Em segundo lugar, além dessas diferenças intelectuais, o método de Mauss seria mais satisfatório que o de Durkheim em muitos aspectos: Mauss escaparia da tentação de reconstrução sintética de Durkheim, na qual as sociedades primitivas representariam os estágios iniciais da evolução social. Enquanto Durkheim cairia no equívoco de tirar conclusões universais da análise de um caso privilegiado, Mauss seria mais cuidadoso no uso do método comparativo, selecionando um número pequeno de casos e estudando cada tipo com um todo, sem isolar elementos arbitrariamente e fazendo referência ao complexo cultural a que o fenômeno pertence (LÉVI-STRAUSS, 1945, p. 528). Em terceiro lugar, Mauss teria sido mais consciente que Durkheim a respeito da relação entre os fenômenos sociológicos e psicológicos. Ao contrário da cisão radical de Durkheim entre a Sociologia e a Psicologia, Mauss manteve-se atento contra a possibilidade de bloquear as relações entre as duas ciências (LÉVI-STRAUSS, 1945, p. 529). Nesse sentido, esse esquema de interpretação proposto por Lévi-Strauss contribuiu decisivamente para marcar a cisão do pensamento de Mauss ${ }^{1}$ em relação ao de Durkheim.

A esse respeito, Bruno Karsenti retoma de Lévi-Strauss a interrogação sobre as relações entre Durkheim e Mauss, apresentando argumentos no sentido de uma superação do dogmatismo de Durkheim pelo sobrinho (KARSENTI, 1997). A primeira e principal tese de Karsenti diz respeito à posição da psicologia na sociologia de Durkheim e de Mauss: enquanto Durkheim tenderia a hipostasiar conceitos como o de consciência coletiva e representações coletivas, subordinando toda a psicologia individual ao que ele chama de sociologismo, Mauss superaria essa oposição por meio da noção de simbolismo, apresentando uma investigação sobre o homem concreto em suas três dimensões irredutíveis - biológica, psicológica e social (KARSENTI, 1996 e 1997). A segunda tese de Karsenti, adjacente à primeira, diz respeito à explicação causal dos fatos sociais, definidos por Durkheim pela contrainte que exercem sobre as consciências individuais (KARSENTI, 1996, p. 314). Mauss, segundo Karsenti, teria abandonado essa distinção tão demarcada entre indivíduo e sociedade e, consequentemente, o modelo de explicação causal de Durkheim, privilegiando a análise

1 Sobre a doxa criada por Lévi-Strauss a respeito do pensamento de Mauss, cf. Lygia Sigaud (2002). 
da integração dos elementos sociais com a liberdade de ação individual (KARSENTI, 1997, p. 332-355). Portanto, conforme sugere Karsenti (1998), a ruptura em relação ao modelo epistemológico de Durkheim por Mauss, por meio das noções de fato social total e homem total, promoveria Mauss ao status de segundo fundador da sociologia na França.

Publicada no mesmo período dos trabalhos de Karsenti, a tese de Camille Tarot (1999) também apresenta uma discussão francófona sobre a herança que vai de Durkheim a Lévi-Strauss, assumindo o problema de avaliar a influência dos trabalhos de Mauss nesse ínterim. Circunscrevendo sua análise à avaliação da herança durkheimiana herdada por Mauss, o objetivo de Tarot é determinar a especificidade da contribuição de Mauss, reforçando a sua originalidade e a consequente ruptura com o projeto de Durkheim. Segundo o autor, Mauss partiu do modelo de Durkheim, destinado a tratar os sistemas sociais como realidades naturais; mas, ao contrário do tio, Mauss progrediu em direção a uma antropologia do simbólico (TAROT, 1999, p. 36). Para Tarot, Mauss foi o responsável pela descoberta do grande catalisador do pensamento francês do pós-guerra, a saber, a descoberta da natureza simbólica dos fenômenos sociais, que permitiria superar a dicotomia durkheimiana entre morfologia social e representações coletivas (TAROT, 1999, p. 56). Daí surge uma infinidade de metáforas para distinguir Durkheim e Mauss, tais como: dogmatismo/ecletismo, rigidez/fluidez, usina/atelier, naturalismo/simbolismo. Dessa maneira, as conclusões de Tarot produzem a imagem de um Mauss que progressivamente se libertou das amarras de Durkheim e, depois de sua morte, pôde encontrar seus próprios problemas bem longe dele.

Publicada em seguida à obra de Tarot, a tese de Jean-Christophe Marcel (2001) analisa as metamorfoses do durkheimianismo no período entreguerras, sustentando hipótese de que a posição de Mauss, Simiand, Halbwachs e Bouglé teria sido ambígua em relação à herança de Durkheim. De acordo com o autor, os durkheimianos no período entreguerras produziram, cada um à sua maneira, uma nova psicologia coletiva, interessada nos estados psíquicos coletivos compartilhados pelos indivíduos e, consequentemente, superando a dura oposição entre indivíduo e sociedade de Durkheim (MARCEL, 2001, p. 11). A posição de Mauss em relação à herança durkheimiana é definida por Marcel da seguinte maneira: i) rejeição da oposição radical entre consciência individual e consciência coletiva; ii) um novo programa de pesquisa em 
psicologia social, qual seja, a ciência do homem total; e iii) o desengajamento progressivo de Mauss no empreendimento durkheimiano em favor da consolidação da etnologia (MARCEL, 2001, p. 82-83). Apesar do quadro apresentado por Marcel parecer reforçar o distanciamento de Mauss em relação a Durkheim, em outros momentos o contrário também aparece e a situação de ambiguidade se mantém. Mesmo Mauss sendo considerado pelo autor o mais heterodoxo dos durkheimianos, a aposta na etnologia teria ocorrido como uma maneira de investir e profissionalizar o método etnográfico em proveito da pesquisa sociológica, reafirmando o caráter empírico da sociologia durkheimiana. Além disso, por mais nuançada que pareça a visão de Mauss sobre a psicologia tal qual descrita por Marcel, este reconhece que, para Mauss, os fenômenos psicológicos são considerados apenas as engrenagens e não as causas dos fenômenos sociais (MARCEL, 2001, p. 47).

Em uma perspectiva distinta daquela inaugurada por Lévi-Strauss, o artigo de Terry Clark, "The structure and functions of a research institute: the Année sociologique" (1968), ofereceu outra perspectiva para analisar a escola durkheimiana. O artigo é baseado em sua tese de doutorado, na qual Clark atribui o sucesso da sociologia durkheimiana a três fatores centrais: i) a definição do status de sociólogo pela ascensão de Durkheim no sistema universitário, ii) a criação de um cluster de pesquisadores em torno do Année sociologique e iii) as relações de Durkheim com a comunidade intelectual e com a sociedade em geral (CLARK, 1973, p. 164-165). Embora o Année seja tido por muitos como apenas mais um periódico científico, para Clark o periódico propiciou uma grande inovação dentro do sistema universitário francês e seria mais bem entendido como um instituto de pesquisa, por exercer as funções subsidiárias de "recruitment, training, social integration, and the exercise and legitimation of authority" (ClARK, 1968, p. 78). De acordo com Clark, inspirado pelo instituto de psicologia experimental que conhecera na Alemanha, Durkheim adotou um modelo organizacional semelhante para o Année, regido por dois objetivos: objetividade científica e excelência intelectual. O cluster de jovens pesquisadores recrutados por Durkheim se caracterizaria, segundo Clark, tanto pela "specialization of task through division of labor" (CLARK, 1968, p. 77), quanto pela coesão metodológica em torno de um conjunto de pressupostos comuns. Essa estrutura, no entanto, reforçava a autoridade pessoal de Durkheim e o legitimava no topo da hierarquia do cluster. Com efeito, Durkheim é 
descrito como uma personalidade autoritária e centralizadora, acentuando o papel subordinado dos jovens pesquisadores à autoridade e liderança do mestre (CLARK, 1973, p. 181-185). Caberia aos membros do cluster, portanto, o desenvolvimento das ideias de Durkheim em temas mais específicos e diversos, mas sempre a reforçar o seu domínio intelectual.

$\mathrm{Na}$ esteira de Clark, Yash Nandan almejou produzir uma teoria sistemática das escolas doutrinárias, tomando a escola durkheimiana como o objeto da análise (NANDAN, 1977 e 1980). Para analisar a relação entre Durkheim e os demais pesquisadores da equipe do Année, Nandan propõe a teoria das escolas doutrinárias, baseada em quatro postulados essenciais: i) a existência de um mestre da escola; ii) a existência de doutrinas criadas por esse mestre; iii) a capacidade dessas doutrinas de atraírem discípulos, seguidores e colaboradores; e iv) a dominação dos meios de comunicação para propagação das doutrinas. Nesse sentido, a proposta consiste em "to establish the Durkheimian School as a sui generis reality and as a typical example of the universal category 'doctrinal school'” (NANDAN, 1977, p. xxvii). Apesar da análise ficar aquém de sua pretensão, merece destaque a postura rigorosa do autor para distinguir os tipos de relação entre Durkheim e seus adeptos, dos mais próximos até os que mantiveram uma relação periférica com ele na escola. De acordo com Nandan, haveria uma diferença crucial entre discípulos e colaboradores: a ideia de colaboração científica, usada para descrever o caráter público e democrático da ciência, em que os pesquisadores se relacionam com equidade, "cannot result in the formation and growth of doctrinal schools" (NANDAN, 1980. p. 24), pois na ciência colaborativa não há a relação mestre-discípulo. Com efeito, a escola durkheimiana é concebida em torno de um mestre que impõe sua autoridade a discípulos maleáveis e suscetíveis de aderirem à sua doutrina. Nesses termos, Mauss é apresentado como um dos mais fiéis discípulos de Durkheim e, paradoxalmente, como o seu alter ego (NANDAN, 1977, p. xxxii). A despeito da ambiguidade da posição de Mauss no esquema de Nandan, ele é igualmente enquadrado na relação mestre-discípulo e, portanto, muito distante do modelo ordinário de colaboração científica.

No mesmo período, Edward Tiryakian publicou um longo ensaio de interpretação da matriz durkheimiana na obra organizada por Tom Bottomore e Robert Nisbet, $A$ history of sociological analysis. Ao contrário de Nandan, Tiryakian apresenta a divisão 
do trabalho e colaboração entre pesquisadores para o progresso da ciência como uma preocupação central de Durkheim (TIRYAKIAN, 1978, p. 189). Segundo o autor, houve um elevado grau de colaboração entre os membros da escola, na contra-mão do "individualismo exacerbado" vigente no ambiente universitário francês, de modo que os jovens do Année "not only got their inspiration from Durkheim but who also provided him with important intellectual feedback as he evolved his sociological analysis" (TiRYAKIAN, 1978, p. 213). As relações entre os membros do grupo do Année seriam baseadas na igualdade de condições exteriores e no mérito, princípios de justiça fundamentais da sociedade moderna, contribuindo para um ambiente democrático de produção intelectual (TIRYAKIAN, 1978, p. 223). Baseado nessa visão de colaboração científica, Tiryakian sustenta que a sociologia durkheimiana "amounts to nothing less than devising what the late philosopher of science Imre Lakatos termed 'a scientific research program"” (TIRYAKIAN, 1978, p. 214). A Sociologia como ciência seria, portanto, o elo entre os durkheimianos, tarefa que só poderia ser alcançada por meio da cooperação profissional entre pesquisadores devotados à causa científica.

A consolidação e o marco dos estudos sobre a escola durkheimiana ocorreu em 1979, com a publicação de um número especial da Revue française de sociologie intitulado "Les durkheimiens", organizado por Philippe Besnard. Os trabalhos reunidos consistem em análises e documentos sobre a escola durkheimiana, além de textos inéditos e correspondências dos membros do Année. Em seu ensaio sobre a formação da equipe do Année, mesmo reconhecendo o valor das tímidas tentativas anteriores, Besnard (1979) chama a atenção para a falta de pesquisas sobre as circunstâncias precisas de criação da revista, o recrutamento dos colaboradores e, principalmente, o modo de funcionamento desse empreendimento coletivo. Com a descoberta de novos documentos e da correspondência entre alguns membros do grupo, o principal mérito da iniciativa de Besnard é o de colocar em xeque a imagem comumente divulgada da escola durkheimiana como um clã sociológico, homogêneo no que diz respeito ao recrutamento de membros, que estariam intimamente soldados em torno de Durkheim e de sua doutrina (BESNARD, 1979, p. 7). Com uma pesquisa documental impecável, Besnard demonstra que nunca houve sequer a pretensão de fundar uma escola com uma coesão moral ou ideológica: o único objetivo claro de Durkheim durante o recrutamento dos primeiros membros do Année era o de criar uma colaboração científica profissional 
contra o amadorismo dominante das demais propostas de sociologia. Nesse sentido, a única crença comum a todos os membros é "en la possibilité d'une science sociale, même s'ils ne s'accordent pas sur sa définition et son objet" (BESNARD, 1979, p. 13). As divergências e polêmicas internas eram inúmeras, o que releva o perfil negociador de Durkheim, muito diferente do perfil autoritário e dogmático que lhe é comumente imputado (BESNARD, 1979, p. 16). As pesquisas de Besnard tornaram-se o grande referencial sobre o tema, contribuindo decisivamente para a consolidação dos études durkheimiennes. Além disso, Besnard também ofereceu uma grande contribuição ao debate da relação entre Durkheim e Mauss. "La collaboration entre Durkheim et Mauss", nota publicada em 2003, meses antes de sua morte, resume bem todas as tentativas anteriores de avaliar a relação entre os autores:

Nombreuses sont les gloses comparant Durkheim à Mauss, supputant l'influence de l'oncle sur le neveu ou soulignant les prises de distance de ce dernier. Elles oublient, curieusement, de se pencher sur la collaboration réelle entre les deux auteurs (BESNARD, 2003, p. 319).

Amparado por uma grande pesquisa documental, no intuito de mostrar a grande complexidade da colaboração intelectual entre Durkheim e Mauss, Besnard ataca a esterilidade das tomadas de posição a favor ou contra a filiação intelectual de Mauss a Durkheim sem uma consideração profunda do período em que os dois trabalharam com afinco para realização do Année, o símbolo máximo dessa cooperação (BESNARD, 2003, p. 328). Nesse sentido, Besnard tem o mérito de apresentar o universo de divergências, debates e cooperação da íntima colaboração entre Durkheim e Mauss, sem perder de vista a discussão mais ampla sobre escola durkheimiana e o Année como a instância fundamental dessa colaboração.

Na esteira de Besnard, o trabalho de Laurent Mucchielli (1998 e 2001) tratou do nascimento da sociologia na França entre 1870 e 1915, almejando superar as análises que atribuem o peso decisivo das mudanças tanto às instituições quanto aos indivíduos no caso durkheimiano, tanto aquelas que atribuem o sucesso desse empreendimento coletivo à posição dos colaboradores nas instituições universitárias de prestígio, quanto as que tentam explicar esse sucesso pela liderança carismática e dogmática de Durkheim. Entre esses dois níveis de análise, "existem grupos sociais intermediários cujo peso é capital: são as redes" (MUCCHIELLI, 2001, p. 37). Nesse sentido, o trabalho coletivo em torno no Année seria o fator chave para explicar o sucesso do 
empreendimento durkheimiano frente a seus concorrentes (MUCCHIELLI, 1998). Dentre as razões apresentadas por Mucchielli, a principal a destacar é que Durkheim não pretendia oferecer com o Année uma "tribuna de expressão doutrinal" a qualquer um que apelasse para a sociologia de qualquer maneira. Por meio de um consenso epistemológico mínimo, a saber, a possibilidade da explicação causal em Sociologia, Durkheim logrou formar uma equipe de jovens pesquisadores disposta a colaborar coletivamente em torno de um programa de pesquisa encarnado em um periódico científico (MUCCHIELLI, 2001, p. 47-49).

No espírito das contribuições de Tiryakian e Besnard, Philippe Steiner propôs investigar a relação da sociologia durkheimiana com a economia (2001 e 2005). Argumentando em favor da dimensão coletiva da sociologia durkheimiana, Steiner sustenta que seria impossível conceber a sociologia econômica durkheimiana unicamente a partir de Durkheim, de modo que a contribuição de seus colaboradores do Année para essa questão é incontornável. Com efeito, Steiner afirma que "la réflexion sociologique sur les conditions économiques de la modernité se présente sous la forma de deux programmes de recherches" (STEINER, 2005, p. 13). Oriundo das reflexões seminais de Durkheim em De la division du travail social e encabeçado por François Simiand, o primeiro programa de pesquisa parte de uma crítica do caráter ideológico da ciência econômica e, com o auxílio da estatística, almeja realizar uma sociologia positiva das regras de funcionamento da esfera econômica. Já o segundo programa de pesquisa, esboçado por Durkheim em Les formes élémentaires de la vie religieuse e levado adiante por Mauss, enfatiza o fundamento religioso dos fenômenos econômicos nas sociedades arcaicas e almeja, assim, criticar e repensar o papel das categorias econômicas na sociedade moderna. Segundo Steiner (2011, p. 701-702), inicialmente Simiand manteve distância do segundo programa de pesquisa, tanto por acreditar que havia uma ruptura radical da vida econômica moderna em relação à indígena, quanto porque considerava a pesquisa por fenômenos de origem um resquício da análise ideológica. Todavia, em um segundo momento, Simiand reconhece a relevância da dimensão religiosa e do método genético do segundo programa. Enfim, Steiner (2011, p. 705) sustenta o reencontro dos dois programas de pesquisa durante o entreguerras, conforme expresso nos trabalhos de Mauss, "Essai sur le don", e de Simiand, "La monnaie, réalité sociale". 
Ainda no espírito de Tiryakian e Besnard, em "Leituras da escola durkheimiana" Alexandre Massella (2009) discute a caracterização da tradição durkheimiana e de seus respectivos programas de pesquisa. Nesse sentido, apesar de reconhecer a abundância de tentativas de sistematização de teorias e de dados relativos às circunstâncias históricas e institucionais sobre a escola durkheimiana, Massella identifica um deficit no que diz respeito "às ferramentas conceituais que permitiriam identificar e analisar os elementos que geram e conferem unidade a um corpo de autores ou obras no interior da sociologia" (MASSELLA, 2009, p. 69). Tomando como exemplo o caso das teorias sobre o suicídio de Durkheim e Halbwachs no âmbito do programa de pesquisa em sociologia da moral do grupo, Halbwachs sustenta que sua obra, Les causes de suicide (1930), poderia ser entendida como uma revisão e continuação da obra consagrada de Durkheim. A esse respeito, Massella afirma que Halbwachs mantém o princípio de explicação sociológica tal qual empregado por Durkheim em Le suicide; mas, ao mesmo tempo, Halbwachs introduz modificações mais heterodoxas e difíceis de avaliar, tal como a consideração das motivações individuais na elaboração das tipologias do suicídio. Haveria, para Halbwachs, uma interpretação social dessas motivações, uma vez que elas seriam um efeito da estrutura do grupo manifesto sob a forma individual. Por conseguinte, tal reelaboração de Halbwachs acarretaria uma revisão da noção mesma de suicídio proposta por Durkheim, na medida em que "a intenção de se matar entra como característica da definição" (MASSELlA, 2009, p. 83). Tal posição de Halbwachs demandaria a desconsideração dos sacrifícios como suicídios, bem como a exclusão do suicídio altruísta do conjunto de tipologias originalmente elaboradas por Durkheim.

\section{O problema da gênese e desenvolvimento da sociologia durkheimiana da religião}

A constituição e o desenvolvimento da sociologia da religião por Durkheim e seus colaboradores têm sido objeto de debate por parte da literatura especializada, direta ou indiretamente, desde 1965, quando dois trabalhos seminais vieram a público. Um deles é o artigo de Joseph Sumpf, "Durkheim et le problème de l'étude sociologique de la religion", centrado na famosa 'revelação' de Durkheim acerca do papel preponderante da religião, percebido pelo autor graças à leitura de Robertson Smith. Conforme a declaração de Durkheim em 1907: 
c'est seulement en 1895 que j'eus le sentiment net du rôle capital joué par la religion dans la vie sociale. C'est en cette année que, pour la première fois, je trouvai le moyen d'aborder sociologiquement l'étude de la religion. Ce fut pour moi une révélation. Ce cours de 1895 marque une ligne de démarcation dans le développement de ma pensée, si bien que toutes mes recherches antérieures durent être reprises à nouveaux frais pour être mises en harmonie avec ces vues nouvelles [...] était dû tout entier aux études d'histoire religieuse (...) et notamment à la lecture de Robertson Smith et de son école (DuRKHEIM apud Sumpf, 1965, p. 63 e $67)$.

Ao sustenta que a abordagem sociológica da religião foi efetivamente desenvolvida graças ao contato de Durkheim com os trabalhos de Robertson Smith, Sumpf afirma que a fé comum constitui o elemento essencial da religião para Durkheim, pois "[1]a religion est donc la fois règle et exaltation" (SuMPF, 1965, p. 64). Partindo dessa concepção, o autor aponta que foi a apropriação que Durkheim empreendeu da noção de princípios germinais de Smith que o permitiu "remonter aux formes simples une espèce sociale" (SUMPF, 1965, p. 67). O segundo trabalho, que apareceu no mesmo ano, foi Theories of primitive religion, livro baseado em uma série de conferências proferidas por Edward Evan Evans-Pritchard. No livro, Evans-Pritchard (1965, p. 53-56) designa a proposta de Durkheim como uma teoria estrutural da gênese da religião, tributária das contribuições de Fustel de Coulanges e, principalmente, Robertson Smith. Segundo o autor, Durkheim partiu de três ideias extraídas diretamente de Smith, quais sejam: 1) a religião primitiva como culto totêmico do clã; 2) deus como divinização do próprio clã; e 3) o totemismo como a religião mais elementar. A despeito dessa caracterização geral, Evans-Pritchard observa que, no esquema durkheimiano de análise das cerimônias australianas, a performance dos ritos produziria estados de efervescência coletiva, responsáveis, por sua vez, pela criação das ideias religiosas elementares de alma e de espírito (EvANS-Pritchard, 1965, p. 64-66). Apesar de ser cético quanto a essa explicação das cerimônias australianas, Evans-Pritchard (1965, p. 69-70) reconhece que ela poderia ter sido emprestada do ensaio de Marcel Mauss sobre as variações sazonais na sociedade esquimó.

Em 1973, a publicação da tese de Steven Lukes, Émile Durkheim: his life and work, corrobora a influência de Smith sobre o pensamento de Durkheim acerca da religião. De maneira geral, Lukes caracteriza a dívida de Durkheim com Smith em termos da incorporação dos seguintes elementos: 1) "Smith’s sociological view o f religion"; 2) 
"his conception of its regulative and stimulative functions"; 3) "his contrast between religion as within the communion of the church and magic as outside it and residual"; e 4) "his association of religion and political structure" (LUKES, [1973] 1975, p. 450). Além disso, Lukes distingue duas fases do desenvolvimento da sociologia da religião de Durkheim. A primeira, até 1899, compreende o periodo pré-etnográfico, cujo enfoque era formal e simplista e no qual Durkheim limitou-se a elaborar uma série de hipóteses sobre a natureza da religião e seu papel na vida social. Já a segunda fase, representada por Les formes élémentaires de la vie religieuse (1912), compreende o período etnográfico, de um tratamento da religião mais matizado e complexo graças ao contato com uma massa de material etnográfico. Ainda que muito ligado às críticas de EvansPritchard, Lukes reconhece que a hipótese explicativa de Durkheim de que "religious thought and ritual express and dramatize social relationships is central to a whole and still living tradition of anthropological work" (LUKES, [1973] 1975, p. 483).

Em 1984, o livro de William Pickering, Durkheim's sociology of religion: themes and theories, propõe construir uma classificação sistemática do desenvolvimento do pensamento de Durkheim sobre a religião. Por um lado, Pickering endossa o coro dominante em favor do turning point de Durkheim sobre a religião a partir da "revelação" envolvendo a influência de Robertson Smith (PICKERING, [1984] 2009, p. 55-58). Aqui, destacam-se os seguintes pontos dessa influência: 1) a distinção entre magia e religião, 2) a preeminência do ritual como base de análise; e 3 ) o sacrifício totêmico (PICKERING, [1984] 2009, p. 64-66). Não obstante, Pickering também chamou a atenção para a relevância da efervescência na obra tardia de Durkheim, bem como assinalou que a fonte mais provável dessa noção seria o ensaio de 1906 escrito por Mauss sobre as variações sazonais entre os esquimó (PICKERING, [1984] 2009, p. 382383). Por fim, o autor oferece uma caracterização periodizada das fases de desenvolvimento do pensamento de Durkheim sobre a religião - centrada, ainda, na relação entre Durkheim e Smith:

I. The early period (1880-95): from the time he entered the Ecole Normale Superieure to just before he began to read Robertson Smith;

II. The middle period (1895-1906): from the time of his acceptance of Robertson Smith's ideas to about 1906;

III. The final formulation (1906-17): from the time he delivered the course of lectures in the Sorbonne on the origin of religion to his death (PICKERING, [1984] 2009, p. 50). 
Durante o mesmo período, Robert Alun Jones (1981) também propôs investigar a influência de Robertson Smith em Durkheim. Apesar de tomar como dada a profunda a influência de Robertson Smith, Jones é o primeiro a justificar o crédito dado à "revelação", argumentando que pela escassez de declarações de débito intelectual por parte de Durkheim, a revelação "assumes a prima facie credibility" (JONES, 1981, p. 185). Com efeito, para além das comparações meramente sugestivas, Jones argumenta que o único problema substantivo entre os autores diz respeito à avaliação que Durkheim faz sobre a teoria do sacrifício de Smith, sobretudo em Les formes élémentaires de la vie religieuse (JONES, 1981, p. 186). Em 2005, no entanto, Jones reavalia a posição exposta nos trabalhos anteriores. O autor reconhece que Smith havia se tornado uma figura-chave para compreender o desenvolvimento da sociologia da religião de Durkheim a partir da "revelação" de 1895, mas "what had initially seemed a clear case of direct intellectual influence proved, on further examination, to be unusually complex" (Jones, 2005a, p. 2). Com efeito, Jones constata que nos trabalhos subsequentes não há qualquer evidência de que Durkheim tenha levado a sério algum dos argumentos de Smith. Pelo contrário, até essa época, “Durkheim appeared far more interested in the quite different religious conceptions held by Smith's friend and protégé, Sir James Frazer" (JONES, 2005a, p. 2). Até 1899, Durkheim ainda mantinha um vocabulário muito mais próximo daquele de Frazer para tratar dos fenômenos religiosos, isto é, ligado a discussões sobre tabu, constrangimento, dever e obrigação. A mudança teria ocorrido, conforme aponta Jones, ao longo de um processo de reorientação do foco de Durkheim: "The Frazerian focus on interdictions, prohibition, and taboo that had characterized Durkheim's writing on religion since the mid-1890s", seria substituído por outro, supostamente mais próximo de Smith, "with a focus on those elements that he would later describe as constituting the 'dynamogenic' quality of religion" (JONES, 2005a, p. 212). A dinamogenia, essa força da ação religiosa capaz de elevar o homem acima de si e de fazer com que ele transcenda, constitui, portanto, a concepção central da sociologia da religião de Durkheim ${ }^{2}$, desde sua descoberta do culto positivo em Smith como resposta à interpretação de Frazer acerca dos trabalhos de Spencer e Gillen (JONES, 2005a, p. 229). Todavia, para além dessas sugestões de

2 No Brasil, os trabalhos de Raquel Weiss (2011 e 2013) são certamente os mais representativos desse foco no caráter dinamogênico dos fenômenos religiosos em Durkheim. 
possíveis convergências entre Smith e Durkheim, Jones é forçado a reconhecer que a "revelação" jamais teria ocorrido:

Unfortunately, Durkheim never disclosed the precise nature of this revelation, and in fact, there is no indication whatever, in anything written by Durkheim in the years immediately after 1895, that he had seriously embraced the arguments of Smith's Religion of the Semites (JONES, 2005b, p. 83).

Igualmente cético a respeito da "revelação", Frederico Rosa (2019) sustenta que Smith era, antes, um continuador da psicologia animista das religiões inaugurada por Edward Taylor. Segundo Rosa (2019, p. 369), "les implications psychologiques de Religion of the Semites" são frequentemente escamoteadas pela historiografia que tentou fazer de Smith o prefigurador da sociologia da religião de Durkheim. No entanto, Smith não é mencionado no argumento central de Les formes élémentaires de la vie religieuse, e aparece apenas de passagem no trecho dedicado ao sacrifício australiano, em que é inclusive criticado por Durkheim. Conforme conclui Rosa, Durkheim era sobretudo um crítico do intelectualismo de Smith e da chamada escola britânica, de tal maneira que "[1]a sociologie religieuse allait irréversiblement au delà la psychologie sauvage victorienne" (RosA, 2019, p. 370). Dessa maneira, embora a pesquisa sobre a influência de Smith não tenha chegado a resultados significativos, a suposta "revelação" de Durkheim continua sendo tomada como fato para explicar as mudanças da teoria durkheimiana até hoje, presente em interpretações influentes como as de Alexander (2005), Steiner (2005) e Fournier (2007). Conforme Philip Smith resume em seu recente livro, Durkheim and After: "Regardless of whether scholars stress continuity or change in Durkheim's thought, it is agreed by everyone that William Robertson Smith's [...] study of the Religion of the Semites had a major impact upon him" (SMITH, 2020, p. 48).

A despeito desse aparente consenso, outros autores propuseram uma avaliação crítica dessa "revelação" desde o princípio. Já em 1967, William Stanner sustentara que Durkheim manteve em Les formes élémentaires de la vie religieuse a posição de boa parte de seus escritos anteriores sobre a religião, sem mudanças significativas em sua abordagem ou em seus argumentos, reduzindo "the Australian material to a merely illustrative place in the development of his thought" (STANNER, 1967, p. 220). Dessa maneira, Stanner questiona diretamente o alcance real da dita "revelação" correspondente à influência de Smith, afirmando que até 1897 Durkheim não tinha desenvolvido qualquer resposta sistemática ou final para três questões centrais, quais 
sejam: "the intimate but elusive relations between religion and social order; the place of religion in sociological schema; and the status of religion as determined or determining" (STANNER, 1967, p. 222). Além de identificar a tentativa de Durkheim de se contrapor à Frazer, o autor avalia que a aplicação à religião da chamada teoria do controle social trouxe dificuldades analíticas e conceituais para Durkheim no que diz respeito à lida com o problema das ideias religiosas - questão que só teria uma solução satisfatória em 1907, no curso sobre a origem da vida religiosa (STANNER, 1967, p. 226). Na mesma linha, Ernest Wallwork propôs explorar a análise dos fenômenos religiosos empreendida por Durkheim até 1895 tendo em vista que os intérpretes “have neglected Durkheim's early sociology of religion largely because they have accepted at face value Durkheim's own statement" sobre a influência de Robertson Smith (WALLWORK, 1985, p. 201). Nesses escritos iniciais, os traços constitutivos da religião ao longo de todo esse período são: 1) a experiência de transcendência que o indivíduo sente e que o ultrapassa; e 2) a autoridade do transcendente, que caracteriza a força de obrigação das crenças religiosas. Portanto, "it is not merely the strength of shared beliefs that the young Durkheim emphasizes in characterizing religion, but the feeling of being obligated by psychical forces that "infinitely surpasses the individual"' (WALLWORK, 1985, p. 203). Nesse sentido, a religião contribui para o funcionamento da moral e do direito, na medida em que a função moral mais geral performada pela religião é, justamente, a legitimação das prescrições normativas (WALLWORK, 1985, p. 206). Recentemente, Giovanni Paoletti (2012) também se contrapôs às tentativas de estabelecer a continuidade da sociologia durkheimiana da religião a partir da "revelação" de Durkheim. Paoletti entende que essas tentativas chegariam, no máximo, a resultados parciais sobre o problema, já que carecem de um ponto comum para determinar o sentido preciso desse desenvolvimento. Dessa maneira, confrontando os textos de Durkheim com os de Frazer, Smith e Hartland, Paoletti estabelece a influência de Mauss sobre o ponto de virada ocorrido entre 1898 e 1899, sobretudo no que diz respeito à introdução da dualidade sagrado/profano e às críticas aos trabalhos de Smith e de Frazer (PAOLETTI, 2012, p. 300).

Tal como realizado por Paoletti, esse deslocamento do centro gravitacional do debate - dos antropólogos britânicos para os sociólogos durkheimianos - foi possível graças ao trabalho de François-André Isambert (1976), “L'élaboration de la notion de 
sacré dans l'école durkheimienne". O artigo sustenta que a noção de sagrado adquiriu progressivamente uma importância inexistente nos trabalhos iniciais sobre a religião de Durkheim, sobretudo graças às contribuições de Hubert e Mauss. Há, em Durkheim, duas definições dos fenômenos religiosos: a primeira, encontrada no artigo de 1899, é relativa à forma, isto é, se refere aos fenômenos religiosos como conjunto de crenças e práticas obrigatórias; a outra, datada de 1907, é relativa à noção de sagrado e seu conteúdo. Conforme Isambert, Durkheim duvidara, até 1899, das definiç̧ões de religião em termos de coisas sagradas, ao passo que a partir de 1907 o sagrado não será mais uma maneira de ilustrar o que são os fenômenos religiosos particulares, mas será, a partir daí, produto de uma elaboração teórica (ISAMBERT, 1976, p. 37). Reconhecendo a descontinuidade entre as duas definições, Isambert questiona o lugar-comum da "revelação" sobre a influência de Robertson Smith a partir de 1895 e, contrapondo-se a esta interpretação, enfatiza o caráter progressivo da transformação do pensamento durkheimiano a partir da elaboração da noção de sagrado não somente por Durkheim, mas também por seus colaboradores, Hubert e Mauss, que produziram uma grande quantidade de trabalhos a respeito. Conforme observa Isambert (1976, p. 38):

Le mutisme apparent de Durkheim sur ce point fait contraste, entre 1899 et 1907 avec la prolixité des disciples, comme fait contraste la discrétion de Durkheim en matière de référence Hubert et Mauss par rapport abondance des signes allégeance de ceux-ci à Durkheim.

Assim, para Isambert, a questão central a ser investigada é, precisamente, o intercâmbio intelectual entre os membros do Année. A partir dessa perspectiva, Isambert investiga como o insight inicial de Durkheim acerca do parentesco entre religião, direito e moral, bem como a extensão do domínio do sagrado pela colaboração com Hubert e Mauss colaboram para o desenvolvimento da sociologia durkheimiana em geral (ISAMBERT, 1976, p. 40-41).

A partir do trabalho de Isambert, a investigação da relação de Durkheim com os colaboradores do Année para entender o desenvolvimento da sociologia durkheimiana da religião passou a receber, progressivamente, mais atenção. Nos anos 1990, três trabalhos sem conexão aparente são particularmente ilustrativos dessa nova direção. No primeiro, "Religion and magic: Durkheim and the Année sociologique group", Wouter Belier identifica ao menos duas contribuições fundamentais de Hubert e Mauss para o desenvolvimento da sociologia durkheimiana da religião, a saber: 1) a crítica de Mauss 
e Facuconnet à noção de coerção como signo exterior dos fatos sociais (BELIER, 1995, p. 165); e 2) a distinção entre magia e religião empreendida por Mauss e Hubert (BELIER, 1995, p. 180-181). Assim, conforme conclusão do autor, haveria uma estreita relação entre o desenvolvimento dos trabalhos de Durkheim e aqueles de seus colaboradores: notadamente, a oposição entre sagrado e profano, a distinção entre religião e magia, e a ausência da noção de coerção podem ser todas encontradas em Les formes élémentaires de la vie religieuse (1912), "but no in his earlier works. Before 1912, however, one finds these characteristcs in the works of Hubert and Mauss. The influence of Hubert and Mauss on Durkheim is obvious" (BELIER, 1995, p. 181). No ano seguinte, Stefano Martelli publica o artigo "Mana ou sacré? La contribution de Marcel Mauss à la fondation de la sociologie religieuse" (1996), que sustenta a vasta contribuição de Mauss para a fundação da sociologia durkheimiana da religião. Segundo o autor, a teoria do sagrado apresentada por Durkheim em 1912 é largamente baseada tanto na seleção do material empírico relativo ao sistema totêmico australiano quanto nos desenvolvimentos teóricos realizados por Mauss ao longo de 15 anos como editor do Année, relativos ao domínio dos ritos, dos mitos e da magia. Retomando as contribuições de Besnard, Martelli conclui: “On peut donc dire que la théorie du sacré de Durkheim est le résultat d'un vaste et rigoureux travail collectif, un exemple unique de division de travail scientifique réussi" (MARTELLI, 1996, p. 52). No mesmo ano, a dissertação de Fernando Antonio Pinheiro Filho (1996), também salienta o débito da reflexão tardia de Durkheim sobre a religião em relação aos trabalhos de Hubert e de Mauss. Segundo Pinheiro Filho, Durkheim teria realizado uma verdadeira síntese dos resultados obtidos por seus colaboradores, notadamente pela assimilação da lei do ritmo coletivo, de Mauss, e da virtude operatória do sagrado, de Hubert, para estruturação dos calendários (PinHeIRo FilHo, 1996, p. 79). Com efeito, Hubert e Mauss contribuíram decisivamente para infundir em Durkheim uma nova concepção do sagrado "que perpassa no nível metateórico todo o argumento. De uma primeira construção puramente coercitiva da religião [...] Durkheim passa a uma concepção afetiva" (Pinheiro FiLho, 1996, p. 81). Assim, ao reconhecer que a divisão do trabalho no Année foi orientada por uma concepção coletiva e cooperativa de ciência, Pinheiro Filho conclui que "[a] influência do grupo do Année sobre Durkheim, dando à ciência o crivo 
institucional de produto cumulativo da divisão do trabalho intelectual, não pode ser subestimada" (PinHEIRO FILHO, 1996, p. 82).

Nos anos 2010, foram William Pickering (2012) e Marcel Fournier (2014), que também se distanciaram da "revelação" e se aproximaram da pesquisa a respeito do intercâmbio intelectual interno à equipe do Année sociologique. Em "How compatible were Durkheim and Mauss on matters relating to religion? Some introductory remarks", Pickering propõe analisar as semelhanças e diferenças quanto à definição de religião e de ritual de Mauss e de Durkheim para avaliar quão compatíveis são as concepções dos autores a esse respeito (PICKERING, 2012, p. 6). Quanto à definição dos fenômenos religiosos, Pickering identifica que apesar de haver um acordo quanto à noção de sagrado, Mauss entendia que a noção de mana seria mais abrangente e abarcaria uma gama de fenômenos mais ampla que a noção de sagrado, para ele restrita aos fenômenos obrigatórios, que, por sua vez, se assemelhariam aos fenômenos morais; além disso, Mauss seria cético quanto à possibilidade de uma definição rigorosa de religião, usandoa apenas contextualmente, pela falta de um termo melhor (PICKERING, 2012, p. 13). Com relação ao ritual, Pickering afirma que Mauss "held that ritual was his main interest" e, por essa razão, "Mauss's knowledge of ritual was extensive, far more catholic, than was that of Durkheim" (PICKERING, 2012, p. 15). Tanto que, reconhece Pickering, Mauss contribuiu para o desenvolvimento da ideia de efervescência presente no trabalho de 1912 de Durkheim Nesse sentido, Pickering conclui que além do aproveitamento do conhecimento etnográfico de Mauss por seu tio, podemos verificar na elaboração de Les formes élémentaires de la vie religieuse "the reflection of an ideal combination of two formidable social scientists projecting their slightly different aims and outlooks" (PICKERING, 2012, p. 18). No trabalho mais recente de Marcel Fournier, “Les formes élémentaires comme œuvre collective: les contributions d'Henri Hubert et de Marcel Mauss à la sociologie de la religion tardive d’Émile Durkheim”, o autor estabelece o ano de 1899 - ano da publicação do ensaio sobre sacrifício de Hubert e Mauss - como data de criação de um programa de pesquisa em sociologia da religião, que estabeleceu as bases de uma sociologia do sagrado centrada na análise de um amplo conjunto de crenças e práticas sociais ${ }^{3}$ (FOURNIER, 2014, p. 528-529). Nesse sentido, Fournier apresenta uma série temporal de ensaios e ideias de Mauss e de Hubert que

3 Na mesma época, semelhante tendência é também apontada por Stephan Moebius (2011). 
foram em alguma medida assimiladas por Durkheim para elaboração de sua obra publicada em 1912, enfatizando a centralidade do sagrado, da análise dos rituais e da noção de efervescência. Além dos trabalhos já citados, Fournier sublinha que a cerimônia intichiuma, objeto central de Durkheim em 1912 para investigar a instituição sacrificial, era justamente o objeto de estudo da tese de doutorado inacabada de Mauss sobre a prece. Dessa maneira, "l'étude durkheimienne du rituel est celle qui semble aujourd'hui retenir leplus l'attention des sociologues et qui si actualisation de la pensée durkheimienne il y a en sociologie, c'est par l'idée d'effervescence qu'elle passe" (FOURNIER, 2014, p. 523).

Por fim, o livro de William Watts Miller, A Durkheimian Quest: Solidarity and the Sacred, realiza a tentativa mais compreensiva e abrangente de entender o desenvolvimento da sociologia durkheimiana da religião - centrada, desta vez, na análise do próprio Durkheim. Referindo-se à difundida "revelação" de 1895, Watts Miller questiona se sua aparição em 1907 não seria apenas uma maneira de dramatizar o passado e, desse modo, promover o trabalho de seu novo livro. Por conseguinte, Watts Miller (2012a, p. 76) apresenta uma declaração de Durkheim em uma resenha em que ele diz que a grande "revelação" de seu curso de sociologia da religião era sobre tratar os fenômenos religiosos como coisas, tal qual expresso em Les règles de la méthode sociologique. Assim sendo, 1895 não seria a data chave da mudança do pensamento de Durkheim sobre a religião, mas, como sustenta Watts Miller, esta data corresponderia a 1898, ano de início do Année, isto é, da publicação de ensaios e resenhas que lançaram as bases para a construção de Les formes élémentaires de la vie religieuse (WATTS Miller, 2012a, p. 78). Segundo o autor, no período entre 1898 e 1900, Durkheim encontrava-se em uma crise intelectual, buscando novas abordagens para a religião. Mais precisamente, a crise teve início com a publicação de Spencer e Gillen em 1899, pois foi só então que "Durkheim began to retheorize things in a way that sees times of collective creative effervescence as the key to religion, the sacred and society itself. But the breakthrough that matters isn't evident until his lectures of 1906 and 1907" (WATTS Miller, 2012a, p. 79). Tomando a colaboração entre Durkheim, Hubert e Mauss como o núcleo do Année, Watts Miller afirma que a estratégia inicial dos autores, em uma resenha de Mauss publicada em 1900 sobre o trabalho de Spencer e Gillen, foi a de elogiar o trabalho de campo e criticar a abordagem teórica dos etnógrafos (WATTS 
Miller, 2012a, p. 90). No mesmo sentido, Watts Miller identifica as noções de força impessoal e de variações sazonais de Mauss, bem como a de tempo sagrado para estruturação dos calendários de Hubert, como contribuições fundamentais para o estabelecimento da ideia dos tempos sagrado e profano - a chave para compreender a criação da obra de 1912. Em resumo, a tese interpretativa mais geral de Watts Miller diz respeito à visão ritual da tribo moderna, que esvaziaria a concepção transparente da sociedade moderna previamente estabelecida por Durkheim. Essa tensão entre transparência e transfiguração e entre esclarecimento e mito, é o traço característico da obra de 1912 e o que dá sentido ao problema do sagrado no mundo moderno. Como bem resume o autor:

it involves an inherent ambivalence in The Elemental Forms itself. This still comes with The Division of Labour's commitment to an enlightenment of secular rational transparence. Yet it also comes with a sense that society always and inevitably runs on myth, thanks to energies of the sacred that in the very process of creating a social world act to transfigure it. In other words, it can be seen as fundamentally ambivalent between a sociology of transparence and a sociology of transfiguration (WATTS MiLLER, 2012a, p. xii).

\section{Objetivo, hipóteses e plano da obra}

A revisão de literatura realizada nos dois itens anteriores sintetiza o estado da arte acerca das relações intelectuais entre os membros do Année e, particularmente, do empreendimento da sociologia durkheimiana da religião. No primeiro caso, o balanço bibliográfico apresenta três tendências gerais para enquadrar a relação entre os membros do Année. A primeira tende a reforçar a hierarquia e a dominação exercida por Durkheim sobre os demais pesquisadores, caracterizada pela relação mestre-discípulo: o mestre produz o método e as teorias, cabendo aos discípulos se limitarem a aplicar esse arcabouço aos temas específicos. A segunda tendência reforça as diferenças entre Durkheim e os demais membros do Année, notadamente Mauss, construindo por meio de metáforas uma imagem oposta e, no limite, de ruptura deste último com a proposta de Durkheim. Nesses termos, as duas primeiras tendências reiteram, por razões distintas, o diagnóstico da inexistência de uma colaboração científica entre pesquisadores da escola durkheimiana: ou os membros do Année apenas reproduzem o corpus teórico de Durkheim, ou são independentes e até avessos à sua proposta. Diante desse quadro, alinhamo-nos com a terceira tendência, inaugurada por Tiryakian e 
Besnard, cujos trabalhos demonstram a inconsistência das duas tendências apresentadas: por um lado, nunca houve a pretensão de formar uma escola no sentido estrito, o que é atestado pelas correspondências que relatam as divergências teóricas e metodológicas que os membros do Année sempre mantiveram entre si; por outro lado, também é verdade que sempre houve um acordo mínimo a respeito da aplicação do método científico à análise dos fenômenos sociais e, principalmente, um consenso em torno de uma produção científica cooperativa, mais profissional e, portanto, menos amadora, individualista e proselitista. Tomando o Année como fio condutor para avaliar a divisão do trabalho e a cooperação intelectual entre os membros do grupo, essa terceira corrente de pesquisadores considera, portanto, que os jovens sociólogos do Année não somente foram influenciados por Durkheim, mas também lhe proporcionaram um retorno intelectual relevante para o desenvolvimento de sua análise sociológica.

No segundo caso, a bibliografia revisada propôs avaliar o desenvolvimento da sociologia durkheimiana da religião centrada no próprio pensamento de Durkheim, buscando noções ou ideias de outros autores que teriam sido responsáveis por orientar sua abordagem dos fenômenos religiosos. A esse respeito, a influência de Robertson Smith sobre Durkheim foi certamente a mais explorada e reafirmada - sem que se chegasse, no entanto, a algum resultado sobre a suposta revelação de Durkheim, ocorrida 12 anos antes de sua confissão pública. Em seguida, após um movimento variado de críticas aos limites dessa agenda de pesquisa, a influência dos trabalhos de Hubert e Mauss sobre os de Durkheim passou a ganhar paulatinamente mais relevância. Com efeito, as discussões em torno das noções de sagrado, de força impessoal, de tempo e, especialmente, de efervescência, se tornaram incontornáveis no debate sobre a sociologia durkheimiana da religião. Apesar da maior parte dos autores abordados se limitar a localizar nos textos de Hubert e Mauss essas noções - que estavam inicialmente ausentes dos trabalhos de Durkheim -, tal bibliografia abriu caminho para considerar a elaboração da sociologie religieuse do Année como produto da colaboração de autores como Hubert e Mauss, contribuindo para um resultado final qualitativamente distinto daquele que Durkheim havia estabelecido por si mesmo. Seguindo essas indicações, é preciso enfocar os trabalhos de Hubert e Mauss enquanto editores da seção de sociologie religieuse do Année, que parecem não só fornecer a estrutura de Les formes élémentaires de la vie religieuse, mas da sociologia durkheimiana da religião 
como um todo. Dessa maneira, ao incluir a contribuição da equipe do Année e desfocar a atenção dispensada unilateralmente ao pensamento de Durkheim, a literatura revisada ampliou o escopo da sociologia durkheimiana da religião, incluindo um novo conjunto de obras e de problemas a serem considerados para avaliar sua gênese e desenvolvimento.

O objetivo desta pesquisa será, portanto, o de realizar uma reconstrução sistemática e crítica da gênese e do desenvolvimento da sociologia durkheimiana da religião a partir da colaboração entre Durkheim, Hubert e Mauss. Para tanto, selecionamos um conjunto de trabalhos de Durkheim, Hubert e Mauss acerca dos fenômenos religiosos, tomando por referência a colaboração dos autores ao longo da primeira série do Année sociologique (1898-1913) - período em que Durkheim era o editor do periódico e Hubert e Mauss eram os editores da seção de sociologie religieuse. A esse respeito, o conjunto de trabalhos analisados corresponde a todos os livros, artigos, resenhas e cursos que tratam dos fenômenos religiosos, publicados pelos autores até a eclosão da Primeira Guerra Mundial. Assim, considerando nosso objetivo tal qual o definimos, apresentamos duas hipóteses gerais a serem verificadas no decurso da investigação:

$1^{a}$ hipótese: A transformação da abordagem sociológica da religião de Durkheim pela influência dos trabalhos de Hubert e Mauss;

2a hipótese: A elaboração por Hubert e Mauss de uma teoria da ação ritual posteriormente incorporada por Durkheim.

As hipóteses enunciadas remetem à possibilidade das contribuições dos pesquisadores do Année conformarem a influência ${ }^{4}$ ou causa mais próxima da transformação da abordagem sociológica da religião de Durkheim, transformação esta considerada também o ponto inflexão de seu próprio desenvolvimento intelectual. Tendo em vista que a colaboração científica pressupõe equidade e divisão do trabalho na cooperação entre pesquisadores, é razoável supor uma mútua influência em uma colaboração. No caso da equipe do Année, se está implícito que os pesquisadores do grupo aderiram à proposta geral de Durkheim, o que cabe investigar, portanto, é se o contrário também é verdadeiro, isto é: se os trabalhos de Hubert e Mauss tiveram impacto no

4 Para uma breve e acurada exposição sobre os problemas técnicos envolvidos na atribuição de influência em história intelectual, cf. W. T. Jones (1943). 
desenvolvimento intelectual de Durkheim. Portanto, por meio do teste das hipóteses elaboradas teremos condições de explicar a gênese e desenvolvimento da sociologia da religião durkheimiana no âmbito da divisão do trabalho e especialização da equipe do Année.

Embora sobreposições sejam inevitáveis, os capítulos da tese estão alinhados e divididos de acordo com o desenvolvimento intelectual da sociologia da religião durkheimiana. O primeiro capítulo apresenta os primeiros insights de Durkheim para abordagem dos fenômenos religiosos a partir da sociologie morale et juridique ao longo do período de 1886 a 1899. O segundo capítulo discute a emergência da sociologie religieuse a partir da primeira fase dos trabalhos de Mauss, que vai de 1896 a 1906 e conforma o conjunto de trabalhos responsáveis por produzir uma nova abordagem no interior da sociologia durkheimiana. Já o terceiro capítulo apresenta a contribuição de Hubert para desenvolvimento da sociologie religieuse ao longo de sua colaboração no Année, enfocando o período de 1902 a 1914. O quarto capítulo discute a contribuição de Mauss para o desenvolvimento da sociologie religieuse, enfocando a segunda fase de seus trabalhos, que abrange o período de 1907 a 1914. O quinto capítulo trata da adesão e contribuição de Durkheim para o desenvolvimento da sociologie religieuse, período que corresponde ao intervalo entre 1902 a 1914. Por fim, a conclusão discute os resultados da tese à luz dos problemas e hipóteses apresentados na introdução, propondo uma nova interpretação para o desenvolvimento da sociologia durkheimiana da religião e uma reavaliação crítica de seu legado para as ciências sociais.

\section{Metodologia}

Para o empreendimento proposto por esta pesquisa, investimos em ferramentas analíticas que tratam do desenvolvimento das teorias e dos grandes sistemas teóricos em ciências sociais. Não obstante, a compreensão e interpretação do desenvolvimento teórico das ciências sociais é parte constitutiva do empreendimento da teoria social. Em seu clássico The Structure of Social Action, Talcott Parsons ([1937] 1966) afirma que a investigação de um corpus teórico não consiste no estudo de um grupo delimitado de conceitos e suas inter-relações lógicas, mas de uma teoria de ciência empírica cujos conceitos se referem a algo mais que apenas eles próprios. Para Parsons, há um desenvolvimento imanente ao corpo da teoria social e ao conhecimento do fato 
empírico: nesses termos, a teoria científica não é apenas uma variável dependente dos fatos, mas também uma variável independente em meio ao desenvolvimento científico. A premissa é a de que todo corpo teórico constitui, em maior ou menor grau, um sistema integrado entre suas proposições (PARSONS, [1937] 1966, p. 7). Sendo assim, os sistemas teóricos podem ser representados como um ponto iluminado rodeado de escuridão, de modo que esses sistemas só podem iluminar os fatos por ele mesmo definidos. De maneira semelhante, Jeffrey Alexander (1987), Hans Joas e Wolfgang Knöbl (2009) consideram a dimensão teórica como o elemento central da ciência, responsável por produzir e organizar a realidade: isto é, os fatos, dados e evidências que os cientistas sociais estudam. Segundo Alexander, as teorias são geradas tanto pelos processos não factuais, que precedem o contato científico com o mundo, quanto pela influência que a estrutura desse mundo exerce sobre o pesquisador. Por processos não factuais queremos dizer: os dogmas de uma escola, os processos de socialização intelectual e mesmo a imaginação especulativa do cientista. Esses processos são modificados pelo contato com o mundo real durante a construção das teorias científicas, mas jamais são eliminados. Alexander designa essa parte não empírica da ciência como elementos a priori, cuja existência e cuja circulação entre os cientistas são de responsabilidade das tradições científicas (ALEXANDER, 1987, p. 6). Por conseguinte, as tradições científicas são responsáveis por transmitir, de uma geração a outra, esses elementos a priori que formam o continuum do pensamento científico (ALEXANDER, 1987, p. 7):

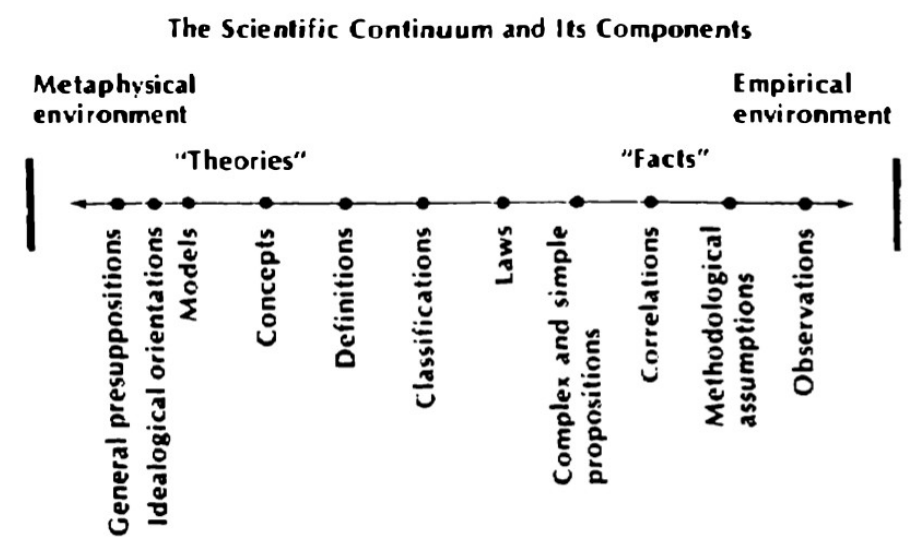

A partir do continuum acima representado, Joas e Knöbl comentam que apesar das observações serem, de fato, mais próximas do ambiente empírico, seria impossível 
reproduzir diretamente a realidade, uma vez que as observações estão vinculadas a pressupostos metodológicos, leis, definições, modelos e, inclusive, pressupostos gerais que estão mais próximos do ambiente metafísico (JOAS; KNÖBL, 2009, p. 9-10). Dessa maneira, não há uma linguagem neutra para descrever os fenômenos observados, pois estes são sempre condicionados - e mesmo constituídos - pelos modelos e pressupostos teóricos que caracterizam as distintas tradições de pesquisa.

Nesse sentido, a discussão sobre o desenvolvimento teórico das ciências sociais remonta, direta ou indiretamente, às contribuições seminais de Thomas Kuhn e Imre Lakatos acerca da natureza coletiva e histórica do desenvolvimento intelectual das ciências. No âmbito da sociologia durkheimiana, vimos que diversos autores chamam a atenção para a discussão a respeito das tradições científicas e seus respectivos programas de pesquisa, propondo interpretar o desenvolvimento da sociologia durkheimiana a partir de uma incorporação seletiva dos instrumentais analíticos desenvolvidos por Kuhn e Lakatos ${ }^{5}$. Considerando a relevância de Kuhn e Lakatos para a reflexão metateórica sobre o desenvolvimento científico, também pretendemos nos servir seletivamente da contribuição de ambos para explicar a mudança científica ocorrida no interior da tradição inaugurada por Durkheim e seus colaboradores. A esse respeito, Kuhn foi responsável por estabelecer que o desenvolvimento intelectual da ciência é realizado por meio da colaboração de cientistas trabalhando numa mesma tradição científica ${ }^{6}$, isto é, compartilhando uma matriz de pressupostos, valores e diretrizes que orientam a resolução de problemas em determinada área. Em sua obra tardia, coligida em The Road Since Structure, Kuhn (2000) passou a dar mais ênfase na estrutura lexical conformada pelas tradições científicas, identificando um segundo padrão de mudança, mais recorrente que as mudanças revolucionárias, a saber: a contínua especialização no interior de determinada tradição, em que há um estreitamento do foco da pesquisa com o objetivo de aprimorar a consistência e a precisão das teorias e os instrumentos para resolução de problemas em determinado nicho de investigação (KUHN, 2000, p. 117-120). Algumas vezes, no entanto, o processo de especialização acarreta a criação de uma nova estrutura lexical, que permite a

5 Além dos trabalhos já mencionados nesta introdução, há, ainda, os de Schmaus (1992) e Tiryakian (1979 e 1986).

6 Para uma avaliação sobre visão social e evolucionária de Kuhn sobre o desenvolvimento científico, cf. K. Brad Wray (2011), Kuhn's Evolutionary Social Epistemology. 
resolução de problemas com os quais a tradição era incapaz de lidar (KUHN, 2000, p. 250-251). Tal mudança teórica acarreta a segmentação da tradição em duas subespecialidades distintas, isto é, em dois modelos coexistentes de resolução de problemas: o novo e o antigo, ambos aplicados a domínios mais restritos. São precisamente esses modelos de resolução de problemas que Lakatos (1970) designa como constituintes da heurística positiva dos programas de pesquisa, isto é, como um conjunto parcialmente articulado de regras e sugestões que indicam o caminho e a maneira de resolver os problemas em determinado domínio. A heurística do programa de pesquisa estabelece, ainda, um modelo ou abordagem inicial sobre os diferentes modos pelos quais as entidades podem interagir, bem como as técnicas experimentais e observacionais a serem empregadas, determinando a escolha dos problemas a serem investigados pelo programa de pesquisa em meio a um mar de anomalias (LAKATOS, 1970, p. 134-137). Dessa maneira, Lakatos designa como força heurística do programa de pesquisa a capacidade e a fertilidade da heurística positiva de criar novas teorias e modelos auxiliares capazes de resolver as anomalias e transformá-las em exemplos de corroboração do programa ${ }^{7}$. Portanto, por meio da articulação dessas concepções de Kuhn e de Lakatos a respeito do desenvolvimento intelectual das ciências pretendemos oferecer, na conclusão desta tese, uma imagem mais adequada do desenvolvimento da sociologia durkheimiana da religião no seio da divisão do trabalho intelectual do Année.

7 Para uma avaliação sobre a centralidade e a fertilidade da noção de heurística no projeto de Lakatos, cf. Peter Urbach (1978) e Olga Kiss (2006). 
Capítulo 1. Durkheim e os primeiros insights sociológicos sobre a religião:
os fenômenos religiosos como regras de conduta obrigatórias

O presente capítulo analisa a abordagem desenvolvida por Durkheim no que diz respeito à investigação da religião e dos fenômenos religiosos entre 1886 e 1899 , período que abrange desde a sua primeira resenha sobre religião até a publicação do artigo sobre a definição dos fenômenos religiosos no segundo volume do Année sociologique. A seleção dos trabalhos analisados compreende todos os artigos, livros, cursos e resenhas publicadas por Durkheim que tratam especificamente dos fenômenos religiosos ao longo desse período. Nesse sentido, contrariando parte da bibliografia precedente, pretendemos sustentar a unidade da abordagem empreendida por Durkheim nesse período, centrada no estudo das regras de conduta obrigatórias por meio da análise das sanções e das interdições, consideradas os signos exteriores que as simbolizam. Nesses termos, Durkheim entende o direito, a moral e a religião como as três grandes forças reguladoras da sociedade, que submetem a conduta e o pensamento à disciplina social e conformam uma comunidade moral. Conforme pretendemos demonstrar, mesmo quando Durkheim introduz modificações relevantes, estas não chegam a contrariar sua orientação dominante e são antes concebidas como um desdobramento da mesma abordagem, isto é, aquela desenvolvida no âmbito da sociologie morale et juridique.

O capítulo está subdividido em cinco partes. Na primeira, apresentamos os primeiros insights de Durkheim acerca da abordagem sociológica dos fenômenos religiosos, presentes em um conjunto de resenhas publicadas durante o período de elaboração de sua tese de doutorado. Na segunda, apresentamos o esquema básico de sua abordagem sociológica para estudar os fenômenos morais, que será estendida para análise da religião primitiva em De la division du travail social (1893). A terceira parte dedica-se à análise do declínio das crenças e práticas tradicionais e a emergência do individualismo como a nova religião da humanidade, tomando como referência Le 
suicide (1897), o curso sobre o socialismo (1896-1897) e alguns artigos-chave. Já a quarta parte analisa o conjunto de artigos e resenhas publicados nos dois primeiros volumes do Année (1898 e 1899), que apresentam uma nova forma de investigar a origem religiosa das regras de conduta jurídicas e morais baseada na análise do sistema de interdições matrimoniais que constitui a religião do clã. Por fim, a quinta parte realiza uma síntese da análise empreendida e seus resultados, destacando os elementos que constituem a abordagem da sociologie morale et juridique para os fenômenos religiosos nesse período.

\subsection{Os primeiros insights para a abordagem sociológica da religião}

Durante o período da elaboração de sua tese de doutorado, Durkheim publicou um conjunto de resenhas que apresentam seus primeiros insights para o desenvolvimento de uma abordagem sociológica da religião, notadamente a partir da crítica às obras de Herbert Spencer, Jean-Marie Guyau e Wilhelm Wundt. Para Durkheim, essas resenhas cumprem o objetivo de avaliar o estado da arte da produção sociológica do período e, assim, trazer à consciência os resultados obtidos pela Sociologia até o momento. A primeira resenha, publicada em 1886, trata do estudo de Herbert Spencer sobre a religião, Ecclesiastical institutions, livro que pretende investigar a evolução da vida religiosa desde as origens até o seu desenvolvimento futuro. Para Spencer, a origem da religião estaria relacionada à origem da concepção humana acerca do sobrenatural, mais especificamente no que diz respeito à noção de espírito humano. A partir do estabelecimento dessa noção cria-se uma ideia de duplicidade humana, em que o espírito aparece como aquele indefinido e eterno, o oposto da duração física de vida e morte do ser. Nesse sentido, o indígena, que teme por tudo que é invisível e misterioso, se imagina vivendo em meio a uma multidão de espíritos errantes e, para se proteger, rende oferendas e sacrifícios a esses espíritos. O culto dos espíritos seria, para Spencer, a primeira e mais primitiva forma de religião, o primeiro germe de todos os desenvolvimentos futuros (DURKHEIM, 1886, p. 62). Durkheim, por sua vez, critica a definição de religião como um conjunto de crenças e práticas relativas a seres sobrenaturais derivados da imaginação, pois ela reduz a complexidade do fenômeno a um conjunto de eventos psicológicos que, por conseguinte, poderiam muito bem resultar no desenvolvimento do sentimento religioso independente de qualquer sociedade 
constituída. Para Durkheim, os símbolos por si mesmos são apenas fenômenos superficiais da consciência coletiva, cuja função "se réduit à constater des faits sans les produire. Elle [la conscience collective] reflète plus ou moins fidèlement ce qui se passe dans les profondeurs de l'organisme [social]" (DURKHEIM, 1886, p. 67). Por essa razão, o símbolo só adquire interesse sociológico na medida em que representa os sentimentos coletivos que estão em sua base. Nesse sentido, Durkheim relaciona os preceitos religiosos com as prescrições morais, levando em consideração que ambos se dirigem aos membros de uma comunidade e geram os mesmos sentimentos de cólera e reprovação quando violados, ou seja, o mesmo tipo de sanção. No mesmo raciocínio está incluído o direito, na medida em que este se define sob um conjunto de ordens imperativas subordinadas à autoridade de uma sanção material. Temos, assim, três tipos de fenômenos cujas relações entre si podem servir para esclarecer uns aos outros. Se a função do direito e da moral consiste em garantir a estabilidade da sociedade e adequála às condições do ambiente, esta deve ser também a função social da religião. $\mathrm{Na}$ citação abaixo, Durkheim apresenta as linhas gerais de sua estratégia para estudar a religião como um fenômeno social intrinsecamente ligado à moral e ao direito:

En effet, quelle différence y a-t-il entre les prescriptions religieuses et les injonctions de la morale ? Elles s'adressent également aux membres d'une même communauté, sont appuyées sur des sanctions parfois identiques, toujours analogues; enfin la violation des unes et des autres soulève dans les consciences les mêmes sentiments de colère et de dégoût. [...] Il est donc impossible d'étudier ces deux ordres de faits en les séparant l'un de l'autre. Ce n'est pas tout. Le droit n'est, lui aussi, qu'un ensemble de commandements, d'impératifs placés sous l'autorité d'une sanction matérielle. Voilà donc trois sortes de phénomènes dont la parenté est manifeste et qui peuvent utilement s'éclairer les uns les autres. Or, le droit et la morale ont pour objet d'assurer l'équilibre de la société, de l'adapter aux conditions ambiantes. Tel doit être aussi le rôle social de la religion. Si elle appartient à la sociologie, c'est en tant qu'elle exerce sur les sociétés cette influence régulatrice. Déterminer en quoi consiste cette influence, la comparer aux autres et l'en distinguer, voilà le problème que doit se poser la science sociale. Mais peu importe que cette action soit exercée au nom du polythéisme, du monothéisme ou du fétichisme; peu importe de savoir comment l'humanité s'est élevée d'un de ces cultes à l'autre, et ce qui se passait dans l'obscure conscience des hommes primitifs. Cela regarde l'histoire. Au reste, quand les institutions sociales que la religion couvre de son autorité viennent à changer, ce n'est pas parce que la conception populaire de la divinité s'est transformée. Tout au contraire, si cette idée se transforme, c'est que les institutions ont changé, et si elles ont changé, c'est que les conditions extérieures ne sont plus les mêmes. Toute 
variation dans le symbole en suppose d'autres dans la chose symbolisée (DURKHEIM, 1886, p. 66-67).

Para Durkheim, o interesse sociológico na religião está em sua função reguladora da sociedade, e não na maneira como a consciência obscura do senso comum tenta explicar e dar sentido às suas crenças e práticas. Assim como o direito e a moral, a religião emana sua força e autoridade do hábito, do costume instituído e é, por essa razão, uma disciplina social. $\mathrm{O}$ que a diferenciaria da moral e do direito é que a religião não se aplicaria somente à conduta, mas também à consciência: ela não só determina nossas ações, mas as nossas ideias e nossos sentimentos. "En définitive, la religion commence avec la foi, c'est-à-dire avec toute croyance acceptée ou subie sans discussion" e sobreviverá enquanto houver homens vivendo juntos, pois "il y aura entre eux quelque foi commune. Ce qu'on ne peut prévoir et ce que l'avenir seul pourra décider, c'est la forme particulière sous laquelle cette foi se symbolisera" (DURKHEIM, 1886, p. 68-69). Para a Sociologia, portanto, importa menos entender o desenvolvimento isolado das ideias dos homens sobre suas crenças, do que entender a correlação entre as instituições e o meio social: ao contrário de Spencer, Durkheim entende que as ideias se transformam de acordo com a mudança das instituições e, consequentemente, mudam as instituições porque as suas condições exteriores também não são as mesmas. Nesses termos, Durkheim entende que o direito, a moral e a religião são as três grandes forças reguladoras da sociedade, e que cabe à Sociologia levar a cabo essa nova frente de pesquisa.

Na resenha seguinte, Durkheim lembra que no número anterior da revista já havia manifestado "le souhait qu'on se mît à étudier la religion comme un phénomène social" (DuRKHEIM, 1887a, p. 299). Em L'irréligion de l'avenir, de Jean-Marie Guyau, a tese principal da obra é de que a religião seria um tipo de sociologia, quer dizer, um exercício explicativo da imaginação humana baseado no raciocínio por analogia, ou, como diz o próprio autor, a religião seria "une explication sociologique universelle à forme mythique" (GUYAU apud Durkheim, 1887a, p. 300). Ainda segundo Guyau, o desenvolvimento da religião ao longo do tempo acarretaria a anomia religiosa, que significaria a supressão da fé dogmática pela disseminação do espírito científico. Nesse sentido, a religião do futuro seria, para Guyau, a irreligião. Além das críticas à especulação de Guyau sobre a gênese das religiões e à sua abordagem intelectualista, a 
principal objeção de Durkheim diz respeito à ignorância do autor sobre "le caractère obligatoire des prescriptions religieusess" pois, na origem, "les idées morales, juridiques et religieuses étaient confondues dans une synthèse un peu confuse dont le caractère cependant était avant tout religieux" (DURKHEIM, 1887a, p. 308). Durkheim não rejeita inteiramente a visão de Guyau, que trata as religiões como cosmologias, mas entende que ela pode ser, no máximo, uma explicação parcial da religião, na medida em que as ideias religiosas não seriam mais que símbolos de sentimentos sociais preexistentes: “pour étudier la religion, il faut pénétrer jusqu'à ces sentiments, en écartant les représentations qui n'en sont que le symbole et l'enveloppe superficielle" (DURKHEIM, 1887a, p. 309; grifo nosso). Dessa forma, Durkheim elabora uma distinção entre dois tipos de sentimentos sociais, quais sejam: o primeiro, individual ou intrassocial, se manifesta no interior da comunidade, nas relações cotidianas e consiste nos sentimentos de estima, de respeito e afeição que podemos sentir por outrem; já o segundo, intersocial, consiste na ligação do indivíduo ao ser social em sua totalidade, manifestando-se preferencialmente nas relações entre sociedades distintas. Se por um lado o sentimento intrassocial deixa intactas a autonomia e a personalidade individual, por outro o sentimento intersocial pressiona o indivíduo a agir enquanto parte de um todo. Assim, os sentimentos intersociais são os únicos que podem "donner naissance à l'idée d'obligation" (DurkheIM, 1887a, p. 309). Para Durkheim, somente o que diz respeito ao interesse coletivo pode ser divinizado e, portanto, seriam "les penchants inter-sociaux qui ont donné naissance au sentiment religieux" (DURKHEIM, 1887a, p. 310). Nesses termos,

[o]utre que cette hypothèse est plus conforme aux faits, elle permet de comprendre pourquoi la physique superstitieuse des religions est obligatoire, tandis que celle des savants ne l'est pas. C'est qu'en effet tout ce qui intéresse la collectivité devient vite une loi impérative ; la société ne laisse pas impunément ses membres faire rien qui soit contraire à l'intérêt social. On s'explique ainsi les analogies et les différences qu'il y a entre les commandements dé la morale et ceux de la religion (DURKHEIM, 1887a, p. 310).

Temos, portanto, a origem da ideia de obrigação e dos sentimentos religiosos naquilo que Durkheim designa provisoriamente por sentimentos intersociais. Nessa origem, dependem da ideia de obrigação os preceitos religiosos, morais e jurídicos. Ainda que a hipótese elaborada por Durkheim seja preliminar, ela já contém o germe do que ele designará em sua tese sobre a divisão do trabalho social por solidariedade mecânica - 
ligada à ideia de obrigação e à união entre preceitos religiosos, morais e jurídicos, subordinação do indivíduo ao todo social - e por solidariedade orgânica - ações de cooperação entre partes autônomas e personalidade individual. Além disso, Durkheim parece dar ainda pouca atenção aos símbolos religiosos, colocando-os em segundo plano em relação à análise correspondente aos sentimentos de solidariedade. Em outra resenha sobre a Revolução Francesa, Durkheim analisa como os princípios de 1789 constituíram uma verdadeira religião, com seus mártires, apóstolos e crentes, de tal modo que acreditaram nesses princípios como atos de fé. Contrapondo-se às tendências que concebiam os ideais da Revolução Francesa como uma doutrina científica, Durkheim afirma que estes constituem fórmulas conscientes de um processo inconsciente: isto é, são "des symboles, mais imparfaits et trompeurs", que "ne peuvent donc refléter que d'une manière très inexacte la réalité sousjacente" (DURKHEIM, 1890, p. 451).

Já em sua longa resenha sobre o desenvolvimento da ciência da moral na Alemanha, fruto de seu período de pesquisa no país e publicada em 1887, nosso interesse dirige-se ao tratamento das noções de obrigação e de constrangimento [contrainte] na investigação empírica dos fenômenos jurídicos, morais e religiosos, principalmente nas obras de Rudolf von Jhering e de Wilhelm Wundt. Após um breve excurso sobre a investigação do direito e da moral pelos juristas na Alemanha, Durkheim detém-se na análise do trabalho de Jhering, cujo cerne da definição de direito diz respeito à noção de constrangimento, este último necessário em termos de assegurar a vida em sociedade e evitar sua desintegração. Apesar dessa necessidade, o direito “n'est pas chose sainte par lui-même ; c'est un moyen en vue d'une fin" (DuRKHEIM, 1887 b, p. 56), qual seja, a manutenção da própria sociedade. Nesses termos, o direito é definido por Jhering como “l'ensemble des conditions d'existence de la société assurées au moyen d'une contrainte extérieure par la force dont dispose l'État" (JHERING apud Durkheim, 1887b, p. 56). Durkheim pontua que Jhering não se restringe a definir essa finalidade do direito, mas busca também as razões que levaram as pessoas a respeitá-lo, pois o direito em si mesmo não é suficiente para garantir a ordem legal. Respeitar as regras apenas pelo medo da repressão do Estado tornaria a sociedade uma prisão. É preciso mais que medo: é preciso uma moral que fundamente as condutas não somente como legais, mas como moralmente justas. E esse é o ponto que interessa a Durkheim, isto é, a relação entre moral, direito e constrangimento: 
La morale a le même objet que le droit elle aussi a pour fonction d'assurer l'ordre social. C'est pourquoi, comme le droit, elle se compose de prescriptions qu'une contrainte au besoin rend obligatoires. [...] Elle n'est autre chose que cette autorité de l'opinion publique à laquelle personne du haut en bas de l'échelle sociale ne peut se soustraire. Parce qu'elle ne se fixe pas en formules trop précises, la morale a quelque chose de plus souple et de plus libre que le droit, et il est nécessaire qu'il en soit ainsi. L'État est un mécanisme trop grossier pour régler les mouvements si complexes du cœur humain. Au contraire, la contrainte morale qu'exerce l'opinion publique ne se laisse arrêter par aucun obstacle ; subtile l'air, elle s'insinue partout (DURKHEIM, 1887b, p. 56-57).

Essa análise mescla elementos do argumento de Jhering com algumas conclusões do próprio Durkheim derivadas dessa leitura. É verdade que Jhering advoga pela necessidade de um constrangimento social para que o Estado e o direito possam de fato exercer suas funções corretamente, pois se dependesse só de interesses individuais e utilitários, muitos arrumariam um jeito de burlar as regras e fugir do constrangimento, o que tornaria a realidade social caótica e o direito ineficiente. Assim, percebemos que o que interessa a Durkheim em Jhering é como se chega à moral a partir do direito. Com efeito, o constrangimento do direito garante a moral mínima para a existência da sociedade, mas não é suficiente para garantir a ordem social, que demandaria um constrangimento mais geral exercido pelas sanções morais. Nessa perspectiva, o trabalho de Wundt contribuiria em investigar o papel privilegiado da religião e dos costumes na origem da moral. Ele argumenta que, no princípio, direito, moral, religião e costumes se fundiam numa síntese indissociável. Além disso, apesar de haver elementos amorais e até imorais na religião, a moral tem "une tendance à s'exprimer sous la forme de l'idéal religieux", pois "a besoin de personnifier son idéal et de lui assurer la garantie d'une sanction", como faz também a religião (DURKHEIM, 1887b, p. 117). Foi com o desenvolvimento histórico que estes domínios se autonomizaram, cabendo ao direito o constrangimento exterior e aos costumes os meios internos de constrangimento. Sendo assim, Wundt identifica duas influências centrais da religião na moralidade: primeiro, nos elementos formais, em que as ideias morais são expressas "partout sous forme de concepts antithétiques auxquels sont attachés des jugements d'approbation et de désapprobation" (DURKHEIM, 1887b, p. 124); segundo, nos elementos materiais, o sentimento de respeito oriundo das crenças religiosas. De acordo com Durkheim, Wundt reconhece o caráter obrigatório que os fins morais assumem, dotados de certa 
autoridade, mas não é capaz de dizer de onde tal autoridade vem e em nome de quem é exercida (DURKHEIM, 1887b, p. 134).

Temos, portanto, que a estratégia de crítica e de definição da religião elaborada por Durkheim identifica-a como uma força regulatória da sociedade, essencialmente ligada à moral e ao direito. Por essa razão, os três tipos de fenômenos demandam uma abordagem centrada na investigação das regras obrigatórias por meio da identificação de sanções morais ou jurídicas exteriores que as simbolizam. As diferenças entre esses fenômenos seriam, para Durkheim, mais caracterizadas em termos de intensidade que de qualidade, tomando os fenômenos religiosos, morais e jurídicos em um contínuo de regras: enquanto umas incidem mais sobre as consciências, como a religião, outras incidem mais sobre as orientações práticas, sejam estas as regras morais ou jurídicas.

\subsection{As crenças e práticas religiosas como regras de conduta sancionadas}

Em artigo de 1895 publicado em La Riforma Sociale, Durkheim trata do estado da Sociologia na França, fazendo menção a seu curso sobre a religião ministrado em 18941895 e jamais publicado. Segundo o autor, a grande inovação de seu curso consistiu em tratar os fenômenos religiosos objetivamente, como coisas:

Avendo trattato della religione nel corso d'un insegnamento, ancora inedito, non abbiamo incominciato per domandare che cosa è l'idea religiosa e il sentimento religioso; ma abbiamo studiato le diverse religioni che sono esistite e che esistono ancora, le abbiamo comparate, messi in rilievo i caratteri comuni, e abbiamo così potuto determinare in che consiste obbiettivamente il fenomeno religioso, ed è sulla cosa così definita che abbiamo portato la nostra analisi (DURKHEIM, 1895b, p. 698).

A inovação no tratamento da religião por Durkheim manifesta no referido curso consiste, apenas, na extensão da análise objetiva de Les règles de la méthode sociologique para determinar os fenômenos religiosos, considerando-os como fatos exteriores e passíveis de análise objetiva. Esse procedimento já havia sido realizado visando garantir a objetividade da investigação dos vínculos morais em sua tese de doutorado, já que "il diritto presenta un grado di determinazione e, per conseguenza, obbijettività che non hanno le massime della morale corrente" e, dessa feita, "è a traverso le loro espressioni giuridiche che abbiamo studiato i fenomini morali" (DURKHEIM, 1895b, p. 698). 
Em De la division du travail social, Durkheim propõe tratar a divisão do trabalho como um fenômeno moral e aplicar-lhe o método das ciências positivas, quer dizer, partir do princípio que os fatos morais são coisas, passíveis de observação, descrição, classificação e sujeição a leis causais. Tal empreendimento implica em reconhecer que os fatos da vida moral consistem em "des règles d'action qui se reconnaissent à certains caractères distirictifs" (DURKHEIM, 1893, p. I). Com efeito, se os fatos morais consistem em regras de conduta obrigatórias que, via de regra, não são imediatamente acessíveis à observação, é necessário identificar os caracteres distintivos e exteriores que permitem ao pesquisador reconhecê-los na realidade. Mais precisamente, conforme prescreve em sua tese latina, é necessário identificar o "signum certum” (DURKHEIM, [1892] 1997, p. 64) que simboliza exteriormente esse conjunto de fenômenos interiores. Para o autor, o caráter obrigatório dos fatos morais pode ser reconhecido a partir da relação necessária entre o fenômeno interno da obrigação e o fenômeno externo da sanção:

comme il est impossible de voir directement ce qui s'y passe, pour savoir de quelle manière les règles de conduite y sont représentées, il faut bien que nous nous référions à quelque fait externe qui reflète cet état intérieur. Or il n'en est pas qui puisse mieux jouer ce rôle que la sanction. Il est impossible en effet que les membres d'une société reconnaissent une règle de conduite comme obligatoire sans réagir contre tout acte qui la viole ; cette réaction est même tellement nécessaire que toute conscience saine l'éprouve idéalement à la seule pensée d'un tel acte. Si donc nous définissons la règle morale par la sanction qui y est attachée, ce n'est pas que nous considérions le sentiment de l'obligation comme un produit de la sanction. Au contraire, c'est parce que celle-ci dérive de celui-là qu'elle peut servir à le symboliser, et comme ce symbole a le grand avantage d'être objectif, accessible à l'observation et même à la mesure, il est de bonne méthode de le préférer à la chose qu'il représente. [...] Or, la réalité d'une obligation n'est certaine que si elle se manifeste par quelque sanction (DURKHEIM, 1893, p. 24-25; grifo nosso).

Assim, Durkheim arregimenta a estratégia para pesquisar fenômenos morais por meio do vínculo que estes mantêm com as formas difusas ou organizadas de sanção, consideradas seus signos exteriores. Nesse sentido, a sanção é o signum certum das regras de conduta obrigatórias, pois simboliza de maneira objetiva a reação necessária da sociedade contra a violação de suas regras morais. Não obstante, tal caracterização exclui todos os atos considerados louváveis, mas facultativos, que se dirigem a ideais morais desejáveis que, no entanto, não se está obrigado a realizar por nenhuma sanção. Segundo Durkheim, “on risque d'affaiblir le sentiment de l'obligation, c'est-à-dire 
l'existence du devoir, en admettant qu'il y a une moralité [...] qu'aucune règle ne détermine" (DURKHEIM, 1893, p. 32, n. 2); portanto, apesar de admiráveis, "ces actes ne sont pas nécessaires, ne sont ajustés à aucune fin vitale, en un mot sont un luxe ; c'est-àdire qu'ils sont du domaine de l'art' (DuRKhEIM, 1893, p. 31; grifo nosso). Nesse sentido, os fenômenos que não consistem em regras imperativas e, por conseguinte, não dizem respeito à esfera do dever, são manifestações facultativas pertencentes ao domínio da estética e não da moral.

Seguindo essa definição, moral e direito constituem duas ordens de fenômenos inseparáveis, distinguíveis apenas pelo tipo de sanção empregada quando da violação de algum deles. A exemplo de objeto de estudo de sua tese doutorado, Durkheim afirma que a solidariedade social é um fenômeno moral e imaterial que, por si só, não se presta à observação. Por essa razão, "il faut donc substituer au fait interne qui nous échappe un fait extérieur qui le symbolise et étudier le premier à travers le second" (DURKHEIM, 1893, p. 66). O direito, assim como a moral, diz respeito a regras de conduta sancionadas; com efeito, aquilo que lhe é essencial e ao mesmo tempo variável são as sanções, que variam segundo sua posição na consciência coletiva e a gravidade dos preceitos. Uma vez que a vida social duradoura tende se a organizar e cristalizar por meio do direito, "pouvons donc être certains de trouver reflétées dans le droit toutes les variétés essentielles de la solidarité sociale" (DURKHEIM, 1893, p. 67). Nesses termos, considerando o seu tipo normal em uma sociedade e em uma determinada fase de desenvolvimento, o fato moral é definido como "toute règle de conduite à laquelle une sanction répressive diffuse est attachée" e, secundariamente, como "toute règle qui, sans présenter nettement ce critère, est pourtant analogue à certaines des règles précédentes, c'est-à-dire sert aux mêmes fins et dépend des mêmes causes" (DURKHEIM, 1893, p. 37-38). Nesse sentido, é graças à análise das sanções que podemos chegar à análise das próprias regras, que constituem a parte central e mesmo a meta da ciência social de Durkheim. Se compararmos a presente definição dos fatos morais àquela dos fatos sociais apresentada por Durkheim em Les règles de la méthode sociologique, é patente a semelhança entre a primeira e a segunda, sendo esta última "toute manière de faire, fixée ou non, susceptible d'exercer sur l'individu une contrainte extérieure" (DURKHEIM, 1895a, p. 19). Sem considerar o que a mudança entre as definições implica, cumpre apenas enfatizar que a relação entre obrigação e constrangimento, regra 
e sanção, desenvolvida para definição do domínio dos fenômenos morais, é estendida por Durkheim para definir todo o domínio dos fenômenos sociais: "Sans doute, nous faisons de la contrainte la caractéristique de tout fait social", mesmo quando "il s'en fasse par la religion une représentation sensible et symbolique" (DURKHEIM, 1895a, p. $150)$.

Em sua tese de doutorado, Durkheim afirma que cada tipo de solidariedade prescreve um determinado tipo de sanção. O vínculo a que corresponde o direito penal é aquele cuja ruptura constitui o crime. É considerado crime todo ato que determina, em qualquer grau, uma reação contra seu autor, ou seja, a pena. Apesar da multiplicidade de tipos e de práticas consideradas crime, para Durkheim a única característica comum a todas é a de serem "des actes universellement réprouvés par les membres de chaque société” (DURKHEIM, 1893, p. 77). Nesse sentido, o esforço do autor concentra-se em caracterizar o direito penal como símbolo do vínculo de solidariedade por similitude. Isso é possível graças a uma característica peculiar do direito penal: ao contrário do direito civil, por exemplo, que prescreve as obrigações a cumprir, o direito penal só edita sanções - ou penas - para determinados crimes cometidos. Com efeito, se as regras violadas passíveis de pena não fazem parte do direito penal, “c'est qu'elles ne sont l'objet d'aucune contestation, c'est que tout le monde en sent l'autorité" (DuRKhEIM, 1893, p. 79). Mas o fato de todos sentirem a autoridade de determinadas regras de conduta não é suficiente para definirmos o que é crime, pois nem toda ofensa a esses sentimentos coletivos é criminosa. Para caracterizar um crime é preciso que esse sentimento coletivo tenha uma certa intensidade média, quer dizer, não basta estar gravado em todas as consciências, é preciso que esteja fortemente gravado. Portanto, atendendo a uma caracterização mais precisa de crime, podemos dizer que "un acte est criminel quand il offense les états forts et définis de la conscience collective" (DURKHEIM, 1893, p. 85). É a consciência coletiva o repositório de toda forma de criminalidade, pois trata-se de uma ofensa a uma autoridade transcendente em relação aos indivíduos. Durkheim argumenta que a característica mais aparente de uma pena é o fato de ela ser uma reação passional, uma expiação levada a cabo pela sociedade contra o criminoso por seu ato. Dessa maneira, "[1]a peine consiste donc essentiellement dans une réaction passionnelle, d'intensité graduée, que la société exerce par l'intermédiaire d'un corps constitué sur ceux de ses membres qui ont violé certaines règles de conduite" 
(DURKHEIM, 1893, p. 102-103). Sua função é reafirmar os valores violados por meio da expiação dos atentados contra a vida coletiva, sendo o direito repressivo o símbolo material de um certo tipo de solidariedade social proveniente de estados comuns a todos os membros de uma sociedade.

De acordo com Durkheim, o conteúdo desses estados fortes da consciência coletiva é justamente o que constitui o domínio da religião. Tomando o judaísmo antigo como modelo de religião primitiva e, consequentemente, o povo hebreu como modelo de sociedade baseada no vínculo por similitude, Durkheim afirma que nessas sociedades o direito repressivo tem por função a regulação dos ritos religiosos. Dessa maneira, o direito primitivo "paraît être tout entier répressif", sendo "[1]es quatre derniers livres du Pentateuque, l'Exode, le Lévitique, les Nombres, le Deutéronome représentent le plus ancien monument de ce genre que nous possédions" (DURKHEIM, 1893, p. 148). Temos, então, uma identidade originária comum entre direito penal e direito religioso, tendo em vista que ambos seriam essencialmente repressivos. Nesses termos, a noção primitiva de sanção religiosa, a expiação, exprime a satisfação concedida a alguma força superior, transcendente, após o descumprimento de uma regra. Por essa razão, o direito penal carregaria sempre uma marca de religiosidade, por reprimir atos que atentam contra seres ou conceitos transcendentes. Do caminho traçado a partir do direito, passando pelo vínculo de solidariedade por similitude e pela consciência comum, chegamos a seguinte caracterização da religião como fenômeno social:

la religion est chose essentiellement sociale. Bien loin qu'elle ne poursuive que des fins individuelles, elle exerce sur l'individu une contrainte de tous les instants. Elle l'oblige à des pratiques qui le gênent, à des sacrifices, petits ou grands, qui lui coûtent. [...] La vie religieuse est toute faite d'abnégation et de désintéressement. Si donc le droit criminel est primitivement un droit religieux, on peut être sûr que les intérêts qu'il sert sont sociaux. Ce sont leurs propres offenses que les dieux vengent par la peine et non celles des particuliers ; or, les offenses contre les dieux sont des offenses contre la société (DURKHEIM, 1893, p. 98).

O trecho acima identifica a religião como uma força capaz de constranger os indivíduos a se conformarem à autoridade transcendente dos deuses, interpretada por Durkheim como uma representação da autoridade da própria sociedade sobre os indivíduos. Durkheim lamenta a falta de uma noção científica de religião, e reconhece a insuficiência de definir o religioso pelas relações dos homens com forças transcendentes ou mesmo sobrenaturais, pois “cette formule ne nous fait pas connaître l'essence du 
phénomène" (DURKHEIM, 1893, p. 183). Na realidade, para elaborar uma noção científica de religião seria necessário tratar o problema pelo mesmo método comparativo aplicado ao crime, o que ainda não havia sido realizado até então. Ainda assim, sustenta a validade de sua conjectura, qual seja, aquela defensora de que a partir de uma forte convicção partilhada por uma comunidade de pessoas adquire-se um caráter religioso que inspira nas consciências o mesmo sentimento de deferência característico das crenças religiosas. No que diz respeito à extensão regulada pela consciência comum na vida social das sociedades com predomínio do vínculo da solidariedade mecânica, a coesão social deriva da religião e carrega consigo sua marca, na medida em que as regras sancionadas pela religião "expriment les similitudes sociales les plus essentielles" (DURKHEIM, 1893, p. 112).

Tal como no judaísmo antigo, as sociedades com predomínio do direito repressivo encerram um forte componente religioso, que regulamenta até os mínimos detalhes da vida privada, produzindo consciências idênticas umas às outras, compostas mais ou menos pelos mesmos elementos. Conforme resume o autor, a torá judaica fornece o exemplo mais primitivo e representativo dessa tendência:

En résumé, à des degrés divers, tout le droit juif, tel que le Pentateuque le fait connaître, est empreint d'un caractère essentiellement répressif. [...] Puisque ce qui fait la nature propre du droit pénal, c'est l'autorité extraordinaire des règles qu'il sanctionne, et que les hommes n'ont jamais connu ni imaginé d'autorité plus haute que celle que le croyant attribue à son Dieu, un droit qui est censé être la parole de Dieu lui-même ne peut manquer d'être essentiellement répressif. Nous avons même pu dire que tout droit pénal est plus ou moins religieux, car ce qui en est l'âme, c'est un sentiment de respect pour une force supérieure à l'homme individuel, pour une puissance, en quelque sorte, transcendante, sous quelque symbole qu'elle se fasse sentir aux consciences, et ce sentiment est aussi à la base de toute religiosité (DURKHEIM, 1893, p. 150-151).

Nas sociedades primitivas, como os hebreus, os costumes seriam cercados de tanto respeito que não se poderia escapar deles sem ser punido. Nesses termos, Durkheim depreende a centralidade do elemento religioso nessas sociedades, estabelecendo que "la religion comprend tout, s'étend à tout. Elle renferme dans un état de mélange confus, outre les croyances proprement religieuses, la morale, le droit, les principes de l'organisation politique et jusqu'à la science" (DURKHEIM, 1893, p. 144). A razão para o predomínio das regras repressivas nas sociedades primitivas é atribuída à extensão e à força da consciência coletiva, que inibe a divisão do trabalho e protege a consciência 
comum de qualquer iniciativa contra as tradições. O sentimento de respeito a uma força superior, que está na base do direito penal, é o mesmo que está na base de toda religiosidade. Nesse sentido, a repressão domina todo o direito nas sociedades primitivas porque a religião penetra em toda a vida jurídica e social, de modo que a origem religiosa do direito penal confirma a característica de sua sanção repressiva, oriunda de delitos contra a fé religiosa, contra os ritos e cerimoniais etc., enquanto delitos praticados contra pessoas eram mais comuns e tolerados. Durkheim estabelece, assim, o estado de dissociação entre o direito e a religião como índice para reconhecer o estágio de desenvolvimento de uma sociedade em relação às demais (DURKHEIM, 1893, p. 153).

Segundo o autor, bastaria olhar os códigos de hoje para perceber que os vínculos oriundos das crenças e sentimentos comuns são muito menos numerosos do que aqueles que resultam da divisão do trabalho. Devemos avaliar minuciosamente essa transição para delinear os elementos que nos interessam. Nesse sentido, cabe demonstrar como as regras que proíbem atos contra sentimentos coletivos no direito foram reduzidas e deram espaço à ampliação de direitos com referência a sentimentos relativos ao indivíduo, concomitantemente ao desenvolvimento da personalidade individual. Um bom exemplo é a regulamentação da vida doméstica, que perdeu todo e qualquer caráter penal. Se antes as punições por infringir as regras domésticas acarretavam na maior parte dos casos nos quais eram aplicadas sanções repressivas, ocorre que os sentimentos domésticos saíram paulatinamente da consciência coletiva para ter seu lugar na esfera do direito restitutivo. Com a mudança dos sentimentos domésticos para fora da consciência comum, também o direito doméstico migrou da esfera penal para a esfera restitutiva. O fator fundamental dessa transição é, contudo, o desaparecimento dos crimes religiosos do direito penal, efeito da saída dos sentimentos religiosos típicos dos estados fortes e definidos da consciência coletiva. A religião, que esteve presente na gênese do direito penal, também teve de mudar de caráter com o desenvolvimento da divisão do trabalho. Se, na origem, há uma identidade comum entre religiosidade e consciência coletiva, sinonímia entre religioso e social, as funções políticas, econômicas, científicas e mesmo cotidianas se emanciparam da religião e passaram a ter um caráter temporal mais acentuado. $\mathrm{O}$ divino, que antes permeava todas as relações humanas, retira-se progressivamente destas relações e exerce uma ação cada vez mais 
distante, geral e indeterminada. Tal mudança compreende, portanto, não somente as transformações dos sentimentos que caracterizam o direito penal, mas também o caráter da consciência comum e de suas representações. Assim, temos que a religião compreende duas dimensões: uma sensível e relativa ao direito, e outra intelectual, relativa às representações e ideias, de modo que a mesma lei se aplica tanto aos elementos de representação quanto aos elementos afetivos: “A travers le droit pénal, nous ne pouvons atteindre que des phénomènes de sensibilité, tandis que la religion comprend, outre des sentiments, des idées el des doctrines" (DURKHEIM, 1893, p. 184). Dessa forma, no lugar de todos esses deslocamentos de sentimentos e representações constituintes da consciência comum para fora, Durkheim vê no desenvolvimento da personalidade individual uma nova espécie de religião, uma fé comum centrada no indivíduo:

elle [la conscience commune] consiste de plus en plus en des manières de penser et de sentir très générales et très indéterminées, qui laissent la place libre à une multitude croissante de dissidences individuelles. Il y a bien un endroit où elle s'est affermie et précisée, c'est celui par où elle regarde l'individu. A mesure que toutes les autres croyances et toutes les autres pratiques prennent un caractère de moins en moins religieux, l'individu devient l'objet d'une sorte de religion. Nous avons pour la dignité de la personne un culte qui, comme tout culte fort, a déjà ses superstitions. C'est donc bien, si l'on veut, une foi commune (DURKHEIM, 1893, p. 187).

Tem-se, assim, as condições de emergência da personalidade individual. Com o aumento da densidade e volume social, as regras jurídicas e morais se emancipam das particulares e se generalizam, perdem sua precisão e passam a regular apenas formas mais gerais de conduta. A religião, tida como forma eminente da consciência comum, "absorbe primitivement toutes les fonctions représentatives avec les fonctions pratiques" (DURKHEIM, 1893, p. 316), de tal modo que o florescimento do livre exame da reflexão depende do enfraquecimento da fé comum. Todavia, essa tendência de generalização manifesta-se igualmente na transcendência do elemento mais essencial da consciência comum, qual seja, a noção de divindade: ela também se universaliza, tornase "plus générale et plus abstraite; car elle est formée non de sensations, comme dans le principe, mais d'idées" (DURKHEIM, 1893, p. 320). Esse desenvolvimento implica em outra consequência importante: o processo de racionalização inerente à civilização. Diz Durkheim que "seul est rationnel qui est universel” (DuRKHEIM, 1893, p. 321) e, por 
conseguinte, quanto mais a consciência comum está próxima das particularidades locais, menos inteligível ela é. O declínio do tipo segmentário, da solidariedade mecânica e das crenças tradicionais abre espaço para a maior divisão do trabalho, para o desenvolvimento da solidariedade orgânica e da liberdade individual.

Nesse sentido, é possível observar que o desenvolvimento macro-histórico dos tipos sociais e a progressiva modificação do vínculo social predominante são acompanhados, paralelamente, pelos diferentes estágios da evolução do culto religioso. Em uma passagem, retirada da primeira edição de 1893, que foi substancialmente modificada na segunda edição, de 1902, sobre a evolução da noção de divindade, Durkheim sugere as linhas gerais desse desenvolvimento religioso concomitante às mudanças na estrutura social:

A l'origine, les dieux ne sont pas distincts de l'univers ; mais tous les êtres naturels qui sont susceptibles d'avoir quelque influence sur la vie sociale, d'éveiller les craintes ou les espérances collectives, sont divinisés. Ce caractère ne leur est d'ailleurs pas communiqué du dehors, il leur est intrinsèque. Ils ne sont pas divins parce qu'un dieu habite en eux; ils sont eux-mêmes les dieux. C'est à ce stade de l'évolution religieuse que l'on a donné le nom de naturisme. Mais peu à peu les dieux se détachent des choses avec lesquelles ils se confondaient. Ils deviennent des esprits qui, s'ils résident ici ou là de préférence, existent cependant en dehors des formes concrètes sous lesquelles ils s'incarnent ; c'est le règne de l'animisme. Peu importe qu'ils soient multiples ou qu'ils aient été, comme chez les Juifs, ramenés à l'unité ; dans un cas comme dans l'autre, le degré d'immanence est le même. S'ils sont en partie séparés des choses, ils sont toujours dans l'espace. Ils restent donc tout près de nous, constamment mêlés à notre vie. Le polythéisme gréco-latin, qui est une forme plus élevée et mieux organisée de l'animisme, marque un progrès nouveau dans le sens do la transcendance. La résidence des dieux devient plus nettement distincte de celles des hommes. Retirés sur les hauteurs mystérieuses de l'Olympe ou dans les profondeurs de la terre, ils n'interviennent plus personnellement dans les affaires humaines que d'une manière assez intermittente. Enfin, avec le christianisme, Dieu sort définitivement de l'espace ; son royaume n'est plus de ce monde ; la dissociation entre la nature et le divin est même si complète qu'elle dégénère en antagonisme. [...] Le Dieu de l'humanité a nécessairement moins de compréhension que ceux de la cité ou du clan (DURKHEIM, 1893, p. 319-320).

O trecho citado trata de como as crenças religiosas se tornam cada vez mais transcendentes e, consequentemente, cada vez menos diretamente ligadas à morfologia social. Tal desenvolvimento do culto - naturismo, animismo, politeísmo, cristianismo e o Deus da humanidade - corresponderia, ainda que sem exatidão, ao desenvolvimento 
histórico dos tipos sociais, a saber: desde as sociedades segmentares, como a horda, o clã e a associação de clãs, até as sociedades com domínio progressivo da divisão do trabalho, como a cidade antiga greco-romana, a sociedade cristã medieval e a sociedade industrial moderna. A partir dessa correlação, é possível sustentar que a religião também muda de acordo com o processo de diferenciação estrutural e funcional das sociedades ${ }^{1}$. Todavia, não é possível estabelecer uma correspondência exata entre crenças religiosas e estrutura social, levando em consideração que nem o próprio Durkheim estabeleceu diretamente a precisa correspondência entre cada estágio da evolução do culto religioso e cada tipo de estrutura social. E há uma razão para isso: precisamente porque a religião não é o objeto central da pesquisa e só aparece subsidiariamente à análise da solidariedade social, que é observada, por sua vez, a partir da análise dos códigos jurídicos. A esse respeito, Durkheim estabelece explicitamente como a variação dos códigos jurídicos simboliza a variação do vínculo social em cada um dos seis tipos sociais correspondentes. Já a evolução do culto só é mencionada posteriormente, entre os fatores secundários, no capítulo relativo às causas da indeterminação progressiva da consciência comum e, ainda assim, em apenas um parágrafo, cujas considerações exprimidas acerca da evolução do culto primitivo são de segunda mão, retiradas do compêndio de história das religiões de Albert Réville².

\subsection{Do declínio das crenças e práticas tradicionais à religião da humanidade}

Sendo aquilo que constitui a preocupação mais geral em De la division du travail social, o declínio dos costumes tradicionais e o aumento da reflexividade abrem espaço para uma mudança estrutural dos próprios costumes e a consequente emergência da personalidade individual como o novo valor da consciência comum. A ideia de ser uma pessoa torna-se uma regra obrigatória, que ninguém ousa contestar. Todavia, a mudança

1 É o que aponta corretamente Wallwork (1985, p. 207); mas para daí estabelecer uma correlação entre culto religioso e tipo social que não se sustenta por dois equívocos. O primeiro é que o autor utiliza uma tradução americana que se baseia na segunda edição do livro de 1902, e não na primeira, de 1893, como parece crer. Na reedição de 1902, Durkheim introduz modificações sobre a religião, como a noção de sagrado e de culto totêmico, apresentadas por Wallwork como se fossem de 1893 . O segundo equívoco, decorrente do primeiro, é que sua tipologia da evolução do culto religioso confunde os primeiros estágios do culto e chega mesmo a produzir uma distinção artificial para poder criar uma correspondência perfeita entre os tipos religiosos e os seis tipos sociais (cf. WALLWORK, 1985, p. 206-210).

2 Albert Réville, teólogo protestante liberal, foi o primeiro editor da Revue de l'histoire des religions e o primeiro presidente da seção de ciências da religião da École Pratique des Hautes Études. 
estrutural na ordem moral por meio da divisão do trabalho influencia o tipo de adesão dos indivíduos às normas, que perdem pouco a pouco seu caráter constrangedor e abrem espaço para a adesão racional pelo livre pensar. Em razão dessa mudança estrutural na ordem moral propiciada pela divisão do trabalho, Durkheim passa a se preocupar com as patologias oriundas do declínio das crenças tradicionais na sociedade moderna em Le suicide. Nessa obra, ele investiga o grau de influência das confissões religiosas sobre o suicídio, notadamente a partir das confissões judaica e cristã - esta última subdividida entre católicos, anglicanos e protestantes. A regra de análise diz respeito à capacidade maior ou menor de integração moral de cada confissão religiosa, de modo que quanto menor a integração moral, maior a disposição para o suicídio. Nesse sentido, o judaísmo seria a religião com a menor taxa de suicídio, seguido de perto pelos católicos, anglicanos e, em último lugar, os protestantes, confissão com a maior taxa de suicídio. No caso dos judeus, Durkheim entende que estes configuram-se na maioria dos casos como minoria religiosa e, consequentemente, por terem de lutar contra a hostilidade alheia, se submetem à disciplina mais rigorosa e à maior moralidade: "Pour justifier la tolérance, toujours précaire, qui leur est accordée, elles sont tenues à plus de moralité" (DURKHEIM, 1897a, p. 154). Já a diferença entre as taxas de suicídio referentes aos grupos de católicos e protestantes não pode ser explicada pela relação numérica em determinada região e a justificativa deve, segundo o autor, ser buscada na própria natureza dos dois sistemas religiosos. Em primeiro lugar, é preciso notar que o suicídio é severamente proibido e essa proibição possui o mesmo caráter divino em ambas as confissões, ou seja, constitui um crime religioso. Sendo assim, se o suicídio é proibido tanto para católicos quanto para protestantes, não podemos encontrar na própria proibição a divergência que favorece o suicídio entre os protestantes. Qual seria, então, a divergência relevante para explicar essa diferença entre as taxas de suicídio relativas aos dois grupos? Durkheim argumenta que a diferença essencial entre os dois sistemas religiosos é o fato de que o protestantismo admite o livre exame em maior grau que o catolicismo. Dessa maneira, "le catholique reçoit sa foi toute faite", pois a doutrina católica é constituída de um sistema hierárquico de autoridade que pretende "trendre la tradition invariable" ou, ao menos, dificultar a mudança (DURKHEIM, 1897a, p. 157). Em contrapartida, no protestantismo o fiel se torna mais autor da sua crença, uma vez que nenhuma interpretação da Bíblia lhe é necessariamente imposta e o sacerdote não 
possui qualquer autoridade especial para estabelecer o dogma para o fiel. A prova dessa liberdade de exame protestante é a proliferação de seitas de toda sorte, que contrasta com a indivisibilidade da Igreja católica.

No entanto, o livre exame que anima o protestantismo não é senão o efeito de uma outra causa, essa sim capaz de explicar a diferença essencial em relação ao catolicismo, a saber, "l'ébranlement des croyances traditionnelles" (DURKHEIM, 1897a, p. 157). O protestantismo se constituiu não como um novo sistema de crenças dotado daquela mesma autoridade do catolicismo, mas como um cisma da tradição católica. Ademais, a Igreja da Inglaterra, cujos fiéis são conhecidos como anglicanos, é o fato que serve para corroborar essa explicação. Em termos de suicídio, os anglicanos ocupam um lugar intermediário entre católicos e protestantes. Para Durkheim, essa posição intermediária nas taxas de suicídio seria um reflexo da posição também intermediária dos anglicanos em relação à integração moral, que pode ser verificada principalmente: 1) pelo número de crenças e práticas comuns e obrigatórias e 2) pela organização hierárquica do clero, que faz dos anglicanos uma sociedade religiosa mais solidamente constituída e, nesse sentido, mais próxima da organização eclesiástica e doutrinal da Igreja católica que das demais seitas protestantes. Dessa perspectiva, temos um contraste entre o tradicionalismo católico e o individualismo protestante, que remonta à mudança de papel desempenhado pela religião na vida social: deixando de legislar até sobre os detalhes da vida pessoal, as religiões tradicionais possuem um espaço de autoridade que é cada vez mais limitado. Conforme Durkheim, quanto mais crenças possuem um caráter religioso, e quanto mais práticas a ele são associadas, "plus aussi l'idée de Dieu est présente à tous les détails de l'existence et fait converger vers un seul et même but les volontés individuelles"; e, inversamente, "plus un groupe confessionnel abandonne au jugement des particuliers, plus il est absent de leur vie, moins il a de cohésion et de vitalité" (DURKHEIM, 1897a, p. 159). Dessa maneira, o caráter religioso opõe-se ao livre exame, pois o primeiro é definido pela autoridade que possui sobre as consciências individuais. O protestantismo possui uma taxa maior de suicídio por ser, dentre as religiões analisadas, aquela que é menos coesa e com menor capacidade de integração moral.

O enfraquecimento das crenças tradicionais ou do caráter religioso diz respeito, sobretudo, ao enfraquecimento da fé comum como elemento de integração e de coesão 
social. É preciso notar que Durkheim não menciona nenhum elemento ou conteúdo de alguma confissão religiosa, mas antes o caráter religioso que é encarnado por um tipo de vínculo social, que por sua vez é compartilhado por diversos grupos sociais além daqueles de natureza especificamente religiosa. Nesse sentido, não é por causa de qualquer "nature spéciale des sentiments religieux que la religion doit son efficacité, puisque les sociétés domestiques et les sociétés politiques, quand elles sont fortement intégrées, produisent les mêmes effets" (DURKHEIM, 1897a, p. 222). O cerne do argumento de Durkheim, portanto, está na capacidade da religião de ser uma sociedade, no sentido de constituir-se numa comunidade moral. Conforme sua conclusão:

Ce n'est donc pas à la nature spéciale des conceptions religieuses qu'est due l'influence bienfaisante de la religion. Si elle protège l'homme contre le désir de se détruire, ce n'est pas parce qu'elle lui prêche, avec des arguments sui generis, le respect de sa personne ; c'est parce qu'elle est une société. Ce qui constitue cette société, c'est l'existence d'un certain nombre de croyances et de pratiques communes à tous les fidèles, traditionnelles et, par suite, obligatoires. Plus ces états collectifs sont nombreux et forts, plus la communauté religieuse est fortement intégrée ; plus aussi elle a de vertu préservatrice. Le détail des dogmes et des rites est secondaire (DURKHEIM, 1897a, p. 173; grifo nosso).

A conclusão de Durkheim evidencia a ênfase nos aspectos semelhantes que os fenômenos religiosos têm com fenômenos morais, notadamente o tipo de vínculo moral característico das sociedades com predomínio da solidariedade por similitude, em detrimento dos elementos que as crenças e práticas religiosas teriam de específico e distintivo.

Nesses termos, ao tratar da natureza social ou individual relativa à origem $d a$ religião, Durkheim afirma que a religião é "en définitive, le système de symboles par lesquels la société prend conscience d'elle-même ; c'est la manière de penser propre à l'être collectif' (DURKHEIM, 1897a, p. 352). Assim, a vida social também possui seu elemento "psychique", na medida em que ela é "essentiellement faite de représentations" (DURKHEIM, 1897a, p. 352), mas de natureza absolutamente distinta das representações individuais. E por essa mesma razão, a explicação da natureza social dos símbolos religiosos não pretende, mais uma vez, enfatizar nenhum atributo especificamente religioso; pelo contrário, sobre a irredutível heterogeneidade do social e do individual, Durkheim afirma que "les observations précédentes s'appliquent, non seulement à la religion, mais au droit, à la morale, aux modes, aux institutions 
politiques, [...] en un mot à toutes les formes de la vie collective" (DURKHEIM, 1897a, p. 353). Para além das querelas relativas à psicologia, no entanto, há outra necessidade de afirmar que a religião consiste em um sistema de símbolos, que remonta ao mesmo problema da moralidade, mais especificamente à questão da relação entre o tipo social e o tipo médio. Segundo Durkheim, o homem médio possui, em geral, uma moralidade medíocre, de tal maneira que as máximas morais nele gravadas estão longe de possuir a força e a autoridade que possuem tomando o conjunto da sociedade. Perguntando-se, então, de onde provêm os "préceptes élevés et nettement impératifs" que a sociedade impõe a seus membros, Durkheim sustenta (1897a, p. 359) que não é por acaso que as religiões "considèrent la morale comme ne pouvant avoir toute sa réalité qu'en Dieu", pois é essa a maneira como o senso comum ou "l'imagination populaire" explica a existência das máximas morais: por meio de símbolos imperativos como a ideia de deus. É essa, portanto, "l'origine de toutes ces idées de transcendance qui sont à la base des religions et des morales; car l'obligation morale est inexplicable autrement" (DURKHEIM, 1897a, p. 381). Assim, a transcendência da noção de deus é o fundamento da obrigação moral, e tal fato permite compreender melhor o exercício da disciplina social pela religião:

Si d'assez nombreux écrivains ont vu dans la religion l'unique remède au mal, c'est qu'ils se sont mépris sur les origines de son pouvoir. Ils la font tenir presque tout entière dans un certain nombre de hautes pensées et de nobles maximes dont le rationalisme, en somme, pourrait s'accommoder et qu'il suffirait, pensent-ils, de fixer dans le cœur et dans l'esprit des hommes pour prévenir les défaillances. Mais c'est se tromper et sur ce qui fait l'essence de la religion et surtout sur les causes de l'immunité, qu'elle a parfois conférée contre le suicide. Ce privilège, en effet, ne lui venait pas de ce qu'elle entretenait chez l'homme je ne sais quel vague sentiment d'un au delà plus ou moins mystérieux, mais de la forte et minutieuse discipline à laquelle elle soumettait la conduite et la pensée. Quand elle n'est plus qu'un idéalisme symbolique, qu'une philosophie traditionnelle, mais, discutable et plus ou moins étrangère à nos occupations quotidiennes, il est difficile qu'elle ait sur nous beaucoup d'influence (DURKHEIM, 1897a, p. 431; grifo nosso).

Nesses termos, as religiões só podem disciplinar ou socializar os indivíduos na medida em que lhe retiram a possibilidade do livre exame. Essa grande capacidade reguladora é um traço característico das religiões mais arcaicas, como o judaísmo, que mantém semelhanças com as religiões primitivas. Símbolos que não estão conectados e podem ou não servir de fundamento para máximas morais possuem um poder limitado sobre os 
indivíduos. O privilégio característico da religião para Durkheim é, portanto, o de submeter a conduta e o pensamento a uma disciplina forte.

Com o declínio das religiões e crenças tradicionais como forças regulatórias na sociedade moderna, Durkheim avalia a proposta de Saint-Simon de uma nova religião da humanidade em seu curso sobre o socialismo, ministrado em 1895-1896. Durkheim afirma que o expoente do socialismo francês concebeu a religião como um eminente sistema de ideias, servindo de parâmetro para a construção de sua filosofia positiva e, consequentemente, culminando na proposta de renovação do cristianismo como um dos elementos de sua doutrina. Nesse sentido, Saint-Simon atribui à religião um papel essencial no desenvolvimento do espírito humano, no que diz respeito à significação cada vez mais importante que a religião atribui aos sentimentos morais em suas doutrinas. Dessa maneira, Saint-Simon sublinha os "grands progrès que le christianisme fit faire aux idées morales", como a subordinação dos "affections patriotiques à l'amour général de l'humanité" (DuRKHEIM, 1928, p. 255). Para Saint-Simon, o socialismo precisaria, além do desenvolvimento de uma nova forma de organização da vida econômica, de um corpo de crenças comuns que faça da sociedade uma unidade moral; e essa comunhão espiritual só poderia ser assegurada por uma religião comum da humanidade. Nesse contexto, a nova religião tem a função de combater o particularismo intelectual e recuperar a fé comum, abalada desde que o cristianismo perdeu sua influência. A nova religião deve, portanto, reagir contra a tendência à dispersão da sociedade moderna e "donner aux hommes le sentiment de l'unité du monde, mais en tenant compte des résultats auxquels sont arrivées les sciences particulières" (DURKHEIM, 1928, p. 266). De acordo com Saint-Simon, portanto, a moral é parte central da nova religião, e os ritos e os dogmas não serão mais que acessórios superficiais e dispensáveis. Ao reclamar essa direção para a evolução religiosa, Durkheim corrobora a interpretação de Saint-Simon sobre o caráter cada vez menos ritualístico e mitológico da religião:

Avec son sens des choses historiques, il [Saint-Simon] avait très clairement aperçu cette loi qui est maintenant passée en axiome : c'est que plus on se rapproche des origines du développement religieux, plus les pratiques rituelles et matérielles priment en importance les croyances et les préceptes purement moraux, tandis que ce sont ces derniers qui deviennent de plus en plus prédominants dans la religion des peuples civilisés (DURKHEIM, 1928, p. 272-273). 
Assim, o que Saint-Simon havia estabelecido como lei, Durkheim diz se tratar de um axioma da evolução religiosa, pois coincide com os resultados de suas próprias pesquisas. O novo cristianismo de Saint-Simon consiste, pois, em “dégager l'idée chrétienne, c'est-à-dire l'idée morale, de tous ces alliages qui la dénaturent, de la rétablir dans sa pureté originelle et d'en faire la base unique du système religieux" (DURKHEIM, 1928, p. 273). Durkheim avalia a nova religião de Saint-Simon como "un panthéisme, affirmant l'identité fondamentale de tous les êtres", concebendo deus como uma força imanente ao mundo que funda o princípio de fraternidade na realidade mesma das coisas e, assim, "peut servir à justifier rationnellement une morale de la solidarité" (DURKHEIM, 1928, p. 279). Nesses termos, Durkheim é simpático à ideia de Saint-Simon, qual seja, aquela que define a nova religião como uma purificação da moral que mantém seu caráter religioso de autoridade, na medida em que ela é convergente com a sua interpretação do declínio das crenças e práticas tradicionais como forças regulatórias na sociedade moderna.

Concomitantemente à análise do processo de progressiva autonomia da personalidade individual, Durkheim estuda o desenvolvimento histórico da legislação sobre o suicídio e atesta que a proibição deste último se tornou, paulatinamente, cada vez mais radical. Tal reprovação diz respeito à emergência dessa nova concepção de pessoa humana que passou a ser, para as sociedades cristãs, a coisa sagrada por excelência. A alma é considerada uma parte divina e imortal da pessoa, que a torna sagrada para si mesma. Com efeito, o suicídio "est donc réprouvé parce qu'il déroge à ce culte pour la personne humaine sur lequel repose toute notre morale" (DURKHEIM, 1897a, p. 379). Como único objetivo coletivo da sociedade moderna, a pessoa humana assume um caráter religioso, o princípio essencial da nova religião da humanidade. Por essa razão, o suicídio lesa não apenas o indivíduo, mas fundamentalmente, a sociedade, pois "le sentiment sur lequel reposent aujourd'hui ses maximes morales les plus respectées, et qui sert presque d'unique lien entre ses membres, est offensé, et qu'il s'énerverait si cette offense pouvait se produire en toute liberté" (DURKHEIM, 1897a, p. 383). Em 1898, em seu primeiro artigo de intervenção no debate público em defesa do individualismo, Durkheim (1898a, p. 8) afirma que a pessoa humana "est considérée comme sacrée", na medida em que se tornou transcendente e subtraída da circulação comum, a ponto de qualquer atentado à vida, à liberdade ou à honra de uma pessoa 
provocar-nos o mesmo sentimento de horror que sente o fiel diante da profanação de seu ídolo. Esse ideal de pessoa constituiria uma religião, isto é, um sistema de crenças que fixa todos a uma fé comum de exaltação do indivíduo em geral e que garantiria, assim, a unidade moral da sociedade. Nesse sentido, Durkheim concebe então a religião como "un ensemble de croyances et de pratiques collectives d'une particulière autorité" e, consequentemente, afirma que "une religion n'implique pas nécessairement des symboles et des rites proprement dits, des temples et des prêtres ; tout cet appareil extérieur n'en est que la partie superficielle" (DURKHEIM, 1898a, p. 10; grifo nosso). Contra os que reclamam o retorno das religiões tradicionais como a única solução capaz de reestabelecer a unidade moral, Durkheim aponta que com o aumento da densidade e volume das sociedades, a comunhão espiritual "ne peut plus se faire sur des rites et des préjugés définis" (DURKHEIM, 1898a, p. 11), que não são plásticos nem maleáveis o suficiente e, assim sendo, oferecem muita resistência às variações individuais que também são cada vez mais acentuadas. Desse modo, nada mais sobra de comum para adorar a não ser o próprio homem, naquilo que cada um encarna do ideal de humanidade e que torna a personalidade individual sagrada e inviolável. Mais do que desejável, a religião da humanidade seria, portanto, a única religião possível à qual a sociedade moderna poderia aderir, formando assim, entre seus membros, uma comunidade moral.

\subsection{O Année sociologique e a origem religiosa das interdições matrimoniais}

No prefácio do segundo volume do Année, Durkheim (1899a) sublinha a primazia da religião desde o primeiro volume da revista, considerado o germe do qual derivam boa parte dos fenômenos sociais. Em carta a Marcel Mauss de dezembro de 1897, Durkheim já havia afirmado que "cette importance sociologique du phénomène religieux est l'aboutissement de tout ce que j'ai fait" (DURKHEIM, 1998, p. 91). Em resenha publicada na Revue philosophique, Durkheim havia criticado determinada concepção historiográfica materialista por estabelecer organização econômica como fenômeno social elementar e motor do progresso histórico. Essa hipótese marxista seria contrária aos fatos estabelecidos pois, no princípio, "le facteur économique est rudimentaire, alors que la vie religieuse est, au contraire, luxuriante et envahissante" (DURKHEIM, 1897b, p. 650). Comentando em outro artigo sobre a independência 
relativa das representações coletivas em relação à morfologia social, Durkheim atesta o frequente equívoco em desconhecer o caráter social da religião simplesmente "parce qu'on ne voyait pas de lien immédiat entre la plupart des croyances religieuses et l'organisation des sociétés" (DURKHEIM, 1898b, p. 300). Muito embora sublinhe que há, sempre, alguma relação entre a estrutura social e as representações religiosas, essa "végétation luxuriante de mythes et de légendes, tous ces systèmes théogoniques, cosmologiques, etc., que construit la pensée religieuse ne se rattachent pas directement à des particularités déterminées de morphologie sociale", tendo em vista que essas representações, uma vez constituídas, possuem autonomia e "ont pour causes prochaines d'autres représentations collectives, non tel ou tel caractère de la structure sociale" (DURKHEIM, 1898b, p. 299). Na origem tudo é religioso, e é das transformações da religião que derivam diversas ações coletivas, tais como arte, ciência, direito, moral, política etc. Portanto, conforme seu parecer: "Sociologues et historiens tendent de plus en plus à se rencontrer dans cette affirmation commune que la religion est le plus primitif de tous les phénomènes sociaux" (DURKHEIM, 1897b, p. 650).

No artigo que inaugura o Année, "La prohibition de l'inceste et ses origines", Durkheim investiga a proibição do incesto a partir do estudo de sua instituição originária, qual seja, a exogamia. Tal estudo faz parte de seu projeto de sociologie morale et juridique e, mais especificamente, de estudo das questões relativas à sociologia jurídica e moral da família, isto é, o estudo das regras de parentesco. Em uma das resenhas do Année, Durkheim afirma que "toute parente est sociale ; car elle consiste essentiellement en relations juridiques et morales, sanctionnées par la société" (DURKHEIM, 1898e, p. 318; grifo nosso). Tal proposta compreende remontar a origem primeira de instituições e regras morais e, assim, estabelecer a influência que a instituição de origem exerce no desenvolvimento e na conformação atual da regra moral de proibição do incesto. Segundo Durkheim (1898c, p. 2), designa-se por exogamia "la règle en vertu de laquelle il est interdit aux membres d'un même clan de s'unir sexuellement entre eux", compreendendo o clã como um grupo de indivíduos que se consideram parentes exclusivamente por serem portadores de um mesmo totem. Dessa perspectiva, se o incesto consiste na união sexual entre indivíduos com grau de parentesco proibitivo no que diz respeito ao exercício dessa união - isto é, indivíduos do mesmo clã -, está fundada a relação entre a exogamia e a proibição do incesto que 
permite a Durkheim investigar a primeira para estabelecer conclusões sobre a segunda. A exogamia é, portanto, a forma mais primitiva de proibição do sistema matrimonial, de tal modo que “[t]outes les interdictions qu'on observe dans les sociétés inférieures en sont dérivées" (DURKHEIM, 1898c, p. 28).

No entanto o parentesco do clã não pode ser determinado por qualquer relação de consanguinidade e deve-se, antes, ao culto do totem. Conforme afirma em outra resenha do Année, o totem constitui "le signe auquel ils reconnaissent leur parente" (DURKHEIM, 1898f, p. 328). Durkheim propõe investigar a causa da exogamia nas crenças religiosas das sociedades primitivas. Conforme observa, a exogamia " $n$ 'est qu'un cas particulier d'une institution religieuse, beaucoup plus générale, qu'on retrouve à la base de toutes les religions primitives, et même, en un sens, de toutes les religions. C'est le tabou" (DURKHEIM, 1898c, p. 39). Termo tomado por empréstimo da língua polinésia, Durkheim define os tabus como

un ensemble d'interdictions rituelles qui ont pour objet de prévenir les dangereux effets d'une contagion magique en empêchant tout contact entre une chose ou une catégorie de choses, où est censé résider un principe surnaturel, et d'autres qui n'ont pas ce même caractère ou qui ne l'ont pas au même degré. Les premières sont dites tabouées par rapport aux secondes (DURKHEIM, 1898c, p. 39).

Em consonância com sua análise dos fenômenos religiosos centrada na relação entre regra e sanção, Durkheim encontra na noção de tabu uma espécie de aprimoramento de sua própria abordagem, estabelecendo-o no artigo em questão como a instituição religiosa elementar. Como interdição ritual, o tabu diz respeito a uma proibição de contato entre a substância sobrenatural e as demais coisas naturais e ordinárias, cuja proteção contra possíveis violações é garantida por uma sanção divina levada a cabo pela sociedade contra o transgressor. Com efeito, a exogamia mantém relação íntima com o tabu se considerarmos que ela consiste, igualmente, na proibição do contato sexual entre homens e mulheres de um mesmo clã: "Les deux sexes doivent mettre à s'éviter le même soin que le profane à fuir le sacré, et le sacré le profane ; et toute infraction à la règle soulève un sentiment d'horreur qui ne diffère pas en nature de celui qui s'attache à toute violation d'un tabou" (DURKHEIM, 1898c, p. 40). Nesse sentido, as interdições sexuais da exogamia não diferem em natureza das interdições rituais dos seres e objetos tabu; as primeiras são apenas uma variedade das segundas e, portanto, devem poder ser explicadas da mesma maneira. 
De acordo com Durkheim, a causa comum que explica ambas as interdições pode ser buscada no totemismo. Ao mesmo tempo ancestral divino e objeto de culto do grupo, o ser totêmico constitui o centro da religião clânica; e, mais do que isso, está encarnado no sangue e nos indivíduos: é, portanto, imanente ao clã. Com efeito, se o divino reside no próprio sangue e, principalmente, se tudo que é divino é marcado como tabu, "il est donc naturel que le sang et ce qui le concerne soient également tabous, c'est-à-dire retirés du commerce vulgaire et de la circulation" (DURKHEIM, 1898c, p. 53). Temos, por um lado, o totem como símbolo desse sistema de abstenções organizadas ou tabus, considerados causa comum da religião e da exogamia e, por outro, o clã, considerado o centro da vida religiosa e da moralidade do grupo. Não obstante, Durkheim reconhece que há uma outra dimensão da sexualidade que extrapola a regulação da conduta sexual exercida pela exogamia e se opõe à moralidade familiar, a saber: a dos instintos e do erotismo, que está ligada, antes, às dimensões intelectual e emocional da vida sexual. Segundo o autor:

c'est ainsi que les idées relatives à la vie sexuelle se sont étroitement liées au développement de l'art, de la poésie, à tout ce qui est rêves et aspirations vagues de l'esprit et du cour, à toutes les manifestations individuelles ou collectives où l'imagination entre pour la plus large part. [...] Mais ces additions et ces transformations sont des phénomènes secondaires (DURKHEIM, 1898c, p. 66; grifo nosso).

Durkheim considera a vida sexual que existe fora da regulação familiar como fonte da atividade estética em geral, em que a imaginação, a fantasia e as emoções têm um papel preponderante. Ainda assim, tal atividade é considerada apenas um fenômeno secundário e mesmo marginal da sexualidade nas sociedades primitivas, tendo em vista que o sistema de interdições matrimoniais constitui o núcleo da vida moral e religiosa do clã. Recapitulando a explicação, é da combinação da noção vulgar de sangue com as crenças totêmicas que se originam os ritos de interdição e estes, em contato com o comércio sexual, engendram as ideias relativas à exogamia. Na conclusão do trabalho, Durkheim afirma que as representações coletivas que estão na base de nosso temperamento moral sobre o incesto, apesar de muito rudimentares na origem, podem iluminar a vontade social no curso de seu desenvolvimento, tornando-a "plus apte à diriger le cours des événements et à leur imprimer une marche rationnelle" (DURKHEIM, 1898 c, p. 70). Note-se, por fim, a menção à dualidade da vida religiosa, especialmente 
aquela ligada à dualidade entre divino e mundano. Durkheim passou a identificar o termo sagrado como um sentido correlato da noção de tabu. Ao comentar sobre o horror que temos do incesto, afirma: “L'horreur qu'elles nous inspirent est identique à celle qu'éprouve le sauvage à l'idée d'un mélange possible entre ce qui est tabou et ce qui est profane" (DURKHEIM, 1898c, p. 59). Como é possível notar, Durkheim introduz o termo sagrado entre 1897 e 1898, ainda sem qualquer elaboração conceitual, apenas como sinonímia de tabu. É preciso questionar, então, de onde pode ter vindo essa identidade entre as noções de tabu e de sagrado.

Ainda no primeiro número do Année, Durkheim resenha dois artigos de Mauss publicados em 1896 e 1897 na Revue de l'histoire des religions sobre a origem religiosa do direito penal a partir da obra de Steinmetz ${ }^{3}$. A resenha atesta o início do emprego da noção de sagrado por Durkheim, ainda subordinada à instituição religiosa dominante de sua análise, o tabu. Segundo Durkheim, Mauss teve o mérito tanto de apresentar o que a Sociologia pode aproveitar do trabalho de Steinmetz quanto de avaliar e corrigir suas teorias e apresentar uma discussão bem documentada e propriamente sociológica das origens da pena primitiva. Em concordância com Mauss, Durkheim salienta positivamente o caráter não finalista e religioso da pena primitiva, e endossa as conclusões de Mauss sobre a origem religiosa da vingança privada e da pena pública: a primeira por causa da solidariedade religiosa de sangue do clã; a segunda por causa das sanções relativas às interdições rituais, os tabus. Conforme a conclusão de Durkheim:

L'auteur [Mauss] a bien voulu la présenter comme inspirée par nos théories sur la peine et la religion; elles viennent en effet confirmer ce que nous avons dit ailleurs sur les origines religieuses de la peine. Mais l'originalité de cette étude ne reste pas moins considérable. Nous avions bien pu établir le caractère religieux des peines primitives d'une manière générale ; mais nous nous en étions tenu là. M. Mauss a su démêler dans le tabou l'institution religieuse d'où dérive cette religiosité $d u$ droit pénal et nous croyons l'idée féconde (DURKHEIM, 1898d, p. 357; grifo nosso).

De acordo com a conclusão, Mauss parte da teoria de Durkheim sobre a origem religiosa da pena, expressa em De la division du travail social. Contudo, a filiação de Mauss à Durkheim não o limita a reproduzir as conclusões gerais que o último havia apresentado anos antes. Partindo do esquema geral de Durkheim, Mauss apresenta uma conclusão mais precisa sobre a origem religiosa da pena, isto é, da sanção oriunda do

3 Esses artigos iniciais de Mauss serão analisados no capítulo seguinte. 
tabu, considerada como um rito religioso. Comentando a impossibilidade de a vingança ser a base do sistema penal ante a infinidade de interdições religiosas que sancionam a pena de morte, Durkheim remonta a inovação da contribuição de Mauss e afirma: "Tout ce qui soutient un rapport un peu intime avec le culte, homme, animal ou chose, est sacré, ou, pour employer l'expression usitée, taboué" (DURKHEIM, 1898d, p. 356). Por um lado, a noção religiosa de tabu diz respeito à inviolabilidade de qualquer objeto considerado tabu, na medida em que o desrespeito ao interdito é severamente punido. Durkheim reafirma que, em se tratando do sistema penal, "la cause em doit être recherchée dans l'institution religieuse du tabou", coincidindo com a tese de Mauss, que aponta que uma das fontes do sistema penal são "les interdictions rituelles qui résultent des pratiques et des croyances relatives au tabou" (DURKHEIM, 1898d, p. 357). Mas, para além disso, temos a introdução do sagrado como correspondente em algum sentido ao tabu. Portanto, Durkheim introduz o sagrado ainda como um termo ordinário, não para contradizer a abordagem sociológica desenvolvida até então, mas, pelo contrário, para reforçar a análise que culmina na instituição religiosa do tabu.

No segundo artigo publicado no Année, "De la définition des phénomènes religieux", sua proposta consiste em elaborar uma definição de fenômeno religioso e, a partir deste, mostrar os nexos que ele mantém com a religião. Há uma multiplicidade difusa de fenômenos religiosos que não estão necessariamente integrados em algum sistema definido de crenças e práticas à qual damos o nome de religião e, por isso, o nexo entre os fenômenos religiosos e a religião deve também ser construído pela pesquisa. Durkheim critica as tentativas de definir o fenômeno religioso pelo seu conteúdo, isto é, aquelas que tentam decifrar o que inspira o sentimento de respeito religioso. Duas tendências são apresentadas: a dos que definem o fenômeno religioso pela ideia de mistério e aquela dos que o definem pela ideia de deus. Quanto à primeira, Durkheim afirma que a ideia de mistério não é doada ao homem pela religião e, ao contrário, é o homem que forja tanto as ideias de clareza quanto de mistério e as atribui a determinados eventos religiosos no decurso do desenvolvimento das religiões. $\mathrm{O}$ mesmo se aplica ao desenvolvimento da ideia de deus, de uma ordem superior e separada que constitui divindade: existem religiões em que os deuses são parecidos com os homens, sem possuírem qualidades morais superiores, assim como também existem religiões em que a ideia de deus está ausente ou é simplesmente indiferente para os fiéis. 
Durkheim cita o exemplo dos cultos agrários como predecessores da ideia de divindade. $\mathrm{Na}$ origem dos cultos agrários, a própria vegetação é responsável pela ação religiosa, sem qualquer intermediário divino invocado pelos fiéis. O princípio responsável pela renovação da vida do campo está difuso e é um atributo comum a todos os elementos vegetais. Da mesma maneira, o totem não é um ser específico da espécie animal ou vegetal e, por essa razão, não constitui um ser divinizado. Conforme comenta Durkheim:

Le totem, en effet, ce n'est pas tel ou tel membre de l'espèce animale ou végétale qui sert d'emblème au groupe ; c'est toute l'espèce indistinctement. [...] Pour qu'on pût prononcer le mot de dieu, il faudrait que le principe commun à tous ces êtres particuliers s'en fût séparé, et que, hypostasié sous une forme quelconque, il fût devenu lui-même le centre du culte. Il est vrai que certaines peuplades se sont élevées à l'idée d'un être fabuleux d'où seraient descendus, à la fois, et le clan et l'espèce adoptée comme totem. [...] C'est simplement une manière pour les esprits de se figurer l'unité de l'espèce totémisée et les rapports de parenté que le clan est censé soutenir avec elle. Bien loin qu'une telle représentation soit à la base même du totémisme, elle n'a été évidemment forgée qu'après coup pour permettre aux hommes de s'expliquer un système de pratiques préexistantes (DURKHEIM, 1899b, p. 13-14; grifo nosso).

De acordo com o autor, o totem não é animal que serve de emblema ao grupo, mas, antes, toda a espécie animal ou vegetal, que constitui uma vasta categoria de coisas sagradas. Por essa razão, o totem ainda não havia sido separado de todas essas manifestações particulares e tampouco hipostasiado para se tornar o centro de um culto definido e poder ser considerado um ser divino. Quanto a essa potência divina, ela "reste diffuse dans une classe indéterminée de choses", pois "il y a simplement des objets sacrés, par opposition aux objets profanes, mais pas de dieu" (DURKHEIM, 1899b, p. 13). Nesse sentido, os totens que foram alçados à condição de seres fabulosos em alguns grupos são considerados como desenvolvimentos secundários e marginais do totemismo, os quais Durkheim crê se tratarem de representações ideológicas forjadas pelos nativos para explicar o sistema de práticas que regula o parentesco do clã com a espécie totêmica. Isso o leva a concluir que a ideia de divindade é secundária e, principalmente, que a distinção das coisas entre sagradas e profanas é anterior e independente da ideia de deus.

Para Durkheim, todas as definições anteriores se equivocaram ao querer exprimir de imediato o conteúdo da vida religiosa. O conteúdo dos fenômenos é algo que só pode 
ser determinado à medida que a ciência avança, não de antemão. Somente a forma exterior e aparente dos fenômenos é imediatamente acessível à observação e, portanto, é a ela que temos de recorrer para definir os fatos da vida religiosa. Dada a reflexão sobre a anterioridade do sagrado em relação à ideia de divindade, uma primeira e mais imediata tentativa consistiria em definir o culto religioso em termos de "l'ensemble des pratiques qui concernent les choses sacrées"; mas, pondera Durkheim, essa estratégia apenas substitui uma ideia por outra igualmente obscura que, em si mesma, não traz nenhuma clareza, tampouco resolve o problema, pois "encore faudrait-il savoir em quoi consistent ces choses sacrées et comment on les reconnaît” (DURKHEIM, 1899b, p. 17). Dada a impossibilidade de definir precisamente os fenômenos religiosos pelo sagrado, Durkheim apresenta um grupo de fenômenos que teriam uma característica comum e irredutível, a saber: a existência de comunidades nas quais os membros são formados para aderir a uma fé comum em mitos ou dogmas e que não permitem que seus membros possam negá-la. A obrigação, assim, é o primeiro elemento distintivo do conjunto de fenômenos que se pretende definir, mas com o inconveniente de manter um parentesco direto dos fenômenos religiosos com o direito e a moral. Nesses termos, como distinguir a obrigação dos fenômenos religiosos daquela dos fenômenos jurídicos e morais? Durkheim responde que, a princípio, os fatos religiosos são obrigatórios sem necessariamente possuírem algum tipo de sanção determinada:

Cette interdiction n'est pas toujours sanctionnée par des peines proprement dites. Dans toute religion commune à une société déterminée, il y a des croyances dont la négation ne constitue pas des crimes expressément punis. Mais, même dans ce cas, il y a toujours une pression exercée par la société sur ses membres pour empêcher qu'ils ne devient de la foi commune. [...] Mais il y a toujours un parallélisme exact entre le caractère religieux des croyances et l'intensité do la répression qui en impose le respect : c'est-à-dire que plus elles sont religieuses, plus elles sont obligatoires. Cette obligation tient donc bien à leur nature et peut, par suite, servir à les définir (DURKHEIM, 1899b, p. 18; grifo nosso).

Em outras palavras, mesmo onde não há sanção previamente estabelecida, a sociedade exerce uma certa pressão nos indivíduos, a qual garante a obrigatoriedade da fé e protege as crenças religiosas. Essas interdições dizem respeito à instituição religiosa originária do tabu, utilizada no artigo sobre a origem da proibição do incesto. A forma que aprendemos as tradições nos inspira um respeito especial, diferente de quando aprendemos os processos ordinários, e é essa diferença específica que protege as 
crenças religiosas e faz da transgressão dessas crenças um caso limite. No entanto, no momento seguinte, Durkheim repõe uma indistinção ao admitir que existem crenças comuns relativas a objetos laicos, que são indiscerníveis das crenças religiosas e provocam a mesma reação: "La patrie, la Révolution française, Jeanne d'Arc, etc. Sont pour nous des choses sacrées auxquelles nous ne permettons pas qu'on touche" (DURKHEIM, 1899b, p. 20). Nesses termos, tomando essas crenças por si mesmas, não podemos distinguir com clareza a obrigatoriedade das crenças religiosas daquela das crenças da moralidade laica.

A solução de Durkheim para essa indeterminação reside na volta à análise do conjunto de práticas religiosas, isto é, o culto, tão essencial quanto a fé, mas que não pôde ser anteriormente distinguido das práticas da moral e do direito porque não sabíamos ainda em que consistia a especificidade das coisas religiosas. Com efeito, o que distingue as práticas obrigatórias religiosas das demais é que "les êtres, sur lesquels elles agissent ou sont censées agir, ne sont connus de nous qu'à travers ces représentations collectives très particulières qu'on appelle des mythes et des dogmes" (DURKHEIM, 1899b, p. 21), ou seja, o sistema de práticas é ligado a um sistema de regras que predeterminam o pensamento. Para Durkheim, essa seria a diferença fundamental que permite discernir a religião da ética: por não possuir um caráter religioso, a ética não tem uma base mitológica ou cosmogônica e, sendo assim, suas práticas não estão ligadas a crenças que predeterminam o pensamento. Chegamos, então, à seguinte definição: "Les phénomènes dits religieux consistent em croyances obligatoires, connexes des pratiques définies qui se rapportent à des objets donnés dans ces croyances", enquanto a religião consistiria em "un ensemble, plus ou moins organisé et systematisé, de phénomènes de ce genre" (DurKHEIM, 1899b, p. 22-23). Se o que caracteriza as crenças e práticas religiosas é que elas são obrigatórias, Durkheim reforça que tudo que é obrigatório é de origem social. Toda obrigação implica uma ordem, uma autoridade que a comanda. Dessa forma, para que o indivíduo conforme sua conduta a determinadas regras, essas regras devem provir de uma autoridade moral que se impõe e domina, ou seja, do aspecto coercitivo dos sentimentos coletivos em oposição à relativa liberdade dos sentimentos individuais.

Nesse sentido, em seu curso ministrado em Bordeaux no mesmo ano, 1899, intitulado Physique générale du droit et des mours, Durkheim retoma o problema da 
origem religiosa das sanções repressivas. No único manuscrito datado desse curso, de 2 de dezembro de 1899, o autor afirma que as sanções "avaient toutes pour racine historique certaines pratiques religieuses, qu'elles étaient dérivées de certaines opérations rituelles", o que envidenciaria "l'étroite parenté du religieux et du moral" (DURKHEIM, 2020, p. 35). Concentrando-se nas sanções repressivas organizadas, ou seja, as sanções penais, ele as define como "toute sanction privative ou destructive dont la nature et la grandeur, variable proportionnellement à l'infraction est fixée par un corps social chargé de cette fonction" (DURKHEIM, 2020, p. 37); ou ainda, dito de outra maneira, "la peine est une sanction privative ou destructive" (DURKHEIM, 2020, p. 41). Nesse sentido, a definição de Durkheim enfatiza a destruição como um efeito mecânico da reação passional à violação de uma regra de conduta obrigatória, e exclui, por exemplo, o sofrimento, considerado um elemento ideológico e de senso comum sobre a penalidade. Ao remontar as práticas rituais que fundamentam essa noção de pena, Durkheim retoma sua análise do judaísmo antigo e, mais especificamente, da Torá, considerada o caso paradigmático da unidade entre religião, direito e moral primitiva. Ele comenta, então, duas passagens que ilustram seu raciocínio sobre a ausência de sofrimento da expiação primitiva:

En premier lieu, il y a les peines ou le patient est un objet inanimé, par conséquent insensible. Ainsi, l'instrument du crime est très souvent détruit. Quand dans une ville avait eu lieu cette propagande en faveur de l'idolâtrie la Bible prescrivait de détruire tout ce qui s'y trouvait, non seulement les gens mais aussi les choses (Deut[éronome], XIII, 16). L'habitude de raser la maison du supplicié est de même nature : une telle destruction n'est douloureuse ni pour le condamné qui n'est plus, ni pour la maison elle-même. Ont le même caractère tous ces compléments de peine qui n'ont pour matière qu'un cadavre. Très souvent la loi ordonne non seulement de mettre à mort le coupable, mais encore de laisser son corps pourrir au gibet, ou s'il est brûlé de jeter ses cendres au vent ou de traîner son cadavre sous le char, etc. [...] Dans d'autres cas, quand c'est un animal qui a commis le crime, c'est lui qui est frappé. "Si un bœuf heurte de sa corne un homme ou une femme, et que la personne en meure [...] le bœuf sera lapidé et on ne mangera point de sa chair" (Exode, XXI, 28). Il est vrai que l'animal est accessible à la douleur, mais ce qui montre bien que la destruction n'a pas simplement pour objet de le faire souffrir, c'est cette prescription : on ne mangera pas de sa chaire. Il s'agit non de torturer un être vivant, mais de retirer du commerce un être impur (DURKHEIM, 2020, p. 40).

Nos dois casos citados, Durkheim chama a atenção para o elemento comum da pena primitiva, qual seja, a expiação do crime por meio de uma prática ritual que visa a aniquilação completa dos seres e coisas relacionados à violação da regra de conduta 
obrigatória. Ora, que rito é esse que Durkheim crê estar na origem da sanção penal? Precisamente aquele que o fez encomendar um artigo original a Hubert e Mauss para figurar ao lado do seu no segundo volume do Année: o sacrifício. Durante a troca de cartas com seu sobrinho nos meses de junho e julho de 1898, Durkheim identifica que as teorias do sacrifício de Smith e Frazer haviam negligenciado "un élément essentiel du sacrifice, qui est la destruction" (DURKHEIM, 1998, p. 154; grifo nosso). Em outra carta do mesmo período, ele conclui: "Mais ce qui me paraît certain, c'est que l'idée pénale est l'âme de toute une série de sacrifices" (DURKHEIM, 1998, 162; grifo noosso). Dessa maneira, Durkheim acreditava que o sacrifício penal seria tanto o coroamento de sua produção anterior quanto ponto de partida de sua contribuição substantiva à sociologie religieuse, confiando a Hubert e Mauss a realização dessa tarefa.

\subsection{Conclusão}

Ao analisarmos os textos de Durkheim que tratam da religião e dos fenômenos religiosos entre 1886 e 1899, pudemos constatar que a investigação dos fenômenos religiosos se manifesta de maneira subordinada à análise dos fenômenos morais ao longo de todo o período. Desde a elaboração de sua tese de doutorado, Durkheim estabelece que os fenômenos religiosos, morais e jurídicos constituem uma síntese primitiva, e desenvolve uma abordagem para estudar o conjunto de forças reguladoras da sociedade. Nesse momento, a religião aparece como a manifestação primitiva dos estados fortes da consciência coletiva, cuja fé comum em torno de um conjunto de regras de conduta obrigatórias produz uma comunidade moral. Com efeito, a violação dessas regras obrigatórias é caracterizada como crime e tem por consequência a reação passional da coletividade na forma de sanções penais. No momento de criação do Année, Durkheim desdobra outra frente de estudo que toma a religião como fato primitivo, investigando as regras de exogamia do clã a partir das interdições matrimoniais que conformam tanto a organização social quanto a religião dos grupos totêmicos. Todos esses casos apontam, portanto, para a continuidade da mesma e única abordagem desenvolvida por Durkheim até então, qual seja: aquela da sociologie morale et juridique, centrada no estudo do funcionamento das regras de conduta obrigatórias por meio da manifestação de seus símbolos exteriores, sejam estes sanções repressivas ou interdições rituais. Tal abordagem sustenta que a regras de conduta 
obrigatórias constituem o núcleo da vida coletiva, e que sanções e interdições simbolizam objetivamente esse conjunto de forças coletivas fundamentais. De fato, Durkheim estabelece que as regras de conduta e suas respectivas formas de expressão simbólicas variam de acordo com a morfologia de cada tipo social em questão. Centrada nas questões relativas ao dever moral, a abordagem de Durkheim toma a religião, a moral e o direito como formas de disciplina social que objetivam tanto integração social quanto a regulação da conduta e do pensamento individuais. Assim, além de considerar, desde o princípio, a religião como germe de todos os fenômenos sociais, Durkheim sustentou que a abordagem desenvolvida no âmbito da sociologie morale e juridique permitiria estudar objetivamente qualquer fenômeno social - inclusive os religiosos. Portanto, de acordo com a expectativa de Durkheim, a sociologie morale e juridique desembocaria, naturalmente, na sociologie religieuse nascente.

Não obstante, o desenvolvimento da reflexão de Durkheim sobre a religião ao longo desse período foi acompanhando por outros desenvolvimentos necessários para a o estabelecimento de uma abordagem sociológica para os fenômenos religiosos, morais e jurídicos. Do ponto de vista metodológico, além de tratar os fenômenos como coisas, proceder à definição e à identificação dos signos exteriores imediatamente acessíveis à observação e explicá-los causalmente, a relação entre regra interna e sanção externa, entre obrigação e constrangimento ou proibição, desenvolvida inicialmente para análise do funcionamento das regras de conduta obrigatórias, é desdobrada para analisar os fenômenos religiosos. Em seu artigo sobre a definição dos fenômenos religiosos (1899), percebemos como a noção de obrigação permanece central e é sustentada como aquela que melhor exprime a natureza da coisa religiosa, até mesmo contra a pertinente, mas ainda considerada obscura, noção de sagrado. Do ponto de vista do objeto de análise, o judaísmo antigo é considerado caso paradigmático de religião primitiva, figurando desde sua tese de doutorado até o último curso ministrado por Durkheim no período. Dessa maneira, Durkheim dá preferência ao estudo de sociedades com escrita e seus respectivos códigos, como a torá, mantendo distância da análise de documentos etnográficos de sociedades sem escrita.

Já do ponto de vista teórico, temos, por um lado, a identificação dos fenômenos jurídicos, morais e religiosos como o conjunto de forças reguladoras, capazes de formar sociedade e garantir a coesão social. Com efeito, é uma característica tanto da moral 
quanto da religião a chamada fé comum e a consequente disciplina social, elementos fundamentais para a formação de uma comunidade moral. Tanto a moral quanto a religião correspondem aos estados fortes da consciência coletiva e consistem em regras de conduta obrigatórias. Essa correspondência mesma é percebida nos artigos para o Année, seja na relação entre regra moral as interdições matrimoniais - que conformam a religião do clã -, seja no caráter religioso que possuem as crenças comuns da moralidade laica. Tal ênfase de Durkheim na obrigação como noção central de sua concepção tanto de religião quanto de moral revela um traço importante de sua inspiração na filosofia prática kantiana, pois, conforme esclarece Watts Miller (1996, p. 11): "Like Kant, Durkheim talks of 'obligation' to refer not to the content of duty but to the imperativeness moving and constraining us to act on it". Portanto, a ideia de obrigação para Durkheim diz respeito muito mais à dimensão do dever moral do que ao conteúdo que os fenômenos sociais encerram. Com efeito, Durkheim sustenta que é preciso identificar na realidade o signum certum que simboliza objetivamente os sentimentos sociais fundamentais, como quando as sanções ou as interdições simbolizam as regras de conduta obrigatórias. Em uma palavra, os símbolos são relevantes apenas quando revelam o fundamento do dever ou o caráter obrigatório de determinadas regras, sejam essas regras orientadoras da prática ou do pensamento. Por outro lado, Durkheim designa os símbolos religiosos como formas superficiais e mesmo dispensáveis da consciência coletiva e, da mesma maneira, atribui um caráter marginal às manifestações estéticas e emocionais da religião e da moral. Em ambos os casos, Durkheim os considera produtos da imaginação potencialmente subjetivos, que são, por essa razão, tidos como marginais em relação ao conjunto de regras que constituem o núcleo da vida social.

Por último, do ponto de vista evolucionário, no princípio a religião, a moral e o direito encontravam-se em uma síntese confusa, concepção esta que se mantém desde a investigação sobre origem religiosa da pena primitiva até os estudos acerca das interdições matrimoniais como símbolos da religião do clã. No decurso do desenvolvimento histórico, a falência das crenças e práticas tradicionais e a consequente sagração da personalidade individual mantêm a ligação entre moral e a religião, na medida em que a nova unidade moral da consciência coletiva carrega consigo uma marca de religiosidade. Temos aí uma dupla dinâmica de evolução: 1) da dissociação 
entre representações coletivas e morfologia social; 2) da progressiva expurgação dos elementos superficiais religiosos e morais e a consequente depuração de seus elementos racionais. Na primeira, Durkheim concebe que as crenças religiosas e morais seriam, no princípio, um reflexo de certos traços da estrutura social; com o desenvolvimento histórico, esses elementos tenderiam a se dissociar e as representações coletivas alcançariam uma relativa autonomia em relação à estrutura social correspondente. $\mathrm{Na}$ segunda, Durkheim considera que embora mitos e ritos sejam constituintes do religioso em sua origem, eles teriam nessa origem uma relação de particularismo local que dificultaria o processo de generalização dos elementos racionais dessas crenças e práticas. Por essa razão, entende que mitos e ritos não seriam mais que invólucros superficiais a serem progressivamente abandonados durante o processo de depuração das crenças e práticas religiosas. Esse longo processo de autocompreensão esclarecida da sociedade guiada pela ciência culminaria, por conseguinte, no ideal de transparência dos elementos morais e racionais que caractetiza a nova religião da humanidade. Como observa Watts Miller, para entender o projeto de ciência social concebido por Durkheim, é preciso compreender "the theme and metaphor of transparence. It is in his very emphasis on obscure forces that his aim is to bring the hidden to light, which at the same time helps to free us from blind mechanisms and bring these under control" (WATts Miller, 2012, p. 17). Assim, o ideal de transparência de Durkheim significa "his hope not only in social science but in movement towards a society with transparent self-understanding” (WATTS MiLlER, 2012, p. xi)

Desse modo, a análise que realizamos permite dissipar certos mal-entendidos a respeito da mudança e da continuidade na reflexão de Durkheim sobre a religião nesse período. Em primeiro lugar, não é possível constatar nenhuma mudança de Durkheim a respeito dos fenômenos religiosos nos anos próximos de 1895, data da suposta "revelação" ocorrida a partir da leitura de Roberston Smith. Como vimos, a grande revolução do curso ministrado por Durkheim naquele ano foi, simplesmente, em estender a abordagem da sociologie morale et juridique à análise aos fenômenos religiosos e tratá-los como coisas. Mesmo as modificações introduzidas, a exemplo da descoberta do tabu como fenômeno religioso primitivo e o consequente estudo das interdições como símbolos da religião do clã, foram interpretados por Durkheim na época não na forma de uma ruptura, mas como um desdobramento da abordagem 
centrada no estudo das regras de conduta obrigatórias. Na famosa carta de Paul Lapie a Celestin Bouglé, de maio de 1897, apesar de reclamar que Durkheim "explique tout, en ce moment, par la religion" e que "tout est religieux", o próprio Lapie complementa que esse tudo significa, especificamente, que "l'interdiction des mariages entre parents est affaire religieuse; la peine est un phénomène d'origine religieuse" (LAPIE, 1979, p. 39; grifo nosso). Ademais, Durkheim sublinha a impossibilidade de definir os fenômenos religiosos pela noção de sagrado, justamente criticada por se tratar ainda de um termo ordinário e impreciso, carente de elaboração conceitual, que não faz a definição avançar no conhecimento da coisa definida. Temos, portanto, a despeito das nuances, a manutenção de sua mesma abordagem de análise entre 1886 e 1899. 


\section{Capítulo 2. \\ Mauss e a emergência da sociologie religieuse: o drama sagrado e a gênese das ideias e práticas coletivas}

A proposta deste capítulo é investigar a contribuição de Marcel Mauss para a análise sociológica dos fenômenos religiosos, tomando por referência o período que corresponde à elaboração da sociologie religieuse por Mauss enquanto editor do Année sociologique. Tal período compreende desde a sua primeira publicação acadêmica, "La religion et les origines du droit pénal" (1896), até seu último artigo publicado no Année, "Essai sur les variations saisonnières des sociétés eskimos" (1906). A seleção dos trabalhos analisados correspondeu a todas as publicações de Mauss durante o período citado que tratam dos fenômenos religiosos, incluindo cursos, artigos e resenhas ${ }^{1}$. Nesse sentido, nossa análise enfatiza a criação, por parte de Mauss, de uma nova abordagem sociológica para os fenômenos religiosos baseada na reinterpretação crítica tanto da sociologia durkheimiana quanto da história e antropologia das religiões vigentes à época. Dessa maneira, as inovações introduzidas pelos trabalhos de Mauss vão desde as regras para observação e explicação dos fenômenos religiosos até a elaboração de ferramentas conceituais adequadas para a compreensão da natureza sagrada e da forma dramática dos fenômenos religiosos elementares. Conforme pretendemos demonstrar, Mauss é responsável por elaborar a teoria do drama sagrado, centrada nas capacidades estéticas e afetivas da ação ritual, que marca o advento da sociologie religieuse enquanto uma sociologia comparada das formas religiosas elementares.

$\mathrm{O}$ capítulo está subdividido em seis partes. $\mathrm{Na}$ primeira parte, apresentamos as contribuições de Mauss anteriores ao Année, notadamente sobre a noção de regra sagrada do tabu polinésio e a origem das sanções penais. A segunda parte concentra-se

1 Durante esse período, Mauss escreveu em colaboração: dois artigos com Henri Hubert, "Essai sur la nature et la fonction du sacrifice" (1899) e "Esquisse d'une théorie générale de la magie" (1904); um artigo com Émile Durkheim, "De quelques formes primitives de classification" (1903); um artigo com Paul Fauconnet, "Sociologie" (1901); e um artigo com Henri Beuchat, "Essai sur les variations saisonnières des sociétés eskimos" (1906). Sempre que a informação sobre a divisão do trabalho entre os autores era completa ou parcialmente disponível, enfocamos as partes redigidas por Mauss, 
na explicação sobre o mecanismo de funcionamento do sacrifício, isto é, na sua capacidade de transformar religiosamente os objetos por meio da ação dramática das forças sagradas. A terceira parte é dedicada a evidenciar a avaliação de Mauss acerca do estado da arte na área de ciência comparada das religiões, isto é, como o autor avalia o conhecimento teórico e etnográfico disponível da época para então explicitar a proposta da sociologie religieuse. Na quarta parte, será tratado o problema da magia como fenômeno social, com ênfase na análise de Mauss sobre os rituais mágico-religiosos nas sociedades elementares, evidenciando como estes dramas estão na origem das crenças e práticas sociais destas últimas. A quinta parte diz respeito à análise empreendida por Mauss acerca das relações dinâmicas entre físiologia e morfologia social, visando explicitar a sazonalidade dos fenômenos de efervescência que conformam a lei do ritmo da vida coletiva. Por fim, a última parte é dedicada a realizar uma síntese da análise empreendida e seus resultados, destacando a inovação da abordagem da sociologie religieuse em relação à abordagem da sociologie morale et juridique para os fenômenos religiosos.

\subsection{As origens religiosas do direito penal}

Enquanto ainda era aluno da École Pratique des Hautes Études (EPHE), Mauss debuta no meio acadêmico com a publicação de "La religion et les origines du droit pénal" em 1896, um ensaio crítico sobre um livro do cientista social holandês Sebald Rudolf Steinmetz ${ }^{2}$. Publicado em duas partes na Revue de l'histoire des religions, o ensaio expõe, pela primeira vez, algumas das ideias fundamentais que do que seria, para Mauss, a verdadeira ciência comparada das religiões, isto é, a emergente sociologie religeuse. No que diz respeito ao método empregado, Steinmetz filia-se ao princípio de evolução, qual seja, aquele no qual todas as instituições e pensamentos dos povos são tidos como diferentes estágios e estados do mesmo caráter humano. Segundo Mauss, é fácil reconhecer nesse princípio "celui de toute l'école anthropologique, celui de l'unité de fond de l'esprit humain" (MAUSS, 1896, p. 272). Essa referência à escola antropológica diz respeito, principalmente, aos trabalhos de Robertson Smith e James Frazer, considerados o cânone dos estudos sobre religião primitiva na época; mas se estende também a seus divulgadores na França, como Léon Marillier, professor e

2 Para compreender a importância de Steinmetz para o desenvolvimento das ciências sociais na Holanda, cf. Herman van der Wusten (2005). 
antecessor de Mauss na cadeira de religião primitiva da EPHE. Steinmetz compartilha com todos esses autores da explicação psicológica dos fenômenos sociais, isto é, que "[1]a psychologie de l'individu forme le fondement de la psychologie sociale" (MAUSS, 1896, p. 273). Nesse sentido, Steinmetz pretendia realizar uma etologia do caráter dos povos selvagens e explicar a pena primitiva em razão do que ele designa como caráter vingativo e cruel desses povos. Assim, de acordo com Steinmetz, a pena primitiva tem origem na vingança privada ligada ao culto dos mortos: a vingança do morto forma o princípio de todo o direito penal primitivo e onde há pena, há culto dos mortos. Ao analisar a estatística da chamada vingança de sangue tendo por amostra um número extenso de povos, Steinmetz concluiu que o culto dos mortos seria a razão dessa modalidade de pena primitiva. Para os grupos analisados, a alma dos mortos continuaria viva e reclamaria por vingança, não descansando até que o sangue inimigo seja derramado. Os parentes, por sua vez, temendo a cólera da alma do morto, se incubem da tarefa de aplacá-la por meio da vingança - eis o mecanismo explicativo apresentado por Steinmetz. Dessa forma, esse tipo de vingança consistiria no tipo mais primitivo de pena e também estaria na origem do sacrifício funerário humano. Além da evolução da vingança privada, temos também em Steinmetz o processo de composição dos grupos que dá origem à pena pública. Se a vingança de sangue era apenas uma reação contra a dor, a pena pública diz respeito à indignação da sociedade organizada contra a violação de suas regras morais estritas por atos considerados perigosos para o grupo como um todo. E entre os primeiros crimes que foram punidos pela autoridade pública estão os crimes religiosos, tais como os atos de feitiçaria, sacrilégio e incesto. A respeito do último, este consiste na cólera dos deuses, que é, para Steinmentz, nada mais que o eco da ira do povo contra a violação à regra sexual dentro do clã, isto é, à regra de exogamia. A esse respeito, Mauss comenta:

D'ailleurs, à l'origine, l'inceste est simplement la violation d'une règle d'exogamie. Tout rapport sexuel dans le clan était interdit sous peine de mort. M. Steinmetz constate le fait et ne l'explique pas, avec raison d'ailleurs, la question de l'exogamie étant encore loin d'être tranchée, sauf sur un point : que c'est une règle religieuse (MAUSS, 1896, p. 293).

Dessa maneira, se o incesto é reconhecido no debate especializado como uma violação à regra de exogamia, esta, por sua vez, ainda está longe de ser esclarecida, exceto pelos apontamentos de que se trata de uma regra religiosa. Para Steinmetz, apesar dos crimes 
religiosos serem os primeiros punidos pela autoridade pública, estes não passariam de eventos esporádicos da vida indígena. Steinmetz, portanto, reconhece a religião como fonte das primeiras regras morais, mas observa que seu papel foi secundário na evolução do direito penal.

Em seguida, Mauss dedica a segunda parte de seu ensaio a contrapor as conclusões de Steinmetz ao conhecimento existente sobre religião primitiva e sociologia. Em especial, ele menciona dois acadêmicos cujos cursos foram importantes para sua crítica, a saber, Marillier e Durkheim: o primeiro, por disponibilizar a ele "sa bibliographie et les notes de ses différents cours, sur le tabou, les rites funéraires, le culte des morts et le mariage"; e o segundo, dentre outras coisas, pelos "cours que j'ai entendus de M. Durkheim, à Bordeaux, sur la peine, la religion et la famille" (MAUSs, 1897, p. 38, n. 2). No caso da pena, como Steinmetz não investigou a função que ela poderia desempenhar nas sociedades ditas primitivas, ele perdeu de vista seu funcionamento também nas sociedades contemporâneas. Dessa maneira, assim como há "dans le droit moderne des restes de la vengeance primitive, de même il doit y avoir dans les types originaires de la réaction juridique quelque chose qui est le germe de notre système pénal" (MAUSs, 1897, p. 35). Ao relacionar a vingança privada como origem da pena pública dos povos ditos civilizados, Steinmetz não apresenta os fatos que provam esta relação e crê, ao contrário, que a pena pública foi desde sua origem como é no direito contemporâneo: racional, consciente e utilitária. Como sua própria definição de direito penal opera a partir de características do direito moderno, Steinmetz perde de vista o funcionamento do direito penal primitivo e, assim, compromete seus resultados. O mesmo acontece com a definição de crime do autor, em que ele considera crime apenas os homicídios, tanto nas sociedades primitivas quanto nas contemporâneas. Esse é o outro problema identificado por Mauss no método de Steinmetz: a falta de definições científicas e, por consequência, o uso de noções comuns dentro da ciência. Ao proceder assim, Steinmetz também projeta uma concepção moderna de crime para outro contexto, em que o homicídio sequer era considerado crime, visto que passou a ser regulado pelo direito penal relativamente tarde. Todavia, de acordo com Mauss, já existiam atos considerados repugnantes pela opinião pública, e a reação a estes atos propiciava, então, a pena. Nesse caso, a pena viria à luz a partir dos fenômenos religiosos. E, nesse sentido, haveria uma origem religiosa para o direito penal público que Steinmetz não foi capaz 
de identificar. Tendo em vista o caráter intempestivo e imediato da pena, a indignação ocorre precisamente porque são violadas "règles obligatoires, senties comme bonnes et nécessaires par tous les membres de la société" (MAUSs, 1897, p. 39). Daí, a análise do funcionamento da reação penal nas sociedades primitivas nos fornece outro ponto de partida para a vingança privada como efeito da natureza religiosa da família, e a pena pública como efeito de interdições rituais. Conforme afirma Mauss: "Une méthode sociologique aboutit donc à attribuer à la peine comme à la vengeance privée une origine religieuse, c'est ce qui nous reste à établir" (MAUSS, 1897, p. 38).

O primeiro ponto de crítica diz respeito ao nexo causal entre a vingança privada e o culto dos mortos. Apesar de reconhecer a estreita relação entre os fenômenos, para Mauss esse é o caso de uma correlação que foi equivocadamente estabelecida como causalidade, uma vez que tanto a vingança familiar quanto os ritos funerários são produtos correspondentes, mas distintos, do caráter religioso da comunidade. A esse respeito, "[1]a solidarité religieuse du clan était le véritable antécédent de la plus grande partie des rites funéraires” (MAUSS, 1897, p. 40). Seja pelo sentimento de solidariedade do grupo, seja pelas crenças animistas, vários outros autores já haviam estabelecido essa unidade. No caso específico da vingança, como nenhuma morte é considerada natural para os indígenas, eles a atribuem à transgressão de alguma interdição ritual ou a algum feitiço advindo de uma tribo vizinha. Nesse sentido, toda morte precisa ser vingada - e não só o homicídio, como supõe Steinmetz. A determinação do culpado pela morte é parte essencial dos ritos funerários, exceto quando a morte resulta de um homicídio praticado por um parente da vítima. Se, por um lado, toda ação externa infligida ao clã gera uma reação, por outro, quando a mesma ocorre dentro do clã não gera nenhuma reação, pois não viola a interdição religiosa: “C'est donc la solidarité du clan vis-à-vis des circonstances extérieures qui cause immédiatement la plupart des cas de vengeance" (MAUSS, 1897, p. 44-45). Portanto, é a família que é vingada, e não o morto: a integridade moral da família é garantida em detrimento de seus membros. Isso ocorre porque, no direito primitivo, a morte é assunto de direito privado e sua relação com o direito público ou religioso é apenas indireta. Ao contrário, o que é tido como divino não é a pessoa, mas o grupo, que é por sua vez cercado de interdições. O sangue da parentela é, assim, tomado como o símbolo religioso da solidariedade do clã, e é contra a violação desse símbolo do clã que a vingança privada reage. Conforme conclui Mauss: 
“La solidarité religieuse du groupe, la sensibilité qu'il éprouve à l'injure faite au sang, sont donc la cause immédiate de la vengeance privée" (MAUSS, 1897, p. 48). Isso seria atestado pelo próprio desenvolvimento da vingança privada, que declina de acordo com o declínio da vida religiosa do clã. Assim, ainda que religiosa, por seu caráter familiar e privado, a vingança não pode ser tida como o tipo primeiro de reação penal pública.

O segundo movimento crítico de Mauss diz respeito à investigação do que poderia ser o equivalente ao funcionamento da pena pública contemporânea, ou seja, a existência de interdições cuja violação acarreta a pena nas "societés les plus elémentaires" (MAUSS, 1897, p. 49). Sabendo que o homicídio, por si só, não atendia a essas especificações, Mauss cita a legislação do tabu polinésio como um conjunto de fatos que poderia esclarecer a origem religiosa da pena das sociedades elementares. Tomando por exemplo os dados relativos à Índia e à Melanésia, Mauss demonstra tanto a forma difusa de sanção quanto o caráter religioso do tabu: nessas sociedades, os tabus regulam desde a entrada e saída de festas e cerimônias mágico-religiosas, até as proibições relativas ao contato com sangue menstrual e a proibição de relação sexual entre parentes do mesmo clã. Em todas essas situações, a repressão ao crime religioso é imediata e difusa, porque atenta contra os sentimentos religiosos que formam o núcleo das regras morais desses grupos. A sanção sempre é dirigida a um indivíduo que viola uma interdição, voluntária ou involuntariamente, e estende-se muitas vezes aos seus pertences e ao resto de sua família, dada a qualidade contagiosa do tabu. O que Steinmetz não havia percebido, portanto, é precisamente o caráter formalista do direito das sociedades primitivas, diretamente ligado à força dos princípios religiosos das sociedades elementares (MAUSS, 1897, p. 55).

Cabe a Mauss, finalmente, explicar a gênese do sistema de interdições rituais que caracteriza a pena pública. Admitindo tratar ainda de um tipo de explicação hipotética e preliminar sobre a origem dessas interdições, Mauss apresenta as linhas gerais de tal origem até o surgimento das sanções difusas:

cette forme du droit on la retrouve partout, le système des interdictions rituelles forme le fond de la vie morale et juridique des sociétés les plus simples. [...] D'abord les interdictions rituelles sont quelquefois sans aucune sanction; d'autres fois les transgressions n'entraînent que des dangers magiques pour celui qui les accomplit. Enfin quand il y a réellement vindicte publique, parce qu'il y a danger public, la répression est, comme dit M. Durkheim, "diffuse” (MAUss, 1897, p. 50; grifo nosso). 
Temos, então, o estabelecimento de ao menos três fases logicamente distintas da origem do sistema de interdições, a saber: i) a fase na qual as regras prescindem de qualquer sanção; ii) a fase na qual as sanções consistem em punições de caráter mágico; iii) e, enfim, a fase na qual emerge a sanção penal difusa, tal qual Durkheim apresentara em De la division du travail social. Na primeira fase, as sanções sequer existem, porque são desnecessárias: segundo as etnografias disponíveis, a ruptura dos tabus sexuais que constituem a regra da exogamia e do tabu do incesto, por exemplo, seriam situações excepcionais. Ao contrário, essas sociedades elementares seguem cegamente essas regras sem se questionar, como se estivessem gravadas em seus instintos, tamanha a força da consciência social sobre os indivíduos:

Peut-être la cause est-elle que le sauvage agit ainsi parce qu'il n'a pas idée d'agir autrement. La conscience sociale lui impose ses prohibitions avec une telle force que l'obéissance est instinctive et aveugle. [...] Chaque démarche de la vie est entourée d'un tel nombre de tabous et de rites absorbants, que ceux-ci pénètrent tellement toute la conduite que l'individu ne les sent plus et agit comme s'ils faisaient partie du système de ses instincts. Tel est encore le fonctionnement actuel du tabou en Mélanésie, par exemple celui du tabou des sangs de la femme : le natif les évite naturellement (MAUSS, 1897, p. 56).

Assim, muito antes do sistema de interdições rituais depender das sanções para funcionar, ele depende fundamentalmente de um processo de educação e inculcamento das regras sociais que, por serem sagradas, são seguidas pelos indivíduos como se estivessem inscritas em sua natureza. No que diz respeito à segunda fase, a partir do momento em que os indígenas começam a atribuir razões para o cumprimento dessas regras, eles então tentam evitar as sanções sobrenaturais. Assim, o ato criminoso “expose immédiatement l'individu aux dangers dont l'imagination entoure la transgression d'une règle sacrée" (MAUSS, 1897, p. 56; grifo nosso). As coisas tabu carregam consigo essa dualidade entre puro e impuro que configuram as coisas sagradas. Segundo a definição de Mauss (1897, p. 59): "Est sacrée toute chose retirée de l'usage commun", isto é, o princípio religioso que é separado e envolto de interdições que regulam sua manipulação. Da mesma maneira, o tabu se opõe a tudo aquilo que é comum e ordinário. E as primeiras regras penais carregam justamente esse caráter contagioso e sagrado do tabu: assim, aquele que toca em coisas tabu automaticamente se contamina e torna-se também tabu; por conseguinte, aquele que viola o tabu está sujeito a sucumbir por morte ou doença. Não raro os mitos sobre a 
origem da morte de diversos povos estão ligados à violação de um tabu. Mas há, também, sujeitos que não sucumbem diante da violação do tabu por serem portadores de poderes mágicos, de “"un mana' supérieur, dirait un Mélanésien”. Portanto, o caráter ambíguo das consequências do tabu advém de sua própria natureza: "il concilie le sacré et l'impur, il fait les dieux comme les criminels" (MAUSS, 1897, p. 57). Do ponto de vista evolucionário, Mauss sustenta que o tabu polinésio seria o fenômeno originário de outra instituição análoga na Roma antiga, qual seja, o sacer. Devido à proibição legal dos encantamentos mágicos, todo cidadão romano poderia matar o sacer e destruir sua propriedade. Assim, "[1]e caractère religieux de la plus ancienne législation pénale de Rome devient évident, ainsi que ses analogies avec le droit le plus primitif. Il y a plus, la consecratio a toujours conservé à Rome le caractère ambigu qu'avait le tabou en Mélanésie" (MAUSS, 1897, p. 59). Segundo Mauss, o desenvolvimento do direito penal romano torna clara a diminuição do papel dos pontífices e da religião em benefício de regras cada vez mais seculares e administrativas. Nisso consiste a evolução do direito criminal, da origem religiosa até o ideal racional do direito contemporâneo: "De la législation du tabou à nos codes, la marche du progrès a été ininterrompue et a consisté à passer des origines religieuses et instinctives à l'idéal rationnel et social où tend notre justice" (MAUSS, 1897, p. 59).

Em uma resenha de Mauss (1898a) sobre o primeiro volume do Année produzida para uma revista de etnografia franco-alemã, é possível notar que ao menos dois movimentos evidentes de sua preocupação fazem parte de seu ensaio crítico sobre Steinmetz. O primeiro deles diz respeito à emergência da ciência moderna, evento que estaria inerentemente ligado à possibilidade de divisão do trabalho intelectual. Seguindo a ideia presente no prefácio de Durkheim a este primeiro volume do Année, Mauss reafirma que é somente "sur le limite des sciences que se font leurs progrès" (MAUSS, 1898a, p. 231). Mas, para isso, seria necessário liberar a sociologia da filosofia e colocar os pesquisadores em contato com os dados primários de pesquisa disponíveis nas mais diversas áreas de ciência social existentes. Esse movimento levaria à consequente perda da imagem unitária e coerente da sociologia em prol do desenvolvimento de áreas especiais que conduzem à especialização profissional: o próprio caso de Mauss, ao tornar-se especialista em religião dos povos não-europeus do Année, exemplifica o exposto. Já o segundo movimento diz respeito à enfatização do papel da etnografia 
como meio privilegiado de estudo das sociedades indígenas. $\mathrm{Na}$ resenha, Mauss apresenta o objetivo da sociologie religieuse, qual seja, o de investigar as estruturas sociais elementares por meio dos documentos etnográficos:

C'est qu'en effet les sociologues doivent attribuer la plus haute importance a l'étude des structures sociales élémentaires, des sociétés dites non-civilisées. Non seulement l'ethnologie générale semble être le premier chapitre de la sociologie, mais les différentes études spéciales des ethnologues sont et seront de plus en plus la préface indispensable des différentes études spéciales des sociologues. N'importe quel fait social doit, avant tout, être étudié sous ses aspects les plus frustes. [...] - Il y a plus, l'ethnographie a aussi, pour les rédacteurs de l'Année, la plus haute importance. La sociologie ne peut être que comparative; et la base des comparaisons sera, connue pour les ethnologues, nécessairement les faits ethnographiques. [...] Et c'est pourquoi, loin de demander des généralités et des interprétations aux ethnographes, il faut leur demander la précision, la critique, la sobriété, telle description froide mais rigoureuse d'un objet de Musée Ethnographique est bien préférable a telle description littéraire et colorée de la vie d'un Kampong Javanais. - Que les ethnographes nous indiquent de nouveaux faits, que les ethnographes nous proposent de nouvelles et plus vastes synthèses, et l'Année Sociologique fera tous ses efforts pour les connaitre et les signaler (MAUSs, 1898a, p. 232; grifo nosso).

Segundo Mauss, o conhecimento obtido pela observação etnográfica está na base do conhecimento sociológico, na medida em que a etnografia permite o acesso privilegiado aos aspectos mais rudimentares dos fenômenos sociais ou, para usar o termo consagrado, às estruturas sociais elementares, presentes em qualquer sociedade. Dessa maneira, as comparações feitas pela sociologia nascente deveriam sempre tomar como modelo de referência e base elementar o conhecimento etnológico. Mas, é importante frisar, não se trata de simplesmente tomar a etnografia disponível como conhecimento, mas de construir, sociologicamente, o conhecimento das formas elementares a partir do material etnográfico. Nesse sentido, as teorias e as interpretações utilizadas pelos etnógrafos devem ser levadas em consideração, mas tanto o aparato teórico quanto os dados deveriam passar, segundo Mauss, pelo crivo da interpretação sociológica. Assim, ao contrário de tomar a diferença dos outros povos como exotismo, caso do Kampong Javanês, cabe à sociologia enfatizar como o conhecimento objetivo dessa diferença pode permitir compreender a vida social das sociedades modernas. 


\subsection{O mecanismo do sacrifício}

No segundo volume do Année, Mauss publica em colaboração com Hubert o "Essai sur la nature et la fonction du sacrifice", precedido por "De la définition des phénomènes religieux" de Durkheim. Conforme atesta a correspondência entre os autores, Durkheim teve um papel editorial ativo na concepção e escrita do trabalho de Hubert e Mauss - sabe-se, por exemplo, que foi Durkheim quem intitulou o ensaio de Hubert e Mauss (DurKheIM, 1998, p. 181). Para além disso, nos interessa que a correspondência em torno do ensaio sobre o sacrifício apresenta "the traces of a conflict of interpretations of ritual sacrifice between the 'master' and his younger colleagues" (PTACEK, 2015, p. 76). Ainda em dezembro de 1897, quando Hubert e Mauss acabavam de decidir pela escrita conjunta do ensaio, Durkheim escreve a Mauss oferecendo diversas sugestões, desde o plano geral do artigo até a maneira pela qual Hubert e Mauss poderiam dividir o trabalho, sempre reafirmando que estas eram "seulement $\grave{a}$ titre consultatif. Vois vous-mêmes" (DuRKHEIM, 1998, p. 91). Em carta de janeiro de 1898, Durkheim lamenta que Mauss tenha sugerido que ele não publicasse o artigo sobre a definição de religião em conjunto com seu ensaio: "Les raisons que tu m'as données [...] ne me semblent pas bien sérieuses. J'y reviendrai” (DURKHEIM, 1998, p. 105). Finalmente, noutra carta de fevereiro de 1898, Durkheim afirma ter decidido publicar conjuntamente seu artigo com o de Mauss e Hubert, alegando que mesmo nas resenhas de Mauss para o Année "le lien entre les faits dont tu parles et l'ordre social n'appraisse pas toujours assez nettement" (DURKHEIM, 1998, p. 108). No entanto, esse aparente desencontro de expectativas sobre a composição de artigos para o segundo volume do periódico revelaria um desencontro ainda mais profundo sobre o que Durkheim esperava do ensaio sobre o sacrifício e aquilo que efetivamente Mauss e Hubert planejaram fazer. Nas cartas de Durkheim entre junho e julho do mesmo ano, o autor explicita aquilo que lhe parecia tanto o coroamento de seus trabalhos anteriores, quanto a grande lacuna nos estudos sobre o sacrifício - que ele esperava que o artigo do sobrinho preenchesse. Para Durkheim, Smith e Frazer haviam equivocadamente

3 As cartas trocadas entre Hubert e Mauss em 1898 (HUBERT, 2012, p. 98-99) indicam uma divisão do trabalho para redigir o ensaio. Coube a Mauss a maior parte do trabalho, tendo este autor escrito as partes consideradas mais gerais do ensaio: Introdução, Conclusão e os itens "I. Définition et unité du système sacrificiel", "II. Le schème du sacrifice" e "III. Comment le schème varie selon les fonctions générales du sacrifice". Já Hubert redigiu os dois seguintes itens: "IV. Comment le schème varie suivant les fonctions spéciales du sacrifice" e "V. Le sacrifice du dieu". 
reduzido a complexa imagem do sacrifício à noção de sacrifício comunal; ao contrário, para Durkheim, havia uma noção de sacrifício oposta e mesmo anterior à comunal, qual seja, a de sacrificio penal (DURKHEIM, 1998, p. 144-145). Conforme resume o autor em carta de julho de 1898 :

Ce serait compléter l'œuvre de ces savants que de faire voir qu'une autre idée, qu'un autre élément entrent dans l'institution sacrificielle, et y joue un rôle capital, c'est l'élément répression, destruction obligatoire, imposition dans le seul but de la destruction. Voilà ce qui me paraît capital et voilà dans quel sens je parle de sacrifice pénal. En un sens, si tu veux, il n'y a que rarement un sacrifice pénal, je ne veux pas m'arrêter à cette question. Mais ce me paraît certain, c'est que l'idée pénale est l'âme de toute une série de sacrifices. Relis-toi : la peine quand elle est ce qu'elle a été si longtemps, une pratique rituelle, est indiscernable du sacrifice. Dire qu'elle a de plus un caractère juridique, c'est la différencier bien faiblement ; car qu'est-ce que ce caractère juridique ? Est-ce que les sacrifices expiatoires ne sont pas dosés, mesurés, proportionnés comme les peines pour les crimes ? Ce sont là des distinctions qui ne me disent rien (DURKHEIM, 1998, p. 162; grifo nosso).

Segundo Durkheim, a grande contribuição que ele esperava do artigo de Mauss e Hubert - e que seria o coroamento de toda sua discussão precedente - seria, justamente, a ênfase nos elementos de repressão e destruição que identificariam o sacrifício com a origem da pena primitiva. Nesse sentido, o emprego da noção de sacrifício penal reforçaria uma característica que, para Durkheim, estaria inscrita na própria noção de sacrifício. Durkheim ainda argumenta, em diversos momentos (DURKHEIM, 1998, p. $144,154,163)$, que o meio de provar essa tese consistiria justamente em explorar a ambiguidade da noção de tabu tal qual desenvolvida previamente por Mauss no ensaio sobre Steinmetz e em algumas resenhas para o Année: segundo Durkheim, a noção de tabu oferecida por Mauss era aquela que melhor serviria para fundamentar a ideia penal por trás do sacrifício, pois permitiria enfatizar os elementos negativos deste último, ligados às noções de interdição, destruição, imolação e obrigação, distanciando-se daqueles elementos positivos do sacrifício enfatizados pelos antropólogos britânicos, como os de contrato e comunhão.

No entanto, o caminho adotado por Hubert e Mauss diferiu dessa expectativa. Mauss evita discordar frontalmente de Durkheim, preferindo esclarecer suas diferenças por meio do próprio desenvolvimento de seu trabalho. Não há, inclusive, nenhuma carta de Mauss que explicite o conflito entre a abordagem dos autores do ensaio sobre o 
sacrifício e as tentativas de interferência de Durkheim no referido texto. O único a dizer algo a respeito é Hubert, em uma carta de 1898 endereçada a Mauss que diz o seguinte:

J'ai longuement causé à Durkheim ce soir et cela m'a fait beaucoup de bien. Nous ne nous sommes pas entendus tout de suite. Parce que nous avions des points de départs différents. Il est parti de l'idée de la peine et nous n'y avions songé que pour l'écarter. Cependant nous étudions beaucoup des choses qu'il rattache à cette idée. J'ai donc commencé par être un peu noyé sous sa philosophie. [...] Durkheim voit d'une façon trop nette, trop formelle la distinction du sacrifice communiel et du sacrifice expiatoire. Je lui ai dit que cette distinction très juste dans l'abstrait ne correspondant pas à la réalité (HUBERT, 2012, p. 101-102).

Conforme atesta o trecho, Hubert reconhece o esforço de Durkheim em contribuir para a discussão, mas é categórico em afirmar que ele e Mauss têm muito mais familiaridade e domínio que Durkheim sobre o tema; que a ideia de pena, ao contrário da expectativa de Durkheim, não tem nenhuma relação com o sacrifício, mesmo o expiatório - sendo apenas aparente, portanto, qualquer semelhança que Durkheim tenta estabelecer a partir de sua própria perspectiva.

Todavia, esse desalinhamento em relação a Durkheim tampouco significava um alinhamento de Mauss com a indologia, área de pesquisa marcadamente influente em sua formação, representada por seu professor e amigo Sylvain Lévi. Não por acaso, o ensaio sobre o sacrifício é baseado fundamentalmente na literatura védica, que ele julgava a mais completa e bem documentada disponível sobre o assunto - o que, certamente, se deve às aulas de Sylvain Lévi. Apesar de considerar a indologia uma área bem organizada e com um sólido conhecimento de seu corpus documental, Mauss mantinha reservas quanto às pretensões científicas de uma área dominada por filólogos - que se limitavam a reconstruir a autenticidade das fontes sem qualquer preocupação explicativa. Nesse sentido, Mauss frequentemente criticava os trabalhos dos indólogos, uma vez que estes enfocavam separadamente ora os mitos, ora os ritos hindus, algo que comprometia a compreensão adequada de certos fenômenos, tal como o sacrifício védico. Contrariando o método filológico empregado pelos indólogos, para Mauss "le rite et le mythe ne peuvent être dissociés qu'abstraitement. [...] Le mythe donne son sens au rite qui lui donne sa realité” (MAUSS, 1899a, p. 245). E todas essas críticas são 
endereçadas também a Lévi, na ocasião da resenha de Mauss sobre o La doctrine du sacrifice chez les Brâhmanas ${ }^{4}$, lançado no mesmo ano que o ensaio de Mauss e Hubert:

Il forme, de plus, un tout achevé en ce sens qu'il est tout ce qu'il veut être : une collection ordonnée de textes des Brâhmanas sur le sacrifice. L'auteur [Lévi] a voulu traiter la question en se cantonnant sur le terrain philologique et il y a réussi. Mais cette méthode n'est pas sains inconvénients. Le livre est sans introduction, sans conclusion, c'est-à-dire, au fond, sans explication ; il ne fait pas pénétrer les profanes dans le monde hindou. De plus, il a le tort d'étudier la théologie du sacrifice en la séparant du rite, alors que les deux choses sont indissolubles. [...] C'est l'inverse de ce qu'a fait M. Hillebrandt, quand, dans son premier ouvrage, il a étudié le rituel en l'abstrayant de la théologie. Les deux ouvrages sont ainsi comme deux fragments disjoints d'un même tout (MAUSS, 1900a, p. 295).

De acordo com Mauss, portanto, o trabalho de Lévi em nada se distingue daqueles dos demais indólogos; em sua visão, pecam todos pelos mesmos vícios e, por essa razão, jamais puderam explicar o funcionamento da instituição sacrifical, mesmo tendo à sua disposição tão rico material. Para Mauss, ao renunciar a qualquer ambição teóricoexplicativa para o sacrifício hindu, Lévi não contribuiu para que os cientistas - profanos - penetrassem no universo sagrado hindu e o compreendessem. Ainda que de maneira modesta e provisória, esta é a tarefa científica a ser executada no ensaio sobre o sacrifício: depreender seu esquema elementar de funcionamento e explicar sua função.

O primeiro passo, então, é justificar o novo empreendimento via demonstração dos limites das teorias anteriores sobre o sacrifício, notadamente aqueles relativos à escola antropológica inglesa. De acordo com Mauss e Hubert, o grande problema das teorias de Smith e Frazer era o de reduzir as múltiplas formas do sacrifício ao postulado da universalidade do totemismo. Além do fato de que o totemismo teve registros somente em determinados povos da Oceania e da América do Norte, quase não havia material sobre os casos de sacrifícios totêmicos, tornando inverificável a hipótese britânica. Além disso, Smith deriva do sacrifício comunal todos os demais tipos de sacrifício, sem apresentar qualquer descrição minuciosa de alguma dessas cerimônias. Portanto, a falha fundamental de Smith era de método: “Au lieu d'analyser dans sa complexité originaire le système du rituel sémitique, il s'est plutôt attaché à grouper généalogiquement les faits d'après les rapports d'analogie qu'il croyait apercevoir entre eux" (HUBERT; MAUSs, 1899, p. 34). Assim como Durkheim, Mauss entende que é impossível e inútil

4 O livro baseou-se nas aulas ministradas por Lévi durante o ano letivo de 1896-1897, no qual Mauss frequentou como aluno. 
tentar elaborar um catálogo completo de todas as ocorrências do fenômeno. Ao contrário, a estratégia proposta é a de estudar em profundidade fatos típicos bem delimitados, tomados principalmente dos Vedas e da Torá, bem como de documentos de segunda mão que relatam sacrifícios gregos e romanos. Ao isolar dois sistemas muito distintos e compará-los, portanto, teríamos acesso às formas elementares da instituição sacrificial.

Após a crítica e a seleção das fontes, cumpre realizar a definição preliminar do fenômeno. Partindo dos fatos designados por sacrifício, a primeira ideia que se impõe é a de consagração. Todo sacrifício implica em uma consagração: um objeto passa do domínio comum, profano, para o domínio propriamente religioso. No entanto, nem toda consagração partilha dos mesmos elementos presentes no rito sacrificial. A unção, por exemplo, é um caso de consagração no qual se esgotam seus efeitos no objeto consagrado. "Dans le sacrifice, au contraire, la consécration rayonne au delà de la chose consacrée ; elle atteint entre autres la personne morale qui fait les frais de la cérémonie" (HuBERT; MAUss, 1899, p. 36-37), que é religiosamente transformada ao elevar-se a um estado de graça ou expiar um pecado. Com efeito, para que o elemento exterior distintivo da consagração no sacrifício esteja presente é necessário que a coisa consagrada sirva de intermediária entre o objeto ou pessoa que deve receber seus efeitos e a divindade à qual o sacrifício é prestado. Esse elemento, porém, ainda não é suficiente, porque não distingue claramente o sacrifício das oferendas. O sacrifício certamente é uma oferenda, cuja finalidade é a destruição da coisa ofertada: a vítima, que é sacrificada na cerimônia. Somente a oferendas desse tipo deve ser reservado o termo sacrifício. E o que as diferencia das demais oferendas são tanto sua gravidade quanto sua eficácia, pois no sacrifício as energias religiosas em jogo são mais intensas e, consequentemente, mais devastadoras (HuBERT; MAUSS, 1899, p. 39). Chega-se, assim, à seguinte definição inicial: "Le sacrifice est un acte religieux qui, par la consécration d'une victime, modifie l'état de la personne morale qui l'accomplit ou de certains objets auxquels elle s'intéresse" (HUBERT; MAUSS, 1899, p. 41). Tal definição exclui do horizonte outras definições de sacrifício, seja pela noção de comunhão, seja pela de expiação; segundo Hubert e Mauss, há uma ambiguidade inerente a todos os sacrifícios, que sempre apresentam algum elemento comunal ou expiatório combinado - não podendo, portanto, servir como base para uma definição rigorosa do fenômeno. Apesar 
da diversidade das práticas sacrificiais, há continuidade entre as formas do sacrifício e mesmo um núcleo comum. Para os autores, a melhor alternativa para depreender esse mecanismo seria estudar uma forma de sacrifício que seja suficientemente complexa, isto é, uma forma em que todos os momentos importantes do drama ritual estejam reunidos. Esse é o caso do sacrifício animal védico, ao mesmo tempo completo e amorfo, não sendo determinado por nenhum sentido específico e servindo para os mais diversos fins.

De maneira esquemática, todo sacrifício demanda ritos de entrada e saída, pois ele só pode ser efetuado por agentes religiosos em um meio religioso. Todavia, antes da cerimônia nem o sacrificante, nem o lugar, nem os instrumentos, e tampouco a vítima possuem esse caráter religioso em grau necessário para o ritual: "Ils sont profanes ; il faut qu'ils changent d'état. Pour cela, des rites sont nécessaires qui les introduisent dans le monde sacré et les y engagent plus ou moins profondément" (HUBERT; MAUSS, 1899, p. 48). Essa primeira etapa, a entrada no sacrifício, consiste na preparação dos agentes e coisas que serão envolvidos na realização do ato sacrificial; essa preparação se dá por meio de uma série de cerimônias simbólicas prévias, tais como purificações e consagrações, que têm por objetivo despojar os agentes e as coisas de seu caráter ordinário ou profano e introduzi-los no mundo sagrado. Tendo preparado todos os componentes da peça, os elementos se organizam em torno do centro gravitacional do sacrifício, a vítima; o rito sacrificial consiste, então, em uma mudança de natureza da vítima que significa ao mesmo tempo seu aniquilamento e sua consagração. Dessa maneira, os ritos praticados sobre a vítima podem ser resumidos pelo seguinte esquema:

On commence par la consacrer; puis les énergies que cette consécration a suscitées et concentrées sur elle, on les fait échapper, les unes vers les êtres du monde sacré, les autres vers les êtres du monde profane. La série d'états par lesquels elle passe pourrait donc être figurée par une courbe : elle s'élève à un degré maximum de religiosité où elle ne reste qu'un instant, et d'où elle redescend ensuite progressivement (HUBERT; MAUSS, 1899, p. 84).

Esse processo é compartilhado pelo sacrificante, que experimenta de maneira atenuada a mesma série de estados da vítima, ou seja, seu estado religioso descreve uma curva simétrica àquela que percorre a vítima. Assim como a entrada, toda essa concentração de energias sagradas que culmina no sacrifício da vítima demanda uma série de ritos de saída para que todos os envolvidos no sacrifício possam voltar ao mundo profano. Esses 
ritos de saída são, por sua vez, simétricos àqueles praticados para a entrada no sacrifício. Dessa maneira, podemos dizer que cada um dos seres e objetos envolvidos no sacrifício são arrastados por um movimento contínuo em direção ao sagrado e ao profano, formando uma curva com inclinações opostas na entrada e na saída. Nesse esquema, temos a curva que descreve a vítima como a que atinge o ponto mais alto. Esse é o esquema concreto do sacrifício animal hindu, que constitui a matéria comum de que são feitas as formas especiais de sacrifício.

A diversidade dos sacrifícios advém, então, das variações possíveis do esquema geral apresentado. Tendo em vista que o objetivo de todo sacrifício é transformar o estado religioso do sacrificante ou do objeto sacrificado, podemos afirmar que as linhas gerais variam de modo a aumentar ou diminuir o grau de sacralidade do sacrificante e da vítima dependendo do estado inicial de cada um na cerimônia. No primeiro caso, temos os chamados sacrifícios de sacralização cuja função consiste em transmitir o caráter sagrado da vítima ao sacrificante ou ao objeto por meio da imolação da primeira: “Pour cela, il fallait l'associer à la victime le plus étroitement possible ; car c'est grâce à la force que la consécration a amassée em elle, qu'il acquiert le caractère désiré" (HuBERT; MAUSS, 1899, p. 90). Dentre suas manifestações, esse conjunto compreende aqueles sacrifícios nos quais se pratica a comunhão alimentar, tal qual descrita por Smith. Já no segundo caso, ao contrário, não raro o sacrificante encontra-se desde o princípio marcado por um estado inicial de pureza ou impureza que é preciso expiar. Nesses casos, classificados como sacrificios de dessacralização, "le caractère sacrée dont le sacrifice opère la transmission va non pas de la victime au sacrifiant, mais, au contraire, du sacrifiant sur la victime. C'est sur elle qu'il se débarrasse" (HuBERT; MAUSS, 1899, p. 94). Tal classificação evidencia uma importante característica dos sacrifícios e da própria natureza dos fenômenos religiosos: primeiro, o puro e o impuro não se excluem e são, antes, aspectos da mesma realidade religiosa; segundo, como não há um sentido predeterminado para a atuação do sagrado, podendo este último ser manipulado tanto para o bem quanto para o mal, evidencia-se a ambiguidade inerente às forças religiosas em ação. Dessa maneira, o que interessa no rito sacrificial é a vítima e a sua capacidade de concentração e irradiação do sagrado.

Apresentadas as variações gerais e especiais que o sacrifício pode ter, Hubert e Mauss passam à análise de outro caso de sacrifício que, por sua complexidade e 
disseminação, permite introduzir a discussão sobre os elementos dinâmicos da instituição sacrificial. Trata-se dos sacrifícios agrários, cuja problemática é sumarizada pelos autores da seguinte maneira:

Ces sacrifices [agraires] ont un double but. Ils sont destinés d'abord à permettre et de travailler la terre et d'utiliser ses produits, en levant les interdictions qui les protègent. En second lieu, ils sont un moyen de fertiliser les champs que l'on cultive et de conserver leur vie quand, après la récolte, ils apparaissent dépouillés et comme morts. Les champs, en effet, et leurs produits sont considérés comme éminemment vivants. Il y a en eux un principe religieux qui sommeille pendant l'hiver, reparait au printemps, se manifeste dans la moisson et la rend, pour cette raison, d'un abord difficile aux mortels. Parfois même, on se représente ce principe comme un esprit qui monte la garde autour des terres et des fruits; il les possède, et c'est cette possession qui constitue leur sainteté. Il faut donc l'éliminer pour que la moisson ou l'usage des fruits soit possible. Mais en même temps, comme il est la vie même du champ, il faut, après l'avoir expulsé, le recréer et le fixer dans la terre dont il fait la fertilité (HuBERT; MAUSS, 1899, p. 106).

O primeiro elemento sobressalente dos sacrifícios agrários consiste no seu movimento ininterrupto de criação e recriação da vida para assegurar a fertilidade da colheita. Tal movimento apresenta sucessivas concentrações e difusões: tão logo a vítima se torna espírito, é partilhada para semear a vida; mas, "[p]our que cette vie ne se perde pas [...] il faut la rassembler périodiquement" (HUBERT; MAUSS, 1899, p. 114), já que o sacrifício agrário contém, em si mesmo, a condição de sua periodicidade estipulada pelos mitos, prescindindo da atividade agrícola. Nesses termos, é por meio do estudo dos sacrifícios agrários e de suas festas que temos acesso a um elemento dinâmico da manifestação periódica de forças religiosas, qual seja: o ritmo da vida coletiva engendrado pela alternância entre concentração e dispersão do sagrado.

Além disso, o sacrifício agrário está na origem de outro tipo de sacrifício no qual o papel da vítima chega ao ápice, qual seja: o sacrifício do deus, forma sacrificial que penetrou nas religiões mais recentes e deu origem a crenças e práticas vivas até hoje. Nesse sentido, o esforço de Hubert e Mauss considera com especial ênfase o papel da mitologia no desenvolvimento do fenômeno em questão. Em determinados sacrifícios agrários, a vítima experimenta uma apoteose que culmina em seu renascimento; sua divinização é uma forma rara de santificação e separação, na qual a vítima concentra o máximo de santidade que o sacrifício personifica. Além disso, para que o sacrifício do deus seja possível, é preciso que toda sua natureza divina personificada seja duradoura, 
o que é garantido pela repetição e peridiocidade das cerimônias: "Cette association indissoluble entre des êtres ou une espèce d'êtres et une vertu surnaturelle est le fruit de la périodicité des sacrifices", que fornece "les éléments de la symbolique divine" (HuBerT; MAUSS, 1899, p. 119-120). Dessa maneira, os dramas sagrados que encerram o sacrifício do deus estão na base do desenvolvimento da mitologia sacrificial, renovando periodicamente a vida legendária dos deuses que dele surgiram. Assim, o sacrifício reaparece na mitologia como a comemoração do sacrifício original do deus, estabelecendo uma afinidade intrínseca entre a vítima e deus: “C'est par le semblable qu'on nourrit le semblable et la victime est la nourriture des dieux. Aussi le sacrifice a-til été rapidement considéré comme la condition même de l'existence divine" (HUBERT; MAUSS, 1899, p. 130). Da mesma maneira, a teologia apropriou-se dos mitos sacrificiais para elaborar a narrativa sobre a origem do mundo e explicar sua criação e, não raro, as cosmogonias estão baseadas em dramas sobre o sacrifício divino. A esse respeito, o desenvolvimento de ritos semelhantes aos do sacrifício agrário estão na origem da concepção do sacrifício do deus único e transcendente da teologia cristã:

le développement de rites, si semblables à ceux du sacrifice agraire, a pu donner naissance à la conception du sacrifice, rédempteur et communiel, du dieu unique et transcendant. Le sacrifice chrétien est, à cet égard, un des plus instructifs que l'on puisse rencontrer dans l'histoire. Nos prêtres cherchent, par les mêmes procédés rituels, à peu près les mêmes effets que nos plus lointains ancêtres. Le mécanisme de la consécration de la messe catholique est, dans les lignes générales, le même que celui des sacrifices hindous. Il nous présente, avec une clarté qui ne laisse rien à désirer, le rythme alternatif de l'expiation et de la communion. L'imagination chrétienne a bâti sur des plans antiques (HUBERT; MAUSS, 1899, p. 131).

Sob essa perspectiva evolucionária, o sistema de sacrifícios agrários que compreendia celebrações dramáticas periódicas e constantes originou a concepção mais abstrata das narrativas míticas que colocam o sacrifício do deus não só na base de diversas cosmogonias distintas, mas também na de tradições religiosas como o cristianismo. Segundo os autores, o sacrifício foi sublimado e conservado na teologia cristã, de tal modo que na missa diária perpetua-se o sacrifício de Cristo. No cristianismo, a eficácia do sacrifício "a été simplement transportée du monde physique au monde moral" (Hubert; MAuss, 1899, p. 130), tornando a ideia de um deus que se sacrifica pelo mundo um símbolo de abnegação irrestrita. 
Assim, apesar da grande variedade de formas nas quais pode se manifestar e de funções que pode cumprir, a unidade do sistema sacrificial reside em seu procedimento invariante, qual seja, o de "établir une communication entre le monde sacré et le monde profane par l'intermédiaire d'une victime, c'est-à-dire d'une chose détruite au cours de la cérémonie" (HUBERT; MAUSS, 1899, p. 133). Nesse sentido, cabe à vítima transmitir o caráter sagrado do mundo religioso ao mundo profano e vice-versa. Uma vez liberada, a alma da vítima torna-se um centro de irradiação de energia. Muito além do sacrificante, "[1] e rite met en mouvement l'ensemble des choses sacrées auxquelles il s'adresse" (HuBERT; MAUSS, 1899, p. 134). Para que o sacrifício seja possível, é preciso que existam coisas fora do sacrificante que estejam próximas o suficiente para que ele possa entrar em relação com elas e extrair do contato estabelecido o benefício que espera dos seus ritos. Segundo Hubert e Mauss (1899, p. 136-137), "ce caractère de pénétration intime et de séparation, d'immanence et de transcendance est, au plus haut degré, distinctif des choses sociales", que também existem ao mesmo tempo dentro e fora do indivíduo. Contra os que pensam que as noções religiosas são um jogo de ilusões, Hubert e Mauss sustentam que, justamente por serem objeto de crença, as noções religiosas existem objetivamente como fatos sociais; por conseguinte, as coisas sagradas pelas quais funciona o sacrifício também são coisas sociais.

Há, portanto, uma dimensão social, ao mesmo tempo imanente e transcendente, que fundamenta a existência da instituição do sacrifício. Por um lado, o ato de abnegação implicado em qualquer sacrifício alimenta a existência ideal das forças coletivas. Mais especificamente, esse conjunto de consagrações, comunhões e mesmo expiações “donnent ou renouvellent périodiquement à la collectivité, représentée par ses dieux, ce caractère bon, fort, grave, terrible, qui est un des traits essentiels de toute personnalité sociale" (Hubert; MAuss, 1899, p. 137). Por outro lado, os indivíduos também usufruem de vantagens desse mesmo ato ao conferirem legitimidade social às coisas que particularmente os interessam: cercam de santidade a si mesmos, seu grupo e seus bens; expiam a maldição mantendo a norma social, de maneira a evitar tanto o perigo para os indivíduos quanto o prejuízo para a coletividade. Dessa maneira, é possível observar como o sacrifício "peut suivre et reproduire à la fois le rythme de la vie humaine et celui de la nature" (HuBERT; MAUSS, 1899, p. 137). 
Em suma, o sacrifício é um fenômeno religioso elementar que está na origem das crenças e práticas religiosas que se desenvolveram e existem até hoje. Não obstante, seus meios de ação são puramente ideais: "tout se passe ici dans le monde des idées, et c'est d'énergies mentales et morales qu'il est question" (HuBERT; MAUSS, 1899, p. 137). Isso esclarece um aspecto central do sacrifício e da natureza dos fenômenos religiosos, a saber, a transformação religiosa de coisas e pessoas por meio do contato com as forças sagradas: o fiel que consagrou a vítima no sacrifício não é mais o mesmo no final da operação, pois “acquis un caractère religieux qu'il n'avait pas, ou il s'est débarrassé d'un caractère défavorable dont il était affligé ; [...] il est religieusement transformé" (HUBERT; MAUSS, 1899, p. 15-16; grifo nosso). Ainda assim, essa transformação depende de uma forma específica para ser eficaz. Em uma resenha de 1898 sobre literatura ritual védica, Mauss já sustentava que a forma característica do sacrifício era a de um drama:"[1]e sacrifice est un véritable drame, chaque instant ayant son prête spécial, chaque prête de sa mélodie et sa prosodie, qui n'a pu être ainsi fixée que par une longue évolution religieuse" (MAUSS, 1898b, p. 232). Portanto, o caráter transformador ideal dos estados religiosos em geral - e dos sacrifícios em particular - é realizado por meio de uma complexa combinação de ritos e mitos, atuação e narrativa, isto é, por uma dramatização, na qual o ritual reencena partes do mito e este, por sua vez, remonta a um ritual original.

\subsection{Da crítica etnográfica às formas elementares da vida religiosa}

O período subsequente ao ensaio sobre o sacrifício compreende dois eventos importantes para a sociologie religieuse. O primeiro foi a publicação, em 1899, de The Native Tribes of Central Australia, de Walter Baldwin Spencer e Francis James Gillen; e o segundo foi a nomeação de Mauss para a cadeira de "Histoire des religions des peuples non civilisés" da EPHE em 1902, acarretada pela morte precoce de Léon Marillier. Em sua aula inaugural na EPHE, Mauss (1902a) intenta apresentar o estado da arte da disciplina de história comparada das religiões primitivas e propor os procedimentos científicos que ele considera mais apropriados para a ciência comparada das religiões. Ambos os eventos oferecem a possibilidade de Mauss apresentar-se como especialista no que Durkheim denominou como etnografia religiosa (DURKHEIM, 1998, 
p. 294) e, dessa maneira, disseminar a proposta de uma sociologia comparada das religiões elementares.

De acordo com Mauss, foi a escola antropológica britânica de ciência comparada das religiões - iniciada por Edward Tylor, John Mac Lennan e Andrew Lang e continuada por Smith e Frazer - que teve o mérito de esboçar os problemas a serem investigados e propor um método para tal. Segundo Mauss, em uma resenha de 1898 sobre a obra de Frank Jevons, eles foram responsáveis por “introduire l'étude des religions primitives dans le cadre des anciennes études historiques, philologiques et folkloristes" (MAUSS, 1898c, p. 161). Entretanto, se os antropólogos britânicos tiveram o mérito de estabelecer uma espécie de identidade entre religiões primitivas e religiões antigas de povos europeus, a escola antropológica britânica é criticada por Mauss por ser cientificamente vaga e reproduzir certos vícios que comprometem suas análises ${ }^{5}$. Na mesma resenha do livro de Jevons, é possível identificar o núcleo da crítica de Mauss à proposta científica da escola antropológica britânica:

L'anthropologie est une science vague, sans grande précision, où la comparaison n'est pas gouvernée par des canons rigoureux, où la recherche du fait contraire n'est nullement capitale. L'étude des concordances est tout, celle des différences est secondaire. Il y a à cela une raison : l'anthropologie est une branche de la psychologie individuelle; la méthode de la religion comparée est donc du même genre. Il s'agit toujours de retrouver les processus mentaux individuels qui sont à la base des faits [...] La découverte des principes psychiques épuise la recherche et l'explication. Quand on a rapproché les règles du tabou et les lois de l'association des idées, quand on a rapporté l'origine des cultes et de la magie à une notion primitive de la causalité, le but est atteint. Un certain intellectualisme est le principe caché de cette méthode. Les actions de l'homme sont censées dépendre de ses vues sur le monde. Ce n'est pas par les besoins sociaux, ni par les institutions concomitantes qu'on explique la forme des phénomènes religieux, mais par des conceptions tout individuelles. Je sais bien que R. Smith a fait la part plus grande aux rites qu'aux croyances, que M. Frazer a ambitionné surtout de constituer une science des rites. Mais toujours et partout [...] ce sont encore les idées qui gouvernent tout (MAUSS, 1898c, p. 161-162; grifo nosso).

Dessa maneira, Mauss critica a psicologia individual que estaria na base do método desses autores, bem como a tendência desses autores em reportar os fenômenos religiosos a certos princípios psicológicos primitivos que seriam partilhados por todos

5 A pedido de Marillier, Mauss planejava escrever um ensaio crítico sobre as teorias da escola britânica, mas o projeto jamais foi concretizado (cf. DURKHEIM, 1998, p. 138-139; MAUSS, 2012, p. 133). 
os humanos. Além disso, Mauss identifica que o princípio norteador que caracteriza todos esses trabalhos consiste no intelectualismo presente no método utilizado pelos autores, método este que tem como pressuposto a primazia das ideias no domínio de todas as ações - mesmo quando se recorre, como é o caso de Smith e Frazer, à análise dos ritos.

Marillier $^{6}$, por sua vez, partilhava com os antropólogos ingleses da explicação psicológica dos fenômenos religiosos. A despeito disso, Mauss exalta sua personalidade científica, verdadeiramente crítica diante de fatos e teorias que julgava mal fundamentadas. Esse foi o caso do totemismo: sendo cético quanto à possibilidade de existir qualquer sociedade verdadeiramente totêmica, Marillier reagiu contra a exagerada relevância que os antropólogos britânicos atribuíam a esse tipo de culto (MAUSS, 1902a, p. 40); ao contrário, o autor argumenta que as formas primitivas da religião poderiam ser reduzidas a um único elemento, enfatizando a complexidade e a variedade das formas religiosas arcaicas (MAUSS, 1898d, p. 204). Mauss, por sua vez, reconhece que a falta de uma definição clara da noção de totemismo levou boa parte desses antropólogos britânicos a nomearem como totemismo qualquer culto teriomórfico de que tivessem notícia. Mauss também é crítico à concepção de religião de Marillier, por procurar a essência da religião em uma instância emocional exclusivamente individual e pré-social, que seria logicamente anterior a qualquer rito ou crença estabelecida socialmente. Para Mauss, não há "une chose, une essence, appelée Religion; il n'y a que des phénomènes religieux, plus ou moins agrégés en des systèmes qu'on appelle des religions et qui ont une existence historique définie" (MAUSS, 1904b, p. 200). Diferentemente de Marillier, para Mauss (1902b, p. 195-197) não há notícia de qualquer forma de vida religiosa na qual as noções de rito e mito estejam ausentes, pois são crenças e atos estabelecidos previamente pelo grupo que se impõem mecanicamente às consciências individuais - ou seja, uma obrigação lógica, que "n’implique pas [...] un système régulier de sanctions pénales” (MAUSS, 1902b, p. 196). Mauss afirma que mesmo esses estados de emoção e de alucinação que encontramos entre os povos americanos e australianos não tinham nada de individuais e eram, na verdade, coletivos: opondo-se a Marillier, Mauss afirma que somente os estados de emoção e êxtase que são coletivos têm a capacidade de interferir e até mesmo de transformar as formas de

6 Para um panorama da vida e obra de Marillier enfocando seus esforços para a institucionalização da psicologia, cf. Le Maléfan (2005). 
agir e pensar de uma coletividade ou instituição. Dessa maneira, "n'est-ce que sous sa forme collective que l'émotion est vraiment apte à modifier le rite et le dogme. La transformation des croyances d'une Eglise est [...] non pas l'oeuvre des individus, mais de l'Eglise même sur laquelle ils agissent" (MAUSS, 1902b, p. 196). Apesar das críticas, Mauss reconhece que a grande expertise de Marillier era a de crítica dos fatos etnográficos, ou seja, a de cruzar informações de diferentes nativos e etnógrafos em busca de revisar não só os fatos por estes apresentados, mas muitas vezes suas próprias teorias (MAUSS, 1902a, p. 41). Para Mauss, Marillier era sobretudo um classificador de fatos, muito mais preocupado com a clareza e a precisão das informações obtidas que com sua explicação (MAUSS, 1902a, p. 42). Contra a psicologia individual de Marillier e da escola antropológica britânica, Mauss defende que somente quando conectarmos os fenômenos religiosos ao seu substrato social poderemos conhecer objetivamente sua verdadeira fisionomia e função (MAUSS, 1898c, p. 162).

Esclarecida sua posição em relação à herança de Marillier, Mauss procura estabelecer em que sentido a verdadeira fisionomia dos fenômenos religiosos só poderia ser dada por seu substrato social. Ele começa por problematizar o título da cadeira que acabara de assumir: o nome "Histoire des religions des peuples non civilisés" sugere uma distinção entre povos civilizados e não civilizados, tal qual aquela entre Kulturvölker e Naturvölker. Da perspectiva de Mauss, não há povo que não partilhe uma língua, um habitat, uma economia, uma religião, um direito ou uma arte; por conseguinte, “il n'existe pas de peuples non civilisés. Il n'existe que des peuples de civilisations différentes" (MAUSS, 1902a, p. 43). Ainda assim, haveria uma maneira de distinguir esses grupos humanos a partir de uma perspectiva evolucionária, levando em consideração o tamanho e o grau de elementaridade de sua organização social, tal como o caso "des petits groupes sociaux, peu denses, à habitats restreints même quand ils sont nomades, à techniques peu perfectionnés, à systèmes juridique, familial, religieux, économique, suffisamment élémentaires" (MAUSs, 1902a, p. 44). A esse respeito, Mauss lamenta o extermínio dos tasmanianos - provocado pelo contato colonial com os europeus - pois estes eram "les derniers représentants, actuels, vivants, de la civilisation paléolithique, celle de la pierre non taillée” (MAUSS, 1902a, p. 45). Ainda assim, era possível encontrar manifestações de religiões elementares em sociedades localizadas na

7 O nome da cadeira faz referência ao livro de mesmo título de Albert Réville, fundador da seção de ciências da religião da EHPE. 
América, na África, na Ásia e na Oceania - áreas em que Mauss pretendia acompanhar a etnografia religiosa disponível para seus cursos na EPHE e resenhas no Année.

Disso sucede a questão acerca do que são esses fenômenos religiosos elementares e de como reconhecê-los, para então poder proceder à sua observação e explicação. Fazendo referência a Descartes, Mauss designa como elementar o fenômeno cuja natureza é mais simples e mais acessível conhecer; mas pondera que os fenômenos religiosos elementares desses povos têm justamente a fama oposta, isto é, não são simples e tampouco fáceis de conhecer (MAUSS, 1902a, p. 46). Essa ideia de simplicidade é caracterizada por Mauss por meio de uma analogia entre a classificação genealógica de organismos policelulares por espécies e a classificação de fatos etnográficos em sociologia:

Je dois donc vous expliquer d'abord dans quelle mesure ils sont simples. Permettez-moi une comparaison. Vous savez, messieurs, que de toutes les plantes et de tous les animaux polycellulaires des époques primaires et secondaires aucune espèce n'a survécu. Mais, vous le savez, elles ont des sortes de représentants dans des espèces encore actuelles. Certes ces espèces ont derrière elles une aussi longue évolution, plus longue même, que certaines espèces de mammifères, par exemple. Mais leur rameau généalogique est branché beaucoup plus bas. Si elles ne sont pas elles-mêmes des organismes simples, elles représentent, mieux que d'autres espèces, des organismes simples dont elles dérivent plus immédiatement. De même, Messieurs, en matière d'ethnographie. Les phénomènes religieux que nous observons actuellement en Australie par exemple ne sont certainement ni simples ni primitifs. Les sociétés australiennes ou américaines ont toutes, derrière elles, une longue histoire. Elles sont aussi vieilles que les nôtres, plus vieilles peut-être, s'il est vrai, ce qui est malheureusement fort douteux, que l'on ait trouvé, en Amérique et en Australie, des traces de l'homme tertiaire. Mais elles sont restées d'espèces plus simples que nos sociétés (MAUSs, 1902a, p. 46-47; grifo nosso).

Dessa maneira, a noção de simplicidade para a análise de sociedades, emprestada da biologia, compreende duas considerações aparentemente contraditórias: a de que os povos americanos e australianos não são literalmente primitivos, uma vez que possuem uma história e são tão antigos quantos os povos europeus; e a de que, ainda assim, em termos comparativos, tais modos de organização social permanecem mais simples que aqueles das sociedades europeias. Desse ponto de vista evolucionário, o que é simples se opõe não àquilo que é complexo, mas antes ao que é composto: poderíamos dizer que o simples é desprovido de ornamentos dispensáveis, acessórios e, portanto, que é elementar, ou seja, não possui elementos que embaraçam sua compreensão. É nesse 
sentido que, para Mauss, as sociedades australianas constituem um tipo mais simples e acessível de conhecer que as sociedades europeias: estas últimas são de um outro tipo cuja história e tamanho imbricaram tantos elementos acessórios que obstruem aquilo que a sociologia comparada das religiões visa conhecer, isto é, a natureza elementar das crenças e práticas religiosas. Na introdução à seção de sociologie religieuse do quinto volume do Année, Hubert e Mauss (1902) acabam por criar uma subseção específica para tratar desses sistemas religiosos, intitulada "Formes élémentaires de la vie religieuse". Essa subseção compreendia, em perspectiva evolucionária, as organizações religiosas elementares, bem como o conjunto de crenças e práticas religiosas em transformação dessas sociedades. Considerando, por exemplo, o totemismo, Hubert e Mauss justificam que, no princípio, essas crenças e práticas religiosas totêmicas manifestam-se de maneira unitária, uma vez que

la notion que le groupe social a de lui-même est donné par le mythe totémique dont le rite n'est, en général, que la représentation dramatique. Notre plan respectera donc la confusion primitive des faits, point de départ de l'évolution (HUBERT; MAUSS, 1902, p. 190).

Nesse sentido, os Arunta australianos ilustram o apontamento feito por Hubert e Mauss: sua organização baseada em clãs totêmicos nada tem de primitiva, pois se trata de uma uma organização totêmica em decomposição, em vias de se transformar em uma confraria de mágicos (MAUSS, 1902a, p. 47). Apesar disso, a regra arunta de filiação não seria determinada pelo vínculo de sangue com os pais, mas pelo totem do espírito que a criança encarna. Mais especificamente, a criança, ao nascer, herda o objeto sagrado, a churinga, que, por sua vez, representa a alma de um ancestral. Esse ancestral retorna ao mundo na ocasião do nascimento da criança e empresta-lhe o nome. Dessa maneira, o nascimento de uma pessoa entre os Arunta seria, ao menos em parte, um fenômeno mágico-religioso. Assim, configura-se como uma das tarefas mais importantes “examiner constamment dans quelle mesure les faits que nous étudierons no permettent de remonter aux formes vraiment élémentaires des phénomènes” (MAUSS, 1902a, p. 48).

Os debates em torno do totemismo dos povos australianos se intensificaram a partir das publicações de Spencer e Gillen (1899 e 1904). Frazer, por exemplo, modificou significativamente sua teoria sobre o totemismo: antes de Spencer e Gillen, esta era baseada na observância de interdições alimentares e matrimoniais; depois das 
publicações dos etnógrafos, cada grupo totêmico seria definido por deter poderes mágicos sobre todos os seres de determinado departamento da natureza, e estaria sujeito às interdições que estes seres carregam. Frazer crê na primitividade e na função essencialmente mágica do totemismo $\operatorname{arunta}^{8}$, e as observações etnográficas confirmavam que esses grupos totêmicos não eram senão confrarias de mágicos (MAUSS, 1900b, p. 218). Nesse modelo, no qual religião e magia são considerados princípios de pensamento e ação opostos, a religião sucederia a magia após esta ser contradita por experiências malsucedidas de manipulação do princípio mágico de causalidade pelos nativos. Para além da já mencionada crítica à abordagem intelectualista de Frazer, Mauss contra-argumenta que seria equivocado classificar os ritos arunta como puramente mágicos, pois nesses ritos também estariam imbricadas as coisas sagradas e interditas, caracteristicamente religiosas. Conforme conclui em sua resenha sobre a nova edição de The Golden Bough: “M. F. n'est arrivé, croyons-nous, à sa theorie de la magie, que par suite d'une définition insuffisante des phénomènes religieux" (MAUSS, 1902c, p. 213). Além de destacar a insuficiente definição de fenômeno religioso, Mauss também mantém reservas à interpretação de Frazer em considerar o totemismo arunta como um fenômeno primitivo. Sendo o totemismo um sistema religioso baseado em uma organização social composta por clãs, Mauss verifica que o caso arunta é composto por confrarias religiosas independentes da organização familiar dos clãs: "suivant les expressions de MM. Spencer et Gillen, [...] le totémisme de ces tribus n'aurait pas de 'côté social', il n'autait qu'une fonction religieuse" (MAUSs, 1900c, p. 206). Isso o leva a questionar, então, se as etnografias sobre os Arunta realmente tratam de um fenômeno primitivo, como afirmam fazer, ou de possíveis sobrevivências tardias desse sistema elementar em decomposição (MAUSS, 1905a, p. 236). Como os próprios etnógrafos reconhecem que mudanças estavam ocorrendo nos costumes e cerimônias arunta, Mauss afirma ser muito provável que “chez Aruntas, nous nous trouvions en présence d'un état secondaire et non primaire", em que "l'organisation totémique, s'accentuant de plus en plus sur le terrain religieux, aurait abandonné tout à fait le terrain familial, et aurait cessé de caractérizer le clan" (MAUSS, 1900c, p. 214).

8 Frazer sustentava que o totemismo arunta era de fato primitivo, dentre outros fatores, pela relativa escassez de recursos materiais desses grupos da Austrália central em relação aos da costa (MAUSS, 1907a, p. 225-226). 
Nesse sentido, os Arunta organizam o intichiuma, cerimônias religiosas anuais que têm por objetivo garantir a prosperidade do animal ou da planta que empresta o nome ao totem. Nessas cerimônias, os membros realizam ritos simpáticos que imitam certos detalhes desses seres totêmicos; no fim, há um sacramento totêmico, rito em que os membros do grupo comem solenemente o animal ou planta correspondente a seu próprio totem, considerado sagrado; esse ato remonta aos tempos imemoriais do alcheringa, mito em que os ancestrais arunta comiam os totens livremente. A essa cerimônia principal, duas outras ligam-se de maneira mais ou menos estreita. A primeira consiste no conjunto de crenças e práticas classificadas por Spencer e Gillen como casos de totemismo individual, isto é, ritos de manejo do objeto portador do totem de cada indivíduo, a churinga. Tal objeto representa o ancestral que o indivíduo encarna e, ao mesmo tempo, a alma de seu antigo proprietário. Todavia, essa espécie de alma exterior que é a churinga não recebeu a devida atenção dos etnógrafos, pois o termo churinga significa, pura e simplesmente, sagrado. Dessa maneira, Mauss afirma que as churingas "se rattachent aussi au centre totémique de la vie du groupe et à son passé mythique ; enfin, ils représentent plus que l'individu vivant, ils contiennent une parcelle d'esprit de toute la série d'ancêtres réincarnés" (MAUSS, 1900c, p. 209). Já a segunda série de ritos diz respeito às cerimônias de iniciação realizadas pelo grupo local - e não pelo grupo totêmico -, baseadas em provações físicas impostas ao jovem iniciado tais como a extração de dentes, a circuncisão e outros tipos de incisões corporais que têm por objetivo dotar o jovem iniciado das qualidades exigidas pelo grupo para, assim, tornarse apto a participar da vida religiosa. Nesse sentido, tanto as cerimônias de iniciação quanto aquelas do intichiuma "sont, au fond, dominées par le mythe totémique. Toutes, elles ont pour but de figurer les actes mythiques des êtres totémiques antiques. Elles sont la mise en action des mythes" (MAUSS, 1900c, p. 212). Mais precisamente, essas cerimônias sagradas "n'étaient que la figuration dramatique de l'histoire des ancêtres des diffétents groupes totémiques présents [...] Les chants racontent l'histoire que le rite agit” (MAUSS, 1900c, p. 211-212). Por conseguinte, o foco na relação entre rito e mito permitiu a Mauss depreender o papel central da representação dramática ou figurada nas cerimônias religiosas dos povos australianos, uma vez que estes ainda não haviam “dépassé le stade où tout était encore mélangé” e a representação dramática compreendia de uma só vez "les éléments de comique, d'esthétique, de sérieux, 
d'historique, et de substantiel que l'évolution répartira plus tard" (MAUSS, 1907c, p. 227). Na resenha da obra seguinte de Spencer e Gillen (1904) sobre os povos australianos do norte, Mauss reconhece a contribuição dos etnógrafos até mesmo à sociologia estética, uma vez que "ils apportent une excellente théorie des représentations figurées dans toute cette partie de la civilisation australienne. Ils élucident en particulier la question du symbolisme des dessins totémiques" (MAUSS, 1905b, p. 251). Haveria, portanto, uma espécie de simbolização particular às cerimônias religiosas elementares, na qual as noções de drama e de figuração desempenhariam um papel central. Conforme Mauss observa em outra resenha:

Par suite de cette nécessité où se trouve le mythe de s'exprimer en idéogrammes rituels, il se crée un certain nombre de symboles qui sont de véritables écritures conventionnelles désignant les dieux. Nous saisissons donc ici un moment de l'évolution mythologique où, contrairement à ce que l'on rencontre dans d'autres sociétés, le signe est relativement indépendant de la chose signifiée ; il n'est qu'un moyen d'évocation ; il n'est plus le dieu, la force religieuse (MAUSS, 1903c, p. 251; grifo nosso).

Nesse contexto, a figuração não seria mais que a necessidade de expressão simbólica dos mitos por meio de ideogramas rituais. A respeito desse processo de simbolização, Mauss ainda destaca duas diretrizes mais gerais: $1^{\text {a }}$ ) "la signification de tel ou tel trait, de telle ou telle colouer n'est pas unique; elle varie suivant les autres signes associés", uma vez que "[1]es valeurs des signes sonts donc multiples"; $2^{a}$ ) consequentemente, "le rapport des diverses représentations est éminemment synthétique", pois "[c]e qui est représenté, c'est le tout; le sens des parties du dessin symbolique n'est fixé que par rapport à l'ensemble de l'événement mythique représenté" (MAUSS, 1903c, p. 252). Dessa maneira, o processo de simbolização dessas sociedades possui um padrão de associação de signos cujas partes fazem referência a um todo que pode ser apreendido pela pesquisa científica, ainda que tais operações simbólicas não se baseiem nos mesmos padrões de associação e de conteúdo que as sociedades modernas apresentam.

Em resenha acerca da etnografia seguinte de Spencer e Gillen (1904), Mauss observa outra peculiaridade sobre os Warramunga, cujos dramas rituais "dénotent un état d'âme collectif d'une étrange intensité" (MAUSS, 1905b, p. 250), como atestavam as fotografias dos ritos funerários desse grupo. Comentando ainda sobre o drama totêmico warramunga de adoração ao totem, Mauss reconhece que também nessa cerimônia tudo ocorre "dans une excitation collective extraordinaire, avec des danses, des chants, des 
échanges de femmes effrénés" (MAUSS, 1905b, p. 247). Esses estados de excitação ou êxtase coletivos provocados pelo conjunto de práticas rituais consistem em um dos elementos mais relevantes do processo de figuração religiosa. Em outra resenha de 1902, Mauss já havia observado que o êxtase era um fenômeno coletivo generalizado nas sociedades indígenas do continente americano e da Oceania, constituindo, por essa razão, um dos fenômenos fundamentais da vida religiosa (MAUSS, 1902d, p. 199). Em uma das raras explanações sobre o tema, ao resenhar uma obra dedicada ao fenômeno do êxtase religioso, Mauss (1903a) reflete sobre como elaborar uma noção sociológica do fenômeno e, ainda, pensar na relação entre as dimensões coletiva e individual a ele associadas. Dentre os efeitos sociologicamente relevantes, o êxtase é um reconhecido tópico quanto aos chamados estados de multidão exemplificados por revoluções, cruzadas, etc. Já do ponto de vista religioso, o êxtase é o objetivo de uma série de ritos, pois é responsável pelo "transport de l'individu au-delà de soi-même, dans lequel consiste tout état vraiment religieux" (MAUSS, 1903a, p. 178). Como bem exemplificam as cerimônias de iniciação, Mauss argumenta que seria a sociedade a responsável por oferecer as condições para o êxtase:

l'espèce humaine n'est pas objet de représentation chez la plupart des extatiques, au contraire les notions collectives, religieuses ou autres, sont le propre but du transport mystique. Si nous laissons de côté les phénomènes physiologiques, nous dirons que l'individu, dans l'extase, se conforme à la société et non pas à l'espèce. Il poursuit des buts transcendants, mais que le groupe lui fixe : telle, par exemple, l'obtention des pouvoirs magiques. [...] - Il y a dans ce caractère de l'extase quelque chose de si essentiel, que c'est lui qui explique comment les rêves et les pratiques extatiques ont été, dans bon nombre de sociétés, un élément essentiel de l'initiation. Celle-ci marque le moment de la pleine sociabilité du jeune homme. Il n'est réputé capable d'être initié que lorsque, au cours de pérégrinations solitaires, de jeûnes, d'observances multiples, il aperçoit, pendent un rêve extatique, son totem individuel, ses génies familiers, son dieu personnel. Son entrée en extase se confond avec son entrée dans la société. Lui aussi le don, comme ses prédécesseurs dans la société des mâles. C'est peut-être aussi l'extase qui explique presque tout le thème fondamental des rites d'initiation. [...] L'initiation est le plus souvent un simple drame de mise à mort figurée, de sommeil, de réveil du jeune homme qui est réputé avoir accédé à une nouvelle vie. Ce départ de l'âme, cette vie supérieure du jeune initié, toutes ces croyances mises en action n'ont-elles pas emprunté à la série de divers moments des états extatiques (MAUSS, 1903a, p. 179-180; grifo nosso). 
No caso das cerimônias de iniciação, Mauss observa que o êxtase serve como um meio indispensável para a figuração dramática da morte do iniciado e de sua consequente obtenção de uma nova alma. A entrada simultânea no êxtase e na sociedade revelaria, então, uma correlação profunda entre esses estados de êxtase e os processos de socialização ou inculcamento dos elementos necessários para o jovem tornar-se pessoa para o grupo, isto é, ser reconhecido como um membro da sociedade. Dessa maneira, as representações ou ideias coletivas, como as religiosas, são os objetos mobilizados durante os estados de êxtase ritual para conformar o indivíduo a objetos transcendentes, mas que são, ao mesmo tempo, fixados pela sociedade. Sendo o êxtase um fenômeno de sugestão, ele pressupõe justamente um conjunto de pessoas em contato, bem como um caráter de contágio e epidemia, que são característicos dessas cerimônias religiosas elementares. Isso leva Mauss a questionar se o êxtase coletivo experimentado por esses grupos não seria mais frequente e mesmo de uma intensidade muito maior do que aquela da qual os europeus têm notícia, "car il est évident que, tant dans sa nature que sans ses effets, l'extase en commun, avec ses hallucinations partagées, peut avoir une tout autre force que l'extase individuel” (MAUSS, 1903a, p. 180). Por essa razão, as manifestações modernas do êxtase coletivo são consideradas "formes cadavérisées et pauvres", ao passo que nas sociedades elementares, onde os fenômenos "sont plus complexes et plus riches, qu'il faut rechercher les faits qui expliquent les origines et qui sont collectifs" (HUBERT; MAUSS, 1904, p. 132).

Outra consequência do estado de decomposição do totemismo que merece a atenção de Mauss diz respeito à emergência do culto a personalidades míticas entre os povos australianos. Mauss chama a atenção para os Warramunga, cuja cerimônia totêmica era dedicada ao culto de um espírito mítico pessoal, a serpente Wollunqua. Apesar de ser o ancestral totêmico do grupo, é considerado indivíduo definido e não espécie animal; os membros do clã são seus descendentes diretos e não sua reencarnação. Sendo assim, a cerimônia para Wollunqua não tem por objetivo a reprodução da espécie totêmica, considerada um ser terrível, único e eterno; mas é, antes, uma adoração de sua personalidade por meio de sua representação com terra, plumas e desenhos, cujo objetivo é sobretudo mantê-la tranquila e satisfazê-la. Nesse sentido, Wollunqua é considerado "maître du temps et du tonnerre et ressemble déjà à une espèce de grand dieu de la tribu" (MAUSS, 1905a, p. 247). Essa e outras personalidades míticas, 
chamadas de grandes deuses australianos, no entanto, não guardavam qualquer relação com os preceitos morais das tribos e dos clãs. Ainda assim, há uma série de representações míticas australianas de mesmo tipo, como a alcheringa dos Arunta e a mura mura dos Dieri, "qui prend une singulière extension et qui semble primer grands dieux" (MAUSS, 1906, p. 180). De acordo com Mauss, essa é uma oportunidade de verificar a hipótese da transição de uma religião que se endereça a coisas materiais, como o totemismo, em direção ao culto de um ser pessoal e sua consequente deificação - algo que poderia servir, inclusive, como modelo para analisar processos de transição de outras religiões em outros contextos.

Ainda assim, Mauss não poupa críticas às etnografias de Spencer e Gillen, por estas últimas apresentarem certas limitações quanto à documentação e à interpretação. De maneira geral, os problemas documentais dizem respeito ao tratamento sumário da mitologia australiana: além da falta de detalhes envolvendo a maioria dos mitos mencionados, não havia um relato sequer dos cantos ou das preces entoadas nas grandes cerimônias; nem mesmo "un récit complet, traduit de la langue arunta, des faits et gestes d'un groupe quelconque d'ancêtres de l'alcheringa" (MAUSS, 1900c, p. 214). Já os problemas de interpretação advêm da visão cronológica das tradições observadas pelos etnógrafos, que incorrem no erro de interpretar a interdição de matar e comer o totem como historicamente recente. Nesse caso, a alcheringa é particularmente elucidativa, precisamente porque esse mito não diz respeito à vida ordinária dos ancestrais, mas antes à vida ritual dos vivos; é porque os vivos comem o totem nos dias de festa que seus ancestrais também o faziam (MAUSS, 1900c, p. 215). Mauss critica abertamente essa abordagem dos mitos feita pelos etnógrafos, pois eles tentariam enquadrar cronologicamente classificações sociais que, na realidade, são estabelecidas logicamente (MAUSS, 1905b, p. 249-250). Nesse caso, o mito não é um registro histórico do passado arunta, mas antes um quadro de referência para a realização periódica da refeição ritual por seus membros. Mas há, ainda, outra razão, além da que se refere à identificação mágica com o totem, para que esse sacramento totêmico se realize: os membros do grupo devem comer ritualmente seu próprio totem para permitir, assim, que pessoas de outros grupos possam comê-lo ordinariamente; ou seja, eles sacralizam para si a espécie totêmica ao mesmo tempo que a dessacralizam para os demais grupos (MAUSS, 1900c, p. 215). Com efeito, todas essas considerações levam 
Mauss a questionar a própria noção de totemismo em voga nos trabalhos em questão, tendo em vista que "à la base de tous ces cultes et toutes ces croyances, il y a non pas la notion étroite et trop restreinte du totem, mais la notion du sacré et l'action magique et religieuse" (MAUSS, 1900c, p. 215). Por serem objeto de respeito religioso e separadas do mundo profano, tanto a noção de totem australiana quanto a noção de deus das religiões universais resultam, "en dernière analyse, en la notion du sacré" (MAUSS, 1904c, p. 203).

Feitas as considerações e críticas a respeito do objeto de estudo da disciplina, resta explicitar os pressupostos que a orientam, ou seja, em que consiste a metodologia da sociologia comparada das religiões. A primeira tarefa é a definição prévia ou inicial, que visa delimitar clara e distintamente os fenômenos a estudar, evitando confusões e equívocos. De acordo com o verbete "Sociologie" de Fauconnet e Mauss", as definições têm por objetivo a substituição das noções de senso comum, carregadas de preconceitos e ideologias, por noções científicas construídas racionalmente pelo pesquisador. Consideradas por Mauss como uma espécie de observação provisória, as definições designam "un ensemble de faits dont on prévoit la similarité fondamentale. Mais elles ne sont pas construites a priori, elles sont le résumé d'un premier travail, d'une première revue rapide des faits, dont on distingue les qualités communes" (FAUCONNET; MAUSS, 1901, p. 173). Dessa maneira, a definição científica acaba por unir aquilo que o senso comum separa e a distinguir o que o vulgo confunde. Apesar de a maior parte dos pesquisadores não se preocupar com nada além de reunir os fatos que comprovam sua teoria, a atenção com a integração de todos os fatos em uma definição que exprima os mesmos sinais exteriores tem o potencial de trazer à luz os elementos essenciais relativos a determinado fenômeno. Por conseguinte, é a definição inicial que torna possível o passo seguinte da observação metódica dos fatos. Segundo Fauconnet e Mauss, a observação científica não é e nem pode ser reduzida a um puro processo narrativo ou descritivo, pois não existem fatos brutos que possam ser registrados; isso porque os fenômenos sociais são demasiado complexos para serem apreendidos

9 O verbete foi assinado por Fauconnet e Mauss, mas Durkheim teve participação direta na redação de ao menos uma parte do trabalho (cf. DuRKHEIM, 1998, p. 257-261). Considerando o estilo de argumentação dos autores, podemos dizer que cada um dos autores ficou encarregado de redigir um dos três itens do verbete: o primeiro item, "Objet de la sociologie", foi escrito por Durkheim; o segundo, "Méthode de la sociologie", por Mauss; e o terceiro, "Divisions de la sociologie", por Fauconnet. 
diretamente. Ao contrário, a sociologia "doit faire plus que de décrire les faits, elle doit, en réalité, les constituer" (FAUCONNET; MAUSS, 1901, p. 173). Para tal empreendimento são necessários procedimentos analíticos específicos, que são designados por Mauss genericamente como métodos críticos. Seja para a análise de documentos estatísticos ou históricos, os métodos críticos visam sobretudo consolidar ou tornar confiáveis as informações obtidas por meio de uma crítica severa das fontes. Considerando a etnografia como parte do conjunto dos documentos históricos, Mauss advoga que a maneira de se certificar da veracidade das informações relatadas é, quando possível, contrastá-las com outras fontes disponíveis sobre o mesmo assunto, além de buscar conhecer o autor e, principalmente, as circunstâncias da observação ${ }^{10}$ (MAUSS, 1902a, p. 50). Para o autor, a análise sociológica difere daquela dos antropólogos e historiadores porque o objetivo não é o de investigar o detalhe singular de cada fato ou a sua datação específica, mas, antes, aquilo que é geral e característico entre os fatos observados. Dessa maneira, ao invés de investigar os fenômenos de superfície, expressões variáveis e singulares de eventos, cabe à sociologia "d'élever des substructures de faits solides et bien analysés" (MAUSS, 1902a, p. 50). Numa palavra, o sociólogo deve investigar os fatos profundos, que estão um passo além das informações dadas imediatamente na superfície da observação. Tratando especificamente dos fenômenos religiosos nas sociedades elementares, Mauss explicita a estratégia de combinar crítica e análise dos dados etnográficos da seguinte maneira:

Le "sauvage" est très souvent le dernier à savoir exactement ce qu'il pense et ce qu'il fait. Les meilleurs renseignements sont donc erronés si on les prend à la lettre. Il y a des difficultés constantes à atteindre les véritables faits. Cela provient de ce que les faits sociaux en général, les faits religieux en particulier, sont chose extérieure. Ils sont notre atmosphère intellectuelle, dans laquelle nous vivons ; et nous les pensons, comme quand nous nous servons d'une langue maternelle, sans volonté, et surtout sans conscience des causes mêmes de nos actes. De même que le linguiste doit retrouver sous les transcriptions fausses d'un alphabet les véritables phonèmes qui étaient prononcés, de même sous les renseignements les meilleurs des indigènes, Océaniens ou Américains, l'ethnographe doit retrouver les faits profonds, inconscients presque, parce qu'ils n'existent que dans la tradition collective. Ce sont ces faits réels, ces choses, que nous tâcherons d'atteindre à travers le document. Sachant que les rites et les croyances sont des faits sociaux,

10 Em um manuscrito de 1902 sobre a condução da pesquisa de campo durante a missão colonial francesa na Indochina, Mauss advoga que o etnógrafo deve se ater exclusivamente à tarefa da observação, esforçando-se para enunciar as condições de observação dos fatos descritos: "Le premier précepte c'est d'être précis. [...] Localiser un fait, c'est dire exactement toutes les circonstances où on l'a observé" (MAUSS, 2011, p. 154-155). 
difficiles à saisir, nous devrons toujours rechercher, messieurs, quel est leur véritable forme, leur mode d'existence, de transmission, de fonctionnement. Par ce côté, le travail de critique et le travail d'analyse coïncideront exactement (MAUSS, 1902a, p. 52-53; grifo nosso).

Comparando o trabalho do sociólogo ao do linguista, Mauss explica como um fenômeno religioso como um rito ou uma crença podem ser ao mesmo tempo exteriores e profundos: por estarem gravados na tradição coletiva, assim como a língua materna de um grupo, cabe ao pesquisador inferir o fenômeno real, ou seja, profundo e inconsciente, que corresponde ao signo enunciado por meio da atuação dos nativos. Por essa razão, mais do que os detalhes e especificidades temporais ou locais, o que importa na análise sociológica do fenômeno social é saber "ses antécédents, ses concomitants, ses conséquents, en un mot tout le cadre social qui l'entoure" (FAUCONNET; MAUSS, 1901, p. 174). Mais do que isso, um fenômeno social bem constituído e analisado em sua integridade perde justamente sua referência temporal, tal como um experimento conduzido em laboratório. Dessa maneira, o fenômeno social construído "devient un élément de science, et cesse d'appartenir en propre à tel ou tel pays, à telle ou telle époque. Il est pour ainsi dire placé, par la force de l'observation scientifique, hors du temps et hors de l'espace" (FAUCONNET; MAUSS, 1901, p. 174).

No entanto, a sociologia não limita seus procedimentos metodológicos à observação metódica dos fenômenos religiosos: ela ambiciona explicá-los. Para isso, é preciso sistematizá-los, ou seja, tornar inelegíveis suas relações com demais fenômenos sociais e organizá-los em um sistema racional. Apesar de a sociologia não poder recorrer às experimentações artificiais, como as feitas em laboratório, existiria um procedimento que, se conduzido dentro de determinados parâmetros, seria análogo à experimentação, qual seja, a comparação metódica:

L'expérimentation n'y est pas possible; on ne peut susciter, volontairement, des faits sociaux typiques que l'on pourrait ensuite étudier. Il faut donc recourir à la comparaison des divers faits sociaux d'une même catégorie dans diverses sociétés, afin de tâcher de dégager leur essence. Au fond, une comparaison bien conduite peut donner, en sociologie, des résultats équivalents à ceux d'une expérimentation. On procède à peu près comme les zoologistes, comme a procédé notamment Darwin. Celui-ci ne put pas, sauf pour une seule exception, faire de véritables expériences et créer des espèces variées; il dut faire un tableau général des faits qu'il connaissait concernant l'origine des espèces ; et c'est de la comparaison méthodique de ces faits qu'il dégagea ses hypothèses (FAUCONNET; MAUSs, 1901, p. 174; grifo nosso). 
Vista dessa maneira, a comparação metódica seria o equivalente da experimentação realizada em laboratório, ou seja, uma espécie de raciocínio experimental tal qual aquele utilizado por Darwin para determinar a origem e a evolução das espécies animais, mas que caberia também à investigação sociológica dos fenômenos religiosos: "Conditions nécessaires et universelles, faits primitifs, tout cela, nous croyons que la sociologie religieuse peut à découvrir, mais sans déplacer un fait de son cadre historique" (MAUSS, 1904b, p. 200). Dessa maneira, essa abordagem evolucionária em sociologia visa “s'assurer de la rationalité, de la nécessité, de la realité des séries logiquement constitués" (MAUSS, 1907b, p. 320). Ao vincularmos os fenômenos religiosos aos fenômenos sociais, ambos objetivamente observados, obteremos "ainsi des systèmes cohérents des faits, que nous pourrons exprimer en hypothèses, provisoires certes, mais en tous cas rationnelles et objectives" (MAUSS, 1902a, p. 53). Nesse quadro, as hipóteses científicas representam precisamente o elo entre as proposições teóricas mais gerais e os fenômenos sistematizados; na medida em que elas dizem o porquê e o como das coisas, as hipóteses constituem o meio para explicar os fenômenos sociais e religiosos. Conforme a conclusão de Mauss, é preciso renunciar tanto à tentação meramente descritiva e literal, quanto às teorias excessivamente gerais que apenas se servem dos fatos a título de ilustração, perseguindo as causas imediatamente determinantes dos fenômenos religiosos em outros fenômenos sociais.

\subsection{Da magia como fenômeno anômalo à origem mágico-religiosa do social}

$\mathrm{Na}$ referida conferência de abertura na EPHE, Mauss indicara que iniciaria suas atividades didáticas pelo estudo dos textos etnográficos sobre a magia entre os melanésios (MAUSS, 1902a, p. 51). Conforme atestam as resenhas e os artigos publicados nesse período, tanto Mauss quanto Hubert ${ }^{11}$ estavam engajados individual e conjuntamente em atividades de ensino e pesquisa relativas à magia. Nesse contexto, destacam-se dois trabalhos publicados em 1904: "L'origine des pouvoirs magiques dans les sociétés australiennes" de Mauss, baseado em um de seus cursos sobre os textos etnográficos australianos; e "Esquisse d'une théorie générale de la magie "12, outro fruto

11 Os trabalhos assinados somente por Hubert serão discutidos no capítulo seguinte.

12 As cartas de 1902 de Durkheim a Mauss já indicavam o projeto do artigo de 1904 (DURKHEIM, 1998, p. 311-312). Ademais, graças aos esforços de Jean-François Bert e Nicolas Meylan, a edição crítica do ensaio está disponível para consulta. Nela constam os manuscritos preliminares e as notas de rodapé suprimidas da versão original. Disponível em: < $\underline{\text { https://www2.unil.ch/hubert-mauss-magie/> } . ~}$ 
da colaboração entre Hubert e Mauss ${ }^{13}$. Ainda no preâmbulo do último ensaio, os autores justificam que o caminho que os levou do estudo do sacrifício ao da magia se deu, em parte, pela intenção de elaborar uma teoria geral dos ritos. Haveria um outro conjunto de ritos chamados mágicos que, à primeira vista, consistiriam em uma classe distinta fenômenos. Os fenômenos mágicos - que são praticados por indivíduos isolados do grupo que, por sua vez, além de estarem perseguindo interesses particulares, manipulam noções análogas à de sagrado - se apresentavam de tal maneira mal definidos e mal organizados que se torna impossível a tarefa de estabelecer seus limites, bem como a de indicar os fatos típicos de sua manifestação. Isso leva Hubert e Mauss à necessidade de estabelecer uma outra estratégia de investigação: não sendo possível observar um conjunto de fatos típicos para determinar seu mecanismo, como no caso do sacrifício, resta aos autores investigarem o meio próximo no qual os ritos mágicos ocorrem em suas diversas manifestações. A esse respeito, Frazer era o principal teórico do debate em torno dos fenômenos mágicos. Dito de maneira breve, o autor considerava que a magia poderia ser reduzida unicamente aos ritos simpáticos: ou seja, ritos que consistem em uma espécie de indução espontânea realizada pelos agentes mágicos, em que se admite que o semelhante age sobre o semelhante e o contrário age sobre o contrário. Há ainda, em Frazer, uma segunda hipótese mais geral: a de que a magia seria a forma primeira do pensamento humano, antecessora tanto da religião quanto das ciências. A magia sumarizaria, para Frazer, toda a vida mística e científica do primitivo. Todavia, ao contrário de Frazer, Hubert e Mauss não estavam convencidos de que a magia simpática seria o tipo puro de ato mágico, do qual todos os demais seriam derivados. Tal definição deixaria de lado, por exemplo, os encantamentos e os ritos em que intervêm entidades espirituais, qualificadas como mágicas. Dessa maneira, o defeito dessa e de outras abordagens residiria em sua parcialidade, de modo que não havia, portanto, uma noção clara, completa e satisfatória de magia, da qual um estudo científico pudesse partir. Foram consultados documentos etnográficos e históricos de sociedades que remetem às regiões de estudo de Hubert e Mauss, quais sejam, as australianas, melanésias, iroquesas, algonquinas, mexicanas, malaias, indianas, gregas,

13 Conforme atesta a edição crítica, a redação do artigo foi dividida entre Hubert e Mauss da seguinte maneira: a introdução foi redigida por Hubert; o capítulo 1 foi preponderantemente escrito por Hubert; o capítulo 2 foi preponderantemente escrito por Mauss; o capítulo 3 foi escrito tanto por Hubert quanto por Mauss e capítulo 4 e a conclusão foram preponderantemente redigidos por Mauss. 
latinas, francesas, germânicas, celtas e finlandesas. Mauss considera, por um lado, a província etnográfica australiana como um todo, pois havia uma abundância crescente de estudos cujos fatos eram particularmente homogêneos e comparáveis entre si; por outro lado, ele também nota a semelhança da classificação hindu acerca das diversas origens do poder mágico, que aplica-se quase que de maneira idêntica à da magia australiana: "On pourrait dire, avec les termes de Patañjali, qu'il provient de la naissance, de la connaissance des formules et des substances, de la révélation extatique" (MAUSS, 1904a, p. 10). Com efeito, esse insight sobre a quase perfeita semelhança dos fenômenos mágicos em tão distintos lugares e épocas já era objeto de reflexão de Mauss muito antes, ainda em 1898, em resenha para o primeiro volume do Année. Comentando um trabalho sobre as religiões populares e o folclore no norte da Índia, ele afirma que "[1]a sorcellerie est au fond la même chez les tribus aborigènes que chez les Hindous" (MAuss, 1898e, p. 215). Desde o princípio, Mauss compreendera a necessidade de tratar o maior número de manifestações mágicas heterogêneas para, assim, proceder à investigação de sua identidade comum.

Ao proceder dessa maneira, Hubert e Mauss observam, em primeiro lugar, que a magia está compreendida dentro do domínio da tradição: somente aquelas crenças e práticas que se repetem e que o grupo crê - ou ainda, que são eminentemente transmissíveis e sancionadas pela opinião pública - podem ser chamadas de mágicas excluindo, por conseguinte, as superstições particulares e individuais. As práticas tradicionais, por sua vez, compreendem desde atos jurídicos a técnicas e até ritos religiosos. Considerando que os atos jurídicos não produzem mais que convenções e não possuem nenhuma eficácia particular, cabe restringir a comparação entre ritos mágicos, técnicas e ritos religiosos. Apesar das últimas práticas serem consideradas criadoras, no sentido de que os gestos nelas executados são considerados igualmente eficazes, Hubert e Mauss sublinham a decisiva diferença: enquanto nas técnicas "l'effet est conçu comme produit mécaniquement", os ritos possuem "une efficacité toute spéciale, différente de leur efficacité mécanique" e são considerados, portanto, como “actes traditionnels d'une efficacité sui generis" (HuBERT; MAUSS, 1904, p. 15). Tomando os ritos mágicos como parte dos ritos religiosos, é preciso ainda buscar entre eles algum sinal de distinção mais evidente. Enquanto as religiões "se créent toujours une sorte d'idéal vers lequel montent les hymnes, les vœux, les sacrifices et que 
protègent les interdictions", a magia evita essas regiões e tende ao malefício; esses extremos formam, portanto, "les deux pôles de la magie et de la religion: pôle du sacrifice, pôle du maléfice" (HUBERT; MAUSS, 1904, p. 17). Em oposição à religião, os ritos mágicos agem de modo privado, muitas vezes isolados e cercados de mistério. Enquanto os sistemas organizados, como os cultos religiosos, são públicos e solenes, os ritos mágicos são considerados irregulares e anormais: numa palavra, no recurso ao feiticeiro ou ao mágico, há "nécessité et non pas obligation morale" (HUBERT; MAUSS, 1904, p. 19; grifo nosso). Conforme Mauss conclui em um resumo de curso sobre o mesmo problema, "la magie est un phénomène religieux, mais qu'elle se distingue de la religion proprement dite parce qu'elle est inorganique et n'est pas obligatoirement déterminée" (MAUSS, 1904d, p. 60). Esse caráter anômalo da magia, não só para o domínio religioso em si, mas para a própria sociologia durkheimiana - que estabelecia a obrigação como um elemento central da identificação de fenômenos sociais -, leva Hubert e Mauss a elaborarem a seguinte definição inicial: "Nous appelons ainsi tout rite qui ne fait pas partie d'un culte organisé, rite privé, secret, mystérieux et tendant comme limite vers le rite prohibé” (HUBERT; MAUSS, 1904, p. 19). Tal definição enfoca não a forma dos ritos mágicos, mas sua condição de existência dentro do conjunto mais amplo de práticas sociais.

O próximo passo, então, é o de caracterizar socialmente os elementos básicos envolvidos na magia, a saber: o mágico, os atos e as representações mágicas. Como regra, pode-se dizer que as práticas mágicas são sempre realizadas por especialistas - os mágicos - distinguidos dos demais agentes por qualidades adquiridas ou congênitas. $\mathrm{O}$ exercício da magia é dirigido àqueles que já possuem uma condição distinta no interior da sociedade da qual fazem parte: mulheres, forasteiros, deficientes e extáticos constituem exemplo dos tipos que predispõe a sociedade a crer que "ces états anormaux sont la manifestation d'une puissance inconnue qui rend la magie efficace" (HUBERT; MAUSS, 1904, p. 22). Por essa razão, o mágico possui uma situação socialmente definida como anormal. Um exemplo comum é o dos indivíduos considerados xamãs, que têm o poder de exalar sua alma - considerada seu duplo - e são, por isso, considerados mágicos. Esse procedimento implica em uma metamorfose do mágico, comumente associada à sua transformação em uma espécie animal. Para Hubert e Mauss, essas metamorfoses pelas quais passam xamãs e feiticeiros podem ser eventos 
sociologicamente interpretadas como estados de desdobramento da personalidade. Essa alteração da personalidade no plano individual significa o transporte para o mundo dos espíritos no plano social. Não obstante, são as condições exteriores definidas pela opinião pública que determinam quem são os indivíduos dotados de poderes mágicos (HuBERT; MAUSS, 1904, p. 36). Ainda assim, a mera classificação pela opinião pública não é suficiente para tornar-se mágico: é preciso passar por uma iniciação, realizada por revelação, consagração ou tradição. Nessas cerimônias de iniciação, por meio de uma série de ritos de ascetismo e tabus, o aspirante a mágico entra em contato com as forças ou espíritos que lhe conferem essa alteração permanente de personalidade. No ensaio sobre a origem dos poderes mágicos nas sociedades australianas, Mauss considera que todo o material etnográfico consultado aponta para espécies variantes de um mesmo tipo de conto de iniciação mágica por revelação, que, por sua vez, pode ser resumida em cinco teses (MAUSS, 1904a, p. 40-41): $1^{\text {a }}$ ) a iniciação é realizada por indivíduos em isolamento, não em grupo; $2^{\mathrm{a}}$ ) esses indivíduos possuem características congênitas ou adquiridas que os fazem crer serem aptos à magia, submetendo-se voluntariamente a severos tabus; $3^{\mathrm{a}}$ ) durante a cerimônia, experimentam necessariamente longos estados de êxtase; $4^{\mathrm{a}}$ ) o êxtase propicia um contato também prolongado com determinadas representações pessoais de espíritos ligados a fenômenos naturais, alterando profundamente a personalidade dos mágicos, que adquirem uma nova vida; $5^{\mathrm{a}}$ ) essa nova vida é resultado da absorção de uma substância mágica, geralmente representada por cristais de rocha que são introduzidos pelos espíritos nas entranhas do nativo durante o êxtase. Em alguns outros casos, uma confraria de mágicos assume o papel dos espíritos na comunicação das novas qualidades que conferem ao iniciado uma nova vida. Mas, independente de como a revelação é realizada, "ils ne dispensent pas de l'éducation par les anciens dans les secrets de l'art magique" (MAUSS, 1904a, p. 48). Como dizem Spencer e Gillen, demora um certo tempo para que o mágico arunta recém-iniciado se convença de que vivenciou as aventuras que a tradição lhe impôs por meio da revelação e do êxtase. É, enfim, necessário que "la révélation devient une espèce de tradition, même chez l'individu qui en fut le héros" (MAUSS, 1904a, p. 49). Tal processo de consolidação do poder adquirido pelo novo mágico é garantido por uma crença coletiva, partilhada tanto por ele quanto por seus adeptos, de sentimentos de temor e respeito por seu caráter extraordinário ou anormal. 
Em segundo lugar, temos os atos ou ritos mágicos, também caracterizados por certos traços típicos. Primeiro, há sempre uma observância com relação às condições e circunstâncias anormais no âmbito das quais os ritos devem ocorrer. Deve-se ter atenção ao local qualificado, à técnica empregada, aos utensílios e materiais necessários, ao dia e à hora específicos. Mesmo que se tratem de práticas banais, é preciso conferir a elas a qualidade de raras, extravagantes. Dessa maneira, depreende-se que "le rite magique se passe dans un milieu magique différencié, milieu que l'ensemble des préparations de la cérémonie a pour objet de limiter et de distinguer des autres milieux" (HUBERT; MAUSS, 1904, p. 46). Esses ritos podem ser manuais ou orais, positivos ou negativos; mas são sempre prescritos. Por essa razão, a preocupação do mágico é sempre menor em relação ao mecanismo do rito do que em relação à tradição que lhe transmite a prática ritual: ali tudo é determinado pela tradição, até mesmo o ritmo de execução das fórmulas e dos gestos mágicos. "En somme, les rites magiques sont extraordinairement formels et tendent, non pas à la simplicité du geste laïque, mais au raffinement le plus extrême de la préciosité mystique" (HUBERT; MAUSS, 1904, p. 56). Todo rito, enfim, é uma espécie de linguagem, um signo que traduz ou que exprime uma ideia.

Em terceiro lugar, temos as representações relativas ao domínio da magia. Uma vez que as práticas mágicas não são destituídas de sentido, o mínimo de representação que todo ato mágico comporta é aquele relativo a seu efeito. Nesse sentido, a magia implica uma confusão de imagens, em que "magicien, rite et effets du rite, donnent lieu à un mélange d'images indissociables" (HUBERT; MAUSS, 1904, p. 60). Confusão esta que é, ela própria, objeto de uma representação sintética, na qual se confundem as causas e os efeitos. "Entre le souhait et sa réalisation, il n'y a pas, en magie, d'intervalle" (HUBERT; MAuss, 1904, p. 61). Contrariamente ao que estipulava Frazer, Hubert e Mauss classificam as leis mágicas simpáticas apenas como um dos tipos de representações impessoais abstratas da magia, que podem ser discernidas em três variantes, a saber: as leis i) de contiguidade, nas quais a parte representa o todo; ii) de similaridade, nas quais o semelhante age sobre o semelhante; e iii) de contraste, nas quais o contrário age sobre o seu oposto; todas essas reconhecidas como formas de simbolização tradicional, em que "les liaisons fortuites des pensées équivalent aux liaisons causales des choses" (Hubert; Mauss, 1904, p. 62). Por essa razão, entende-se que essas leis mágicas 
representam propriedades que devem ser transmitidas de uma coisa para outra, limitando tanto a possibilidade de invenção quanto as regras de ação da magia. Tal limitação leva a crer que o pensamento mágico não pode viver apenas dessas abstrações que, do ponto de vista individual, não são senão raciocínios inconscientes. Dessa maneira, temos também que as representações mágicas visam propriedades eficazes, chamadas por Hubert e Mauss de representações impessoais concretas. À diferença das primeiras, para estas a noção de propriedade ou de poderes específicos das coisas mágicas desempenha um papel preponderante, aproximando ainda mais a magia da ciência: ao realizar um catálogo de plantas, minerais e animais, relacionando-os às suas propriedades especiais - experimentais ou não -, essas convenções sociais não fazem mais que estabelecer simpaticamente "véritables rudiments de lois scientifiques, c'est-àdire de rapports nécessaires et positifs que l'on croit exister entre des choses déterminées" (HuBERT; MAUSS, 1904, p. 75). Ora, tal operação de correspondência simbólica entre coisas e atributos consiste, precisamente, em operações de classificação: na magia, as coisas só podem agir umas sobre as outras "parce qu'elles sont rangées dans la même classe ou opposées dans le même genre", ou seja, porque a magia "agit avec des espèces classées" (HUBERT; MAUSS, [1904] 2003, p. 77). Já no artigo sobre as formas primitivas de classificação, Durkheim e Mauss (1903) ${ }^{14}$ trataram das classificações ligadas a sistemas mágicos e divinatórios que eram independentes da organização social - como os sistemas divinatórios chinês e grego. Em ambas as sociedades, a correspondência entre "certaines sortes d'événements et certaines planètes, la considération simultanée des espaces et des temps, la correspondance particulière de telle région avec tel moment de l'année, avec telle espèce d'entreprise, se rencontrent également"; nessas correspondências, cada elemento é relacionado a um ponto cardeal, a uma constelação, a uma cor determinada, e estes diversos grupos de coisas correspondem, por sua vez, "à diverses espèces d'organes, résidence des diverses âmes, aux passions et aux différentes parties dont la réunion forme 'le caractère naturel'" (DURKHEIM; MAUSS, 1903, p. 63). De acordo com os autores, na base do sistema de adivinhação existiria, portanto, um sistema de classificação, pois " $[\mathrm{t}]$ out rite

14 Estima-se que Durkheim tenha escrito a introdução e os itens I e V, enquanto Mauss redigiu as partes II, III e IV do artigo sobre as classificações primitivas. Conforme algumas cartas de 1902 indicam, Durkheim havia proposto a escrita desse artigo a Mauss, acompanhada de um plano de trabalho (cf. DURKHEIM, 1998, p. 318-320). 
divinatoire, si simple soit-il, repose sur une sympathie préalable entre certains êtres, sur une parenté traditionnellement admise entre tel signe et tel événement futur" (DuRKHEIM; MAUSS, 1903, p. 63). Mais do que meramente agrupar, os sistemas divinatórios coordenam esses grupos de sinais e eventos em um todo organizado, o que implica no reconhecimento de um sistema de classificação que lhe empresta sentido. Por fim, as representações pessoais são aquelas que associam a magia à ação de espíritos. Os Arunta australianos, por exemplo, possuem ao menos dois tipos de manifestações de espíritos mágicos, a saber: os orunchas e os iruntanias, considerados gênios locais. Segundo os autores, a noção de espírito mágico "substitue simplement l'idée d'une personne cause à l'idée de la causalité magique" (HUBERT; MAUSS, 1904, p. 78). Dessa maneira, conforme Mauss (1900d, p. 238) já havia notado em resenha acerca da magia entre os semitas, as noções de espírito e de demônio consistem, precisamente, em uma espécie de símbolo abstrato, personificado, do rito mágico.

Chega-se, então, a uma avaliação preliminar da análise dos elementos da magia. Os atos e as representações da magia "sont tellement inséparables qu'on pourrait fort bien l'appeler une idée pratique" (HuBERT; MAUSS, 1904, p. 90). Além disso, a análise de seus elementos constituintes mostra que esses diversos elementos da magia são criados e qualificados pela coletividade - e não podem, portanto, ser produto da experiência individual. A questão que se coloca, então, é de “[c]omment concevoir l'idée d'un phénomène collectif où les individus resteraient aussi parfaitement indépendants les uns des autres ?" (HUBERT; MAUSS, 1904, p. 88). Uma saída seria apostar na aproximação da magia à ciência. Afinal, também na ciência os princípios e os meios de ação são elaborados coletivamente e transmitidos por tradição, permitindo aos indivíduos relativa autonomia na prática científica. Essa hipótese é forte, e teria resolvido a questão, não fosse por um detalhe importante: quando da descrição dos elementos da magia, não foi possível constatar qualquer tipo de atividade criadora ou crítica dos indivíduos na prática mágica. Enquanto na ciência há algum tipo de acúmulo e desenvolvimento, vemos na atividade do mágico sempre a repetição das práticas prescritas pela tradição, o que indicaria ser o domínio religioso o espaço privilegiado dos fenômenos mágicos. A estratégia seguinte consiste, então, em buscar na magia forças coletivas semelhantes às que agem na religião, para daí demonstrar o caráter coletivo dos fenômenos mágicos em seu parentesco com os demais fenômenos religiosos. Procedendo à análise dessa ideia 
prática, Hubert e Mauss afirmam que a magia é, por definição, objeto de crença. A crença na magia pode ser considerada verdadeira na medida em que é a de todo o grupo: assim, a crença do mágico e a do público não são duas coisas diferentes; uma é o reflexo da outra, já que a atuação do mágico não é livre, e só é possível em razão da credulidade pública. À diferença das crenças científicas, as crenças mágicas são consideradas análogas às demais crenças religiosas porque também precedem, necessariamente, a experiência: em toda experimentação mágica, os fatos contraditórios são negados e somente as coincidências são tidas como fatos normais. "La magie est donc, dans son ensemble, l'objet d'une croyance a priori ; [...] c'est la nature de cette croyance qui fait que la magie peut aisément franchir le gouffre qui sépare ses données de ses conclusions" (HUBERT; MAUSS, 1904, p. 96). Não obstante, a eficácia dos ritos mágicos foi explicada, até então, pelas fórmulas simpáticas, pela noção de propriedade, ou mesmo pela noção de espíritos ou demônios. Como vimos, nenhuma dessas explicações ideológicas jamais foi suficiente para explicar as crenças nos atos mágicos, restando sempre um resíduo aos quais eles escapam. De acordo com Hubert e Mauss, tal resíduo consiste em duas noções, a saber: 1) de causa não-mecânica ou de força mágica, considerada a causa dos efeitos mágicos assim como a força mecânica é considerada a causa dos movimentos aparentes; 2) de um meio mágico em que os poderes são exercidos, meio este que guarda suas próprias regras de classificação que possibilitam as operações mágicas. Nesse sentido, ambas as noções de força e de meio mágicos são inseparáveis, pois "les formes rituelles, c'est-à-dire les dispositions qui ont pour objet de créer la force magique, sont aussi celles qui créent le milieu et le circonscrivent, avant, pendant et après la cérémonie" (HUBERT; MAUSS, 1904, p. 107). Ao apontar para as formas rituais como o locus de produção de força e meio mágicos, tal ideia composta escapa à psicologia individual intelectualista das tentativas de explicação anteriores. Ao contrário, explicar tal ideia composta engendrada pelos rituais demanda "une psychologie non intellectualiste de l'homme en collectivité" (HUBERT; MAUSS, 1904, p. 108).

Em princípio, a expressão que melhor condensa a ideia composta de força e meio mágicos seria a noção de mana, termo extraído da leitura de The Melanesians (1891), livro de Robert Codrington, etnógrafo missionário que trabalhou por anos entre os 
melanésios ${ }^{15}$. O termo em questão designa o poder mágico a partir de uma série de ideias amalgamadas umas nas outras: mana é considerado uma força, um ser, mas também uma ação, uma qualidade e um estado. Mana é palavra que é, ao mesmo tempo, substantivo, adjetivo e verbo, pois designa substância, qualidade e atividade. Tal noção, de difícil compreensão para a visão ocidental, teria ainda alguns outros correlatos, como arungquiltha arunta, mas também kramât malaio, deng b-nhar, hasina malaio-polinésio, manang dayak e orenda iroques. Pode-se dizer, então, que "le mana est la force par excellence, l'efficacité véritable des choses, qui corrobore leur action mécanique sans l'annihiler" (HUBERT; MAUSS, 1904, p. 111). O mana é dado a priori em relação a qualquer experiência e, antes de ser uma representação da magia, é ele também que rege as representações mágicas. Conforme os autores, se trata de uma categoria inconsciente do entendimento humano, ou, uma categoria do pensamento coletivo. Nesse sentido, o mana mantém uma relação de continuidade com a noção de sagrado: ambas são juízos de valor, estados afetivos da coletividade que atribuem certas propriedades a determinados elementos por meio de operações de classificação. No referido ensaio sobre as classificações primitivas, Durkheim e Mauss (1903, p. 70) concluíam que é “cette valeur émotionnelle des notions qui joue le rôle prépondérant dans la manière dont les idées se rapprochent ou se séparen" e, portanto, tais princípios religiosos como mana e sagrado servem "de caractère dominateur dans la classification". Entre os melanésios, existem relações entre as noções de mana e de tabu, mas de tal maneira que enquanto somente algumas coisas com mana eram tabu, todas as coisas tabu só o eram por possuírem mana. Por essa razão, os autores concluem que "le sacré est une espèce dont le mana est le genre" (HUBERT; MAUSS, 1904, p. 120).

No entanto, apesar da noção de mana dar a coesão e a coerência que o fenômeno mágico não apresentava, ela ainda aparece como que independente dos mecanismos sociais. É preciso, então, remontar às forças coletivas das quais a magia é produto e a noção de mana a expressão. Admitindo a impossibilidade de indivíduos sozinhos operarem juízos mágicos estabelecidos pela tradição que os antecede, Hubert e Mauss constatam que haveria sempre, no mínimo, dois indivíduos, o mágico que cumpre o rito e aquele que acredita em sua eficácia. Conforme observa a dupla de autores, esse par teórico irredutível forma uma sociedade e constitui, portanto, a base lógica da sintese

15 Para uma história intelectual da noção de mana no debate acadêmico desde Codrington, cf. Meylan (2017). 
coletiva operada nos mais diferentes níveis e grupos. Os juízos mágicos nada mais são que convenções, à maneira de associações gerais e apriorísticas, que lhes imprimem sua origem coletiva: “C'est parce que l'effet désiré par tous est constaté par tous que le moyen est reconnu apte à produire l'effet ; [...] La synthèse de la cause et de l'effet ne se produit que dans l'opinion publique" (HUBERT; MAUSS, 1904, p. 126-127). Se para a magia existir é necessária a presença da sociedade, é preciso prescrutar como a sociedade se faz presente e age para produção desses fenômenos. Sendo a magia baseada em ideias comuns mas em ritos facultativos, o primeiro obstáculo refere-se à própria premissa durkheimiana de que "les contraintes et les prohibitions sont la marque significative de l'action directe de la société" (HuBERT; MAUSS, 1904, p. 128). Diferentemente daquela adotada por Durkheim, a estratégia de Hubert e Mauss para sublinhar o substrato social dos fenômenos mágicos é de observar como estes últimos partilham certas homologias com os demais fenômenos religiosos. Em relação aos ritos negativos, cumpre notar que, assim como no sacrifício, a magia demanda e produz uma alteração de espírito nos envolvidos por meio de uma gama de técnicas que descrevemos; tomados em conjunto, podemos dizer que os ritos negativos na magia formam um limiar a partir do qual o indivíduo abdica de si para performar ali apenas o personagem do rito, para assumir um papel social. Nesse sentido, à maneira da religião, a magia também possui seu próprio sistema de interdições rituais, que não é senão parte do sistema mais geral de interdições coletivas e concorre, por assim dizer, com o da religião. Essas observâncias negativas, por sua vez, não afetam somente os diretamente envolvidos na prática da magia, mas todos aqueles que partilham da opinião pública e que estão como espectadores absorvidos pelo drama mágico. Nesse sentido, a coletividade igualmente impõe determinados estados afetivos que estão na raiz das práticas mágicas, tais como possessões e excitabilidade; mais especificamente, esses estados provém e são transmitidos pelos estados de êxtase coletivo que acontecem entre indivíduos associados em certas práticas rituais. Nas sociedades malaio-polinésias, por exemplo, esses ritos negativos são seguidos por ritos públicos positivos, em que o grupo persegue em conjunto uma meta única preconcebida, muitas delas sem a figura do mágico, mas que possuem uma tonalidade religiosa - apesar da religião mesma ou do culto organizado ainda não terem emergido. Citando o exemplo dos povos Dayak, Hubert e Mauss contam que as mulheres manejam sabres como se estivessem elas 
mesmas guerreando para que os homens tenham êxito durante a guerra, além de seguir uma série de interdições para performar os hábitos dos guerreiros, como levantar cedo etc; ou seja, do sucesso do rito mágico público depende o sucesso da guerra. Há, além deste, outros exemplos, como o dos indígenas australianos que se engajam na cerimônia da chuva; os ritos mágicos positivos são um dos extraordinários momentos nos quais seria possível observar com clareza como as formas rituais elementares constituem a gênese de fenômenos coletivos. Por meio da análise dos processos envolvidos no rito mágico público relatado abaixo, teríamos acesso a um desses momentos na vida das sociedades nos quais se fabrica conscientemente o social:

Tout le corps social est animé d'un même mouvement. Il n'y a plus d'individus. Ils sont, pour ainsi dire, les pièces d'une machine ou, mieux encore, les rayons d'une roue, dont la ronde magique, dansante et chantante, serait l'image idéale [...] Ce mouvement rythmique, uniforme et continu, est l'expression immédiate d'un état mental où la conscience de chacun est accaparée par un seul sentiment, une seule idée, hallucinante, celle du but commun. Tous les corps ont le même branle, tous les visages ont le même masque, toutes les voix ont le même cri ; sans compter la profondeur de l'impression produite par la cadence, la musique et le chant. A voir sur toutes les figures l'image de son désir, à entendre dans toutes les bouches la preuve de sa certitude, chacun se sent emporté, sans résistance possible, dans la conviction de tous. Confondus dans le transport de leur danse, dans la fièvre de leur agitation, ils ne forment plus qu'un seul corps et qu'une seule âme. C'est alors seulement que le corps social est véritablement réalisé. Car, à ce moment, ses cellules, les individus, sont aussi peu isolées peut-être que celles de l'organisme individuel. Dans de pareilles conditions (qui, dans nos sociétés, ne sont plus réalisées, même par nos foules les plus surexcitées, mais que l'on constate encore ailleurs), le consentement universel peut créer des réalités. [...] Les lois de la psychologie collective violent ici les lois de la psychologie individuelle. Toute la série des phénomènes, normalement successifs, volition, idée, mouvement musculaire, satisfaction du désir, deviennent alors absolument simultanés. C'est parce que la société gesticule que la croyance magique s'impose et c'est à cause de la croyance magique que la société gesticule (HUBERT; MAUSS, 1904, p. 134-135; grifo nosso).

A passagem citada mobiliza um conjunto de metáforas no intuito de precisar como esses rituais públicos mágico-religiosos encontrados nas sociedades elementares agenciam uma variedade de procedimentos que, ao serem realizados de uma determinada maneira em determinada condição, criam novas realidades para aqueles engajados na realização do drama. A esse respeito, a imagem da ciranda tem por objetivo oferecer uma unidade mais ou menos coerente para esse processo de dramatização ritual: uma certa dança 
dramática que denota a agitação repetida, ritmada e sincrônica de gestos, vozes e sons, produzindo uma um meio social especial, diferente e separado da vida ordinária, em que ocorre uma espécie de unidade ou alinhamento alucinante de todos os participantes em torno de uma certa ideia, também comum, como a de mana. Em uma resenha do ano anterior, Mauss (1903b) já havia salientado o fenômeno do ritmo como constituinte dos rituais religiosos elementares, uma vez que essas cerimônias se baseiam, sobretudo, em danças e cantos realizados coordenada e conjuntamente pelo grupo:

Le "chant en commun", le choral, voilà la cause du rythme. [...] Le choral primitif suppose, non seulement un groupe d'hommes, mais encore un groupe d'hommes qui concertent leurs voix ainsi que leurs gestes, qui forment une même masse (throng) dansante. La communauté animée des mouvements rythmiques, voilà la condition immédiate, nécessaire et suffisante de l'expression rythmique des sentiments de cette communauté. [...] - Ainsi derrière le simple fait du rythme apparaît une réalité sociale, un groupe déterminé d'individus chantant et dansant. Le rythme, faculté d'ensemble, vient directement d'une action faite d'ensemble (MAUSs, 1903b, p. 561-562; grifo nosso).

Conforme Mauss, o ritmo é produto do concerto de vozes e gestos que formam a imagem da multidão cantando e dançando em conjunto. Ao mesmo tempo, esse movimento rítmico realizado pelo grupo é a expressão simbólica dos sentimentos sociais comuns a todos os engajados no drama ritual, interpretado, então, como a sociedade gesticulando suas crenças, performando dramaticamente em uníssono suas ideias recém-produzidas ou reafirmadas a partir desses mesmos gestos ${ }^{16}$. Por essa razão, o ritmo é qualificado por Mauss como uma faculdade de associação entre pessoas que realizam diferentes esforços simultaneamente: "le langage devient naturellement rythmé parce que le rythme est le seul moyen d'établir un concert juste des différents efforts vocaux. Et aussi le rythme est bien le résultat de l'association" (MAUSS, 1903b, p. 563; grifo nosso). Portanto, o ritmo é um símbolo da associação produzida pelos atos e pensamentos realizados ritualmente e expressa, por essa razão, os sentimentos sociais da ação coletiva. Dito em outros termos, o drama ritual performado pelos membros em conjunto constitui o processo responsável por produzir aqueles estados de êxtase coletivo, marca sui generis dos fenômenos religiosos elementares, que, ao ocorrerem, abrem a possibilidade para a criação de novas realidades, isto é, novos ideais que

16 Em manuscrito preparatório ao ensaio sobre a magia, Mauss afirma que são essas as cerimônias nas quais produz-se solidariedade mecânica (cf. MAUSS, 2015, p. 290). 
orientem as ações e os pensamentos dos indivíduos associados. Estamos diante, portanto, de eventos que constituem a gênese tanto da magia quanto da religião, fatos esses "qui perpétuent ceux où a dû se former la notion de mana" (HuBERT; MAUSS, 1904, p. 137). É por essa razão que tais eventos limite, ao constituírem um consentimento universal dos membros do grupo em torno de determinada meta ou ideal comum, não fazem senão fabricar conscientemente o social - aquilo que na vida ordinária e individual acontece quase sempre de modo inconsciente.

Dessa maneira, os ritos públicos mágico-religiosos servem para indicar a matriz dos elementos sociais que qualquer cerimônia mágica reproduz continuamente, ainda que de maneira atenuada. Se é impossível conceber o mágico sem o meio social que o produz, agora temos melhores condições de compreender como os grupos mágicos decompuseram-se em indivíduos e, paralelamente, as necessidades coletivas públicas dos grupos elementares deram lugar a necessidades individuais. Conforme ponderam os autores: "sur ce fond de phénomènes sociaux, il est très remarquable que, dès que la magie s'est différenciée de la religion, il ne se détache plus que des phénomènes individuels" (HuBERT; MAUSS, 1904, p. 141). Conforme verificado por Mauss, esse é o caso das sociedades australianas, nas quais o mágico é alguém que é considerado por si e pelos outros como singular: confundindo-se com o espírito que o inicia por meio da posse de determinada substância mágica, o indivíduo que se torna mágico tem toda sua personalidade renovada durante os períodos de êxtase experimentados na cerimônia de iniciação. Essa alma nova adquirida na iniciação é seu mana, o poder mágico que o habilita à profissão mágica. Conforme conclui Mauss, o mágico australiano "est un être que la société détermine et pousse à remplir son personnage" (MAUSS, 1904a, p. 55). Nesse sentido, foi pela educação e pela tradição que a magia pode sobreviver como fenômeno individual. Assim como para a transmissão do conhecimento científico e das técnicas, também na magia são os processos de socialização que tornam os indivíduos aptos a apreender a tradição e a desenvolvê-la. Também por essa razão, cada vez mais a magia assemelhou-se progressivamente à ciência e à técnica: "Elle tâche de ne garder de collectif que son caractère traditionnel ; tout ce qu'elle fait de travail théorique et pratique est l'œuvre d'individus ; elle n'est plus exploitée que par des individus" (Hubert; MAuss, 1904, p. 142). A magia é, portanto, um fenômeno religioso que mantém um parentesco verdadeiro com as técnicas e com a ciência. Por um lado, tanto a 
magia quanto as técnicas possuem a mesma função: ao contrário da religião, que tende ao abstrato, a magia tende ao concreto e, assim como as técnicas, está diretamente ligada à prática. Do mesmo modo, a magia liga-se à ciência por sua capacidade de classificar hierarquicamente o conhecimento obtido, bem como de investigar seus princípios: foram os feiticeiros os primeiros a refletir e fazer observações sobre a natureza, bem como a sistematizar um método de educação intelectual individual. Consequentemente, ao analisar a origem religiosa da magia, Hubert e Mauss constatam que ela constitui "la forme première de représentations collectives qui sont devenues depuis les fondements de l'entendement individuel", demonstrando "comment un phénomène collectif peut revêtir des formes individuelles" (HUBERT; MAUSS, 1904, p. 146). Após uma origem comum, religião e magia opuseram-se no interior do mesmo domínio religioso: sacerdotes e deuses de um lado, feiticeiros e demônios de outro (MAUSS, 1900e, p. 240).

\subsection{Relações entre morfologia e fisiologia: os períodos de efervescência coletiva}

Paralelamente à realização dos trabalhos sobre a magia e das análises sobre as sociedades australianas e melanésias, Mauss adquire um crescente interesse no estudo comparado das etnografias dos povos indígenas que se estendem do continente norteamericano ao círculo polar ártico. Assim como no que diz respeito à Austrália, diversos trabalhos etnográficos foram realizados acerca dos povos da América do Norte. O período entre 1903 e 1906 compreende uma série de cursos dedicados à etnologia dos esquimós $^{17}$ (1903-1904 e 1904-1905), bem como das demais sociedades indígenas do noroeste do continente norte-americano (1905-1906), além de uma série de resenhas para o Année. Ao analisar os fatos etnográficos norte-americanos, principalmente a partir dos trabalhos de Franz Boas, em 1903 Mauss já havia observado que eles direcionavam quase todas as questões relativas aos ritos e ao mitos às chamadas danças de inverno ${ }^{18}$, "ce tissu étrangement compliqué de cérémonies divisées à l'excès entre des confréries et à l'intérieur de ces confréries" (MAUSS, 1903c, p. 248). Assim como para os povos australianos, também entre as tribos norte-americanas o sistema

17 O termo abrange um conjunto de nações indígenas do círculo polar ártico, como os Aleut, Inuit e Yupik.

18 Essas cerimônias de inverno foram posteriormente denominadas potlatch, e Mauss já planejava escrever algum trabalho mais extenso sobre o fenômeno no futuro (cf. MAUSS, 1910a, p. 115). 
mitológico relacionava-se diretamente a essas cerimônias públicas, nas quais os mitos eram representados por meio de máscaras, pinturas, danças e preces; ou seja, também para as sociedades norte-americanas a representação figurada dos mitos durante os rituais mágico-religiosos era tanto um meio de consagração quanto de transcrição dos diversos mitos (MAUSS, 1903c, p. 250-251). Reconhecendo a religiosidade impregnada nas representações coletivas da maior parte dessas sociedades, Mauss concentrou-se, nesse conjunto de trabalhos, na análise "des relations générales d'un groupe et de son milieu avec sa mentalité” (MAUSS, 1903d, p. 225). Dessa maneira, Mauss retoma uma parte importante dos preceitos previamente desenvolvidos por Durkheim, a saber, a relação entre os fatos de morfologia e de fisiologia social e, mais especificamente, sobre o papel dos fenômenos morfológicos nas explicações sociológicas. Nesse sentido, o artigo escrito em colaboração por Durkheim e Mauss (1903) constitui uma primeira tentativa de enquadrar o problema da relação entre morfologia e representações a partir das formas de classificação das sociedades elementares. Um dos sistemas analisado em pormenor foi aquele dos Zuñis, povo americano cujo sistema de classificação consistia na divisão do espaço em sete regiões, na qual a cada região é atribuído um conjunto de elementos tais como cor, estação do ano, eventos naturais, plantas, animais. E, o que é mais importante, "cette répartition des mondes est exactement la même que celle des clans à l'intérieur du pueblo" (DURKHEIM; MAUSS, 1903, p. 36), que são também divididos em sete partes e sinalizam, portanto, uma relação entre a repartição do espaço e a repartição dos clãs. Para uma boa parte das sociedades norte-americanas, australianas e melanésias, haveria uma noção de orientação mítica relativa a cada clã: isto poque assim como "la tribu constitue pour le primitif toute l'humanité, de même que l'ancêtre fondateur de la tribu est le père et le créateur des hommes, de même aussi l'idée du camp se confond avec l'idée du monde", fazendo da tribo ou do grupo local uma espécie de microcosmo do universo (DURKHEIM; MAUSS, 1903, p. 54).

Essa maneira dos clãs americanos imprimirem sua forma no ambiente que os circunda foi precisamente o que chamou a atenção de Mauss durante o período, o que culminou na publicação, em 1906, do "Essai sur les variations saisonnières des sociétés eskimos", escrito em colaboração com Henri Beuchat ${ }^{19}$. Como o próprio título sugere,

19 Estima-se que, por uma série de dificuldades, Beuchat tenha contribuído apenas para a redação e elaboração das figuras da subseção "II. Morfologia sazonal" (cf. FoURNIER, 1994, p. 301-302; DURKHEIM, 1998, p. 365-368). Aluno de Mauss na EPHE e autodidata, considerado um dos primeiros 
trata-se de um estudo de morfologia social, ou seja, das formas a partir das quais as sociedades se estabelecem e se distribuem no território, bem como das mudanças de volume e densidade da população dessas sociedades. A escolha das sociedades esquimó consiste em estratégia metodológica para demonstrar uma lei da vida coletiva que, ao menos entre os Esquimó, seria marcadamente visível, a saber: a forma e a natureza das instituições esquimó variam com uma amplitude excepcional conforme as estações do ano, o que permitiria investigar uma dinâmica mais geral da vida coletiva que, apesar de existente, não se faz possível observar com tanta acuidade em outras sociedades. Considerando a enorme extensão e a pequena densidade da população Esquimó, dada por uma série de fatores impostos pelo próprio grupo e pelas condições do ambiente que ocupa, Mauss e Beuchat interessaram-se sobretudo pelas variações que ocorrem no modo de vida esquimó de acordo com as duas estações do ano no local: no verão, os membros do assentamento habitam em tendas dispersas, ao passo que, no inverno, habitam em casas bem próximas umas das outras. Dessa maneira, durante o verão, em que a oferta de caça e pesca é mais abundante e as migrações são frequentes, cada família vive distante uma da outra em habitações móveis, as tendas, ocupadas apenas pelo núcleo familiar restrito - casal e filhos; já durante o inverno, que restringe drasticamente a oferta de alimentos, as famílias, que praticamente não se deslocam nesse período, vivem em conjunto, aglomeradas em casas coletivas. Do ponto de vista da organização social e jurídica, cada tipo de organização doméstica corresponde a um tipo de direito familiar: enquanto na família de verão o direito é patriarcal, isto é, centrado na figura do pai ou filhos em idade de caçar, na família de inverno o direito é comunal, pois cada família nuclear dissolve-se para formar uma grande joint-family, assemelhando-se a um clã. Um exemplo desse traço comunal do direito e do parentesco no inverso é o costume da troca de mulheres, comum a todas as sociedades esquimó e praticada especialmente durante as festas coletivas de inverno. A mesma lógica se aplica ao direito de propriedade: se no verão os objetos pertencem aos indivíduos ou ao grupo familiar restrito, no inverno esse direito cede espaço a uma espécie de regime comunitário ou coletivista de uso dos bens, no qual tudo que é consumido é partilhado igualmente entre todos, principalmente nos momentos de escassez. Assim como o potlatch dos indígenas vizinhos, os Esquimós mantêm uma instituição análoga, firmada 
por meio “d'un contrat réel, personnel, général, obligeant l'acheteur à échanger tout ce qu'il possède avec le vendeur", ao passo que o vendedor, por sua vez, realiza um rito que o faz "retient toujours une parcelle (d'âme?) de la chose vendue" (MAUSS, 1904e, p. 228). Ora, esse “communisme économique de l'hiver est remarquablement parallèle au communisme sexuel de la même saison et montre, une fois de plus, à quel degré d'unité morale parvient, à ce moment, la communauté eskimo" (MAUSS; BEUCHAT, 1906, p. 121). Ao observar a alternância do modo de organização social que compreende uma série de grupos esquimó, os autores depreendem que ela "exprime le rythme de concentration et de dispersion par lequel passe cette organisation morphologique" e, portanto, que o "mouvement dont est animée la société est synchronique à ceux de la vie ambiante" (MAUSS; BEUCHAT, 1906, p. 94-95). Trata-se de uma dinâmica social que, apesar de sincronizar-se com o ambiente, não é causada por fatores naturais ou técnicos. Conforme Mauss já havia observado em outros trabalhos, tanto a dupla morfologia quanto as classificações baseadas em características do ambiente são partilhadas por uma série de outras sociedades norte-americanas.

Assim como acontece com os demais elementos da organização social esquimó, a religião submete-se ao mesmo ritmo, alternando de padrão cerimonial entre o inverno e o verão. Tal alternância entre padrões é observada, inclusive, em outros povos vizinhos, como os Statlumh e os Kwakiutl, que também são sociedades de dupla morfologia, organizando tanto casas coletivas quanto festas sazonais de inverno (MAUSS, 1907, p. 236-237); o mesmo vale para os Koryak do estreito de Bering, cujo inverno é também a estação religiosa por excelência (MAUSS, 1910b, p. 149). Mas há também outros povos norte-americanos de outras regiões que, guardadas as diferenças, também mantêm uma orientação sazonal de acordo com as estações do ano, como os Hopi, que realizam dramas rituais solares durante o verão (MAUSS, 1904f, p. 287); da mesma maneira, os Kiowa possuem um drama solar anual, também conhecido como a dança solar, na qual os membros figuram o sol, o búfalo e o peiote como parte de um mesmo tipo de classificação (MAUSS, 1904g, p. 284); há, ainda, os Zuñi, cujo elemento central ritualístico consiste em uma série de "répresentations dramatiques où sont figurés la marche des dieux, leur arrivée à Zuñi, celle du soleil qui vient faire le feu du nouvel an" (MAUSS, 1910c, p. 132). Já para os Esquimó, enquanto no verão a vida é "comme laïcisée" e as cerimônias religiosas são praticamente inexistentes, ocorrendo 
ocasionalmente apenas cultos domésticos privados de nascimento e de morte, no inverno, ao contrário, a exaltação religiosa é contínua, e pode-se mesmo conceber "toute la vie de l'hiver comme une sorte de longue fête" (MAUSs; BEUCHAT, 1906, p. 97). O período invernal é marcado, com efeito, por uma ampliação do sistema de interdições, pela realização de sessões públicas de xamanismo contra a escassez de alimentos, e até pelas famosas danças perpétuas de inverno. Tudo isso marca o caráter sagrado que caracteriza a vida esquimó no inverno. A esse respeito, nas ocasiões celebradas pelos Unalit do Alasca ocorrem "nombreuses danses avec masques en présence de toute la communauté qui chante" e lança as bexigas de todos os animais marinhos mortos ao longo do ano para, assim, assegurar a subsistência para o ano seguinte (MAUSS; BEUCHAT, 1906, p. 99). Da mesma maneira, as festas do solstício de inverno consistem em apagar e reacender simultaneamente todas as lâmpadas da casa coletiva, produzindo uma espécie de culto do fogo coletivo. O exemplo mais completo é fornecido por outra festa também observada ente os Unalit, a festa dos mortos, que parece ser praticada em toda a extensão do território esquimó:

Elle comprend deux parties essentielles. On commence par prier les âmes des morts de bien vouloir se réincarner momentanément dans les homonymes que chaque mort a dans chaque station ; car c'est un usage que le dernier né porte toujours le nom du dernier mort. Ensuite, on charge de présents ces homonymes vivants qui représentent les morts ; on échange des cadeaux dans tout l'assemblée et on congédie les âmes qui quittent leurs habitats humains pour retourner au pays des morts. Ainsi, à ce moment, non seulement le groupe retrouve son unité, mais voit se reformer dans un même rite le groupe idéal composé de toutes les générations qui se sont succédé depuis les temps les plus reculés. Les ancêtres mythiques et historiques aussi bien que récents viennent se mêler aux vivants et tous communient ensemble par des échanges de cadeaux (MAUSS; BEUCHAT, 1906, p. 99-100; grifo nosso).

Temos na descrição das festas de inverno esquimó uma série de elementos já presentes em outras análises que agregam-se, então, a novos fatos. Há, em primeiro lugar, certas semelhanças entre os ritos de reprodução animal ou planta totêmica e o rito das bexigas: ambos visam garantir a reprodução das espécies em questão; também é o caso da relação entre os nomes dos antepassados, que são adquiridos pelos vivos por meio de cerimônias específicas para essa transmissão. Em uma resenha anterior, Mauss comentava a celebração dessas festas, relacionando-as com a controversa discussão sobre a existência de cultos totêmicos entre os esquimó: conforme observara, durante os 
dramas os nativos representavam espécies totêmicas por meio das máscaras, bem como realizavam danças contínuas para estabelecer contato com seus ancestrais (MAUSS, 1904e, p. 225-227). Mas há, também, outra observação mais geral sobre as cerimônias das sociedades elementares de que os esquimós também fazem parte, a saber: a produção da consciência do grupo por meio dos rituais religiosos, que exprimem dramaticamente a unidade coletiva do grupo enquanto tal e, consequentemente, produzem "le sentiment que la communauté a d'elle-même, de son unité", uma vez que tais festas "sont la chose du groupe et c'est le groupe qu'elles expriment" (MAUSS; BEUCHAT, 1906, p. 98). Ainda há outras particularidades nessas festas de inverno esquimó: o já observado comunismo sexual, considerado parte dessa forma de comunhão característica a todos os grupos no inverno, bem como o rito de troca de presentes ou dádiva entre todos os membros do grupo presentes, dos antepassados míticos aos vivos. Todos esses não são senão os meios rituais pelos quais os esquimós performam dramaticamente a consciência de sua unidade coletiva.

Por conseguinte, essa oposição entre a vida no verão e no inverno incide também sobre as representações coletivas dos esquimós. Por exemplo, os Oqiomiut e os Nugumiut praticam um conjunto de festas cujos membros são divididos entre os nascidos no verão e os no inverno para disputar uma espécie de cabo de guerra, que os nascidos no verão, os aggim, posicionam-se no lado da terra, ao passo que os nascidos no inverno, os axigïrn, posicionam-se no lado da água. Já entre os Angmagssalik, quando a criança nasce no verão sua primeira refeição é um caldo à base de algum animal terrestre ou de rio cozido em água doce; se nascer no inverno, sua primeira refeição será um caldo de animal marinho cozido em água do mar. Nesse sentido, a essa divisão das pessoas em duas grandes categorias liga-se uma outra divisão, ainda mais geral, que compreende todas as coisas, divididas entre coisas de verão e de inverno por meio de uma série de interdições rituais. A esse respeito, o contato entre peles de animais de verão, como a rena ou o salmão, e animais de inverno, como a morsa, é proibido, estendendo a interdição aos artefatos e às roupas usadas para caçar cada um deles; ao fim do verão, as tendas das famílias devem ser enterradas embaixo de pedras, pois no inverno tornam-se shongegew. Com efeito, a não observância dessas interdições imprime uma mancha em quem a cometer; essa mancha é transmitida por contágio a todos ao redor, o que espanta a caça e instaura a escassez de alimentos para o grupo. Os 
esquimós, portanto, classificam as pessoas e as coisas a partir da oposição cardinal entre as duas estações, de modo que "la notion de l'hiver et la notion de l'été sont comme deux pôles autour desquels gravite le système d'idées des Eskimos" (MAUSS; BEUCHAT, 1906, p. 103). Ora, aqui voltamos ao sistema morfológico que é constituinte não só da civilização esquimó, mas dos povos da América do Norte como um todo. Desde o artigo sobre as classificações primitivas, havia a noção de um padrão de classificação bipartido dessas sociedades elementares norte-americanas elaborado a partir dos aspectos mais relevantes de seu ambiente: os Zuñi repartiam o espaço de acordo com a repartição dos clãs e, a partir desta, orientavam a repartição de conjunto de elementos tais como cor, estação do ano, eventos naturais, plantas, animais; os Tlinkit, por exemplo, figuravam diversos seres míticos em tatuagens de montanhas, árvores, pedras e animais que eram repartidos entre duas fratrias, remontando à mesma lógica de classificação totêmica bipartida (MAUSS, 1910a, p. 118-119); entre os Koryak, por sua vez, "l'opposition de l'hiver et de l'été semble affecter la représentation du monde spatial" (MAUSS, 1910b, p. 149) cria uma classificação também baseada nas estações do ano.

De todo o exposto, pode-se depreender que a vida social esquimó apresenta-se sob duas formas paralelas a uma dupla morfologia: por um lado, uma comunhão e forte unidade moral e religiosa durante a densa aglomeração do inverno, seguida de dispersão e isolamento no verão, produzindo uma vida moral e religiosamente pobre. Conforme concluem os autores, essa alternância entre dois períodos de intensidade desigual da vida coletiva estabelece, portanto, um ritmo regular na vida social esquimó:

L'hiver est une saison où la société, fortement concentrée est dans un état chronique d'effervescence et de suractivité. Parce que les individus sont plus étroitement rapprochés les uns des autres, les actions et les réactions sociales sont plus nombreuses, plus suivies, plus continues ; les idées s'échangent, les sentiments se renforcent et s'avivent mutuellement ; le groupe, toujours en acte, toujours présent aux yeux de tous, a davantage le sentiment de lui-même et tient aussi une plus grande place dans la conscience des individus. Inversement, en été, les liens sociaux se relâchent, les relations se font plus rares, les individus entre lesquels elles se nouent sont moins nombreux ; la vie psychique se ralentit. Il y a, en somme, entre ces deux moments de l'année toute la différence qu'il peut y avoir entre une période de socialité intense, et une phase de socialité languissante et déprimée. Voilà qui achève de prouver que la longue maison d'hiver ne s'explique pas uniquement par des raisons techniques. C'est évidemment un des éléments essentiels de la civilisation eskimo qui apparait quand cette civilisation atteint son maximum de développement, se réalise aussi intégralement que possible, qui 
disparait quand elle s'affaiblit et qui, par conséquent, est fonction de toute cette civilisation (MAUSS; BEUCHAT, 1906, p. 125; grifo nosso).

O trecho acima compreende a primeira parte da explicação das variações sazonais esquimó. Ao identificar o padrão de alternância da vida social esquimó, os autores tratam de eliminar qualquer possibilidade de explicação atribuída a questões biológicas, ambientais ou técnicas, afirmando que a tal mudança de organização da vida se deve a elementos essenciais de sua civilização; ou seja, é antes porque o grau de socialidade varia que tanto a morfologia quanto a fisiologia social dos esquimós também varia. Para comprovar essa tese, os autores lembram, noutra passagem, que os esquimós do estreito de Bering e da ponta Barrow já tiveram que se aproximar durante o verão por situações excepcionais e retomaram as casas coletivas e, com isso, as festas, danças e trocas públicas que usualmente ocorrem durante o inverno; ou seja, as estações do ano não são a causa determinante e apenas agem em conformidade às regras da civilização esquimó. Tal procedimento baseia-se, primariamente, na densidade dinâmica - isto é, para determinado volume, o número de pessoas que estão efetivamente em relações morais e vivem uma vida comum -, o elemento da morfologia capaz de transformar o curso dos fenômenos sociais. Com efeito, o melhor índice da densidade moral de um grupo é, segundo Durkheim, o grau de coalescência dos segmentos sociais, que estabelece a seguinte razão:

si chaque agrégat partiel forme un tout, une individualité distincte, séparée des autres par une barrière, c'est que l'action de ses membres, en général, y reste localisée ; si, au contraire, ces sociétés partielles sont toutes confondues au sein de la société totale ou tendent à s'y confondre, c'est que, dans la même mesure, le cercle de la vie sociale s'est étendu (DURKHEIM, 1895a, p. 140).

Aplicando essa razão à dupla morfologia esquimó, observa-se como o grau de coalescência dos segmentos sociais é relativamente baixo no verão, ao passo que, no inverno, ele chega ao seu máximo, dissolvendo todos os segmentos sociais em uma única sociedade. Assim, se no verão a vida social é menos densa, mais dispersa e mais individual, a vida ordinária e profana tende ao primeiro plano. Ao contrário, no inverno, o estado de comunhão e de unidade moral e religiosa é tão intenso que a vida coletiva toma o primeiro plano da vida social, a ponto de Mauss e Beuchat o denominarem como estado de efervescência e superexcitação da sociedade esquimó. Ao se adensarem, as interações se tornam mais numerosas, frequentes e contínuas; as pessoas envolvidas 
tomam consciência da ação coletiva, pois experimentam in loco a força sagrada em ação. Nesse contexto, a introdução do termo efervescência retoma Le suicide, quando Durkheim também o utilizou para explicar as variações sazonais dos suicídios na Europa $^{20}$. Para refutar a influência de fatores ambientais que explicassem o maior número de suicídios durante o verão em comparação com o inverno, Durkheim afirma que "si le jour est le moment de la journée qui favorise le plus le suicide, c'est que c'est aussi celui où la vie sociale est dans toute son effervescence" e, por conseguinte, "les variations mensuelles ou saisonnières du suicide dépendent de l'inégale intensité de la vie collective" (DURKHEIM, 1897a, p. 102 e 104). Guardadas as devidas diferenças, é possível observar como Mauss e Beuchat aplicam o mesmo tipo de raciocínio empregado por Durkheim para atribuir a preponderância da dinâmica da vida coletiva contra explicações extrassociais: em ambos os casos, a explicação da variação sazonal liga-se intimamente à dinâmica dos momentos de efervescência e calmaria que ditam o ritmo da vida coletiva. Ademais, do ponto de vista especificamente religioso, Mauss já estava atento a como os momentos de efervescência eram particularmente relevantes para os fenômenos de origem e de unidade das coletividades. Em uma resenha de 1899 sobre a origem do culto cristão, Mauss criticara o autor da obra por ignorar a difusão original promovida pelas comunidades cristãs primitivas e, particularmente, por sua “effervesence interne. Ce qui a existé, semble-t-il, ce sont des Eglises chrétiennes, ayant chacune une vie autonome et agissant les unes sur les autres. [...] C'est des ces actions et des réactions mutuelles qu'est sortie l'unité chrétienne" (MAUSS, 1899b, p. 270). Nesse sentido, tanto no caso dos esquimós quanto no do cristianismo primitivo, os estados de efervescência coletiva constituem momentos propícios para a criação e recriação das ideias, sentimentos e práticas comuns que constituem a própria imagem do grupo; momentos esses que só são possíveis quando o grau de coalescência dos segmentos sociais atinge o seu apogeu.

Como os apontamentos a respeito dos fenômenos de efervescência observados em outros lugares sugere, apesar dessa alternância respeitar um ritmo tão regular entre os esquimós, não se trata de um fenômeno exclusivo desses grupos e possui, portanto, uma

20 A esse respeito, Watts Miller (2000, p. 10) questiona se foi Durkheim quem realmente introduziu o termo na obra de 1897, considerando i) que este nunca mais foi utilizado pelo autor até reaparecer em Les Formes élémentaires de la vie religieuse; e ii) que Mauss colaborou, até onde se sabe, para a tabulação dos dados utilizados na obra de 1897. 
generalidade muito maior. Em boa parte do continente norte-americano e, particularmente, na civilização do noroeste, as sociedades indígenas como os Kwakiutl observam variações sazonais semelhantes: "En été, [...] le sacré est en dessous, le profane est en haut; en hiver, le sacré est au-dessus, le profane en dessous" (BOAS apud Mauss; Beuchat, 1906, p. 126). Mesmo as sociedades europeias, como Durkheim já havia notado a respeito do suicídio, experimentam tais oscilações: as festas religiosas no interior durante o verão, que coincidem com as férias na cidade e com o período de dispersão urbana. Retomando as estatísticas relativas ao suicídio e ao homicídio na Europa, Mauss e Beuchat afirmam que os suicídios - produto urbano - crescem do final do outono até junho, ao passo que os homicídios - produto rural - aumentam do começo da primavera até o fim do verão. Reconhecendo, então, se tratar de uma lei social de grande generalidade, os autores tentam esboçar a causa desse ritmo da vida coletiva:

La vie sociale ne se maintient pas au même niveau aux différents moments de l'année ; mais elle passe par des phases successives et régulières d'intensité croissante et décroissante, de repos et d'activité, de dépense et de réparation. On dirait vraiment qu'elle fait aux organismes et aux consciences des individus une violence qu'ils ne peuvent supporter que pendant un temps, et qu'un moment vient où ils sont obligés de la ralentir et de s'y soustraire en partie. De là ce rythme de dispersion et de concentration, de vie individuelle et de vie collective, dont nous venons d'observer des exemples (MAUSS; BEUCHAT, 1906, p. 127).

Os autores atribuem a causa desse ritmo, em primeiro lugar, à violência que a vida social imprime nos indivíduos e à capacidade limitada que estes têm de suportá-la indefinidamente, demandando períodos subsequentes de subtração e ausência das atividades do grupo. Mas a conclusão do ensaio também sugere uma explicação mais ampla, ligada à relação dinâmica entre a morfologia e a fisiologia dos fenômenos sociais. Conforme Durkheim enfatizava desde o princípio no Année, o estudo da morfologia social não considera somente o substrato social formado, mas antes "l'observe en voie de devenir pour faire voir comme il se forme", ou seja, "elle comprend tout naturellement les mouvements d'où résultent les états qu'elle étudie" (DURKHEIM, 1899c, p. 521). Ele mesmo já havia realizado semelhante empreendimento quando mostrou em De la division du travrail social a evolução do direito penal e do direito civil em função do tipo morfológico das sociedades; ou, ainda, em Le suicide, o desenvolvimento das crenças individualistas em função do grau de integração ou 
desintegração dos grupos sociais. Todavia, em todos esses casos era difícil fornecer uma experimentação, ainda que indireta, que não deixasse dúvidas quanto a como as formas da vida social variam de acordo com o substrato desta última; e é precisamente essa dificuldade que o estudo sobre os esquimós conseguiu contornar ao fazer com que fosse possível observar, por meio da aplicação do raciocínio experimental, os momentos em que a forma de agrupamento muda e, simultaneamente, a religião, o direito e a moral do grupo $^{21}$.

\subsection{Conclusão}

Ao analisarmos a contribuição de Mauss para o estudo dos fenômenos religiosos durante o período contemplado, pudemos constatar como o autor foi responsável pela emergência da abordagem da sociologie religieuse. Por conseguinte, Mauss encarregouse da circunscrição do material etnográfico das sociedades elementares e das técnicas de análise dessas etnografias, além da consequente construção dos fenômenos a serem observados; Mauss também selecionou as principais referências teóricas do debate, avaliando os temas e as ferramentas teóricas úteis para a intervenção da sociologia nesse domínio. Baseado em uma reinterpretação crítica tanto da sociologia durkheimiana quanto da história e antropologia das religiões vigente, Mauss acabou por estabelecer tanto uma linguagem quanto uma interpretação sociológica específica para a investigação dos fenômenos religiosos. De tal abordagem, cuja elaboração perpassa todos os trabalhos analisados, emerge a teoria do drama sagrado, que sublinha o caráter intelectual e estético da ação ritual, capaz de transformar ideias e práticas sociais e criar, por assim dizer, novas realidades. Tomando a relação entre mito e rito como unidade de análise, Mauss caracteriza os aspectos do drama sagrado por meio das noções de figuração, poder e ritmo. Entendido como uma faculdade de associação, o ritmo, cuja expressão estética mais comum são os cantos em coral e as danças coletivas, realiza-se por meio da agitação repetitiva e sincrônica de gestos e sons, produzindo, assim, uma espécie de alinhamento que culmina na unidade entre todos os participantes. Já as figurações consistem em expressões simbólicas dos mitos por meio de ideogramas rituais, isto é, por meio de pinturas corporais, adornos, máscaras, mas, principalmente, de atuações cênicas de determinadas cenas míticas durante as cerimônias públicas.

21 Para uma avaliação da influência de Mauss para os Inuit studies, cf. o volume especial organizado por Bernard Saladin d'Anglure (2006). 
Produzindo um meio social especial, diferente e separado da vida ordinária, a atividade estética referida engendra os estados afetivos de êxtase, nos quais os participantes das cerimônias entram em contato com um poder de estranha intensidade que dissolve as consciências individuais, criando uma unidade em torno de certa ideia comum a todos. Essa força afetiva, gerada durante o drama ritual, nada mais é que a força sagrada, que é experimentada in loco pelos participantes em tal intensidade que gera mesmo a sensação de que estes vivem uma nova realidade. O sagrado é, portanto, a noção que torna inteligível esse poder coletivo extraordinário, engendrado em circunstâncias também excepcionais, capaz de criar crenças e práticas por meio da ação ritual dramática. Por conseguinte, a combinação entre ritmo, figuração e êxtase na manipulação das forças sagradas é caracterizada pelo estado de efervescência coletiva, que sublinha o papel dos elementos afetivos e estéticos durante os rituais. Dessa maneira, a efervescência coletiva é a noção que sintetiza o mecanismo do drama sagrado. Tal qual elaborada por Mauss, a teoria do drama sagrado marca, portanto, o ponto de inflexão da sociologia durkheimiana e o advento da sociologie religieuse.

Não obstante, o percurso que produziu a teoria do drama sagrado foi acompanhando por outros desenvolvimentos necessários para a emergência da nova abordagem. Do ponto de vista metodológico, o objeto de análise selecionado foi fundamentalmente o material etnográfico disponível acerca dos povos australianos, melanésios e norteamericanos. A esse respeito, Mauss advoga em favor da crítica documental - isto é, da necessidade de explicitar as circunstâncias de observação e de realizar uma comparação entre diferentes documentos sobre um mesmo grupo - como ferramenta útil para a análise dos documentos etnográficos. À diferença do interesse do antropólogo ou do historiador, o interesse sociológico nas etnografias reside na investigação dos fenômenos inconscientes e elementares que estão inscritos na tradição coletiva do grupo e que são articulados de maneira indireta nos dados de superfície. Dessa maneira, Mauss esclarece que as regras relativas à definição e à observação dos fenômenos sociais são, na realidade, regras da constituição desses fenômenos por parte do pesquisador. Na abordagem sociológica, os ritos e mitos são os símbolos exteriores, imediatamente acessíveis à observação, que tornam inteligíveis suas relações com os demais fenômenos sociais e permitem, assim, a construção de definições científicas e a consequente explicação dos fenômenos religiosos, bem como a possibilidade de 
estabelecê-los em um sistema racional. Segundo Mauss, isso é possível por meio da comparação metódica ou da aplicação do raciocínio experimental, ou seja, por meio da comparação entre as variações concomitantes e da consequente ordenação lógica desses fenômenos religiosos dentro de um sistema mais amplo de fenômenos sociais. Entendidas dessa maneira, as regras de observação e explicação pretendem estabelecer uma sociologia evolucionária que tem por objetivo conhecer a gênese e o desenvolvimento das ideias e práticas religiosas.

Do ponto de vista teórico, a abordagem desenvolvida por Mauss privilegia a relação entre ideias e práticas religiosas ou, mais especificamente, a unidade formada por mito e rito: avesso à abordagem intelectualista e individual predominante em ciência das religiões, Mauss identifica no par mito-rito a unidade de análise das formas elementares dos fenômenos religiosos, formas estas que estão inscritas na tradição coletiva das sociedades. Tal foco nos rituais religiosos permitiu a Mauss encontrar na noção de sagrado o princípio ordenador das crenças e práticas religiosas; a noção de sagrado possui correspondentes análogos em todas as sociedades estudadas e tem a concepção de mana como germe. Nesse sentido, desde seu primeiro trabalho, Mauss introduz a noção de sagrado para explicar o tabu polinésio: antes de denotar o sistema de interdições, a noção de tabu diz respeito ao conjunto de regras que existem e são seguidas muito antes de ser possível conceber a possibilidade de violá-las. Entendida dessa maneira, a noção de tabu simboliza o conjunto de crenças e práticas sagradas, isto é, o conjunto de práticas marcadas como separadas, sobrenaturais e transcendentes, que se opõem a tudo o que é profano, ordinário e comum. Força altamente contagiosa e marcada por uma inerente dualidade entre pureza e impureza, pode servir tanto à veneração quanto ao malefício: seja no sacrifício, seja na magia, o contato e a manipulação das forças mana ou sagradas objetiva a transformação mágico-religiosa de seres e coisas por meio da ação dramática. O meio pelo qual tal força transformadora sagrada se realiza consiste no conjunto de elementos que configuram a linguagem estética e afetiva da ação ritual, quais sejam, a figuração, o drama e o ritmo, que funcionam tanto como meio de consagração quanto de elaboração de uma linguagem compartilhada durante os estados de efervescência coletiva. Nesse sentido, Wendy James já havia assinalado a centralidade do drama na abordagem de Mauss a respeito dos fenômenos de eferverscência coletiva: 
Large gatherings may be a direct stimulus and thus lead to the heightened emotional experience dubbed by [...] 'effervescence'; but what are such gatherings, beyond simply being crowds? They are sites for the performance of spontaneous drama; of representational play, sound, and action which relate to worlds removed from the immediate present, whether to the presence of the gods or to some political utopia (JAMES, 2014, p. 80).

Ao depreender o mecanismo da ação coletiva dramática, Mauss demonstra sua particular pertinência para interpretar cerimônias mágico-religiosas públicas nas sociedades elementares - desde as cerimônias de iniciação àquelas de reprodução da espécie totêmica -, momentos extraordinários durante os quais os estados de eferverscência coletiva engendrados no drama sagrado criam realidades: isto é, produzem uma forma de expressão puramente coletiva e abstrata que tanto celebra e revitaliza o poder das crenças e práticas do grupo quanto pode, eventualmente, dar origem a novas ideias e práticas.

No que concerne à dinâmica da vida coletiva, os dramas sagrados são periódicos e intercalados por momentos de vida ordinária e profana. Por conseguinte, a alternância cíclica entre concentração e dispersão do sagrado, característica das festas e celebrações periódicas, tem como produto aquilo que Mauss denominou por lei do ritmo da vida coletiva. Temos, portanto, a noção de ritmo como uma categoria coletiva que opera simultaneamente em dois planos: i) nos dramas sagrados, nos quais o ritmo funciona como categoria de associação harmônica entre pessoas para a produção de uma linguagem coletiva; e ii) na dinâmica cíclica da vida coletiva, produzida pela sucessão regular de tempos fortes e fracos, isto é, sagrados e profanos, ao longo de determinado período. Essa lei dinâmica é explicada pela relação entre morfologia e fisiologia social, isto é, pelo modo como as formas da vida social variam de acordo com seu substrato. Nesse sentido, os períodos sagrados são aqueles durante os quais os vínculos sociais se adensam, as interações se tornam mais numerosas, frequentes e contínuas e o estado de comunhão é tão intenso que a vida coletiva toma o primeiro plano. Quando a vida social atinge tal intensidade, o grau de coalescência atinge seu ápice e aglutina os diferentes segmentos sociais, formando uma grande e única sociedade. Ao contrário, durante os momentos de vida ordinária e profana, a vida social passa a ocupar o segundo plano e o grau de coalescência declina, reforçando a segmentação social. Mas além da dinâmica cíclica dos tempos sagrado e profano, tópico especialmente desenvolvido por Hubert, 
Mauss constrói uma análise genética dos fenômenos religiosos se utilizando do conhecimento etnográfico e identificando a posição das sociedades dentro de sua própria história para, daí, reconstruir retrospectivamente a origem desses fenômenos religiosos. Por considerar não haver nenhuma sociedade em tal estado originário, esse recurso foi empregado largamente por Mauss tanto na crítica à abordagem dos antropólogos britânicos quanto na inferência acerca dessas manifestações religiosas originárias. O desenvolvimento dos fenômenos sociais elementares é igualmente importante: dos dramas sagrados de origem, passando pelos rituais e festas dos grupos totêmicos em decomposição, Mauss também indica alguns traços da história evolucionária das crenças e práticas mágico-religiosas que estão na origem de fenômenos modernos. Tal história compreende: i) o desenvolvimento da moderna noção de sagrado a partir das diversas categorias locais de força mágico-religiosa, como as de mana e tabu; a origem da noção de deidade a partir dos cultos totêmicos; ii) a separação e especialização entre magia e religião e a origem mágico-religiosa não apenas das representações individuais, mas também da ciência e das técnicas, a partir da noção de causalidade não mecânica. Ainda que esses desenvolvimentos sejam incipientes e parciais, eles indicam um vetor para a história universal, qual seja: a homogeneização das categorias coletivas de pensamento, tendência identificada por Allen (2000, p. 3234; 2014, p. 26). Dessa maneira, a identificação de tal tendência evolucionária é o que permite a Mauss pensar as noções indígenas de forças mágico-religiosas como protótipos da moderna noção de sagrado, bem como as noções indígenas qualitativas e descontínuas de espaço sagrado como protótipos da noção científica, quantitativa e contínua de espaço. Para Mauss, portanto, importa não só investigar os fenômenos religiosos elementares, mas pensar suas transformações em relação a seu devir moderno.

Por fim, resta comparar as abordagens desenvolvidas por Durkheim e Mauss e extrair dessa primeira comparação uma conclusão, ainda que parcial, a respeito da direção tomada pela sociologie religieuse em relação à sociologie morale et juridique. Em primeiro lugar, pudemos constatar que Mauss segue de perto o esquema metodológico desenvolvido por Durkheim para a sociologia, da observação à explicação, e o aplica tal qual para os fenômenos religiosos. Tais regras são fundamentais para demarcar as abordagens que advogam a possibilidade de explicação 
científica dos fenômenos humanos e, dentre essas, aquelas que advogam a pertença dos fenômenos religiosos ao domínio dos fenômenos sociais, irredutíveis à explicação psicológica individual. Além disso, vimos como Mauss acaba por preencher uma lacuna da metodologia durkheimiana acerca da observação e da análise científicas de fatos etnográficos - algo até então inédito para a sociologia durkheimiana. Todavia, é interessante notar como tamanha afinidade metodológica não se reproduziu no plano teórico e, particularmente, como tal desacordo demorou para ser percebido por Durkheim: este pensava o trabalho do sobrinho à frente da seção de sociologie religieuse como um coroamento de sua abordagem anterior. Isso fica particularmente claro na discussão sobre o tabu polinésio e sobre o sacrifício. No primeiro caso, Durkheim reconhece a noção de tabu como a grande contribuição do primeiro trabalho de Mauss - e chega a incorporá-la a seu artigo sobre a origem da proibição do incesto; mas, ao mesmo tempo, restringe o significado da noção de tabu exclusivamente às interdições rituais, isto é, às sanções ou aos constrangimentos gerados no seio das instituições religiosas. O segundo caso, relativo ao sacrifício, corrobora a mesma linha de raciocínio: Durkheim esperava que a grande contribuição do artigo de Hubert e Mauss fosse a de desvelar a pena como ideia capital da noção de sacrifício, enfatizando os elementos de destruição e obrigação que seriam inerentes à prática sacrificial. Dito de maneira breve, Durkheim esperava que a sociologie religieuse servisse de corolário para sua teoria da origem religiosa das sanções morais e jurídicas. Entretanto, vimos que a abordagem elaborada por Mauss a partir desses textos não trilhou a rota esperada por Durkheim e, ao contrário, encaminhou-se na direção oposta, ainda que partindo de um ponto comum. De acordo com Mauss, nas sociedades elementares o funcionamento das regras precede o advento das sanções, consideradas um produto relativamente tardio da evolução religiosa; ou seja, as regras são seguidas sem a necessidade de sanções pois os membros do grupo as respeitam e as seguem acima de qualquer suspeita. Isso leva Mauss a questionar a natureza da adesão e do sentimento de deferência imediatos que as coisas tabu implicam aos polinésios, concluindo que é porque as coisas são sagradas que elas são chamadas tabu. E foi somente durante a concepção do ensaio sobre o sacrifício que as diferenças entre ambas as abordagens ficaram explícitas: ou seja, para Mauss, é a noção de sagrado - e não a de pena - que está por trás de todo rito sacrificial, e estudar o mecanismo desse rito é estudar não sua capacidade de destruição, mas de 
transformação de seres e coisas por meio da manipulação dramática do sagrado. Desde então, o sagrado passou a definir não só a força manipulada nas cerimônias, mas o próprio domínio espaço-temporal da ação religiosa. Em colaboração com Hubert, Mauss deparou-se com a magia, considerada um verdadeiro problema anômalo para a abordagem desenvolvida por Durkheim, por se tratar de um fenômeno individual e facultativo, ao qual a ideia de obrigação moral é totalmente estranha. Mais uma vez, Mauss fez uso do instrumental durkheimiano para identificar a noção de mana como categoria coletiva responsável pela eficácia dos fenômenos mágicos; mas vai além, identificando não só a categoria de mana como categoria origem de todos os fenômenos mágico-religiosos, como também as cerimônias públicas elementares que estão na origem da produção dessas categorias coletivas. Portanto, se para a sociologie morale et juridique a religião era concebida como uma forma de disciplina social, a sociologie religieuse concebe o domínio religioso a partir de sua capacidade de transformar estados e coisas por meio da ação dramática.

Não obstante, esse desacordo explícito é acompanhado por outros dois desacordos, implícitos e relacionados, a saber: i) acerca da relevância dos símbolos religiosos para a análise sociológica; ii) acerca do compromisso ético da sociologia com o Esclarecimento. A esse respeito, vimos que Durkheim considera os símbolos relevantes para a análise quando estes expressam objetivamente sentimentos de solidariedade fundamentais, como quando o direito ou os costumes simbolizam a moral. Por exemplo, a sanção legal ou difusa simboliza exteriormente a violação de uma regra moral, que não é, por sua vez imediatamente acessível à observação. Por outro lado, Durkheim nega a relevância da análise dos símbolos e das emoções e religiosas por considerá-los um produto subjetivo e ideológico do senso comum, isto é, uma maneira ideológica e irracional dos nativos explicarem sua própria crença; sendo subjetivos, os símbolos religiosos são considerados invólucros superficiais e dispensáveis, um resíduo a ser extirpado no decurso da evolução religiosa em direção a uma crença moral cada vez mais racional e transparente. Ao proceder dessa maneira, Durkheim sustenta não somente um juízo de fato sobre uma tendência evolucionária, mas também um juízo de valor: isto é, de que a sociologia deve contribuir para eliminar o misticismo religioso e sua parafernália simbólica da discussão por meio de explicações que tornem transparentes os elementos racionais e morais que regem o funcionamento da religião: 
ou seja, as regras de conduta obrigatórias que constituem o núcleo da vida social. Ao almejar que a sociologia seja um instrumento a serviço da realização do ideal iluminista de transparência das relações sociais e morais, a abordagem da sociologie morale et juridique pode ser caracterizada como uma sociologia da transparência. Ao contrário, o projeto elaborado por Mauss é baseado na possibilidade de analisar objetivamente os fenômenos religiosos e demonstrar como seu substrato social se expressa nas mais variadas manifestações simbólicas desses fenômenos: desde a seleção do par mito e rito como unidade privilegiada de análise, Mauss demonstra como as cerimônias articulam elementos estéticos e afetivos, tais como drama, êxtase, figuração e ritmo, considerados símbolos objetivos dos processos de transformação mágico-religiosa de seres e coisas. Seguindo essa análise, Mauss conjectura sobre como as cerimônias públicas das sociedades elementares não só expressam uma linguagem social, como também desencadeiam os estados de efervescência coletiva responsáveis pela criação in loco das ideias e práticas sociais. Assim, apesar de ser igualmente partidário do legado iluminista da ciência positiva, Mauss demonstra como o compromisso ético de Durkheim com o ideal de transparência constitui, na verdade, um obstáculo para o conhecimento objetivo dos fenômenos religiosos, uma vez que simplesmente deixa de considerar tudo aquilo que a ciência deveria explicar: os ritos, os mitos, o êxtase e todo o universo simbólico relacionado. Com efeito, a emergência da sociologie religieuse institui uma nova abordagem, que sublinha a capacidade da linguagem afetiva e estética da ação ritual de transfigurar as forças sociais em ação. Assim, ao estabelecer uma abordagem que investiga o mecanismo de transfiguração inerente à criação das ideias e práticas coletivas, a sociologie religieuse pode ser caracterizada como uma sociologia da transfiguração. 


\section{Capítulo 3. \\ Hubert e o desenvolvimento da sociologie religieuse: o drama sagrado das festas sazonais à literatura épica}

No presente capítulo, pretendemos analisar a contribuição de Henri Hubert ${ }^{1}$ para a análise sociológica dos fenômenos religiosos, tomando por referência o período de desenvolvimento da sociologie religieuse enquanto editor do Année sociologique. Tal período compreende a publicação do verbete "Magia" (1902), de seu trabalho mais conhecido, "Étude sommaire de la représentation du temps dans la religion et la magie" (1905), bem como o artigo "Le culte des héros et ses conditions sociales" (1914). A seleção dos trabalhos analisados compreende todos os artigos, resenhas e cursos que tratam diretamente da religião e dos fenômenos religiosos e que foram publicados até 1915. Nesse sentido, a nossa análise investiga como Hubert contribui para o desenvolvimento da sociologie religieuse durante o período, particularmente no que diz respeito à ênfase no caráter estético das ideias e práticas religiosas elementares. Conforme pretendemos demonstrar, Hubert é responsável tanto pela análise das festas sazonais como dramas sagrados que que conformam a noção coletiva de tempo, quanto pela investigação da literatura épica como produto do processo de secularização desses dramas rituais.

O capítulo está subdividido em cinco partes. Na primeira, apresentaremos a abordagem de Hubert para os fenômenos mágicos e a relação destes com a religião e a sociedade a partir do contexto greco-romano. Na segunda, trataremos do balanço de Hubert sobre a história e ciência das religiões, bem como sua defesa da sociologie religieuse como a ciência comparada das religiões. Na terceira parte, analisaremos seu ensaio sobre a representação do tempo mágico-religioso, enfatizando a emergência da noção de tempo sagrado e do calendário a partir das festas sazonais. Na quarta, discutiremos a origem religiosa da mitologia heroica e o seu desenvolvimento até a depuração estética da figura do herói na literatura épica. Por fim, na quinta parte,

1 Para um panorama da vida e obra de Hubert, cf. Laurent Oliver (2017). 
retomaremos as etapas da reflexão de Hubert para avaliar a sua contribuição para o desenvolvimento da sociologie religieuse.

\subsection{A magia e a religião na Antiguidade greco-latina}

Em 1901, Hubert se torna professor da École Pratique des Hautes Études (EPHE) e inaugura a cadeira intitulada "Religions primitives de l'Europe", dedicada ao estudo dos fenômenos religiosos desde os povos indígenas da Europa Ocidental, os Celtas e os Germânicos, passando pela Antiguidade greco-latina até a consolidação do cristianismo na Idade Média. Durante esse período, Hubert se engaja, assim como Mauss, no estudo da magia, ministrando seus primeiros cursos na EPHE sobre o assunto. Paralelamente, Hubert escreve o verbete "Magia", publicado em uma separata em 1902 e em 1904 no Dictionnaire des antiquités grecques et romaines. No verbete, Hubert afirma que apesar da magia ser nomeada de muitas maneiras diferentes entre gregos e romanos, os vários termos listados designam uma mesma classe de fenômenos que é passível de ser definida e investigada em conjunto. Não obstante, Hubert adverte que "cette définition provisoire ne s'applique pas exclusivement à l'antiquité gréco-latine" (HUBERT, [1902] 1904, p. 1494). Sendo assim, a partir da análise de um conjunto determinado de fenômenos, Hubert pretende extrair conclusões que possam ser generalizadas para todo o domínio dos fenômenos mágicos.

O problema fundamental da definição consiste em conseguir distinguir magia de religião, cujo limite é difícil de traçar, reconhece Hubert, já que nem o objeto, nem a forma, permitem distinguir a priori os ritos mágicos dos ritos religiosos. Ainda assim, Hubert observa uma distinção de ordem jurídica entre magia e religião que ainda não havia sido claramente enunciada, a saber: que a magia é "essentiellement illicite, sinon criminelle", o que é atestado pela noção de crime mágico, atribuindo a algumas "cérémonies sacrées" a qualificação "d'impies, d'illicites, de nocturnes et de clandestines" (HUBERT, [1902] 1904, p. 1496-1497), enquanto a noção de crime religioso restou sem qualquer contorno mais preciso. Dessa maneira, “c'est l'autorisation légale qui sépare le religieux du magique" (HuBERT, [1902] 1904, p. 1497). Mas como, e por que, os atos mágicos são considerados ilegais? Em uma resenha do ano anterior, Hubert já havia apontado como a relação do Estado romano e o colegiado de pontífices havia criado essa separação legal entre religião e magia, que 
dispõe do poder do Estado somado ao poder sagrado para diferenciar as religiões oficiais daquelas que, ilegais, se tornaram mágicas:

L'étude de la religion romaine montre, avec une clarté parfaite, l'intime connexion des idées d'autorité sociale et de sacré à un certain étage du développement des religions. L'unité de l'État fait l'unité des cultes et les rassemble en un seul faisceau. Le collège des pontifes symbolise l'unité des choses sacrées et en dispose. Les autorités religieuses officielles, d'accord avec les pouvoirs de l'État, décrètent ou sanctionnent l'introduction des cultes nouveaux. C'est leur décision qui fixe la séparation du religieux et du magique (HUBERT, 1901f, p. 293; grifo nosso).

Sendo assim, o colegiado de pontífices simboliza a unidade das coisas sagradas e pode, por essa razão, legislar sobre o que pode ou não ser considerado religião. Parafraseando Cícero, Hubert afirma que a magia é ilegal "parce que ses rites sont étrangers" ([1902] 1904, p. 1500). Nesse sentido, são os ritos religiosos desenraizados e transplantados para outro espaço-tempo que são classificados como mágicos, atribuindo essa alcunha a toda sorte de atos heterogêneos cuja única característica comum é justamente a de serem práticas religiosas estrangeiras no novo lugar em que estão inseridas. Isso é atestado por diversos exemplos, que vão desde a introdução das religiões orientais no mundo grego até a emergência do cristianismo como religião oficial romana e a consequente perseguição das religiões dos povos considerados bárbaros ${ }^{2}$. Em uma resenha do Année, Hubert exemplifica que a introdução da astrologia oriental no mundo grego antigo foi tida no novo contexto como ciência perigosa e foi colocada à margem da sociedade grega, de tal maneira que "[1]'astrologie ne fut pas très longue à tomber dans la magie" (Hubert, 1901b, p. 188). Com efeito, o caráter ilegal de determinadas religiões estrangeiras é traduzido por esse outro esquema de pensamento como magia:

Il en résulte que la magie ne se distingue point de la religion par le caractère miraculeux de ses effets ou le mécanisme de ses procédés, mais par ce qu'elle présente d'anormal en un point donné de l'espace ou du temps et d'incompatible avec le système des idées reçues et des images coutumières (HUBERT, [1902] 1904, p. 1500).

2 O caso do cristianismo é complicado, segundo Hubert ([1902] 1904, p. 1502), pelo fato dos cristãos terem uma longa relação com a magia mística que muito contribuiu para sua propagação. Essa longa relação só foi interrompida com o nascimento da Igreja e o consequente status de religião oficial. Daí, segundo Hubert em uma resenha (1902c, p. 229-233), a Igreja passou a ter um papel capital na classificação de práticas religiosas estrangeiras como mágicas e, consequentemente, como crime religioso. 
Seguindo o raciocínio de Hubert, portanto, a ilegalidade da magia se fundamenta no desenraizamento de religiões que, ao serem transportadas de seu lugar de origem para outro, são interpretadas como anormais e então classificadas como manifestações mágicas locais.

De maneira geral, a ação mágica pode ser dividida entre os métodos direto, cujo efeito resulta imediatamente do cumprimento do rito, e indireto, cuja ação recai sobre os seres sobrenaturais que lhe servem de meio de ação. Forma dominante na magia grecoromana, o método indireto, baseado em uma teoria como a demonologia, atribui a produção de determinado efeito à ação de uma potência espiritual consciente, o demônio, que é responsável por produzir o efeito a partir de um ato mágico. Já o método direto é aquele que se baseia no princípio da ação simpática, isto é, em que a contiguidade e a semelhança produzem identidade. Apesar de recobrir como a lei simpática atua por meio de diversos ritos e objetos, o foco de Hubert está nos ritos de encantamento, designados por ele como atos simbólicos, cujo papel desempenhado consiste naquele "de créer ou de représenter le pouvoir magique" (HuBERT, [1902] 1904, p. 1519). Com efeito, a palavra e o som sobrepõem-se ao sentido; por meio da repetição, dos jogos de palavras, o sentido é reduzido a fórmulas e enigmas, isto é, a representações figuradas do poder mágico. Como conclui Hubert; "En résumé, l'incantation tend à passer de l'intelligible à l'inintelligible et à se transformer en chose magique contenant sa vertu en elle-même" (HuBERT, [1902] 1904, p. 1519). Essa capacidade de transformar o inteligível em ininteligível, de subordinar o conteúdo à forma, de representar figurativamente ou, enfim, de transformar o sentido ordinário pelo uso de símbolos: nisso reside a forma de expressão mais elementar do poder mágicoreligioso.

Outra questão importante diz respeito à iniciação do mágico: por um lado, a iniciação não como uma simples comunicação ou transmissão de receitas, mas por uma revelação cosmológica cujo "caractère sacré de la doctrine est protégé par le secret" (HuBERT, [1902] 1904, p. 1510). Ao introduzir o sagrado como um caráter tanto das doutrinas mágicas quando das cerimônias, estamos novamente às voltas da relação entre magia e religião que, segundo Hubert, não é nem surpreendente nem estranha, visto que ambas são praticamente indistintas na origem e mantêm, desde então, uma relação permanente. 
Depois de ter distinguido magia de religião pelo seu caráter jurídico, bem como de ter mostrado que, apesar dessa distinção, religião e magia mantêm uma relação contínua, falta esclarecer conceitualmente qual é o domínio de ação de cada uma. A partir de uma origem comum, ambas se diferenciaram e passaram a ocupar espaços distintos que, consequentemente, configuram modos diferentes de manipular os mesmos elementos. Conforme Hubert:

C'est précisément l'absence de l'élément société [...] qui distingue la magie de la religion [...] C'est que l'être religieux, le dieu, n'est pas une force libre ; il est qualifié par la société ; les besoins de la société lui ont fixé ses fonctions ; on a déterminé sa vie, son mode d'action, et s'il ne se soumet pas exactement dans son mythe aux lois morales fixées par la société, celles-ci dominent expressément la pratique du culte et ses effets. L'être magique est une force libre, enchaînée par la magie seule. Les dieux qu'elle invoque sont des dieux déracinés ; [...] Or, pour une religion fortement organisée, les esprits qui restent en dehors du culte tendent à devenir des démons au sens chrétien. La magie se meut sur la lisière de la société ; souvent elle en prend le contre-pied. Elle parait avoir pour objet spécial de dépasser les limites fixées par la religion, et d'abuser des forces saisissables. L'impur, le contre-nature, tout ce qui est craint et interdit, tout ce qui n'est pas spécialisé et organisé, lui est dévolu (HUBERT, [1902] 1904, p. 1514).

De acordo com o autor, a relação com a sociedade é o critério último que distingue conceitualmente magia e religião. Por um lado, a religião organiza-se na e pela sociedade, submete-se às suas regras e é, por assim dizer, a própria ideia de organização no domínio religioso. A ação religiosa, portanto, "semble être préalablement indiquée par la constitution, la vie et les besoins de la société" (HUBERT, [1902] 1904, p. 1521). Por outro lado, Hubert afirma em uma das resenhas que "la magie suppose la société religieuse" (1902d, p. 233), na medida em que se apropria das forças religiosas, mas as subordina aos seus fins particulares: a magia está sempre em uma relação marginal com a sociedade e dirige-se, no limite, contra a própria ideia de organização, excedendo os limites da religião. Para Hubert, portanto, a magia e a religião se diferenciam em razão de suas diferentes funções na vida social.

\subsection{Da história das religiões à sociologie religieuse}

Em 1904 vem a público a tradução francesa do Manuel d'histoire des religions de Pierre Daniel Chantepie de la Saussaye, dirigida por Henri Hubert e Isidore Lévy. O manual contém uma longa introdução de Hubert (1904), considerada um dos primeiros 
balanços da sociologia da religião durkheimiana. Na introdução, Hubert justifica sua iniciativa pela tentativa de estabelecer uma ciência da religião mais sistemática, que possa fazer uso da historiografia vigente. Com efeito, o manual tem o mérito de considerar os fatos históricos da religião como passíveis de tratamento científico: "L'histoire des religions s'achève en science ; elle prépare les matériaux d'une science" (Hubert, 1904, p. XVI). Dessa maneira, a partir dos fatos constatados, descritos e classificados pelo historiador da religião, cabe ao cientista da religião explicá-los, preocupando-se com as causas e consequências, com a origem e a função dessas instituições.

Ao traçar a emergência da sociologie religieuse, Hubert menciona outra escola de pensamento que também não figura no manual: trata-se da escola antropológica britânica, formada, dentre outros, por Robertson Smith e James Frazer. Por um lado, Hubert reconhece a importância da escola para a ciência das religiões, por ter apreendido os caracteres mais evidentes das religiões mais desenvolvidas - seja por meio do estudo do folclore, seja por meio das análises etnográficas. Por outro lado, cumpre mostrar os limites da abordagem proposta pelos antropólogos britânicos que, ao desprezarem os fatos históricos, tentam explicar por leis de validade pretensamente universal a suposta identidade da natureza humana. Conforme resume Hubert, mordaz: "Les savants de cette école ont été frappés par la répétition universelle et spontanée des mêmes phénomènes. Pratiques et croyances se reproduisent à l'infini comme les images que se renvoient deux miroirs opposés" (HuBERT, 1904, p. X). Exclusivamente preocupados com a investigação da origem dos fenômenos mais primitivos e, principalmente, negligenciando qualquer preocupação com a função específica de cada instituição investigada, o pretenso método comparativo empregado pelos antropólogos britânicos acaba por fazer uma justaposição cumulativa de fenômenos das mais diferentes instituições, chegando a conclusões frequentemente equivocadas e explicações insuficientes. A esse respeito, Hubert esclarece em uma resenha que o estudo "des phénomènes religieux, en tant que phénomènes se produisant également dans plusieurs sociétés et étudiés comparativement" é um estudo especial que exige do pesquisador "apprendre si lié comparer entre eux que des faits comparables" (HUBERT, 1907a, p. 284), evitando, assim, aquilo que faziam os antropólogos britânicos. Em sua resenha sobre The Golden Bough, Hubert já havia criticado o que designou por método 
discursivo de Frazer que, ao deixar em segundo plano a conexão dos fenômenos com as respectivas sociedades que os produzem, acaba por retirar Frazer do caminho da ciência (HUBERT, 1901, p. 279-281). Hubert atribui essas limitações ao excesso de empirismo desses trabalhos, que valem mais pela massa de fatos que reúnem que pelo método empregado ou pela interpretação que propõem. Ainda assim, reconhece que foi a partir da leitura da antropologia britânica que a sociologie religieuse, "où la critique est plus longue que la théorie" (HuBERT, 1904, p. XIII), tornou-se possível. Partindo da premissa de que nada em ciência pode ser inteiramente novo, Hubert afirma que o objetivo da sociologie religieuse é tornar claras ideias obscuras, mal delimitadas, mas, ainda assim, fecundas, usadas pelos pesquisadores. Em suma, a proposta da sociologie religieuse consiste em tratar os fatos religiosos como fatos sociais, isto é, produzidos pela sociedade, onde a ação individual é condicionada pela vida comum, proposta essa que ganhou consciência de si mesma, segundo Hubert, com o advento do primeiro volume do Année: "Mécanisme d'une part, effets produits ou fonction de l'autre, telles seront les bases de l'explication des faits religieux" (HUBERT, 1904, p. XXXVIII).

O problema não se resume, no entanto, a questões concernentes à explicação. A própria ideia de religião não é uma ideia clara, tampouco simples de ser tratada, pois o mesmo termo é empregado para designar uma massa confusa e mesmo contraditória de fenômenos, variando de acordo com a posição social ou das particularidades de quem a enuncia. Não é possível, argumenta Hubert, falar de religião, no singular, mas apenas de religiões; ainda assim, uma distinção precisa ser realizada, qual seja, entre as chamadas religiões de igreja e as religiões de povos. As religiões de igreja, tais como o budismo, o islamismo e o cristianismo consistem em "systèmes d'institutions, d'actes et de pensées qui paraissent à peu près définis et consciemment ordonnés", ou seja, "ce sont des doctrines, comprenant des croyances et des règles d'action, admises par des sociétés qui se qualifient par l'adhésion de leurs membres à ces doctrines" (HUBERT, 1904, p. XXI). Definidas como dogmas, essas doutrinas consistem no credo comum dos membros de uma sociedade religiosa e "son caractère essentiel et nécessaire est d'être l'œuvre d'une église" (HUBERT, 1901e, p. 276). Já as religiões de povos, como as religiões grega e romana, são “des systèmes fort lâches, fort vagues et dont l'unité, pour réelle qu'elle soit, est toute théorique", quer dizer, não há nenhuma unificação real entre os cultos, as fratrias, confrarias e famílias que compõem a religião grega e, quando há alguma 
unificação, esta é meramente administrativa, como na religião romana (HUBERT, 1904, p. XXI). Falar em religião, portanto, envolve uma inevitável confusão linguística.

Longe de conseguir remediar a situação, a solução encontrada é deslocar o problema da religião, procurando saber quais são os fatos religiosos essenciais e quais são as relações que os fatos religiosos mantêm com outras séries de fenômenos nãoreligiosos. É preciso, então, proceder ao mapeamento dos diversos tipos de fenômenos religiosos e das relações que eles mantém com outros fenômenos sociais, para elaborar uma definição provisória de fenômeno religioso que designe precisamente toda essa classe de fenômenos. Por conseguinte, Hubert (1904, p. XXIV) apresenta o que seriam os quatro principais grupos de fenômenos religiosos, espelhando a distinção elaborada para as subseções do Année, que são as seguintes: 1) os movimentos ou atos, tais como os ritos, sejam eles manuais ou orais; 2) as representações, tais como as noções de deus e demônio, de puro e impuro, os mitos e dogmas, bem como da noção de sagrado; 3 ) os fatos de morfologia, isto é, da formação de grupos humanos pelo exercício da vida religiosa, do regime e da hierarquia desses grupos; 4) os fatos de composição, isto é, os sistemas de ritos e de representações, tais como cultos, religiões, doutrinas etc. No entanto, apesar dessa caracterização formal das principais classes de fenômenos religiosos, o foco de Hubert está em apresentar quais seriam aquelas características que dizem respeito à especificidade desse grupo de fatos sociais. Nesse intento, a primeira característica a destacar é que os fenômenos religiosos são fenômenos coletivos, isto é, que a atividade religiosa diz respeito a tudo o que é constante e congruente entre indivíduos associados; mais do que isso, eles se apresentam como verdadeiras instituições, quer dizer, modos de organização fixados por regras que subsistem a despeito e independentemente do acordo individual. Em uma palavra, a respeito dos fatos religiosos, "il s'agit toujours d'éducation, de tradition, de suggestion" (HUBERT, 1904, p. XXVII). Mas há, ainda, uma característica singular dos fatos religiosos, a saber: "des états de foules", característicos de diversas epidemias religiosas, de misticismos contagiosos e de conversões de massas ao longo da história (HUBERT, 1904, p. XXIX). Conforme pondera Hubert, esses estados intensos de superexcitação da força social em comunhão seriam a forma por excelência dos fenômenos religiosos.

Entre essas representações especificamente religiosas, Hubert discute duas que lhe parecem principais e que mantêm uma relação direta entre si, a saber, as noções de 
qualidade e de sagrado. A noção de qualidade se exprime no pensamento primitivo pela personalização de determinadas qualidades, que se distinguem e se transformam em almas, espíritos animados ou mesmo deuses; vivem em espaços-tempo indeterminados e se repetem infinitamente. Com efeito, cria-se um verdadeiro mundo de seres e de qualidades, "où l'imagination dépasse librement les limites de la perception [...] En un mot, le monde de la religion est un monde où la pensée s'objective et où les désirs forts sont immédiatement exaucés" (HubERT, 1904, p. XLIII). Nesse mundo mítico, de qualidades ideais, em que a capacidade de ação individual é reduzida ao mínimo e o coletivo se apresenta como um poder autônomo, suas capacidades se exprimem por meio da arte e do sonho, em que a primeira exprime o "travail esthétique" da expressão religiosa e o segundo exprime, por sua vez, o "pouvoir efficace" das forças religiosas, condicionadas por seus ritos (HUBERT, 1904, p. XLIV). Como afirma categoricamente, "les phénomènes religieux ne sont pas indépendants des phénomènes esthétiques et intellectuels" (HUBERT, 1907c, p. 327). Com efeito, na introdução à seção de sociologie esthétique do Année em 1902, Hubert já havia apresentado seu insight acerca do papel capital da arte na conformação das ideias coletivas elementares:

Dans une théorie générale des représentations collectives, l'art devrait sans doute occuper une place capitale; il fournirait des types de toutes celles qui sont synthétiques et suggestives ; il est évident aussi qu'on pourrait y analyser particulièrement bien les éléments sensibles et affectifs des représentations (HuBERT, 1902f, p. 577; grifo nosso).

De acordo com o autor, as representações coletivas são, primordialmente, imagens estéticas que combinam os elementos sensíveis e afetivos de maneira sintética. Conforme sugere em outra resenha do mesmo volume, os mitos religiosos seriam o melhor exemplo desse tipo de síntese entre formas artísticas de expressão da força sagrada, uma vez que "les impressions synthétiques, les images s'imposent avec une puissance affective et probante" (HUBERT, 1902g, p. 588). Todas essas imagens, noções de ser e de qualidade das crenças e práticas religiosas são determinadas pela noção de sagrado, termo romano utilizado para designar essa representação religiosa por excelência. O sagrado, define Hubert, "est le séparé, l'interdit ; les choses sacrées sont protégées par des interdictions rituelles ; elles sont tabouées" (HUBERT, 1904, p. XLVI). Tal definição estabelece um vínculo explícito entre sagrado e a noção de interdição, em que o sagrado pode ser definido como algo passível de uma interdição ritual, separado 
por uma barreira do que é profano. Sendo o sagrado a ideia matriz da religião, Hubert estabelece sua célebre definição, qual seja: "La religion est l'administration du sacré" (1904, p. XLVII). Mais do que uma ideia, o sagrado é uma ideia de um meio onde se entra e sai por meio de ritos de entrada e de saída, como os ritos sacrificiais. Dessa maneira, temos o tempo sagrado, o espaço sagrado, meios em que essa qualidade resulta em uma força afetiva pela ação dos ritos. O sagrado configura, portanto, muito mais que uma simples noção: Hubert se diz tentado a considerá-la uma categoria, já que é o sagrado que fundamenta a crença religiosa e ela é para as representações religiosas o que as categorias de tempo, espaço e causa são para as representações individuais. $O$ sagrado consiste, nas palavras de Hubert, em uma daquelas "constructions intellectuelles qui sont l'œuvre d'hommes en groupes, comme la classification, comme l'idée de mana, comme celle même de temps", ou seja, "des éléments de la mentalité collective dont nous avons jusqu'à présent étudié la formation" (HUBERT, 1907b, p. 314). Em suma, o sagrado é "la pensée de l'homme en société" (HuBERT, 1904, p. XLVII).

Por fim, Hubert trata dos dramas rituais com especial atenção às cerimônias de iniciação australianas. Segundo o autor, essas cerimônias consistem em ritos dramáticos $^{3}$ que performam os atos míticos a eles associados. Durante a iniciação, o iniciado ganha uma nova alma a partir do manuseio da churinga, objeto que serve de veículo do poder sagrado dos ancestrais (HUBERT, 1902a, p. 405-406). Dessa maneira, "l'initiation est un drame rituel qui figure sa mise à mort et sa résurrection" (HUBERT, 1904, p. XXXII). Esse processo em que o iniciado se torna um novo homem, isto é, adquire uma nova alma pelo contato com o poder mágico durante a cerimônia de iniciação, pode ser traduzido teoricamente da seguinte maneira: a condição religiosa do indivíduo resulta da possessão de uma ou mais almas impessoais. Para além da crítica que essa conclusão apresenta em relação às teorias animistas, cumpre destacar a ênfase na dramatização ritual, na qual "des états d'extase ou de possession qui marquent les crises de l'activité religieuse" significam, precisamente, a "dissolution des consciences individuelles dans une sorte de conscience sociale" que é, para Hubert, inseparável da religião (HUBERT, 1904, p. XXXIV). Não obstante, a dimensão dramática dos rituais religiosos era observada por Hubert não somente entre os australianos. Em uma resenha

3 Na resenha de Hubert e Mauss (1900, p. 211-212) sobre o mesmo livro, os autores já haviam chamado a atenção para a figuração dramática dos atos míticos dos seres totêmicos. 
publicada no ano seguinte, Hubert chama a atenção para a origem religiosa do mimo grego, considerado o germe dos mais variados gêneros dramáticos, do canto à dança, e até mesmo do teatro de Shakespeare (HUBERT, 1905c, p. 630). Segundo o autor, o protótipo do mimo poderia ser encontrado em uma determinada performance dramática comum a diversas sociedades:

les prototypes du mime grec sont des danses où la démarche et les cris de certaines espèces d'animaux étaient imites par un danseur isolé ou un groupe de danseurs. Le mime est d'ailleurs resté fidèle au souvenir de ses origines ; l'imitation des animaux est l'un des traits les plus persistants des spectacles mimiques. De pareilles danses nous sont signalées un peu partout, dans les corroborées australiennes, les cérémonies des sociétés secrètes de l'Amérique du Nord ou de la Polynésie, les spectacles populaires du Japon. [...] Le développement des représentations qui s'attachent aux fêtes amène la spécialisation des rôles. Les plus anciens mimes grecs ont été sans doute, eux aussi, des drames magico-religieux [...]

Le même phénomène s'est produit chez les paysans de l'Europe du Nord. M. Ch. nous décrit, avec une véritable érudition, les fêtes agraires qui tombent aux dates critiques de la vie agricole. Ces fêtes comportent des représentations d'abord rudimentaires, où des groupes de lutteurs et de danseurs figurent les génies, puis plus compliquées, avec des processions de personnages individualisés et de véritables scènes. [...] Les fêtes du printemps comportaient un sacrifice du génie de la végétation, fin de consécration nouvelle et de rajeunissement ; ce sacrifice, figuré dramatiquement, devient un meurtre suivi de résurrection ; [...] Le point où la pièce perd toute espèce de caractère religieux est fort difficile à marquer. De même qu'en Grèce la tragédie et la comédie sont associées aux fêtes de Dionysos, à Rome, à la fête des Floralia, qui est une fête agraire, ont été particulièrement associées les représentations mimiques. [...] Nous pensons donc que le drame mimique a ses racines dans de fort anciennes manifestations d'activité collective qui ne peuvent pas encore être classées dans l'une ou l'autre des espèces de phénomènes sociaux (HUBERT, 1905c, p. 631-632; grifo nosso).

Conforme o trecho acima, Hubert localiza a origem do mimo nas danças e gritos que mimetizam determinados traços dos animais. Esses ritos miméticos seriam característicos dos dramas mágico-religiosos das mais diversas sociedades, como o totemismo australiano, que Mauss estava investigando na época, onde fenômenos estéticos e religiosos se encontram em "état embryonnaire" e "les fonctions ne sont pas encore différenciées" (HUBERT, 1904, p. XL). De maneira semelhante às cerimônias australianas, os ritos miméticos são observados nas festas agrárias greco-romanas, e esse nexo entre estética e religião se mantém até a celebração da primavera dos camponeses do norte europeu, que performam o drama sacrificial de morte e 
ressurreição dos gênios da vegetação por meio de danças e cantos que mimetizam esses espíritos do campo. De acordo com a tendência evolucionária estabelecida por Hubert, portanto, os ritos miméticos têm origem nos dramas sagrados e coletivos das sociedades elementares e mantêm essa fusão estética e religiosa até sua consequente segmentação na performance individual e secular do mimo estritamente estético.

\subsection{As festas sazonais e a conformação do tempo sagrado}

No ano letivo de 1904-1905, Hubert ministrou na EPHE um curso sobre as divisões elementares do tempo entre os povos germânicos. Intitulado "L'année germanique" (HuBERT, 1905b, p. 51), o objetivo era realizar uma análise crítica dos documentos relativos à formação do calendário germânico e investigar os sistemas de divisão por estações mais utilizados. Ao final do mesmo ano, é publicado o "Étude sommaire de la représentation du temps dans la religion et la magie", que condensa suas teses mais gerais sobre o tema. No ensaio, Hubert pretende apresentar uma resolução para a antinomia da fragmentação teórica do tempo e da infinitude e imutabilidade do sagrado. Essa antinomia já havia sido formulada por ele em 1902, em uma introdução à subseção do Année sobre o ritual e sua relação com o calendário, na qual sustenta que ao ritual cabe "mettre en œuvre des représentations et des figurations de l'espace et du temps propres à résoudre cette antinomie" (HUBERT, 1902d, p. 248). No ensaio, Hubert diz que agrupou "les anomalies que présente, en général, le décompte du temps dans la religion.", investigando como os calendários, que se orientam por essa noção religiosa de tempo, comportam determinadas particularidades que escapam à nossa ideia abstrata de tempo, qual seja, "l'idée d'une grandeur continue, indéfiniment divisible em parties successives, homogènes et impénétrables" (HuBERT, 1905a, p. 2). E, de fato, desde o volume 4 do Année havia uma subseção dedicada exclusivamente a resenhar e analisar trabalhos sobre o calendário religioso, na qual Hubert organizou e analisou trabalhos que desembocaram em seu ensaio preliminar sobre a representação do tempo. Em uma dessas resenhas, ainda em 1901, Hubert apresenta os princípios que o fizeram considerar o estudo dos calendários e que, de certa forma, prefiguram seu ensaio sobre a representação mágico-religiosa do tempo. Eis o insight sobre a relação entre o tempo mágico-religioso e o calendário que permitiu a Hubert compreender o tempo como uma ideia coletiva: 
Le temps est un objet de représentations collectives au même titre que l'espace. Il s'ensuit que, d'une part, les catégories sociales, entre autres la notion de sacré, s'appliquent au temps comme à l'espace, et, d'autre part, que les phénomènes naturels qui servent à mesurer la fuite du temps doivent être constatés, choisis et consacrés par l'autorité sociale ou religieuse. Le calendrier détermine les périodes et les qualifie au point de vue social. Il se forme d'abord par un processus de spécialisation qui concentre sur certains moments de la durée les qualités de la durée totale, par exemple un certain degré de caractère sacré. La spécialisation est compensée par la périodicité, périodicité des jours fériés, périodicité des jours néfastes ; la similitude des parties élémentaires du temps est remplacée par la similitude relative de divisions plus longues, mois, années, etc., dont les éléments se succèdent dans le même ordre (HUBERT, 1901c, p. 234).

Em primeiro lugar, Hubert demonstra como o tempo condiciona tanto as práticas quanto as ideias religiosas. Os atos ou os ritos mágico-religiosos variam em função do tempo, estando comumente associados a datas fixas ou a uma ocorrência regular. Já as representações, como os mitos, pensados sob o desígnio do tempo, constituem uma préhistória da humanidade em que os deuses e outras entidades são os seres originários das famílias humanas. Por essa razão, as festas são figurações dramáticas que rememoram episódios dessas sociedades: "Les combats rituels des fêtes populaires deviennent des figurations dramatiques de combats historiques, souvenirs des invasions arabes et normandes en Sicile, arabes et anglaises en France" (HUBERT, 1905a, p. 5). Com efeito, tanto os ritos quanto os mitos possuem uma relação ao mesmo tempo semiabstrata e semiconcreta com o tempo, na medida em que não se relacionam nem diretamente com as durações concretas dos eventos que ocorrem, tampouco com as simples representações puramente abstratas de tempo: estão, assim, "situés dans un tempsmilieu, relativement abstrait et détaché des choses qui durent. [...] Représentation semiconcrète, elle conserve le souvenir des durées réelles" (HUBERT, 1905a, p. 6). Contrariando a noção comum de calendário, usualmente tido como um sistema de mensuração do tempo, Hubert pretende demonstrar que ritos e mitos possuem uma relação mais qualitativa que quantitativa com o tempo pois, para a religião e para a magia, "le calendrier n'a pas pour objet de mesurer, mais de rythmer le temps" (HUBERT, 1905a, p. 7; grifo nosso). Isso se torna mais claro ao introduzir outra noção que interage com as divisões do calendário religioso, a saber, a de datas críticas, que compreende todo momento que é objeto de uma consideração especial, como as festas, bem como os termos extremos das seções de um calendário. Pertencentes ao tempo- 
meio, as datas críticas "brisent les durées concrètes [...] avec une sorte de nécessité ; à plus forte raison brisent-elles la durée abstraite, dont elles font partie" (HUBERT, 1905a, p. 10).

A partir da relação entre o calendário e as datas críticas, Hubert apresenta aquelas que seriam as cinco regras operatórias que caracterizam a noção de tempo-meio, que encadeiam-se e depreendem-se umas das outras, a saber: 1) "Les dates critiques interrompent la continuité du temps" (HUBERT, 1905a, p. 9), dividindo-o em partes heterogêneas e descontínuas, seja pelo acontecimento de festas, seja pelo fim de um ciclo; 2) "Les intervalles compris entre deux dates critiques associées sont, chacun pour soi, continus et insécables" (HUBERT, 1905a, p. 11), quer dizer, os intervalos entre as interdições de duas datas críticas são dotados de uma continuidade e assumem, em toda sua extensão, a personalidade ou qualidade dessas datas críticas; 3) "Les dates critiques sont équivalentes aux intervalles quelles limitent" (HUBERT, 1905a, p. 14), pois quando um ato se realiza em algum momento do período convencionado pelas interdições, ele o preenche e o contamina por completo, tornando a data crítica e o período por ele limitado homogêneos e equivalentes; 4) "Les parties semblables sont équivalentes" (HUBERT, 1905a, p. 16), tendo em vista que as partes que ocupam a mesma posição no calendário, mesmo que as durações sejam de tamanho diferente, são tomadas como unidades simetricamente semelhantes de tempo, como a semana, o mês, a estação, o ano e um ciclo de anos podem ser considerados semelhantes entre si perante essa perspectiva; 5) "Des durées quantitativement inégales sont égalisées et réciproquement" (HUBERT, 1905a, p. 18), seja pela expressão de durações indeterminadas por números precisos, seja pela equivalência mítica entre unidades de tempo muito díspares, ou mesmo por partes que sejam numericamente correspondentes, mas de grandezas diferentes. Dessa maneira, enquanto as três primeiras propriedades são caracterizadas por Isambert (1979, p. 195) como regras de corte, isto é, que constituem a data crítica junto com seu intervalo, as duas últimas seriam as regras de equivalência ou de mensuração do tempo mágico-religioso. Tomando todas tanto em suas propriedades intrínsecas como em suas relações recíprocas, chegamos à seguinte definição: para a magia e para a religião, "les parties successives du temps ne sont pas homogènes", e tampouco "les parties qui nous paraissent égales en grandeur ne sont pas nécessairement égales, ni même équivalentes", ao passo que "sont homogènes et équivalentes les 
parties considérées comme semblables en raison de leur place dans le calendrier" (HubERT, 1905a, p. 8). Essa é, portanto, a caracterização mais precisa das propriedades que constituem a noção mágico-religiosa de tempo-meio.

Resulta daí que o tempo não é uma quantidade pura, homogênea e precisamente mensurável, em que as grandezas são definidas unicamente por sua dimensão e sua posição relativa. No tempo mágico-religioso, considerações de qualidade entram em cena, como os tabus do tempo, que determinam a entrada e a saída das datas críticas e seus intervalos, de tal maneira que o tempo e suas partes são concebidos como dotados de qualidades. Nessa noção de tempo, as unidades de tempo conformam "les unités d'un rythme, où l'alternance des diversités ramène périodiquement au semblable" (Hubert, 1905a, p. 19; grifo nosso). Sendo, portanto, a representação do tempo qualitativo fundamentalmente rítmica, Hubert argumenta que essa noção de ritmo é, por sua vez, o símbolo por excelência da ação coletiva, tão marcada quanto mais extensa e intensa seja a colaboração social. No tempo qualitativo, a associação simpática entre as datas críticas e seus efeitos são convencionadas, isto é, não resultam de experiências objetivas do mundo, mas antes "d'expériences subjectives de la collectivité" (HUBERT, 1905a, p. 30). Para ocorrer, a associação simpática entre as datas críticas e seus efeitos depende da ação do poder mágico-religioso, do mana ou do sagrado, pois "[1]e rythme du temps ne cesse point d'être marqué par la religion” (HUBERT, 1901a, p. 186).

Abstraídas suas associações especiais, por trás das qualidades distintivas do tempo e suas partes encontramos o sagrado como a qualidade comum que dá sentido e fundamenta a noção religiosa de tempo. Assim como as cerimônias sagradas, as datas críticas e suas durações são objeto de ritos de entrada e de saída, como as festas religiosas e outros períodos passíveis de ritos positivos e interdições especiais, até interdições mais gerais que ocorrem periodicamente sobre o tempo, como o sabá termo designado para as datas críticas das religiões semitas, mas que expressa uma relação mais geral, presente em diversas outras sociedades, entre a interdição pela presença do sagrado e alteração da duração temporal. Com efeito, as datas críticas compartilham do mesmo caráter que o sagrado, pois "[1]e propre des choses sacrées est d'être entourées d'interdictions" (HuBERT, 1905a, p. 32). Dessa maneira, tanto as partes do tempo quanto as coisas religiosas que ocorrem são sagradas, na medida em que o 
calendário estabelece as condições nas quais o sagrado se atrela ao tempo e se torna suscetível às diversas transformações. Conforme Hubert:

Mais, en retrouvant la notion de sacré à la racine des représentations qualitatives enregistrées par ce tableau, nous sommes arrivés à une forte présomption, fondée sur la conclusion de notre précédent mémoire, que les conditions émotionnelles et logiques, dans lesquelles a pu se développer, en magie et en religion, la notion de temps sont fort différentes de celles où elle semble devoir apparaître normalement chez les individus. [...] Il faut tenir compte, en effet, de ces états d'agitation collective où nous supposions naguère que s'était formée la notion du sacré. [...] Ces émotions primitives, exceptionnelles et momentanées, ont laissé derrière elles un résidu de croyance, qui renouvelle ou entretient certains de leurs effets, quand la cause en est atténuée. Elles se perpétuent et continuent à conditionner la pensée par la force logique des catégories et des concepts (HUBERT, 1905a, p. 34-35; grifo nosso).

Portanto, a noção de sagrado produzida pelos estados de excitação coletiva das festas periódicas está na base da experiência subjetiva da coletividade na noção de tempo mágico-religioso. Ao temporalizar o sagrado, constitui-se uma cadeia ininterrupta de eternidades cujos ritos poderiam dispersar-se permanecendo idênticos: eis a resolução de Hubert para a antinomia entre a variabilidade do tempo e a invariabilidade do sagrado. Considerando que a divisão do tempo presente nos calendários é uma convenção, que carrega o traço de arbitrariedade coletiva, percebemos que a origem dos calendários é mágico-religiosa. Concebido para prever determinados fatos que demandavam determinados ritos, os calendários foram instituídos em vistas de assegurar essa concomitância. Conforme sintetiza Hubert em uma resenha posterior, os calendários têm por função justamente equacionar as convenções e as durações concretas do tempo por meio do ritmo instituído pelas durações sagradas:

Périodicité du sacré discontinu, pérennité de la société qui prend conscience d'ellemême dans le temps, voilà deux principes cardinaux de la construction des systèmes chronologiques. [...] Mais l'histoire du calendrier est une de celles qui prouvent clairement que la vie sociale ne peut pas se passer dans le domaine de l'illusion sans limite, qu'on ne répond pas à des besoins sociaux par des conventions pures. Il faut que la convention s'objective ou s'appuie sur des objets. Tous les systèmes de chronologie poursuivent le temps vrai. Repères extérieurs, coïncidences effectives, durées réelles, expérience et observation continuelle, voilà ce qu'ils nous présentent. La convention et l'approximation y figurent finalement comme moyens de saisir l'insaisissable (HUBERT, 1913, p. 270). 
Em suma, "le calendrier est l'ordre de la périodicité des rites", "le code des qualités du temps" (HUBERT, 1905a, p. 38-39), ao passo que o trabalho de abstração do qual surgiu a noção de tempo objetivo, quantitativo e abstrato não é senão a decorrência da noção de tempo subjetivo, qualitativo e semiconcreto. Temos, na elaboração de Hubert, aquilo que Watts Miller (2000, p. 6) chamou de tempo sagrado, o tempo que encadeia em suas ações e representações o ritmo da vida coletiva em torno de sua experiência com o sagrado.

Nos anos subsequentes, Hubert continuou a ministrar uma série de cursos sobre les fêtes saisonnières das nações germânicas e celtas que cobrem toda a região da Europa Ocidental. Nos cursos de 1905 a 1907, ele privilegiou a dimensão teórica das festas, enfocando "l'explication des représentations mythologiques qui se développent dans le drame de fête" (HuBERT, 1907d, p. 47). Nos cursos seguintes, Hubert passou a se interessar pela acomodação das datas críticas germânicas e celtas no calendário gregoriano, ilustradas pelas celebrações que marcam o início do inverno: como a Festa de San Martin de 11 de novembro, que remonta as grandes festas sagradas germânicas; e a Festa dos Mortos de 2 de novembro, considerada uma sobrevivência do samhain celta. Nesse sentido, ao observar a popularidade de Saint-Martin como padroeiro de diversas províncias alemãs e francesas, Hubert constata que essas festas de padroeiros católicos se acomodam justamente nas mesmas datas críticas das religiões primitivas europeias (HUBERT, 1908, p. 52). Em seu último curso sobre o assunto, Hubert inicia a investigação sobre a origem das festas de solstício de verão nas celebrações romanas da Fors Fortuna. Celebradas em 24 de junho, elas estariam na origem das festas de SaintJean, que ainda mantém uma série de ritos dramáticos em torno do fogo para celebrar o solstício. Com essa série de comparações, Hubert almejava elaborar "l'étude générale des fêtes" (HUBERT, 1910, p. 120) - projeto que, no entanto, jamais foi concluído. A despeito disso, conforme a resenha de Mauss sobre o ensaio, ao investigar as causas dessa noção de tempo sagrado, Hubert teve o mérito de esboçar os traços gerais da grande lei que assegura não só a vida religiosa, mas toda a vida social, a saber, "la loi du rythme collectif, de l'activité rythmée pour être sociale" (MAUSS, 1907d, p. 305). Nesse sentido, ainda que Hubert tenha mais sugerido que analisado essa lei, Mauss questiona a investigação unilateral do tempo sagrado, pois perderia de vista "l'opposition qui semble régner entre tes moments sacrés, et la durée laïque", ou seja, "entre le temps 
commun, les fêtes et ces dates qui semblent surgir de la sainteté substantielle et éternelle pour découper en tranches diverses la vie courante" (MAUSS, 1907d, p. 304). Com efeito, Mauss sugere deslocar a investigação da constituição do tempo sagrado para a oposição entre sagrado e profano expressa no tempo, aprofundando o conhecimento da chamada lei do ritmo coletivo, conforme realizado em seu estudo das variações sazonais esquimó.

\subsection{Da mitologia heroica à literatura épica}

Nos anos subsequentes até a eclosão da Primeira Guerra, Hubert profere uma nova série de cursos na EPHE, intitulados "Religion et mythologie des Celtes insulaires", dedicados a investigar na religião celta a origem das epopeias e romances gaélicos e britânicos. Os cursos desdobraram até a análise da mitologia épica irlandesa, em que Hubert propôs investigar a relação entre o culto desses seres sagrados individuais e o sistema de festas sazonais: "Le développement du culte des héros en Irlande et de la légende héroïque tient à la structure même de la société irlandaise. On a spécialement insisté sur le rapport du culte des héros et du système des fêtes" (HUBERT, 1914a, p. 94). No mesmo ano, vem a público seu último trabalho do período, o artigo "Le culte des héros et ses conditions sociales". Inicialmente, o artigo seria publicado como prefácio do livro Le culte des héros et ses conditions sociales: Saint Patrick héros national de l'Irlande, de Stefan Czarnowski, seu aluno na EPHE; no entanto, a edição do livro atrasou e foi publicado somente em $1919^{4}$.

O primeiro problema oriundo da leitura do trabalho de Czarnowski é a função que a noção de herói possui para determinadas estruturas da sociedade, enunciado no seguinte axioma: "La notion de héros fait pendant à la notion de chef. Les sociétés à héros sont des sociétés à chefs. Toute société qui a des chefs, si elle ne se définit pas normalement par eux, peut passer par des crises où elle se reconnaît en eux et les héroïse" (HUBERT, 1914b, p. 15). Com efeito, as sociedades que se caracterizam por filiação e chefia são as mais afeitas à formação de heróis. Os sentimentos que os unem em torno de um herói são da natureza do parentesco: parafraseando Durkheim, quando instituições exprimem o princípio da sua união por meio de emblemas, como brasões, bandeiras ou mesmo

4 Talvez por essa razão, o longo prefácio de Hubert tenha sido publicado em 1914 em duas partes na Revue de l'histoire des religions. O artigo omite apenas a primeira seção do prefácio contido no livro, além de pequenas alterações de estilo. 
heróis, “l'emblème crée la parenté entre les hommes réunis. La possession d'un emblème commun prouve la parenté, parce qu'elle la constitue" (HUBERT, 1914b, p. 17). A esse respeito, Hubert reconhece as semelhanças entre a organização social heroica e a totêmica, tendo em vista que ambas se baseiam na organização por clãs. No entanto, embora exista a figura do herói entre os Arunta da Austrália e entre os Pueblos da América do Norte, Hubert é cético quanto à possibilidade de o totemismo estar na origem do culto heroico e, consequentemente, da formação dos clãs heroicos pelos clãs totêmicos: no caso específico dos celtas europeus, principalmente pela falta de dados que esclareçam essas semelhanças, "il est difficile de conclure que le culte celtique des héros se soit élevé sur une base de cultes totémiques" (HUBERT, 1915, p. 246). Tal hipótese de uma origem totêmica dos celtas era aventada há muito por Salomon Reinach, de tal maneira que Hubert já havia criticado a falta de dados para sustentar a pretensa universalidade do totemismo e a consequente interpretação de Reinach sobre o caso celta (HUBERT, 1902b, p. 214). Dessa maneira, Hubert salienta a especificidade da relação entre a noção de herói e as instituições político-domésticas de determinadas sociedades, como é o caso da mitologia romana do rei-herói Romulus e a sua função na formação do reino de Roma. Nesse sentido, o trabalho de Czarnowski sublinhou as relações existentes entre "les héros et les structures sociales, entre la hiérarchie des héros et la hiérarchie de ces structures" (HUBERT, 1914b, p. 20).

Outra questão que se desdobra da monografia de Czarnowski é a relação entre os heróis e a morte ou, mais precisamente, o problema da necessária representação da morte do herói como vítima de um sacrifício. Ao observar a íntima relação entre os heróis e as festas funerárias, Hubert acredita que a reunião de elementos que constituem a morte do herói a tornariam um morto poderoso ou um morto mana, na medida em que essa modalidade de morte "contient-elle en substance tout ce que développe celle du héros" (HuBERT, 1915, p. 229). Entretanto, esse poder não advém do ato de morrer em si, que apenas conserva o poder previamente adquirido em vida pelo herói e o mantém em sua atividade póstuma - o que o diferencia dos demais mortos. Conforme comenta em uma resenha anterior, tal relação entre o culto dos mortos e os heróis era particularmente relevante na Antiguidade grega:

Au culte des morts, se rattachait, en Grèce, le culte des héros. Les héros étaient des morts illustres, non plus des morts anonymes ou des parents. Ils gardaient leur personnalité dans l'au delà, avaient plus de pouvoirs que les autres, provoquaient 
plus d'hommages, plus de requêtes et jouissaient d'une considération, qui n'était pas limitée au cercle étroit d'une famille ou d'une confrérie. Les héros étaient de véritables dieux, mais dont le culte était attaché à un tombeau ou à un lieu considéré comme tel (HUBERT, 1906, p. 285).

Essa situação impõe levar em consideração a própria noção de morte que, longe de ser clara, apresenta variantes cuja afinidade com a representação do herói permite-nos compreender melhor ambas. Retomando o artigo de Robert Hertz (1907) sobre a representação coletiva da morte, Hubert afirma que em nenhum lugar a morte é representada como uma partida brusca e definitiva: pelo contrário, a vida não se desprende imediatamente do cadáver, tanto que comumente concebeu-se essa situação como "un état passager de demi-mort, qui dure ou peut durer tant que n'est pas achevée la décomposition cadavérique. A ce premier stade de la mort correspond une première série de rites funéraires, veillée funèbre, sépulture provisoire, etc" (HUBERT, 1915, p. 233). A condição dos heróis é assimilada a esse estado intermediário entre a vida e a morte, comum a todos os mortos, mas prolongado indefinidamente. Nesse sentido, a morte é muito mais um adjetivo da condição de herói que sua causa determinante, uma qualidade que aparece como um sacrifício exemplar, violento e excepcional. Portanto, não seria a morte, mas antes seu caráter lendário que exprime a natureza da representação coletiva do herói: é o mito que faz o herói, na medida em que são "des symboles de fonctions et de caractères sociaux, qui rendent témoignage jusqu'à la mort" (HUBERT, 1915, p. 243).

Assim como o totem, o herói é o símbolo de uma sociedade definida e confere uma personalidade aos clãs, tribos ou nações. Apesar de não ser deus, o herói também possui algo de sagrado, de religioso, ainda que em menor grau: se manifestam onde a vida religiosa ainda não se separou completamente da vida social, mas cuja especialização do exercício da religião separa os deuses e santos de outras manifestações sagradas mais temporais e seculares, como os heróis gregos e os tautha irlandeses ${ }^{5}$. Ainda assim, as lendas heroicas possuem estreita relação com o universo religioso, pois, tal como os mitos divinos, as lendas heroicas também se dirigem à prática de certos rituais que cruzam, a uma só vez, ideias e práticas, como o caso do sacrifício, que cumpre o papel de exaltar e distinguir a personalidade legendária do herói (HUBERT, 1915, p. 200). Sendo assim, o sacrifício é, por assim dizer, o ritual típico e mesmo essencial do

5 Cf. a resenha de Hubert (1901d) sobre a mitologia irlandesa e a literatura inglesa. 
processo de heroização: "Son déroulement solennel, ses lentes préparations, son action réglée, son appareil théatral en font un drame où peut se développer un caractère de héros" (HuBERT, 1915, p. 202). Mas não é tudo: além disso, os sacrifícios levados em consideração no estudo de Czarnowski ocorrem em circunstâncias determinadas, nas festas, permitindo ao pesquisador analisar tanto a gênese quanto o funcionamento da lenda heroica no meio ritual correspondente. A festa implica a uma só vez tempo e ritual, mais especificamente o tempo sagrado e um ritual público e positivo, mais complexo, solene e importante que outros rituais ordinários, pois engaja uma pluralidade maior de atores. Como avaliara Hubert em uma resenha, cumpre designar “[1']importance relative des actes d'une fête tient donc à des raisons d'ordre esthétique et non à des considérations pratiques" (HUBERT, 1903a, p. 198). Ao mesmo tempo, a festa possui uma data e é, inclusive, uma data crítica: "Une date de fête est un élément du temps, qui se distingue des autres par des qualités particulières de telle nature que le sacré peut s'y produire au milieu du profane" (HUBERT, 1915, p. 220). Sendo assim, as datas críticas em conjunto formam sistemas homólogos, em que as festas são tomadas como equivalentes e, ao se repetirem, reproduzem um mesmo fato mítico - no caso, uma mesma lenda heroica.

Dessa maneira, todas as considerações sobre o sacrifício e as festas sugerem uma relação entre o herói e o drama ritual que ele encerra. Enquanto, para uns, o herói seria responsável por criar o drama em torno de si, Hubert pensa precisamente o contrário, isto é, que o drama sagrado seria o responsável por produzir o herói:

entre le drame et le héros [...] nous donne à penser, de l'autre côté, que celui-ci s'est pour ainsi dire formé dans le drame. Le drame le précède. C'est une représentation, impliquée par une fête, de faits naturels et surnaturels, dont les éléments, les moments, les images antithétiques prennent une expression vivante et personnelle sous les espèces des héros. Bon nombre de ces héros paraissent tout devoir au drame festival, leur nom, leur état-civil, leur attitude et leur caractère. Tous lui devraient en moins quelque chose de leur nature et de leur vitalité héroïque, car, même dans ces drames primitifs, l'action dramatique, le jeu des caractères, l'incarnation du type par l'acteur ont pu contribuer à donner au personnage ou à développer chez lui cette personnalité morale dont on a voulu faire le caractère distinctif des héros. C'est une personnalité théatrale (HUBERT, 1915, p. 214-215; grifo nosso).

Conforme Hubert, o drama sagrado das festas públicas periódicas é responsável por conformar o caráter moral do herói, considerado, por essa mesma razão, uma 
personalidade teatral. Apesar da eficácia inerente aos ritos, o drama do herói reduz à quase pura representação: representa-se não para algum objetivo, mas pelo representar em si mesmo. Como dramatis persona, o processo de heroização terminou no desenvolvimento do drama secular: "Dans cette évolution de la représentation dramatique et de la fête, le héros, être religieux, s'est donc rapproché jusqu'à le rejoindre du héros littéraire" (HUBERT, 1915, p. 224). Essa investigação sobre a evolução dos mitos religiosos aos contos já era objeto de investigação de Hubert desde o início do Année, de modo que em 1902 ela passou a ter uma subseção própria de obras a serem resenhadas sob essa rubrica. Na introdução à nova subseção, Hubert apresenta a dinâmica de depuração dos elementos formais do mito que estariam presentes nos contos, subtraído o elemento de crença que caracteriza os mitos religiosos:

Les recueils groupés sous cette rubrique contiennent des contes proprement dits ; l'élément croyance en a disparu à mesure que leur caractère esthétique se déterminait. Si les prototypes ont eu un caractère religieux, mythique, leurs dérivés sont laïcisés et ne nous intéressent plus ici que par réflexion. Les procédés d'esprit qui ont fixé la forme du mythe se retrouvent avec plus de clarté dans les contes ; la transformation lente du mythe en conte fait partie de l'histoire du mythe; enfin, les contes ont été à leur tour une source de croyances ; c'est ce dont témoigne l'histoire de la magie, une partie des mythes de celle-ci lui ayant été libéralement fournis par le roman merveilleux. D'autre part, s'ils ne sont pas objets de croyance, les contes impliquent des croyances ou des représentations du surnaturel qui s'imposent avec une autorité variable à la croyance ; c'est ce qui les fait retourner au mythe. [...] Leurs acteurs sont impersonnels [...] Lorsqu'à ces figures vagues se substituent des héros historiques ou mythiques, sans d'ailleurs que la substance du récit en soit changée, il me semble préférable de réserver aux nouveaux produits le nom de légende. La détermination des acteurs déplace entièrement l'intérêt de l'action. L'aspect aussi en est changé. C'est une autre espèce esthétique qui a une évolution propre (HUBERT, 1902e, p. 293-294).

Temos, então, mais um caso da origem religiosa de fenômenos não-religiosos, expressa na representação literária do mito do herói dissociado de sua origem religiosa. Ainda assim, cumpre a Hubert enfatizar o lastro religioso permanente nos mitos, mesmo dos heróis, lastro este que se constitui, justamente, como a necessidade do exercício da imaginação; mas uma imaginação que precede toda atividade positiva e fornece-lhe objetos. Nesse sentido, Hubert sustenta que a religião não é um jogo de livre criação mas, antes, um princípio de ação: "Image lumineuse qui surgit d'obscures réflexions, elle est un pôle d'attraction pour les pensées flottantes et les sentiments confus; elle est aussi un principe d'action" (HUBERT, 1915, p. 225). 
Em resumo, os heróis são uma formação mitológica de certa complexidade, produto da imaginação coletiva, caracterizada pelo tanto pelo elemento negativo, isto é, funerário, quanto pelo elemento positivo, que se reporta ao caráter épico-dramático dos cultos e lendas heroicas. Para Hubert, importa enfatizar esse elemento positivo, pois "les ressources que les fêtes fournissent à la figuration, l'élan qu'elles donnent à l'imagination et la liberté qu'elles lui laissent sont pour l'élément épique et dramatique des légendes de héros le principe et la condition d'un développement merveilleux" (HUBERT, 1915, p. 244). Portanto, a relação entre sacrifício, festa e morte conformam o elemento dramático e figurativo do caráter da mitologia heroica que, segundo o autor, permite-nos estabelecer as condições para investigar o desenvolvimento das lendas heroicas de seu contexto religioso até sua autonomização estética na literatura, tendo em vista que a "persistance de ces cadres mentaux est un des phénomènes capitaux de l'histoire de la pensée collective" (HUBERT, 1903b, p. 276).

\subsection{Conclusão}

Ao analisarmos os textos de Hubert que tratam dos fenômenos religiosos, pudemos observar como o autor deu continuidade à abordagem da sociologie religieuse, sublinhando a relação entre religião e estética como constitutiva das ideias e práticas coletivas elementares. A partir da análise do desenvolvimento das religiões primitivas no continente europeu, Hubert foi responsável pelo desenvolvimento da lei do ritmo da vida coletiva, que encadeia os tempos sagrado e profano a partir da alternância entre as festas sazonais e a vida profana. Segundo o autor, as festas sazonais são datas críticas que interrompem a vida ordinária e estabelecem um tempo qualitativo e extraordinário, dedicado à performance dramática e aos consequentes estados de êxtase coletivos que caracterizam a criação e manipulação do poder sagrado. Assim, a alternância entre os dramas sagrados conforma unidades de ritmo que produzem, por sua vez, os calendários, considerados uma forma elementar de mensuração e de predição do tempo. Além disso, Hubert se dedicou à análise da origem da mitologia heroica nos dramas sagrados elementares, estabelecendo uma análise evolucionária dos dramas desde a origem sagrada até a sua segmentação estética na literatura épica. Considerando a relevância da arte para conformação das ideias e práticas religiosas, Hubert observa que o drama sagrado constitui igualmente o culto dos heróis. Todavia, devido ao processo de 
secularização, a dissociação da unidade mito e rito e a consequente perda do caráter sagrado resultou na depuração dos elementos estéticos da mitologia heroica na forma da literatura épica. Em ambos os casos, portanto, Hubert deu continuidade à teoria do sagrado, enfatizando os elementos estéticos e intelectuais da ação ritual, bem como a sua capacidade de transfigurar as forças sociais em ação.

Ao acompanharmos o percurso realizado por Hubert durante esse período, pudemos observar o desenvolvimento da sociologie religieuse nos distintos planos de análise. Quanto ao seu objeto de estudo, Hubert privilegiou a análise crítica da documentação arqueológica e histórica dos povos europeus, desde os Celtas e os Germânicos, passando pelos Gregos e Romanos da Antiguidade até a consolidação do Catolicismo na Idade Média. Do ponto de vista metodológico, vimos que o autor se dedicou especialmente à explicação genética, analisando as transformações dos mitos e ritos ao longo do tempo, sem perder de vista o papel desempenhado pelos fenômenos religiosos dentro de seu contexto de investigação. Do ponto de vista teórico, Hubert explicitou a relação entre religião e estética na análise das suas formas elementares. A esse respeito, as ideias religiosas são consideradas representações figuradas, ou seja, imagens estéticas que sintetizam elementos intelectuais e afetivos, cujo melhor exemplo são os mitos. Os ritos, por sua vez, consistem em performances dramáticas de certos aspectos dos seres e eventos míticos. Tomados em conjunto, a unidade formada entre mito e rito caracteriza os dramas sagrados periódicos, que definem o ritmo da vida coletiva por organizar tanto os ciclos de plantio e colheita quanto o culto das personalidades mágico-religiosas. Nesse sentido, ainda que inacabada, a teoria geral das festas sazonais de Hubert identificou a centralidade do culto aos gênios do campo no contexto dos povos indígenas europeus e a consequente transformação dessas crenças e práticas até a conformação das festas dedicadas às personalidades míticas sagradas como os santos e heróis. Por um lado, tal processo evolucionário remonta sua análise da origem dos deuses a partir dos sacrifícios agrários do capítulo anterior; por outro, Hubert identifica, na tendencia à formação mitológica de heróis, o ideal de hierarquia como um traço característico da morfologia e do pensamento indo-europeu. Do ponto de vista evolucionário, Hubert concebe a dinâmica da vida coletiva a partir da alternância cíclica entre concentração e dispersão do sagrado, determinada pelas festas sazonais. Por fim, o decurso da evolução religiosa é marcado pela tendência de dissociação entre os mitos e 
ritos e da consequente secularização das ideias e práticas estéticas até a sua transformação em literatura e teatro. Para Hubert, portanto, importa não somente identificar as formas religiosas elementares mas observar suas transformações ao longo do tempo. 


\section{Capítulo 4. \\ Mauss e o desenvolvimento da sociologie religieuse: a lógica da ação ritual e suas transformações}

O presente capítulo dá continuidade à investigação da contribuição de Marcel Mauss para a análise sociológica dos fenômenos religiosos, tomando por referência o período de desenvolvimento subsequente dessa abordagem por Mauss enquanto editor da seção sociologie religieuse do Année sociologique. Tal período compreende a desde a publicação, em colaboração com Hubert, de "Introduction à l'analyse de quelques phénomènes religieux" (1908), a tese inacabada, La prière (1909), seguida de artigos e comunicações das pesquisas em andamento até a eclosão da Primeira Guerra. A seleção dos trabalhos analisados corresponde a todas as publicações de Mauss durante o período citado que tratam dos fenômenos religiosos, incluindo artigos, cursos e resenhas. Nesse sentido, nossa análise sublinha a extensão do escopo da sociologie religieuse por Mauss durante esse período, notadamente desde sua tese sobre a origem da prece nos rituais australianos até o estudo comparado das prestações coletivas nas norte-americanas e melanésias. Conforme pretendemos demonstrar, Mauss não apenas continua a explorar as potencialidades estéticas e intelectuais da ação ritual, mas estabelece a centralidade desse tipo de ação coletiva para além do domínio estritamente religioso, considerando como o modelo elementar de ação social.

O capítulo está subdividido em cinco partes. Na primeira, apresentamos um balanço crítico realizado por Mauss acerca de algumas das contribuições seminais da sociologie religieuse, sublinhando que a unidade dessa abordagem consiste em tratar ideias e práticas religiosas elementares como formas de conhecimento e de expressão estética. A segunda parte concentra-se em investigar a introdução geral da tese sobre a prece, enfatizando como o autor define as manifestações elementares da prece e como estas esclarecem as tendências de desenvolvimento dos fenômenos religiosos modernos. A terceira parte trata da estratégia mobilizada por Mauss para investigar os ritos orais elementares das cerimônias religiosas arunta, além de avaliar o escopo dos capítulos inacabados e o alcance dos argumentos parcialmente desenvolvidos. Já a quarta parte 
analisa uma miscelânea de comunicações e cursos que revelam o crescente interesse de Mauss em instituições elementares como o potlatch, em que podemos entrever as suas primeiras hipóteses acerca dos sistemas de prestações religiosas, jurídicas e econômicas. Por fim, a última parte é dedicada a realizar uma síntese da análise empreendida e seus resultados, destacando a centralidade de ação ritual para a abordagem desenvolvida pela sociologie religieuse.

\subsection{Fenômenos religiosos como juízos de valor e expressões estéticas}

Em 1908, Mauss publica dois trabalhos que intentam avaliar a abordagem desenvolvida pela sociologie religieuse ao longo dos anos anteriores, a saber: o último da série de escritos em colaboração com Hubert, "Introduction à l'analyse de quelques phénomènes religieux", publicado na Revue de l'histoire des religions; e a longa resenha "L'art et le mythe d'après M. Wundt", publicada na Revue philosophique de la France et de l'étranger. O primeiro artigo foi concebido como introdução para o livro publicado no ano seguinte, Mélanges d'histoire des religions (1909), que consiste numa coletânea de alguns dos frutos da colaboração entre Hubert e Mauss². Tomados em conjunto, os dois trabalhos mantém o costumeiro tom crítico às teorias concorrentes, rebatendo críticas e sustentando tanto a abordagem quanto os resultados alcançados pela sociologie religieuse nos temas tratados. Nesse sentido, importa-nos demonstrar que esses trabalhos "ne laissent pas de se lier à un plan et d'être dominés par un certain nombre d'idées qui en font l'unité" (HuBERT; MAUSS, 1908, p. 163).

O primeiro tópico concerne ao estudo realizado pelos autores sobre o sacrifício. A abordagem concorrente, de Robertson Smith, propunha uma explicação genealógica do sacrifício, que, por sua vez, tinha como fenômeno de origem a refeição comunal do animal totêmico praticada por certos grupos semitas. Além disso, para o autor, o "totem

1 Não é possível identificar com clareza a divisão do trabalho na redação do artigo. Nas poucas cartas a respeito, Hubert propõe elaborar um primeiro rascunho e enviar para Mauss, que ficaria responsável por desenvolver as explicações e enviar ao editor. De acordo com uma carta de 1908, sabemos que Durkheim (1998, p. 389-390) leu e reagiu negativamente ao artigo, sem entrar em detalhes, alegando apenas que ele mesmo estava escrevendo uma obra que tratava de vários dos problemas presentes na introdução. Como será visto adiante, o provável motivo para a desaprovação de Durkheim diz respeito à exposição de discordâncias teóricas internas à equipe do Année.

2 A coletânea foi produzida com vistas à primeira e malsucedida candidatura de Mauss a uma cadeira do Collège de France (FOURNIER, 1994, p. 312-317). Nela constam, além da introdução, mais três artigos: "Essai sur la nature et la fonction du sacrifice" (1899); o artigo "L'origine des pouvoirs magiques dans les sociétés australiennes", de Mauss; e "Étude sommaire de la représentation du temps dans la religion et la magie", de Hubert. 
sacrifié c'était, et cela dès l'origine, le dieu sacrifié, puisque le totem, pour les hommes d'un clan, fait fonction de dieu" (Hubert; MAuss, 1908, p. 173). De acordo com Hubert e Mauss, tal genealogia é factualmente equivocada, uma vez que o sacrifício só é observado em contextos não totêmicos e, portanto, não é possível estabelecer relações de causa e efeito entre fenômenos jamais associados. Mesmo nas descobertas mais recentes da existência de sacramentos totêmicos entre os Arunta - em que há comensalidade do totem pelo clã -, Hubert e Mauss observam a falta do que eles consideram ser o elemento definidor do sacrifício, a saber: a oblação ou a oferta da coisa sacrificada à divindade. Conforme concluem: "Dans le sacrement totémique le plus complet qui ait été observé chez les Arunta, on ne voit pas le mécanisme entier du sacrifice" (HuBERT; MAUSS, 1908, p. 167). Sendo assim, a única exceção à regra foi observada entre os Zuñi, notadamente "celui des daims pratique par la confrérie des chasseurs" (HUBERT; MAUSS, 1908, p. 169). Nesse caso, há tanto o sacramento do totem como o seu sacrifício, que é oferecido a uma divindade do panteão zuñi. No entanto, "un pareil sacrifice, qui est unique, est un fruit récent de leur histoire religieuse" e, portanto, nada tem de primitivo (HUBERT; MAUSS, 1908, p. 172). Da mesma maneira, o caso zuñi prova, contra Smith, que "le sacrifice du dieu n'était ni au début des religions ni au début même du sacrifice, mais qu'il s'était développé après le sacrifice au dieu et, à partir d'un certain moment, parallèlement à lui" (HUBERT; MAUSS, 1908, p. 173). Do ponto de vista genético, o rito sacrificial seria um produto tardio da evolução religiosa, porque: i) apresenta um mecanismo demasiado complexo, oriundo da conjunção de ritos de sistemas religiosos anteriores; ii) depende que as coisas sagradas sejam definitivamente separadas e representadas sob a forma de personalidades espirituais divinas. No totemismo, ao contrário, ainda não há divindade constituída, tampouco o animal ou planta totêmicos servem como intermediários ou vítimas para consagração. É por essa razão que "le sacrifice pleinement constitue ne nous parait pas compatible avec tous les degrés du totémisme" (HUBERT; MAUSS, 1908, p. 177).

Ao contrário de Smith, Hubert e Mauss compararam os textos sagrados hindus e judaicos com o objetivo de depreender o mecanismo e a eficácia do rito sacrificial. Por meio do estudo da unidade entre mito e rito, os autores argumentam que são reveladas tanto a crença ligada ao mito quanto a eficácia esperada do rito; mais especificamente, as comemorações dramáticas durante as festas revelam "les sentiments nombreux et 
forts qui se jouent dans les sacrifices" (HUBERT; MAUSS, 1908, p. 165). Por um lado, o estudo visava mostrar como o rito sacrificial era uma forma social de ação, mesmo quando praticada por indivíduos, pois é a sociedade que determina a vítima e dispõe dos meios de consagração, bem como nomeia e convoca os deuses. Dessa maneira, a crença na eficácia do rito é determinada pela forma social do ato, isto é, pela forma ritual: "Si on croit au sacrifice, s'il est efficace, c'est qu'il est un acte social" (HUBERT; MAUSS, 1908, p. 178). Por outro lado, esses ritos estão investidos de uma mesma qualidade, a de serem sagrados. Mais do que dizer que as coisas sagradas são coisas sociais, para Hubert e Mauss importa mostrar, antes, que "est conçu comme sacré tout ce qui, pour le groupe et ses membres, qualifie la société" (HUBERT; MAUSS, 1908, p. 178). Conforme concluem os autores:

Elle [le sacré] est bien sans doute l'idée-force autour de laquelle ont pu s'agencer les rites et les mythes. Elle se présentait dès lors à nos yeux comme étant le phénomène central parmi tous les phénomènes religieux. Nous nous sommes proposé pour tâche de comprendre cette notion et de vérifier ce que nous avions dit sur l'identité du sacré et du social. Nous avons pensé que le but ultime de nos recherches associées, devait être l'étude de la notion de sacré (HUBERT; MAUSS, 1908, p. 179; grifo nosso).

Assim, ao concluírem que o sacrifício é rito manual de comunicação do domínio profano com o sagrado por intermédio de uma vítima, Hubert e Mauss acabaram por encontrar na noção de sagrado a ideia-força que agencia os ritos e mitos religiosos em geral, responsável pelos sentimentos religiosos intensos propiciados pelas celebrações religiosas dramáticas. Não obstante, o sagrado não só qualifica tudo aquilo que é religioso, mas se identifica logicamente com tudo o que é social. Conforme Mauss define em um de seus cursos, os fenômenos religiosos nas sociedades elementares compreendem "la totalité des phénomènes sociaux où intervient la notion de forces sui generis dans une société" (MAUSS, 1907e, p. 37). Tal identidade entre sagrado e sociedade permitiu, portanto, a criação de uma abordagem sociológica alternativa àquelas individualistas e intelectualistas predominantes em história e antropologia das religiões.

Da mesma maneira, para a escola antropológica britânica, a magia constituía um caso ainda mais incontestavelmente individual e oposto ao domínio religioso. Mesmo 
para um simpatizante da sociologia durkheimiana, o jurista Paul Huvelin ${ }^{3}$, o fenômeno mágico era tido como um fenômeno social anômalo. Para Huvelin, apesar da magia apresentar ritos tão eficazes quanto os do sacrifício, "il leur manque l'adhésion formelle de la société", na medida em que "ni ces mythes, ni ces représentations abstraites dont la valeur pratique est si haute, ne sont explicitement l'objet de l'accord unanime et nécessaire d'une société" (HUBERT; MAUSS, 1908, p. 179-180). Em artigo publicado no Année no ano anterior, "Magie et droit individuel" (1907), Huvelin questionava como a magia pode ser, ao mesmo tempo, obrigatória e ilícita, religiosa e antirreligiosa. Para superar essa contradição, Huvelin designa um conjunto distinto de sanções e ritos mágicos na Roma antiga que estariam na origem do direito individual e constituiriam, para ele, a fonte única dos contratos. Hubert e Mauss, por sua vez, respondem à crítica de Huvelin, argumentando que boa parte do mal-entendido tem a ver com o emprego equivocado do adjetivo mágico para designar a mesma força presente tanto nos rituais públicos mágicos quanto nos religiosos. Ao adotar uma definição de senso comum como cientificamente válida, "Huvelin n'a pas répudié ce vice de la nomenclature et c'est pourquoi il fait de la magie la source unique des contrats" (HUBERT; MAUSS, 1908, p. 186). Consequentemente, o erro de nomenclatura levou Huvelin a chamar de mágicas sanções e ritos que pertenciam ao sistema da religião, e não ao da magia. Conforme Hubert e Mauss contra-argumentam, o domínio dos fenômenos religiosos compreende tanto o sistema formado pela religião quanto o sistema da magia e, portanto, os fenômenos mágicos são fenômenos religiosos que "ne fait pas partie des cultes organisés" (HuBERT; MAUSS, 1908, p. 186). Dessa maneira, os fenômenos mágicos são sociais sem serem obrigatórios, precisamente porque a obrigação não é, para Hubert e Mauss, uma característica distintiva dos fenômenos sociais:

Enfin, sans être obligatoires, les rites de la magie sont néanmoins sociaux. L'obligation proprement dite n'est pas pour nous le caractère distinctif des choses, des actes et des sentiments sociaux. L'acte magique illicite reste pour nous social, sans qu'il y ait là contradiction. L'acte est social parce qu'il tient sa forme de la société et qu'il n'a de raison d'être que par rapport à elle. [...] Au surplus la magie n'est pas nécessairement illicite et, dans le droit, en fait, elle sert aussi bien au droit public qu'au droit individuel. Ainsi, dans les tribus australiennes les menaces d'envoûtement sont pour les vieillards un moyen de faire respecter la discipline (HUBERT; MAUSS, 1908, p. 186-187; grifo nosso).

3 Para uma análise da relação de Huvelin com a sociologia durkheimiana, cf. Roger Cotterrell (2005). 
De maneira resumida, Hubert e Mauss mostram como a magia, sendo parte do domínio religioso, serve tanto ao direito individual quanto ao direito público, a exemplo das ameaças de encantamento para manutenção da coesão social nas tribos australianas. Isso porque, no estudo dos fenômenos religiosos, os mitos e os ritos se tornaram os verdadeiros signos para a observação de crenças e práticas coletivas. O rito mágico é social porque retira a sua forma da sociedade: isto é, porque a forma de execução de um ato mágico, para que possa ser definido como rito e seja eficaz, é necessariamente coletiva. Portanto, o abandono da obrigação em favor dos ritos e mitos como signo dos fenômenos sociais permitiu a Hubert e Mauss explicar a magia como um fenômeno social.

Ainda que o duplo caráter sagrado e social dos ritos e crenças mágicas não seja visível à primeira vista, ele não deixa de estar presente. A tradição que o mágico observa é justamente o que garante "l'efficace des gestes et de l'autorité des idées”, pois “qui dit tradition dit société” (HUBERT; MAUSS, 1908, p. 181). Mesmo os mágicos isolados estão ligados por tradições mágicas e corporações que garantem a transmissão e a eficácia dos ritos. Tomando a magia como uma instituição social, foi possível determinar o quanto, “dans la magie, l'individu ne pense, n'agit que dirigé par la tradition, ou poussé par une suggestion collective" (HuBERT; MAUSS, 1908, p. 187-188). Dessa maneira, "le magicien est un fonctionnaire de la société, souvent institué par elle, et qui ne trouve jamais en lui-même la source de son propre pouvoir" (HUBERT; MAUSS, 1908, p. 180). Esses poderes conferidos pela sociedade ao mágico possuem todos uma mesma qualidade e procedem de uma mesma ideia geral, o mana, que fundamenta tanto as práticas e ideias da magia quanto da religião. Respondendo à crítica de Jevons sobre a universalidade dessa ideia-força mágico-religiosa, Hubert e Mauss argumentam que esse princípio existe em diversas outras sociedades, designado por outros nomes. Isso implica que o fenômeno social pode existir até mesmo na falta de um substantivo para designá-lo, pois “n’est pas indispensable qu'un phénomène social arrive à son expression verbale pour qu'il soit" (HUBERT; MAUSS, 1908, p. 183). A esse respeito, os autores relembram que os Gregos, bem como os Hindus, não possuíam um termo em grego ou em sânscrito que correspondesse ao latim sacer e, no entanto, "les Grecs et les Hindoux n'ont-ils pas eu une conscience très juste et très forte du sacré?" (HUBERT; MAUSS, 1908, p. 183). Com efeito, a noção polinésia de mana é uma dentre as demais 
expressões verbais nativas que designam o conjunto de ideias, sentimentos e forças mágico-religiosas que estão por trás tanto da magia quanto do sacrifício:

Il en résulte que les rites et les représentations magiques ont le même caractère social que le sacrifice et qu'ils dépendent d'une notion identique ou analogue à la notion de sacré. De plus, nous avons commencé à montrer qu'il y a des cérémonies magiques où se produisent des états collectifs de nature à engendrer cette notion de mana (HUBERT; MAUSS, 1908, p. 181; grifo nosso).

Conforme os trabalhos anteriores de Hubert e Mauss haviam demonstrado, a noção de mana tem sua origem naqueles estados de êxtase coletivo engendrados nas cerimônias públicas mágico-religiosas elementares. Análoga à noção de sagrado, a noção de mana é, portanto, o princípio eficaz dos fenômenos mágico-religiosos.

Tanto a natureza das operações intelectuais quanto as categorias envolvidas na magia e na religião eram igualmente objeto de discussão. Os antropólogos britânicos sustentavam que essas operações consistiam em raciocínios por analogia, tais como os de contiguidade e semelhança, interpretados como aplicações equivocadas do princípio de causalidade. Contra essas interpretações, Hubert e Mauss sustentam que as operações mágico-religiosas consistem em juizos de valor, ao mesmo tempo afetivos e racionais, que submetem o sentimento coletivo ao controle da experiência. Tais juízos se fundamentam em valores sociais "derrière lesquelles il y a des sensations, des besoins collectifs, des mouvements des groupes humains" (HUBERT; MAUSS, 1908, p. 194). Reconhecendo a contradição inerente a esses juízos de valor coletivos, Hubert e Mauss argumentam que expressam "des synthèses indispensables où s'équilibrent des sentiments et des sensations également naturels et également contradictoires" (HUBERT; MAUSS, 1908, p. 190). Dessa síntese contraditória, tanto a religião quanto a magia contribuíram para maturação do espírito humano nas mais variadas formas de conhecimento, das técnicas aos mitos. A investigação das categorias mágico-religiosas constitui, portanto, não só uma etapa da evolução religiosa, mas confunde-se com a investigação da evolução das categorias do entendimento humano. No estudo dos fenômenos religiosos, são as categorias de tempo e de espaço aquelas que se ligam mais diretamente à análise dos mitos e dos ritos. Estes têm lugar em condições espaçotemporais sagradas e, com efeito, produzem noções qualitativas de tempo e espaço: “droite et gauche, nord et sud, avant et après, faste et néfaste [...] Mais les temps et les espaces sacrés dans lesquels se réalisent les rites et les mythes sont qualifiés pour les 
recevoir" (HuBERT; MAUSS, 1908, p. 192). Mauss, por exemplo, havia estudado a relação entre o espaço sagrado e as classificações segundo as regiões entre os indígenas norte-americanos; Hubert, por sua vez, se deteve na relação entre o tempo sagrado e as classificações temporais dos povos germânicos, estabelecendo daí como a alternância entre as festas e os períodos profanos contribuiu para formar os primeiros calendários. Com efeito, analisando tais transformações foi possível compreender como a noção de sagrado é "celle en fonction de laquelle les autres se classent, mais aussi se produisent par segmentations et oppositions successives, c'est-à-dire en somme la mère et la génératrice des représentations religieuses" (HUBERT; MAUSS, 1908, p. 193). Do ponto de vista evolucionário, portanto, importa investigar a gênese e o desenvolvimento das sucessivas transformações simbólicas produzidas pelos mitos e ritos em torno da noção de sagrado.

Nesse sentido, o estudo das categorias liga-se ao desenvolvimento das ideias e categorias religiosas. Tomando a noção de mana como uma categoria germinal do pensamento indígena, Hubert e Mauss a reconhecem como "la forme première qu'ont revêtue, d'autres catégories qui fonctionnent toujours dans nos esprits: celles de substance et de cause" (HuBERT; MAUSS, 1908, p. 190). Contra animistas como Wundt, Hubert e Mauss pensam, igualmente, a ideia impessoal e abstrata de mana como germe das representações religiosas pessoais. Segundo os autores, as noções animistas pressupõem uma noção implícita de força, que é produzida durante os rituais e que, no entanto, é independente e anterior à noção de espírito: "Dans la notion d'âme ne sont pas données à la fois les qualités de spirituel et de puissant; au contraire, elles sont données ensemble, par une synthèse naturelle, dans la notion de mana" (HUBERT; MAUSS, 1908, p. 196). Com efeito, é a partir dessa noção impessoal que as representações pessoais são criadas como mana especializado que a sociedade atribui aos indivíduos em razão de seu parentesco, totem ou iniciação - tal como a churinga durante as cerimônias de iniciação arunta. Portanto, a noção de mana constitui a condição lógica e histórica do desenvolvimento tanto de categorias abstratas, como as de causa e de substância, quanto de ideias concretas e pessoais, como as de alma e de deus: "Le fond reste identique, mais la métamorphose n'en est pas moins naturelle et fatale" (HUBERT; MAUSS, 1908, p. 198; grifo nosso). Por essa razão, as categorias e representações religiosas não se resumem a ideias especulativas, como presumem 
alguns críticos; mas são, antes, instituições sociais, às quais os indivíduos aderem por meio da educação. Para a sociologia durkheimiana, o estudo das instituições implica que "les faits de la psychologie sociale et les faits de la morphologie sociale sont liés par des liens intimes et indissolubles" (HuBERT; MAUSS, 1908, p. 199). Tal ligação não significa, porém, “que tous les phénomènes religieux n'aient que des causes morphologiques", ou seja, "que les états mentaux des groupes humains n'aient d'autre origine que les mouvements matériels de la masse sociale" (HUBERT; MAUSS, 1908, p. 199). Se há civilizações cujas variações de organização social implicam em variações concomitantes das formas de culto, como entre os indígenas norte-americanos, também existem aquelas nas quais os princípios religiosos são responsáveis por produzir padrões de organização social, como é o caso dos Hindus e seu sistema de castas. Assim, a sociologie religieuse chega às explicações gerais da vida social por meio do estudo das variações "que présentent les institutions ou les notions de même espèce, suivant les sociétés, que nous définissons, soit les résidus constants que ces variations laissent, soit les fonctions équivalentes que les unes et les autres remplissent" (HUBERT; MAUSS, 1908, p. 201).

Por fim, Hubert e Mauss se engajam na polêmica a respeito da natureza sui generis dos sentimentos religiosos, sustentada pela psicologia da religião de William James e seus seguidores. Para essa corrente, a experiência religiosa estaria fundada em "un sentiment d'ordre spécial, surhumain sacro-saint", uma espécie de experiência mística com deus, cujas religiões positivas "ne seraient que des manifestations maladroites" (HuBERT; MAuss, 1908, p. 201). Hubert e Mauss, por sua vez, reconhecem o papel das emoções nos fenômenos religiosos, mas rejeitam existir qualquer sentimento religioso de natureza sui generis. Para os autores, ao contrário, são sentimentos e emoções ordinários que são mobilizados pelos fenômenos religiosos:

Bien loin de nier le sentiment dans la religion, nous pensons trouver dans les notions de valeur, c'est-à-dire dans les notions sentimentales, l'origine des représentations religieuses et des rites. L'analyse des sentiments complexes qui fondent la notion de sacré et celle des sentiments qu'elle provoque, scrupules, craintes, espoirs, etc., est pour nous, le but dernier de la science des religions. - Ce que nous nions, c'est qu'il y ait dans ces sentiments quoi que ce soit de sui generis. [...] Il n'y a pas de sentiments religieux, mais des sentiments normaux dont la religion, choses, rites, représentations comprises, est produit et objet (HUBERT; MAUSS, 1908, p. 201-202). 
De acordo com Hubert e Mauss, são as noções de valor qualitativas encontradas na origem dos fenômenos religiosos, tais como as noções de mana e sagrado, nada tem de especial. Ao contrário, o que é específico dos fenômenos religiosos é precisamente a maneira de articular os estados emocionais ordinários por meio de crenças e práticas religiosas. Nesse sentido, a abordagem da sociologie religieuse se diferencia por enfatizar a realidade sui generis das instituições religiosas, negando a existência de sentimentos especificamente religiosos. "Ce qui est vrai, c'est que tout phénomène religieux est le produit d'une certaine masse sociale douée d'un certain état d'esprit et animée de certains mouvements" (HuBerT; MAuss, 1908, p. 201). Dessa maneira, como alternativa ao misticismo corrente, a sociologie religieuse se interessa em analisar os meios pelos quais essas emoções são elaboradas e agenciadas.

A esse respeito, no ensaio sobre a obra de Wundt, Mauss argumenta que "l'art et le jeu, dans la société comme dans l'individu, sont des moyens imaginaires de créer des émotions" (MAUSS, 1908b, p. 50; grifo nosso). Nesse sentido, a arte é considerada um fenômeno social, tanto por sua natureza quanto por seus efeitos, capaz não apenas de produzir, mas, principalmente, de compartilhar os mesmos sentimentos numa dada coletividade: "Il est le produit de la fantaisie collective, mais il est aussi ce sur quoi on s'accorde et dont les effets sentimentaux sont relativement les mêmes chez tous à un moment donné, dans une société donnée" (MAUSS, 1908b, p. 58; grifo nosso). Com efeito, Mauss sustenta que a performance dramática tem por função despertar e ritmar a maneira pela qual as emoções afetam a plateia, destacando a capacidade da dança em modular sentimentos por meio da articulação entre movimentos e ideias durante as cerimônias religiosas:

la danse extatique, qui a pour objet [...] provoquer un état d'excitation sensorielle, fantastique, hallucinatoire, [...] nous la croyons d'un grand intérêt ; car on sait le rôle considérable joué par ce procédé dans l'art et dans la religion, mais surtout dans la religion où les mouvements disciplinés et monotones de la danse extatique conduisent aux états recherchés de la possession ou de l'extase proprement dite (MAUSS, 1908b, p. 55; grifo nosso).

Conjugados aos cantos de coral, pinturas corporais e encenações dramáticas, os movimentos repetitivos da dança têm o poder de desencadear estados coletivos de êxtase que são característicos das cerimônias religiosas elementares. Nesse sentido, esses rituais mágico-religiosos elementares constituem fenômenos de estética total, cujo 
poder e criatividade remontam à origem religiosa não só das categorias de entendimento, mas também dos fenômenos estéticos. Tal qual formulada por Mauss, a teoria do drama sagrado se fundamenta nessa relação intrínseca entre religião e estética para compreender a capacidade de transformação de ideias, práticas e sentimentos coletivos.

\subsection{Gênese e evolução da prece}

Em 1909, Mauss imprime uma versão parcial de sua tese, intitulada La prière les origines. De maneira geral, Mauss pretendia investigar a origem e a evolução da prece, tomando as cerimônias mágico-religiosas australianas como caso elementar e, eventualmente, seguindo o desenvolvimento da prece no hinduísmo e no cristianismo primitivo. Apesar de jamais tê-la concluído, sabemos que Mauss trabalhou ativamente no manuscrito entre 1907 e $1908^{4}$ (FOURNIER, 1994, p. 333-336). No entanto, o início da redação da tese é bem anterior: em 1901-1902 e 1902-1903, Mauss ministrou dois cursos na EPHE cujos problemas tratados correspondem em grande medida àqueles presentes no manuscrito de 1909. A única parte finalizada da tese, o Livro I, compreende o estudo “des formes élémentaires de la prière. - Recherche d'une définition du rite religieux en général et de la prière em particulier" (MAUSS, 1902e, p. 29). Nesse sentido, a proposta do Livro I consiste em criticar os trabalhos e a abordagem vigente na área de ciência das religiões, demonstrando como a aplicação do método genético pode revelar, ainda que de maneira preliminar, algo sobre a evolução da prece e, ao mesmo tempo, a relevância desse fenômeno para compreender a evolução religiosa em geral. Se, por um lado, a discussão metodológica da tese segue de perto aquela desenvolvida nos trabalhados publicados entre 1901 e 1904; por outro, Mauss esclarece como o estudo sociológico de um fenômeno religioso elementar pode iluminar tendências gerais de desenvolvimento dos fenômenos religiosos modernos.

Em primeiro lugar, Mauss lamenta a pobreza da literatura científica em contraste com a abundante literatura ideológica sobre a prece. Tanto historiadores quanto filólogos da religião eram unânimes em desconsiderar a prece em seus estudos nas civilizações indígenas e antigas, por considerá-la um produto tardio da evolução

4 As razões para a interrupção da tese são, provavelmente, de várias ordens, mas não há uma resposta definitiva para a questão. Segundo Fournier, Mauss trabalhou na redação da tese até a erupção da Primeira Guerra (cf. FOURNIER, 1994, p. 340-341). 
religiosa. Coube, então, à teologia e à filosofia da religião, principalmente em sua vertente protestante e liberal, encabeçar os estudos sobre a prece. Tais pesquisas se baseiam na introspecção como método de investigação, em que, segundo Mauss, o que se estuda não é o fenômeno da prece, mas a ideia preconcebida que os investigadores possuem a respeito da prece. Na versão protestante liberal, a prece se torna um diálogo espiritual direto com deus, tomando-a como fenômeno essencial de toda religião. $\mathrm{Na}$ medida em que é considerada uma manifestação do estado da alma daquele que reza, para esses autores a prece é essencialmente um fenômeno individual e inapreensível a não ser interrogando a si próprio. Contra tais interpretações ${ }^{5}$, Mauss adverte que a observação interior é insuficiente para explicar o fenômeno da prece, precisamente porque sua origem não é encontrada na consciência individual mas, antes, em fatores externos que a escapam. Produto do esforço acumulado dos homens durante as gerações, a prece é "un fragment d'une religion", isto é, "un système organique de notions et de pratiques collectives ayant trait aux êtres sacrés" (MAUSS, 1909a, p. 31). Isso significa que a prece pode ser considerada um fenômeno social tanto pelo conteúdo quanto pela forma: do ponto de vista do conteúdo, a prece é dominada pela ideia de sagrado, uma vez que suas fórmulas são consagradas e que ela só se dirige a seres e coisas sagradas; do ponto de vista da forma, a prece não existe fora da ideia de um ritual, é um discurso ritual, que permanece uma linguagem coletiva mesmo quando performada por indivíduos. Dentre os signos que permitem o reconhecimento do caráter coletivo da prece, Mauss cita o fato de que em muitas religiões ela é dita somente pelo grupo ou pela autoridade sacerdotal. Assim, entre os hindus, os brâmanes são "les hommes du brahman, du mot sacré" (MAUSS, 1909a, p. 33), e somente estes estão autorizados a rezar; entre os judeus, ainda que não exista uma proibição relativa à oração individual, as únicas orações que temos transcritas consistem em cânticos ou salmos entoados publicamente pelos chantres ou pelo povo reunido. Mesmo se considerarmos o momento em que ainda não havia qualquer interdição estabelecida contra a oração individual, veremos que "au principe nous ne trouvons que des prières collectives, ou à forme rigoureusement collective" (MAUSs, 1909a, p. 36). Os indígenas

5 É o caso da tese de Segond sobre a psicologia da prece: apesar de incluir informações importantes sobre comunidades cristãs místicas, acaba por aderir ao vocabulário místico e introspectivo; conforme conclui Mauss em sua resenha, "à la théorie de la prière comme phénomène religieux et social, M. Segond n'apporte aucune contribution” (MAUSs, 1913c, p. 239). 
australianos, por exemplo, recitam cânticos durante determinadas cerimônias, com vistas de "assurer la reproduction des espèces animales dont elles se nourrissent" (MAUSS, 1909, p. 38). Com efeito, entender a prece como parte integrante de um ritual significa compreendê-la como uma instituição social, que articula tanto "le caractère créateur des formes" quanto as forças sagradas "que la société impose" (MAUSS, 1909a, p. 37).

Tratar a prece como uma instituição permite, segundo Mauss, perceber o caráter das coisas religiosas e sociais que por muitas vezes foi desprezado, qual seja: de como "une même réalité peut revêtir de multiples formes tout en restant elle-même et sans changer de nature" (MAUSS, 1909a, p. 3-4). Tal caráter de transmutação dos fenômenos religiosos se estenderia também à prece, na medida em que esta última partilha ao mesmo tempo da natureza das crenças e das práticas religiosas: é um rito, na medida em que é um ato dirigido a coisas sagradas e que se espera dele um resultado; mas é também um credo e possui um sentido como um mito, pois exprime ideias e sentimentos religiosos. Contra aqueles que pretendem descobrir o princípio religioso seja nos mitos ou nos ritos, Mauss sustenta que a prece também constitui um caso em que ação e pensamento estão indissociavelmente ligados e que a solidariedade entre as ordens mítica e ritual se torna evidente como "les deux faces d'un seul et même acte" (MAuss, 1909a, p. 7). Dessa maneira, Mauss concebe a prece como uma linguagem que articula ação, ideias e sentimentos religiosos:

La prière est une parole. Or le langage est un mouvement qui a un but et un effet ; il est toujours, au fond, un instrument d'action. Mais il agit en exprimant des idées, des sentiments que les mots traduisent au dehors et substantifient. Parler, c'est à la fois agir et penser : voilà pourquoi la prière ressortit à la fois a la croyance et au culte (MAUSS, 1909a, p. 5).

Por articular as crenças e práticas religiosas de uma só vez, a prece é um signo particularmente útil para analisar o desenvolvimento das religiões ao longo do tempo. Por um lado, boa parte dos ritos se encontra em contínua decadência: boa parte dar interdições alimentares praticamente desapareceu, assim como o sacrifício subsiste apenas sob a forma mítica nas religiões mundiais. Por outro lado, o oposto parece ocorrer com a prece: apesar de ser fenômeno relativamente marginal nas religiões elementares, adquiriu cada vez mais protagonismo a ponto de representar praticamente a totalidade da vida religiosa no protestantismo liberal. Por essa razão, ao acompanhar a 
evolução da prece poderíamos ter acesso à evolução da própria vida religiosa. Conforme uma resenha de 1899, autores como Cornelis Petrus Tiele sustentavam que a evolução religiosa acompanhava a da civilização: ou seja, assim como a autoridade moral perde seu caráter exterior e se interioriza, da mesma maneira "le développement religieux, comme le développement social, a pour but l'harmonie librement consentie des individus" (MAUSS, 1899c, p. 189-190). Mauss não discorda dessa tendência, mas a complexifica, sustentando que a evolução da vida religiosa seria caracterizada por uma dupla tendência, não só individualização, mas também de espiritualização:

la religion a subi une double évolution. - D'abord elle est devenue de plus en plus spirituelle. Tandis qu'elle consiste, dans le principe, en rites mécaniques, matériels et précis, en croyances étroitement formulées et faites presque exclusivement d'images sensibles, elle a tendu, dans son histoire, à faire de plus en plus grande la place de la conscience. Les rites sont devenus des attitudes de l'âme plutôt que des attitudes du corps, ils se sont enrichis d'éléments mentaux, de sentiments et d'idées. Les croyances de leur côté s'intellectualisent et, de moins en moins matérielles et détaillées, se réduisent à un nombre de jours plus petit de dogmes au sens a la fois riche et variable. - En même temps qu'elle se spiritualise la religion tend de plus en plus à s'individualiser. Les rites commencent par être surtout collectifs ; ils ne sont guère accomplis qu'en commun, par le groupe rassemblé. La plupart des croyances n'existent d'abord que sous une forme traditionnelle ; [...] elles étaient répandues dans toute la collectivité avec une uniformité dont nous pouvons difficilement nous représenter la rigueur. L'activité des individus en matière de notions et d'actes religieux s'exerçait alors dans les limites les plus étroites. L'évolution a renversé la proportion, et c'est, à la fin, l'activité du groupe qui se trouve limitée. Les pratiques religieuses sont devenues pour la plupart vraiment individuelles. L'instant, le lieu, les conditions, les formes de tel ou tel acte dépendent de moins en moins de causes sociales. De même que chacun agit presque à sa guise, de même chacun est aussi, dans la mesure du possible, le créateur de sa foi. Même certaines sectes protestantes, les remonstrants par exemple, reconnaissent à tout membre de l'Église une autorité dogmatique. Le "dieu intérieur" des religions les plus avancées est aussi le dieu des individus (MAUSS, 1909a, p. 8-9).

De acordo com Mauss, a evolução da vida religiosa caracteriza-se pelos processos de espiritualização e individualização. As crenças e práticas religiosas que, na origem, eram materiais, externas, e coletivas, tornam-se cada vez mais etéreas, subjetivas e individuais, culminando na ideia do deus interior e individual do protestantismo liberal. Nesse contexto, a evolução da prece acompanha a evolução religiosa e também passa por uma dupla transformação: no início estritamente coletiva, exterior e mecânica, agindo por meio de sons e grunhidos fixados pelo grupo, a prece acabou por se tornar 
mental, interior e subjetiva, baseada em conversações internas e pessoais com deus. Para Mauss, a perenidade da prece se explica por sua natureza oral: enquanto os gestos dos ritos manuais tendem a se modelar de acordo com os efeitos esperados, os ritos orais como a prece seriam mais plásticos que os ritos manuais. Sendo a prece um discurso, foi possível espiritualizar-se e adaptar-se às matizes das diferentes consciências individuais. "C'est ainsi que en même temps qu'elle a profité de l'évolution religieuse", a prece também "a été l'un des meilleurs agents" (MAUSS, 1909a, p. 10).

O estudo da prece como instituição social demanda, então, um método de investigação apropriado para tal fim. A esse respeito, Mauss introduz uma breve digressão no intuito de explicitar os três passos metódicos que considera imprescindíveis para uma pesquisa científica bem-sucedida, a saber: definição, observação e explicação. A definição inicial ou provisória consiste em elaborar uma noção clara e distinta de prece, afastando-se das nomenclaturas baseadas em prenoções subjetivas, confusas e inexatas. Tal definição metódica deve ser construída a partir dos seus caracteres exteriores e aparentes, que permitam reconhecer, agrupar e delimitar o conjunto de fenômenos a ser observado. Já a observação do fenômeno da prece tal qual definido não significa, por sua vez, uma simples descrição de dados imediatos. Visto que o material de análise consiste em um conjunto de documentos históricos e etnográficos, é preciso proceder a uma observação indireta do fenômeno por meio desses documentos: ou seja, mais do que simplesmente localizá-los, é preciso partir dos dados etnográficos para construí-los por meio de uma crítica documental, tendo em vista que não há fatos “qui appellent autant la critique, il n'en est pas auxquels elle soit aussi peu appliquée" (MAUSS, 1909a, p. 45). Assim, a crítica dos documentos etnográficos comporta, em primeiro lugar, a crítica externa, que consiste em "établir le coefficient d'erreur" do documento, "étant donné l'état où il se trouve, la façon dont il nous a été transmis, la date, les sources, etc" (MAUSS, 1909a, p. 45). No caso específico da prece, é preciso levar em conta toda a cadeia de informações, pessoas e contextos que se interpõem entre o sociólogo e o fenômeno a ser observado: a transcrição da prece na língua original, a capacidade de traduzi-la adequadamente e as condições de enunciação da prece - por quem, como e quando a prece foi enunciada - são questões igualmente importantes. Em segundo lugar, “à la critique du document doit s'ajouter la 
critique du fait rapporté dans le document" (MAUSS, 1909a, p. 47). Chamada crítica interna, ela consiste em situar o fenômeno em seu meio social e investigar como esse meio agiu sobre o fenômeno. Sendo assim, aplicando o princípio de interdependência dos fenômenos socais, procura-se a qual período ou sistema ritual determinada prece está ligada, bem como "la signification qu'il a dans son ensemble et dans chacune de ses parties" (MAUSS, 1909a, p. 47). O que interessa é, portanto, saber “quelle collectivité l'a employée, dans quelles conditions, à quel stade de l'évolution religieuse", bem como "la place qu'il occupe dans l'ensemble du rituel" (MAUSS, 1909a, p. 50).

Conduzidas nesse espírito, as críticas externa e interna preparam o caminho para a realização do terceiro passo, a explicação. No caso da prece, o objetivo seria o de “construire une hiérarchie de notions qui s'éclairent mutuellement, et dont l'ensemble constitue une théorie de la prière" (MAUSS, 1909a, p. 51). Para explicar a prece, Mauss prescinde da explicação esquemática, como a empregada no estudo sobre o sacrifício, e advoga em favor da explicação genética: nesse modelo de explicação, parte-se "des formes les plus rudimentaires qu'ait présentées le fait considéré pour passer progressivement aux formes de plus en plus développées, et l'on fait voir comment les secondes sont sorties des premières" (MAUSS, 1909a, p. 52). No intuito de construir uma classificação genealógica dos tipos de prece, é necessário identificar as formas mais rudimentares de prece que se conhece e delas derivar os tipos subsequentes. Entretanto, Mauss esclarece que trabalhar com distinções genéticas entre formas rudimentares e desenvolvidas não implica considerar as primeiras simples e as segundas complexas, pois "les formes les plus rudimentaires ne sont à aucun degré plus simples que les formes les plus développées. Leur complexité est seulement de nature différente"; no caso das formas rudimentares, o que as diferencia é que "[l]es éléments qui se distingueront et se développeront dans la suite de l'évolution y sont rassemblés dans un état de pénétration mutuelle" (MAuss, 1909a, p. 54-55). Com efeito, a classificação genealógica nos faz conhecer "les formes élémentaires" do fenômeno, que "ne disparaissent pas complètement devant les formes les plus élevées, mais elles persistent au-dessous, a coté, ou a l'intérieur même de ces dernières, comme pour témoigner de leur origine" (MAUSS, 1909a, p. 58). Para Mauss, o estudo das formas elementares em sociologia é mais importante e mais urgente, pois estas "sont les causes profondes des faits que nous connaissons" permitindo o estabelecimento de hipóteses 
mais precisas sobre a evolução dos fenômenos religiosos (MAUSS, 1909a, p. 15). Contudo, se a classificação genealógica estabelece um quadro lógico da gênese do fenômeno, ela não nos faz conhecer sua causa. As forças que transformam os fenômenos religiosos são necessariamente exteriores e, por essa razão, deve-se buscar as causas da prece e de sua variação no meio imediatamente dado em que a prece acontece, isto é, no meio social. Sendo assim, a explicação causal da prece consistiria em identificá-la como parte de determinado sistema religioso associado a um dado tipo de sociedade:

dans ces milieux sociaux on peut distinguer en quelque sorte deux sphères concentriques, l'une formée Par l'ensemble des institutions générales de la société, l'autre par l'ensemble des institutions religieuses. [...] Certes, [...] c'est encore le milieu social général qui est le moteur dernier, car c'est lui qui produit dans le milieu religieux les modifications qui se répercutent dans la prière. Il n'en est pas moins vrai que les causes prochaines sont particulièrement religieuses. C'est donc dans ce cercle déterminé des phénomènes sociaux que la comparaison devra le plus généralement se mouvoir (MAUSs, 1909a, p. 59-60; grifo nosso).

De acordo com o modelo delineado por Mauss, todo fenômeno religioso particular está relacionado ao mesmo tempo a dois círculos concêntricos: as instituições religiosas constituem as causas mais próximas e as instituições sociais gerais as causas últimas. Mas os fenômenos, as instituições e o meio social estão em perpétuo devir, de modo que "[1]a succession historique des formes devient donc le facteur important de l'explication" (MAUSS, 1909a, p. 54). Por meio do uso do método comparativo, a explicação genealógica propõe acompanhar as variações concomitantes entre a prece, o meio religioso e o meio social mais amplo para determinar como "certains types de prières sont caractéristiques de telle organisation sociale et inversement" (MAUSS, 1909a, p. 56). A explicação genética da prece consiste, portanto, em procurar tanto a posição quanto as variações do fenômeno em relação aos meios religioso e social.

Para entender os traços fundamentais da evolução da prece, o estudo de sua origem e desenvolvimento deveria compreender ao menos três partes, das quais somente a primeira era objeto da tese de Mauss. A primeira parte seria dedicada às formas religiosas elementares australianas, onde são investigados os germes ou ritos orais "plus riches et plus frustes cependant que celles que nous avons l'habitude d'appeler proprement des prières" (MAUSS, 1909a, p. 11) para compreender, assim, as formas fixas e rudimentares a partir das quais se seguiram suas primeiras transformações. 
Tomando os grupos totêmicos australianos como objeto, Mauss pretende investigar a existência "des prières magico-religieuses destinées à entretenir la vie de certaines espèces animales ou végétales" (MAUSS, 1909a, p. 56). Uma vez constituída a prece tal como a delineamos, a segunda parte teria o objetivo de investigar o processo de espiritualização da prece na Índia antiga. Conforme Mauss sempre insistira, "le rituel védique est certainement parti d'un état qui rappelle celui des plus perfectionnes des rituels polynésiens", tendo se desenvolvido até alcançar as formas de orações estritamente mentais e de "concentration mystique de la pensée" que estão também na origem da meditação ascética budista (MAUSS, 1909a, p. 12). Na teologia brâmane, por exemplo, anna-virâj é uma métrica, composta por três versos de dez sílabas cada, que serve ela mesma de alimento espiritual aos deuses quando entoada repetidamente nos hinos sagrados brâmanes. Com efeito, ao oferecer o alimento místico ao grande deus por meio do canto, o brâmane espera receber em troca os alimentos necessários ao longo do ano: "La répétition d'un vers est une oblation d'aliment aux dieux, et elle est un moyen d'obtenir du ciel les substances nutritives qui en découlent" (MAUSS, 1911b, p. 335-336). Já a terceira parte do estudo teria por objetivo estudar o processo de individualização da prece, tendo como objeto o contexto das religiões semíticas e do cristianismo primitivo. Em uma resenha de 1903, investigando as condições de origem da prece cristã no contexto semita, Mauss afirma que os rituais praticados nos templos eram, sobretudo, manuais, e que a prece só começou a ser prescrita e praticada por leigos com o surgimento da sinagoga: uma congregação popular de rezadores, que praticavam uma prece comum, ritmica e mecânica. É dentro da sinagoga que se propagam os movimentos messiânicos, dentre eles o de Jesus Cristo, cujo papel consistiu em "d'avoir extrait de ce matériel une sorte de schème condensé de la prière, tel qu'il pût servir à la piété indivduelle au lieu d'être réservé, comme l'était enconre la prière synagogale, à l'action efficace de la congrégation ou église réunie" (MAUSS, 1903f, p. 216). No cristianismo primitivo, a prece consistia sumariamente em glorificações, graças e súplicas, moldadas segundo o princípio retórico de uma conversa franca do cristão com deus. Todavia, a expansão e institucionalização da religião cristã ao longo do decurso histórico limitaram a disseminação da prece livre e individual em favor do retorno da prece coletiva e mecânica e fixa. De acordo com o autor:

Cet état est, d'ailleurs, tellement instable que, dès les générations suivantes, par suite de l'établissement du culte chrétien proprement dit, la prière exclusivement 
commune, rythmée, mécanique, recommença à prendre le dessus. Mais il n’y avait là aucun fait de dégénérescence ; cette évolution était inévitable. $\mathrm{Si}$, au sein d'une communauté très resserrée, où les sentiments de sympathie mutuelle atteignaient une intensité exceptionnelle, un nouveau système de prière avait pu se former à côté des systèmes plus anciens, il ne pouvait recevoir son plein et entier développement que beaucoup plus tard et dans des religions dont l'individu, et non pas l'église, était l'agent fondamental, et, par suite, dans des sociétés où l'individualisme était organisé. Voilà pourquoi la semence créée à ce moment, n'arrive à sa véritable floraison que dans certaines formes du protestantisme (MAUSS, 1903f, p. 217).

Mauss ofereceu, nesse trecho, uma espécie de síntese da abordagem da sociologie religeuse no que diz respeito à prece em dois níveis de análise. $\mathrm{O}$ primeiro diz respeito ao nascimento de um novo sistema de crenças e de práticas de oração nos rituais praticados pelas comunidades cristãs primitivas, em que os fiéis experimentavam sentimentos de simpatia mútua de intensidade excepcional. Em resenha anterior, Mauss já havia feito referência a essa "effervescence interne" das comunidades cristãs primitivas (MAUSS, 1899d, p. 270). Nesse sentido, no nível ritual, o drama sagrado performado por essas comunidades produziu verdadeiros estados de eferverscência coletiva, dando origem a um novo conjunto de crenças e práticas religiosas que configura a prece cristã primitiva. Já o segundo nível de análise diz respeito à relação entre esse novo sistema de crenças e práticas e o meio social a ele correspondente. Se o culto cristão primitivo permitiu, no nível das comunidades pequenas e estritas, o advento de novas crenças e práticas, o meio social mais amplo da época não tinha condições de oferecer o mesmo suporte para que esse sistema de prece se generalizasse e se institucionalizasse no decurso da evolução do cristianismo. O sistema de crenças e práticas no qual é a igreja o agente fundamental não havia desaparecido completamente e, no momento seguinte, durante a institucionalização do catolicismo romano e ortodoxo, a prece coletiva, rítmica e mecânica voltou a ser preponderante. Segundo Mauss, somente em uma sociedade na qual o ideal de individualismo já estivesse organizado seria possível o florescimento da prece individual, como aconteceu, de fato, durante o protestantismo. No decurso das formas históricas do cristianismo, Mauss identifica "deux grandes oscilations du mouvement chrétien, qui trop individualiste à l'origine, devient, trop social dans le catholicisme et redevient individualiste avec la reforme" (MAUSS, 1898f, p. 177). Tais transformações são possíveis na medida em que 
"une même forme contient em elle des possibles très divers et même opposés, et suivant ces circonstances, c'est l'une ou l'autre de ces virtualités qui se réalisent" (MAUSS, 1909a, p. 56). Temos, portanto, que as ideias e práticas religiosas são criadas num meio ritual restrito, mas sua efetivação depende de uma relação complexa e dinâmica desses fenômenos religiosos com as demais instituições e a morfologia do meio social mais amplo.

De todos os passos metodológicos previstos para a tese, no entanto, o único efetivamente finalizado foi o primeiro, da definição inicial. Sendo a prece comumente designada como um dos ritos da religião, é preciso esclarecer, primeiro, em que consiste o conjunto de práticas religiosas chamadas de ritos. Remontando a definição de rito mágico, Mauss afirma que o rito é "une action traditionnelle efficace” (MAUSS, 1909a, p. 68), mas de uma eficácia sui generis, não mecânica, oriunda de "forces spéciales que le rite aurait la propriété de mettre en jeu" (MAUSS, 1909a, p. 70). Mas à diferença dos ritos mágicos, cuja eficácia é atribuída a uma força imanente ao próprio rito, os ritos religiosos produzem seus efeitos "par l'intervention de certaines puissances qui sont considérées comme existant en dehors du rite", isto é, por intermédio das "puissances sacrées" e "des êtres religieux auxquels ils s'adressent" (MAUSS, 1909, p. 70-71). Os ritos religiosos são, portanto, “des actes traditionnels efficaces qui portent sur des choses dites sacrées" (MAUSS, 1909a, p. 74). Por conseguinte, a prece apresenta todos os caracteres do rito religioso: ou seja, é igualmente um ato tradicional de eficácia sui generis, que tem por objetivo agir nos seres sagrados. Tal conjunto dos ritos religiosos pode ser subdividido em duas ordens: os i) ritos manuais, que consistem em movimentos corporais e de objetos; e os ii) ritos orais, que nada mais são que locuções rituais. À primeira vista, a prece pertence ao domínio dos ritos orais; ainda que ela tenha se desenvolvido em formas meditativas, a prece continua sendo uma forma de linguagem, mesmo que a palavra não seja pronunciada. Ainda assim, a demarcação dos limites entre os ritos manuais e orais não é unívoca e, em alguns casos, há ritos manuais que cumprem a mesma função dos ritos orais, por consistirem em tipo de linguagem gestual ou dramatúrgica. Conforme Mauss:

il y a certains rites manuels, nettement symboliques que l'on pourrait appeler des prières, parce qu'ils sont en réalité une sorte de langage par geste; par exemple toutes les dramaturgies religieuses, qui ont pour but de reproduire les hauts faits des dieux, leurs luttes contre les démons, etc., sont des pratiques équivalentes aux chants pries qui racontent aux dieux leur propre histoire et les incitent à renouveler 
leurs exploits. Mais elles ne sont que sur la marge de la prière, comme le langage par gestes est sur la marge du langage articulé, et par conséquent, nous ne les retiendrons pas dans notre définition. [...] Leur origine en effet est toujours orale, c'est à la vertu des mots qu'ils doivent leur pouvoir (MAUSS, 1909a, p. 79-80; grifo nosso).

A diferença entre os ritos religiosos orais e manuais seria de grau e não de natureza pois, no limite, ambos consistem em um tipo de linguagem simbólica que varia, dentro um mesmo contínuo, entre gesto e pensamento. Os dramas rituais que têm por objetivo figurar a ação dos seres sagrados seriam homólogos aos cânticos e a outras formas primitivas de rito oral. Ainda assim, a prece seria caracterizada originalmente pela oralidade e pelo domínio das palavras, estando, portanto, a meio caminho entre os ritos estritamente corporais ou meditativos. Dessa maneira, chegamos à seguinte definição inicial: "la prière est un rite religieux, oral, portant directement sur les choses sacrées" (MAUSS, 1909a, p. 81).

\subsection{O intichiuma australiano e os ritos orais elementares}

O Livro II da tese, intitulado "Nature des rites oraux élémentaires", tem como objetivo analisar a origem da prece nas cerimônias religiosas australianas. Apesar de inacabada, seus dois capítulos finalizados dizem respeito ao histórico das fontes e à discussão sobre a existência de preces na Austrália, tópicos que foram trabalhados por Mauss nos cursos sobre as as formas elementares da prece, ministrados em 1901 e 1902 na EPHE. Nesses cursos, Mauss realizara um "[i]nventaire soigneux de tous les faits connus sur les rites oraux des Australiens" (MAUSS, 1902e, p. 29), seguido de "une revision complète et critique des documents publiés jusqu'à ce jour”, que o permitiu estender suas conclusões “à toutes les religions australiennes” (MAUSS, 1903e, p. 99). O terceiro e inacabado capítulo do manuscrito contém uma análise dos ritos orais das cerimônias intichiuma, até onde o material etnográfico disponível permitiu analisar. Tal material compreende, fundamentalmente, as etnografias de Spencer e Gillen sobre as cerimônias intichiuma (1899 e 1904); em suas resenhas, Mauss reconhece essas etnografias como pertinentes no que diz respeito às descrições dos materiais e das práticas gestuais indígenas, mas lamenta o tratamento sumário dado à descrição dos mitos e, principalmente, a falta de transcrição dos cantos entoados nas cerimônias em questão (MAUSS, 1900c, p. 214; MAUSS, 1905b, p. 243). Segundo Mauss, Spencer e 
Gillen estavam mal equipados do ponto de vista linguístico e comunicavam-se com os indígenas apenas por pidgin English, comprometendo a possibilidade de compreensão e descrição de fenômenos filológicos. Mauss procura preencher essa lacuna com o relato etnográfico do missionário alemão Louis Schulze (1891), o único documento a conter a transcrição de alguns ritos orais até então. Tal lacuna só começou a ser preenchida, muito tempo depois, por outro missionário alemão, Carl Strehlow, que iniciou o projeto de transcrição e tradução de mitos, contos e outros elementos da tradição oral dos povos australianos da região. Ao contrário da missão britânica, a missão alemã estava mais ligada à descrição dos fenômenos orais, como os mitos, em detrimento das circunstâncias rituais. Como veremos, esse descompasso entre as etnografias britânicas e alemãs foi o principal fator acadêmico para a descontinuidade da tese de Mauss ${ }^{6}$. Ainda assim, veremos como a estratégia e o rigor de análise etnográfica, bem como as hipóteses formuladas pelo autor tiveram uma fortuna perene na reflexão sobre os rituais australianos.

De acordo com Mauss, as poucas pesquisas anteriores que tratavam da prece primitiva, como as de Edward Taylor e de Max Müller, a classificavam como uma evolução dos encantamentos. Dessa maneira, esses estudos se localizavam na mesma linha de argumento daqueles que derivavam a religião da magia. Mauss atribuía esses e outros equívocos desses autores à falta de rigor para estabelecer as comparações, bem como à falta de seleção de uma instituição religiosa precisa e específica para estudar a questão. Nesse sentido, a escolha das sociedades australianas por Mauss obedece a três critérios: $1^{\circ}$ ) que os ritos orais tenham um caráter religioso, isto é, que digam respeito a coisas sagradas; $2^{\circ}$ ) que esses ritos orais sejam observáveis a ponto de se poder "former une hypothèse sur l'origine de la foi mise en eux"; $3^{\circ}$ ) que não seja possível encontrar, “dans l'état actuel de nos connaissances, de phénomènes plus élémentaires” (MAUSS, 1909a, p. 91). Apesar de não serem realmente primitivas, as sociedades australianas seriam elementares pois permitiam "représenter schématiquement, tout en supposant derrière elles une longue histoire, les premiers groupements humains dont les autres tirent leur origine" (MAUSS, 1909a, p. 92). Além disso, as variadas sociedades

6 Não queremos reduzir a questão a um único fator, mas apenas indicar que há, também, o fator acadêmico, impossível de ser ignorado: a decisão de Mauss de fazer uma tese sobre a origem da prece entre os povos australianos antes de existir uma etnografia que oferecesse uma descrição ritos orais entoados durante as cerimônias religiosas desses povos. 
australianas possuem um fundo comum, isto é, formam uma civilização, o que as torna "un groupe éminemment favorable à des recherches sur l'ensemble d'un rituel et de ses variations" (MAUSS, 1909a, p. 94). Tal civilização apresenta, quanto às suas instituições religiosas, um elevado grau de diversidade na escala evolucionária, o que permitiria determinar o desenvolvimento dessas instituições ao longo do tempo. Ainda assim, a existência da prece entre os indígenas australianos era contradita pelos principais etnógrafos: Spencer e Gillen classificavam como mágicos todos os ritos australianos, excluindo a possibilidade de existência de qualquer fenômeno religioso; já Strehlow, apesar de reconhecer a existência de deuses australianos, afirma não ter encontrado oração entre os Arunta. Mauss, por outro lado, censura os etnógrafos por não conseguirem desvencilhar a noção de prece de sua forma cristã e, consequentemente, serem incapazes de entender como diferentes tipos de prece podem existir sem que se pareçam em sua forma ou conteúdo com aquelas encontradas no cristianismo. Com efeito, “[1]es observateurs étaient naturellement hors d'état d'apercevoir ce qu'il peut y avoir de commun entre une prière chrétienne et un chant destiné à enchanter un animal. De là leurs dénégations" (MAUSS, 1909a, p. 116). Contra esse preconceito cristão na análise dos fenômenos religiosos, Mauss contra-argumenta que "[p]our découvrir la prière en Australie, il faut l'avoir ramenée à ses éléments essentiels, et avoir appris à ne pas voir toutes les choses religieuses à travers des idées chrétiennes" (MAUSS, 1909a, p. 115). Ao definir a prece em termos de sua função dentro de um sistema religioso, isto é, como ritos orais que se dirigem a coisas sagradas, Mauss pretende mostrar como esses ritos "peuvent avoir la nature et les fonctions de la prière sans avoir l'allure morale, la valeur psychologique, la teneur sémantique des discours religieux auxquels nous avons l'habitude de réserver ce nom" (MAUSS, 1909a, p. 117). Com efeito, a perspectiva evolucionária empreendida por Mauss sustenta que os ritos orais australianos contém, em germe, "tous les éléments essentiels des rites plus complexes et plus épurés auxquels les religions idéalistes réservent cette dénomination” (MAUSS, 1909a, p. 103).

Para subsidiar essa posição, Mauss seleciona três conjuntos de fatos que sugerem a existência de ritos orais dirigidos a seres sagrados australianos. Temos, em primeiro lugar, os ritos orais dirigidos aos animais auxiliares totêmicos, nos quais o indígena invoca o nome do animal homônimo ao seu totem e imita seu som com o objetivo de obter uma boa caça e proteger-se dos perigos que envolvem essa atividade. 
Tais ritos orais fazem um apelo aos intermediários sagrados, apelo esse situado no limiar entre entre invocação religiosa e evocação mágica. Mauss designa essas práticas como ritos de apelo ao totem que ocorrem, principalmente, durante as festas mais importantes do calendário australiano. Em segundo lugar, Mauss relata o culto aos grandes espíritos ligados a certas regiões da Austrália, no qual o indígena deve se dirigir ao espírito e dizer pertencer àquela mesma região para evitar ser atingido por uma torrente ou outro fenômeno enviado pelo espírito. Nesse caso, tais ritos têm mais a função de conjurar do que de adorar: pede-se um favor ao espírito e lhe é indicada a razão para contar com sua benevolência. Em terceiro lugar, haveriam, entre várias tribos do centro e do oeste da Austrália, os cânticos para o grande deus, nos quais, muitas vezes, "s'est servie de geste pour remplacer le mot" (MAUSS, 1909a, p. 131). Com efeito, esse conjunto de fórmulas simples dirigidas a seres sagrados "nous montrent seulement les civilisations australiennes s'engageant vers la voie qui mène à la prière aux dieux, aux grands dieux" (MAUSS, 1909a, p. 132). Esse conjunto de fatos atesta a coexistência de diferentes estágios da prece na civilização australiana e, ao mesmo tempo, convida a entender a riqueza do rito oral elementar que figura nas principais cerimônias religiosas australianas - que, a despeito de sua aparente simplicidade, é dotado da mesma natureza e da mesma função social que as orações de outros sistemas religiosos. Se "une nomenclature empreinte de théologie refuserait sans doute, le nom de prières", Mauss pretende demonstrar como essas fórmulas "sont la masse, le centre de gravite du rituel oral australien" (MAUSS, 1909a, p. 139). No entanto, o método exclusivamente filológico seria inapropriado para tal, na medida em que a prece australiana não constitui um rito autônomo e é, na maior parte dos casos, apenas "une expression sommaire des sentiments violents" que os atos exaltados supõem (MAUSS, 1909a, p. 141). No rito elementar australiano seria impossível, portanto, isolar os atos orais dos gestos manuais, na medida em que ambos são frações de um único e mesmo ato. Por essa razão, os ritos orais australianos devem ser investigados necessariamente em seu meio ritual correspondente, isto é, no conjunto das cerimônias religiosas, totêmicas e de iniciação. A esse respeito, Mauss propõe investigar particularmente as cerimônias chamadas intichiuma, definidas como "des cérémonies des clans totémiques qui ont pour effet d'agir directement et, dans une certaine mesure exclusivement, sur l'espèce ou la chose totémique" (MAUSS, 1909a, p. 144). Seria preciso, ainda, proceder 
à comparação do intichiuma dos Arunta com o intichiuma dos Warramunga - grupo investigado na segunda etnografia de Spencer e Gillen (1904) -, mostrando como tribos distintas possuiriam preces equivalentes.

Grupo mais extensamente investigado pelas missões etnográficas britânica e alemã, os Arunta dedicam-se a longas festas de iniciação em que "de purs festins et de pures réjouissances se mêlaient aux rites les plus sacrés, occupaient des mois entiers" (MAUSS, 1909a, p. 148). Em um dos primeiros documentos etnográficos sobre os Arunta, o missionário alemão Schulze ${ }^{7}$ já descrevia fragmentos do intichiuma nos quais constavam os cantos tjurunga ${ }^{8}$, isto é, preces para as substâncias alimentares. Schulze já assinalava o caráter religioso e coletivo dessas cerimônias que, segundo o autor, serviam "as reminders, and extol the past, conjoined with prayers that these animals [...] may again appear in the same numbers" (SCHULTZE, 1891, p. 243). "Their aboriginal songs", prossegue, "are very monotonous and monosyllabic" (SCHULTZE, 1891, p. 220). Conjugado ao canto, eles executam uma dança que consiste em "keeping time to the singing by vigorous stamping with the feet, endeavoring at the same time to imitate the peculiarities of the particular animal that lends its name to the festival" (SCHULTZE, 1891, p. 243). Enquanto dançam, "they beat time to it with their hands, or slapping their bare legs, or with their tnuma (short stick) upon a trough. The tone moves from quinte to quinte monotonously", e cada verso "consists of three to five words, which are endlessly repeated until they change it for another to the same tune" (SCHULTZE, 1891, p. 220). Mauss, por sua vez, observa que esses ritos orais podem ser reduzidos a gritos, grunhidos, ou até mesmo a ruídos rítmicos e gestuais que integram a performance do animal tjurunga. Seja qual for o meio de expressão do rito, oral ou manual, até em suas formas mais simples ele segue um mesmo padrão de repetição seguido de pausas também regulares, ou seja, uma métrica e um ritmo constantes. "La répétition est essentielle au chant tjurunga", assinala Mauss (1909a, p. 157). Na sequência, Schulze apresenta os cânticos arunta seguidos de sua tradução aproximada:

1. "Tijatitjana jala ramana!"

"Large Emu, many tracks!"

2. "Magatjagatjana werilankana!"

"Innumerable Emu have been here!"

7 Para uma análise da missão alemã, e de Schulze em particular, cf. Anna Kenny (2017).

8 Variante alemã de churinga. 


\section{3. "Lambulambila laintjirbmana!"}

"The [name of a bird] is upon mountain-sized water!"

4. "Galbmantalanta janiau gatitjalanta janiau!"

"Honey much, Yes! yes! Very much; yes! yes!"

(SCHULTZE, 1891, p. 243-244).

Segundo a análise de Mauss, o quarto verso seria aquele em que a expressão imperativa e de extraordinária intensidade do desejo seria mais evidente: mel muito, sim sim!; muito muito, sim sim! O terceiro verso, por sua vez, parece ser a rubrica musical de um mito, possivelmente ligado à festa do pássaro lambulambila, em que o pássaro aparece sobre o buraco d'água na montanha. Já os dois primeiros versos são parte do tjurunga da ema e remontam ao episódio mítico de perseguição de rastros do animal durante a caçada. Ambos estão relacionados e se caracterizam tanto pela repetição contínua quanto pelas pausas métricas que os ritmam. Do ponto de vista mais geral, todas essas fórmulas são classificadas por Mauss tendo por base tanto sua estrutura ritual quanto literária, e se aplicam a todos os ritos orais do intichiuma. No que diz respeito a sua estrutura ritual, as fórmulas são: 1) "musicales c'est-à-dire mélodiques et rythmiques"; 2) “directrices des gestes, mimes ou danses"; 3) “collectivement chantées"; 4) "répétées d'une façon monotone" (MAUss, 1909a, p. 161). No que diz respeito à estrutura literária, as fórmulas são: 1) simples, reduzindo-se a gritos ou pequenas frases; 2) descritivas de um tempo-meio em que o passado mítico e o efeito futuro desejado se confundem; 3) ininteligiveis, pois fazem uso de uma linguagem incompreendida pelo público; 4) eficazes, pois subentendem a realização do efeito desejado. No intichiuma, então, a repetição da fórmula acompanhada da dança produz um efeito de tal intensidade que se passa da rememoração do mito "au souhait immédiatement efficace, à la démonstration de l'effet indiqué comme s'il était, lui aussi, donné" (MAUSs, 1909a, p. 160). Ao analisar essa relação entre canto e dança, Mauss diz o seguinte:

elle [la formule] est nettement musicale, rythmique et méthodique; c'est un chant. Ce chant, ou bien, sert à accompagner la danse d'un acteur ou d'un petit nombre de mimes, ou bien, après qu'il a accompagné la danse mimée, et s'est ainsi acquitté de sa fonction, il se continue indéfiniment, sur le même rythme plus ou moins précipité, sur le même thème transporté tout au plus d'octave en octave et de quinte en quinte. Fortement lié au rite manuel, auquel il est asservi, puisqu'il n'a d'autre fonction que de le rythmer et de le diriger, il peut se poursuivre, tel un geste stéréotypé quand la danse de l'acteur fatigué cesse. Et encore, d'après Schultze, nous pouvons induire que la mesure que l'on continue à battre avec les bâtons de musique (tnuma) constitue au moins un geste rituel. Le rythme, la métrique de la 
formule proviennent de la destination dramatique (MAUSS, 1909a, p. 155-156; grifo nosso).

No trecho acima, é interpretada a relação entre canto e dança nas cerimônias intichiuma nos termos da sua função dramática, privilegiando os aspectos técnicos da performance. Para além do conteúdo, a fórmula possui uma forma musical, ou seja, ela cristaliza uma certa métrica e um ritmo que organizam a performance. O ritmo, mais uma vez, aparece em primeiro plano, como uma categoria associativa por excelência, capaz de propiciar a associação dos presentes na cerimônia. Além disso, o ritmo também coordena os ritos orais e manuais: ele dirige a cerimônia, uma vez que todos os gestos e sons estão a ele subordinados. A dança, por sua vez, é encabeçada por um ator e possui, tal qual havia avaliado Hubert, uma forma mimética, que remete tanto à técnica empregada na performance, quanto ao mimo greco-romano. Com efeito, Mauss reimagina o intichiuma tendo por modelo o gênero dramático popular greco-romano; mas, tal qual Hubert, o autor concebe essa combinação entre gestos e sons estereotipados do ritual arunta como o próprio germe religioso do mimo enquanto gênero dramático.

A caracterização do rito oral realizada a partir de Schulze sublinha o caráter coletivo, estereotipado e mecânico do rito arunta. O caráter sumário do relato de Schulze, contudo, dificulta a observação de todas as crenças e sentimentos que entram em ação durante o intichiuma para além de "cette force brutale des mots" (MAUSS, 1909a, p. 162). Com efeito, Mauss indicou que as etnografias mais detalhadas de Spencer e Gillen e de Strehlow - que estudaram a mesma região sob pontos de vista distintos - serviriam para elaborar um quadro mais completo e mais preciso do ritual arunta e, consequentemente, de seu rito elementar. À diferença de Schulze, que não distingue as cerimônias observadas, Spencer e Gillen afirmam que o intichiuma é uma cerimônia exclusiva do clã, cuja periodicidade "is largely dependent on the nature of the season" (SPENCER; GILLEN, 1899, p. 169). Em sua interpretação dessa asserção de Spencer e Gillen, Mauss afirma que tais cerimônias "sont parfaitement réguliers, annuels, répétés à chaque saison" (MAUSS, 1909a, p. 163; grifo nosso). Em seguida, Mauss seleciona o intichiuma do clã das lagartas witchetty, que tanto Spencer e Gillen quanto Strehlow haviam contribuído para o conhecimento dos ritos e dos mitos. A reconstrução da cerimônia por Mauss divide-se em três atos, com foco no papel dos cantos executados ao longo das 48 horas de duração. No ato de abertura, os presentes 
reúnem-se em volta de um grande bloco de quartzo maegwa, o grande inseto adulto, e alatunja, o chefe local, começa a cantar e a bater na pedra com sua bacia ampara; os demais presentes retomam o mesmo canto, ao mesmo tempo em que batem no bloco com suas ramagens. Mauss censura Spencer e Gillen por estes terem negligenciado tanto o rito quanto a fórmula, limitando-se a dizer que o refrão consistia em "une invitation à l'animal de déposer ses œufs" (MAUSS, 1909a, p. 165). Repetem-se os mesmos canto e gesto, mas agora dirigidos às pedras churinga, que representam os ovos que os ancestrais, homens-lagartas, carregavam. Tudo se passa como uma encenação do feito ancestral, "à ce même endroit, sur ces mêmes pierres, car lui aussi avait pratiqué l'intichiuma" (MAUSS, 1909a, p. 166). Em seguida, seguindo o exemplo ancestral, que divertiu-se lançando os ovos churinga ao ar, alatunja lança as pedras churinga ao ar da mesma maneira. Os dois momentos são acompanhados pelo incessante canto dos demais presentes. Em ambos os casos, Mauss faz citações diretas do texto de Spencer e Gillen, com modificações que não constavam no original:

\section{Spencer e Gillen}

while the older men again chant invitations to the animal to come from all directions and lay eggs (SPEnCER; GiLlen, 1899, p. 172)

the other members of the party run up and down the face of the rocky ledge, singing all the time (SPENCER; GILlen, 1899, p. 173).

\begin{abstract}
Mauss
"cependant que les vieillards chantent à nouveau des invitations avec animation : qu'ils (les insectes) viennent de toutes les directions et déposent leurs œufs" (SPENCER; Gillen apud Mauss, 1909a, p. 166; grifo nosso).
\end{abstract}

les autres membres du clan, montent et descendent tout au long de la paroi rocheuse "chantant de façon continue, nous ne savons quoi, mais évidemment une phrase qui décrit ce geste de l'ancêtre" (SPENCER; GILLEN apud Mauss, 1909a, p. 166-167; grifo nosso).

Ambas as alterações não se referem apenas a questões de estilo; na verdade, introduzem novos elementos, necessários para a análise proposta por Mauss. No primeiro caso, temos a introdução de um adjetivo que marca a interpretação de Mauss acerca do estado emocional dos homens enquanto performam o cântico: eles não cantam de maneira indiferente ou fria, mas, ao contrário, cantam com animação, ou seja, exaltação, alegria 
e entusiasmo. Já no segundo caso, temos a introdução de uma inferência a respeito do conteúdo do canto: este, para Mauss, só poderia conter uma fala que descrevesse o gesto ancestral. Tanto a indicação sobre a animação, quanto a inferência sobre o conteúdo do canto visam preencher as lacunas deixadas pelos etnógrafos britânicos. Essas modificações também acabam por preencher lacunas em favor do próprio esquema de análise desenvolvido por Mauss, ou seja: 1) é salientada a intensidade dos sentimentos engendrados durante o ritual; e 2) é apontada a unidade entre gesto e fala, característica dos ritos religiosos elementares.

Findo o primeiro ato, o inseto adulto é encantado e deposita seus ovos. No segundo ato, os participantes voltam ao campo lentamente - à maneira das lagartas - e desenterram as pedras que representam as crisálidas, isto é, os ovos do inseto. Enquanto retiram e limpam as pedras sagradas, esfregando-as umas nas outras, os participantes entoam um canto monótono e contínuo sobre crisálidas, o mesmo que o seu antepassado, chefe do clã, também cantara. No terceiro ato, os homens pintam o emblema sagrado do totem no próprio corpo e, em fila indiana, marcham agitando os arbustos em direção à umbana, uma longa cabana de folhas que, segundo a interpretação de Mauss, representaria o casulo. Um ancião que está na entrada da cabana, ao avistar o grupo de atores do rito, canta: “Ilkna pung kwai, Yaalan nik nai, Yu mulk la, Naantai yaa lai” (MAUSS, 1909a, p. 168). Apesar de não haver tradução, Mauss reconhece a métrica dos versos e acredita que eles sejam, baseando-se na filologia de Strehlow, uma fórmula de saudação. O grupo de homens se aproxima e, da mesma forma que o ancestral, alatunja lança um olhar às mulheres. Todos entram na umbana e, então, começam a cantar a respeito das transformações da lagarta totêmica, enquanto os membros da outra fratria permanecem imóveis com o rosto virado para o chão, permanecendo assim até o fim. Os atores rastejam para fora da cabana; depois retornam a ela rastejando e cantando, até que começam a se separar lentamente e o canto cessa. Os atores, então, passam a noite na umbana cantando para witchetty até o amanhecer, donde seguem-se os ritos de sacramento e de saída.

Feita a reconstrução das linhas gerais do intichiuma, Mauss afirma que "ces rites oraux répondent tous au type général que nous avons constitué : ce sont des chants monotones rythmés, attachés à des rîtes manuels (danses ou gestes collectifs)" (MAUSS, 1909a, p. 170). Esses ritos são considerados fórmulas religiosas que ora ordenam a 
reprodução da espécie totêmica, ora descrevem eventos míticos ligados à mesma. Como já havia observado Schulze, o caráter precatório do rito também é observado na etnografia de Sepencer e Gillen: o apelo para que o animal totêmico ponha os ovos; para que nasçam as lagartas dos ovos; para que façam seus casulos; e, enfim, para que metamorfoseiem-se em borboletas. Em todos os casos, trata-se de um pedido à espécie totêmica que "incite à satisfaire aux vœux du clan, interprète de la tribu" (MAUSS, 1909a, p. 171). No entanto, tal apelo não é concebido como um pedido que possa ser recusado pelo totem: é, antes, uma sugestão imperativa à qual o totem deve conformarse. Assim como as primeiras lagartas obedeciam às ordens do chefe ancestral, é preciso que elas "se métamorphoser régulièrement comme elles voient que les hommes le font dans leur drame rituel" (MAUSS, 1909a, p. 172). Da mesma maneira, a autoridade de tais fórmulas não advém da força mágica dos vivos, mas, antes, ela advém da própria autoridade do chefe ancestral, que repetia as mesmas palavras às lagartas no tempo imemorial em que homens e animais “ne faisaient qu'un, voyageaient, déposant leurs œufs, les churinga réceptacles des âmes des morts, des âmes des enfants des hommes et des substances des bêtes" (MAUSS, 1909a, p. 173). A linguagem das fórmulas é desconhecida e mesmo incompreensível para os membros do grupo porque é baseada em um palavreado místico, arcaico e extraordinário, tal qual aquele empregado pelos ancestrais no tempo do alcheringa. Com efeito, esses ritos possuem tanto um valor mítico - porque foram empregados na origem da espécie -, quanto um valor experimental - na medida em que sua eficácia é verificada repetidamente a cada estação, com o nascimento de novas lagartas. Não obstante, as fórmulas são entoadas apenas em lugares específicos, sagrados, e apenas diante dos churinga, ou seja, os ritos em questão são encantamentos com o objetivo de animar as pedras sagradas e transformá-las em seres vivos. Conforme observa Mauss:

La formule est un moyen de faire revivre les ancêtres mythiques qui résident dans les pierres. De plus, comme les métamorphoses successives de l'animal sont liées à sa reproduction, [...] on peut comprendre que ces descriptions des mythiques vicissitudes de l'espèce, et ces exhortations à les reproduire ont pour effet d'exciter ces corps et ces âmes des churinga à cette multiplication des chenilles que le rite recherche. De même que les chants érotiques agissent sur les désirs des hommes, de même les formules poussent les êtres, bêtes, hommes, dieux, revivifiés par le rite, par la voix, à accomplir, de façon prospère, leur destin (MAUSS, 1909a, p. 175; grifo nosso). 
De acordo com a análise de Mauss, os ritos orais e manuais do intichiuma objetivam, em última análise, impelir à vida toda a rede de seres articulados em torno da noção indígena de totem - homens, animais e ancestrais divinos. O canto impele ao desejo de realizar, cada um à sua maneira, o próprio destino. À metamorfose do ancestral se sucede, então, um conjunto de outras transformações, tanto da espécie totêmica quanto dos seus parentes do clã. Nesse sentido, qual seria o próspero destino comum a animais, humanos e deuses? De acordo com Mauss, é a sua contínua transformação, tema que constitui a metanarrativa do drama sagrado arunta. O manuscrito da tese é interrompido aqui, no meio do terceiro capítulo do Livro II. Apesar de permanecer em aberto a explicação da eficácia desses ritos orais australianos, no curso "Théorie des formes élémentaires de la prière", ministrado na EPHE durante o ano letivo de 1902-1903, Mauss já expunha sua hipótese sobre a eficácia do rito religioso oral australiano. No resumo do curso, Mauss afirma ter analisado todos os documentos disponíveis sobre as religiões australianas ${ }^{9}$ para elaborar essa hipótese. Conforme o autor, a explicação residiria nos estados de êxtase coletivo gerados durante as cerimônias religiosas:

Ce caractère général étant posé, il s'est agi d'expliquer que des hommes aient pu croire à l'efficacité religieuse de telles paroles. Par une analyse des conditions religieuses et sociales où ces formules sont répétées, il a été montré comment une telle croyance était possible. Il a été enfin retrouvé, dans les faits exposés au cours du travail de ces deux, un certain nombre d'états d'excitation et d'extase collective, où, les documents l'établissent, une sorte de croyance hypnotique se généralise dans tout un groupe d'individus. - Ces états ont paru explicatifs des formes élémentaires, non seulement de la prière, mais même de tout rite oral en général (MAUSS, 1903e, p. 99; grifo nosso).

Segundo a hipótese do curso de 1902-1903, a eficácia religiosa dos ritos elementares australianos - por sua vez, ao mesmo tempo orais e gestuais - seria explicada por $\mathrm{um}$ certo número de estados de êxtase coletivos que, tomados em conjunto, produzem uma crença hipinótica generalizada em todo o grupo de participantes do drama sagrado australiano. A crença é hipnótica no sentido que o drama produz o êxtase e este, por sua vez, torna os presentes mais suscetíveis às ideias e práticas realizadas durante o ritual, que a elas aderem sem oferecer resistência.

Nos anos subsequentes à circulação da primeira versão do manuscrito, Mauss continuou trabalhando na tese, colaborando para a publicação da extensa etnografia de

9 Até 1903, os dois principais documentos disponíveis eram os de Schulze (1891) e Spencer e Gillen (1899), que são o material mais detalhadamente analisado no manuscrito de 1909. 
Strehlow e oferecendo cursos regulares na EPHE. Após a publicação dos dois primeiros volumes da etnografia de Strehlow (1907 e 1908), Mauss, que sabia que Strehlow havia coletado mais de 500 versos arunta, passou a se corresponder e a colaborar diretamente com o autor no intuito de viabilizar a publicação dos volumes seguintes ${ }^{10}$. Mauss tinha a esperança de que a publicação das fórmulas ausentes no trabalho de Spencer e Gillen o ajudaria a entender melhor "les rapports entre la formule et le rite manuel, entre la représentation totémique, le rite oral et le mythe" (DURKHEIM; MAUSS, 1910, p. 81). Com efeito, Mauss celebrou a publicação do terceiro volume de Strehlow (1910 e 1911), que oferecia, pela primeira vez, a transcrição e a tradução das fórmulas cantadas pelos Arunta: "Nous possédons ainsi un précieux recueil de 1500 vers aranda qui forme une sorte de Rig Veda australien. Les travaux futurs sur ces rituels pourront s'appuyer sur une solide base philologique" (MAUSS, 1913b, p. 103-104). No entanto, apesar de suprir a lacuna deixada por Spencer e Gillen, Mauss sugere que o trabalho filológico de Strehlow ainda demandaria novas contribuições sobre os rituais arunta, que conectassem os versos sagrados aos ritos manuais a partir da observação direta das cerimônias performadas pelos nativos. Isso porque, apesar da longuíssima experiência de campo entre os Arunta, bem como de seu rigor em relação à exposição das condições de obervação, Strehlow jamais acompanhara uma cerimônia religiosa indígena, por receio de que isso comprometesse sua credibilidade como cristão (KENNY, 2013, p. 121). Ainda que perante a ausência de observações etnográficas que conetassem ritos orais e manuais, Mauss utilizou as fórmulas coletadas por Strehlow e ministrou cursos na EPHE sobre as origens do ritual formulário australiano entre 1908 e 1914. Ao longo dos cursos, Mauss despendeu específica atenção aos "formulaires du culte de l'eau", considerando essa cerimônia representativa e sublinhando a relação dos "chants à forme dramatique de ce culte" (MAUss, 1910e, p. 107). Nos anos seguintes, Mauss passou a acompanhar a evolução do rito oral a partir da linguagem religiosa presente em todo o conjunto de rituais mágicos, jurídicos e morais australianos (MAUSS, 1913a, p. 24). Segundo o autor, a linguagem religiosa permearia essas diferentes instituições australianas uma vez que todos derivariam de um mesmo "'type de rituel formulaire, où la prononciation des mots rythmés était douée d'une valeur à la fois pratique, suggestive, esthétique et morale" (MAUSS, 1914, p. 78). Enfim, os resultados parciais da

10 Strehlow (1913) agradece a Mauss pelo auxílio no quarto volume da série. 
investigação sobre a origem do ritual formulário australiano são apresentados por Mauss no resumo de curso de 1910-1911 da seguinte maneira:

Cette année, le cours a porté à la fois sur les formes primitives du culte oral des grands dieux en Australie [...] On a établi à ce propos l'unité des cultes d'initiation et des cultes totémiques, et tenté de reconstituer le rituel qui leur a servi d'origine commune.

Puis, pour préparer l'explication définitive de la croyance à l'efficacité des mots, on a étudié de façon détaillée les divers rituels, non strictement religieux, mais magiques, juridiques ou esthétiques, qui permettent de concevoir les rapports du rituel oral avec les autres phénomènes religieux et sociaux. Une étude du corrobora, de la ronde dramatique en Australie, a permis en particulier de montrer les relations directes des phénomènes esthétiques et des phénomènes religieux : poésie, musique, danse et mimique soutiennent en effet, avec la religion et ses modes de parler, des rapports étroits et déjà explicatifs. Le transport dans un monde meilleur et autre est, à ce stade de la civilisation, opéré par les mêmes voies dans le culte et dans l'art, relativement indistincts (MAUSS, 1911a, p. 86; grifo nosso).

O resumo citado permite-nos confirmar duas tendências previamente constatadas nos escritos de Mauss. A primeira é a identificação da unidade entre os cultos totêmico e de iniciação observados na Austrália, ambos considerados religiosos, seguida da tentativa de reconstruir retrospectivamente o ritual elementar a partir do qual esses rituais religiosos observados etnograficamente evoluíram. A reconstrução hipotética do ritual religioso elementar, considerado a matriz de todos os fenômenos sociais, permite portanto, determinar tanto a origem das instituições particularmente religiosas quanto a origem religiosa das demais instituições não religiosas. Já a segunda tendência diz respeito à relação estreita e direta entre fenômenos religiosos e estéticos, presente na teoria do drama sagrado e corroborada em uma série de análises anteriores. No caso australiano, tanto os rituais dramáticos quanto as demais expressões estéticas tematizam os mesmos transporte e comunicação entre mundos amplamente narrados na mitologia australiana. Embora jamais terminada, a tese sobre a origem da prece a partir do estudo nos rituais elementares australianos pretendia situar o fenômeno dentro do quadro teórico do drama sagrado, no qual os fenômenos religiosos elementares eram reduzidos a um conjunto de juizos de valor (ideias) e expressões estéticas (práticas). Eis o plano de capítulos da tese: 


\section{Plano de capítulos de La prière ${ }^{11}$}

\section{Livro I}

Capítulo 1. Introdução geral

Capítulo 2. Histórico da questão, método empregado

Capítulo 3. Definição inicial

\section{Livro II - Natureza dos ritos orais elementares}

Capítulo 1. Histórico da questão e delimitação do assunto

Capítulo 2. Existem preces na Austrália?

Capítulo 3. As fórmulas do intichiuma

Capítulo 4. Cerimônias totêmicas de iniciação

Capítulo 5. Formas do culto totêmico, ritos de iniciação, sacramento totêmico

Capítulo 6. Caráter religioso do ritual australiano e sua evolução

Capítulo 7.

Capítulo 8. Atnatu, o grande deus

\section{Livro III}

Parte I

Capítulo 1. Ritos mágicos, encantamentos e feitiços

Capítulo 2. Mitos

Capítulo 3. O nascimento da fórmula ritual; estados de êxtase

Capítulo 4. Relações entre ritos manuais e ritos orais; a festa

\section{Parte II}

Capítulo 1. Condições sociais e tecnológicas; fratrias e classes matrimoniais

Capítulo 2. Condições rituais e estados mentais; o tempo do alcheringa

Capítulo 3. Condições rituais e estados mentais; interjeições religiosas

Capítulo 4. Interdições, ronda dramática (corrobore), espíritos da natureza

A lacuna de estudos etnográficos que combinassem conhecimento filológico e observação ritual só foi preenchida muitas décadas depois por Theodhor Strehlow, filho de Carl Strehlow nascido durante a missão etnográfica do pai na Austrália e que se tornou uma das maiores autoridades sobre os Aranda ${ }^{12}$. Sua última e mais importante obra, The Songs of Central Australia (1971), forneceu "a deep insight into the dramatic heritage of these people", conforme expresso "through the media of poetic-song and

11 Plano elaborado a partir da indicação dos capítulos e seus respectivos temas ao longo das mais de 400 notas de rodapé da tese. Os títulos atribuídos por Mauss estão em itálico; os demais consistem nos temas conforme indicados nas notas. $\mathrm{O}$ capítulo 7 não é mencionado.

12 Variação alemã para Arunta. 
narrative forms, revealing a religious and symbolic quality and intensity to their life" (BERNDT, 1972, p. 205). No livro, Strehlow ${ }^{13}$ analisa em detalhe a estrutura musical, rítmica e literária dos cantos aranda, bem como os temas e assuntos neles tratados. Apesar de Strehlow não ter tido acesso à tese inacabada de Mauss, Howard Morphy (2003) sugere alguns possíveis diálogos entre os trabalhos de ambos os autores, dos quais destacamos apenas dois. O primeiro diz respeito à identidade funcional dos cantos indígenas e das preces cristãs: "Just as prayer in Christianity is performed in a variety of contexts from state assembly to individual contemplation, so too is the case with religious performance in Aboriginal Australia", uma vez que a prece "or its analogues are seen to occur at burial ceremonies, in initiation, at night before going to sleep, as part of corporate ritual or as individual expression" (MORPHY, 2003, p. 152). Conforme demonstramos, Mauss pretendia exatamente mostrar como diversos tipos de prece destinadas aos mais variados tipos de culto coexistiam no território australiano. Sua tese pretendia reconstruir, de um ponto de vista evolucionário, desde os cantos totêmicos, coletivos, originários e mágico-religiosos, até as preces mais individuais e dirigidas ao grande deus. Para Mauss, a prece elementar australiana era um fenômeno religioso tão distinto, complexo e variado quanto a variante cristã; ao mesmo tempo, considerava que ambas cumpriam a mesma função na vida religiosa indígena e cristã e, portanto, poderiam ser designadas pelo mesmo termo. Já o segundo diálogo diz respeito à criatividade dos cantos australianos. Conforme assinala Morphy, "the song words become the names of the ancestral beings themselves and over time there is a conversion from descriptive attributes of place to proper names" (MORPHY, 2003, p. 151), seguida de uma mudança na entonação e no ritmo dos cantos. Tal dimensão criativa no uso da língua dos ancestrais é manifestada por Strehlow quando este afirma que "[t]his gleaming light of the poetry transfigured the landscape of central Australia for the natives into a home fit for the totemic ancestors" (STREHLOW, 1971, p. 382). Com efeito, mesmo sem ter nenhum contato com o trabalho de Mauss, Strehlow parece subsidiar a tese da unidade entre estética e religião dos ritos orais australianos:

the song, like dancing, dramatic performances, and art generally, were associated with religion and with religious themes; [...] In Australia, the singing of the traditional sacred songs was believed to confer upon the native singers many of the powers once possessed by the totemic ancestors, whose changed and immoral

13 Para uma análise da vida e obra de T. H. G. Strehlow, cf. Jason Gibson (2017). 
bodies could still be seen at the ceremonial sites. [...] The Central Australian natives believed that they were composed not by men but by the totemic ancestors themselves. [...] There was hence no taint of human fabrication or of illusory poetic dreaminess associated with the sacred songs. To the natives their poetry was the absolute expression of both Truth and Beauty (STREHLOW, 1971, p. 244; grifo nosso).

Nos rituais religiosos, os cantos sagrados ou preces são acompanhados danças; assim como as performances mimetizam os atos dos ancestrais, os cantos contém o poder conferido pelos ancestrais, seus verdadeiros criadores. Para Strehlow, portanto, os cantos aranda transfiguram a ação do poder sagrado no mundo, sua verdade, por meio da expressão poética, sua beleza. Da mesma maneira, Mauss havia sublinhado a estrita relação entre os fenômenos religiosos e estéticos, demonstrando como os rituais arunta em geral e os ritos orais em particular tinham a capacidade de transfigurar, por meio dos cantos e danças, as transformações dos ancestrais, dos homens e da espécie totêmica. Embora jamais tenha terminado a tese, Mauss foi pioneiro não apenas em chamar a atenção para "[the] lexical gap in the interpretation of Australian cultures", mas, principalmente, em visionar o potencial estético e criativo dos ritos orais australianos, "where relations with the spirit world are brought into being through words" (MORPHY, 2003, p. 153).

\subsection{Dos sistemas religiosos aos sistemas de prestações totais}

Em uma de suas resenhas sobre a obra de Wundt, Mauss observa que o fenômeno elementar é, "à la fois, brutale e comique, serve et libre, sentimentale et intellectuelle. Tout est mêlé” (MAUSS, 1910d, p. 61). Por conseguinte, mesmo quando as instituições sociais começam a se diferenciar nas sociedades indígenas, eles ainda mantém um vínculo mais ou menos explícito com as crenças e práticas religiosas dessas sociedades. Com efeito, Mauss passou a ampliar o escopo dos temas tratados em seus cursos na EPHE, seja para investigar "les rapports de la famille et de la religion dans l'Amérique du Nord" (MAUss, 1905c, p. 42), as relações entre "la religion et la famille en Australie" (MAuss, 1906b, p. 21), ou mesmo "les interdictions rituelles en Polynésie (les tabous)" - retomando, neste último curso, o tema de seu primeiro trabalho sobre as "interdictions rituelles et de leurs rapports avec la notion de sacré" (MAUSS, 1907e, p. 36). Ao mesmo tempo, Mauss também ampliou o escopo de sociedades estudadas, 
incluindo cursos sobre os "systèmes religieux africains" (MAUSS, 1907e, p. 36-37). Nesses cursos, o autor realizou uma crítica à noção de fetiche, considerada "le produit d'un malentendu, du surtout aux missionnaires, colons" (MAUSS, 1907e, p. 37). Com o advento de novas etnografias, Mauss sustenta que seria preciso substituir a noção missionária de fetiche pelas noções indígenas que designam essa força sui generis mágico-religiosa, tais como a noção bantu de nkiosi e éwé de $d z o$, ou seja, as noções equivalentes e comparáveis à noção melanésia de mana (MAUSS, 1908a, p. 41). No curso do ano seguinte, intitulado "Étude analytique et critique de documents concernant les religions de l'Afrique", Mauss registra que um de seus alunos havia feito “remarquables leçons sur les rapports entre les phénomènes religieux el les phénomènes économiques (le marché en particulier)" (MAUSS, 1909b, p. 43) Conforme atestam suas publicações desse período, tanto a conexão entre os fenômenos religiosos, jurídicos e econômicos, quanto o estudo comparado das sociedades indígenas da África, América do Norte e Oceania caracterizam a direção das pesquisas de Mauss até a eclosão da Primeira Guerra.

O primeiro conjunto de trabalhos diz respeito às relações entre religião e família, em que Mauss investiga "Le tabou de a belle-mère" a partir das etnografias sobre os povos australianos e africanos. De acordo com o autor, o caso do tabu da sogra seria apenas mais um daqueles em que seria possível observar, do ponto de vista jurídico, o estabelecimento de contratos entre grupos distintos a partir da observância de ritos positivos e negativos entre "groupes opposés et entre individus appartenant à des collectivités soit ennemies, soit simplement distinctes" (MAUSS, 1914c, p. 42). Em um curso do mesmo ano sobre as organizações jurídica e religiosa, Mauss investiga as "formes primitives de contrats collectifs passés entre les clans" nas etnografias africanas, americanas e melanésias, particularmente a respeito "des fiançailles et des relations entre alliés par mariage" (MAUSS, 1914a, p. 78). Considerando o casamento como "un rapprochement, un contrat entre deux clans obligatoirement séparés" (MAUSS, 1914c, p. 43), o tabu da sogra é observado em grupos de clãs exogâmicos, em que o genro e a sogra pertencem a fratrias opostas. Mauss interpreta esse tabu como um verdadeiro contrato entre o genro e a sogra, uma vez que "un des signes du contrat ce sont les prestations. Et il y a prestation” entre as partes (MAUSS, 1914c, p. 42). Ao comentar o caso bantu, Mauss afirma que a realização do casamento estabelece "un 
rapprochement [...] entre les deux clans, mais la barrière n'est pas complètement renversée. Dans la phratrie avec laquelle il s'est allié, le mari n'a de droit que sur sa femme ; sa belle-mère reste sacrée pour lui” (MAUSS, 1914d, p. 371). Com a realização dos ritos de casamento, a fratria contratada pelo genro divide-se em duas partes: $1^{\text {a }}$ ) a geração da esposa, "plus spécialement permise et consacrée au mari”; e $2^{\mathrm{a}}$ ) a geração da sogra, "plus spécialement interdite et sacrée pour le mari" (MAUSS, 1914c, p. 43; grifo nosso). Portanto, por meio de um ritual que realiza, ao mesmo tempo, a consagração da esposa e a interdição da sogra ao genro, o casamento institui, para Mauss, uma aliança entre as fratrias opostas.

O segundo conjunto de trabalhos diz respeito à origem da noção de moeda a partir de uma comparação entre sociedades indígenas africanas, norte-americanas e australianas. Em "Les origines de la notion de monnaie", Mauss propõe tratar a moeda não como um fato material, mas, antes, como fenômeno social, cujo valor e confiança atribuídos remontam à orgiem "d'une notion, d'une institution, d'une foi" (MAUSS, 1914b, p. 14). Tal origem diz respeito às noções elementares de poder, sustância e ação mágico-religiosas, isto é, às noções tipo mana tais como as de dzo ewé, manitou algonquin, logwa kwakiutl e churinga arunta. Mauss observa como esse poder sobrenatural se liga particularmente a certos objetos que são usados tanto para rituais mágico-religiosos quanto para rituais de troca, como o caso do "logwa talisman [...] le vrai nom des paraphernalia des clans, couvertures et cuivres blasonnés, véritable monnaie utilisée au cours des potlatch, de la série des échanges de clan à clan" (MAUSS, 1914b, p. 16). Da mesma maneira, "les churinga sont objets d'échange" para os Arunta e, mais especificamente, esses objetos sagrados "servent de mesure de valeur dans ces tribus" (MAUSS, 1914b, p. 17-18). Assim como o ouro comporta uma fé no seu poder, isto é, "la croyance que nous pourrons obtenir, grâce à lui, de nos contemporains les prestations" (MAUSS, 1914b, p. 19), Mauss observa que a posse desses talismãs cumpre uma função análoga nessas sociedades, na medida em que sua posse é cobiçada e confere ao detentor um poder análogo ao poder de compra. De acordo com a hipótese formulada, “[1] pouvoir d'achat de la monnaie primitive c'est avant tout, selon nous, le prestige que le talisman confère à celui qui le possède et qui s'en sert pour commander aux autres" (MAUSS, 1914b, p. 18). Para Mauss, portanto, seria o prestígio da posse de 
objetos mana que estaria na origem do poder de compra e, consequentemente, da noção de moeda.

Por fim, todas essas contribuições remontam à revelação que significou para Mauss a descoberta do potlatch no noroeste da América do Norte - uma instituição elementar que, segundo o autor, "affecte et domine tous les phénomènes sociaux de ces tribus" (MAUSS, 1906b, p. 21). Desde então, em seus cursos na EPHE, Mauss passou a desenvolver um ponto de vista cada vez mais teórico sobre instituições análogas ao potlatch existentes não só em outros povos americanos, como os Pueblo (MAUSS, 1908a, p. 42), mas também em povos africanos e melanésios. Conforme formulado pelo autor no curso de 1912-1913:

La conférence a été consacrée à une série d'explications [...] sur des Formes primitives de contrats collectifs, des échanges de prestations juridiques et religieuses entre groupes, clans et phratries dans la Nouvelle-Guinée, chez les populations papoues ou mélanésiennes. Il a été établi qu'on avait en pays mélanésien et papou des institutions comparables à celles des potlatchs du NordOuest américain (MAUSS, 1913a, p. 24).

De acordo com Mauss, o potlatch seria uma instituição - observada em povos dos três continentes - de estabelecimento de contratos entre grupos, entendidos como prestações rituais. Segundo a hipótese formulada pelo autor, tal instituição elementar conforma um sistema de "prestations religieuses, juridiques, économiques entre les phratries et les clans" (MAUSS, 1912, p. 33), sistema este que regula "la forme primitive de la rivalité et de la collaboration régulières entre les phratries" (MAUSS, 1911a, p. 86; grifo nosso). Assim, Mauss identifica o ritual como uma forma elementar de ação coletiva que engloba não só a vida religiosa, mas também política, jurídica e econômica das sociedades indígenas. Apesar de tal pesquisa ter sido interrompida pela eclosão da Primeira Guerra, essa hipótese será desenvolvida em detalhe, mais de uma década depois, em seu "Essai sur le don" (1925).

\subsection{Conclusão}

Ao analisarmos a contribuição de Mauss para o estudo dos fenômenos religiosos durante o período, pudemos observar como o autor deu continuidade à abordagem previamente estabelecida da sociologie religieuse, consolidando-a. Ao investigar a origem da prece e as tendências de desenvolvimento dos fenômenos religiosos, bem 
como o sistema de prestações das sociedades elementares, Mauss não só estendeu o escopo da teoria do drama sagrado, como também refinou a compreensão dos elementos estéticos da ação ritual. Concebendo-a como um conjunto de regras públicas de ação e pensamento ligadas à noção de força social sui generis, a ação ritual se expressa por meio de uma linguagem eminentemente estética, isto é, na forma de performances corporais e orais envolvendo canto, dança e encenações dramáticas. Para o autor, os rituais elementares são eventos de estética total, nos quais os elementos rítmicos e estéticos das artes dramáticas têm por função despertar e modular as emoções dos presentes e, consequentemente, desencadear estados de êxtase coletivo. Nesse sentido, Mauss considera a arte como um meio de criar emoções compartilhadas coletivamente pelos membros de determinada sociedade, remontando à sua função ritual elementar. Os estados de êxtase coletivo, por sua vez, engendram juízos de valor, ao mesmo tempo afetivos e racionais - tais como a ideia-força de mana ou de sagrado - que submetem o sentimento coletivo ao controle da experiência e funcionam como matriz de classificação, produção e segmentação de novas ideias e práticas coletivas. Conforme evidenciou na análise do drama sagrado australiano, os cantos e danças engendram uma sucessão de metamorfoses entre ancestrais, homens e animais totêmicos, fazendo da transformação a metanarrativa do ritual australiano. Dessa maneira, é a partir da interação entre a categoria de força social sui generis e as formas estéticas de expressão que a ação ritual produz as sucessivas transfigurações de ideias, práticas e sentimentos coletivos. Além de explicitar, tal como Hubert, a intrínseca relação entre fenômenos estéticos e religiosos, Mauss foi responsável por estabelecer a ação ritual como o modelo elementar de ação social que permite entrever as criações e transformações das ideias e práticas coletivas.

Ao acompanharmos o percurso realizado por Mauss durante esse período, pudemos observar o desenvolvimento da sociologie religieuse nos distintos planos de análise. Do ponto de vista metodológico, Mauss deu continuidade aos mesmos procedimentos de explicação genética previamente desenvolvidos, além de explicitar os procedimentos de crítica empregados para a interpretação de documentos etnográficos. Da mesma maneira, o objeto de análise manteve-se concentrado nas etnografias australianas, melanésias e norte-americanas, tendo sido incluídas, na última fase, as etnografias sobre as sociedades africanas. A esse respeito, enquanto o material 
australiano foi considerado particularmente pertinente para a reconstrução hipotética dos fenômenos de origem, as etnografias africanas, americanas e melanésias passaram a figurar dentro de um quadro comparativo das sociedades que mantinham um padrão de organização social semelhante. Nesse sentido, Mauss deu continuidade à proposta de uma sociologia comparativa e evolucionária que tem por objetivo conhecer as formas elementares e as tendências de desenvolvimento dos fenômenos religiosos. Do ponto de vista teórico, Mauss deu continuidade à teoria do drama sagrado, privilegiando, assim como Hubert, os elementos estéticos e afetivos da ação ritual. Entendida como a unidade básica de ação social, originalmente coletiva, a ação ritual mantém sua forma social mesmo em ações rituais individuais - seja na magia, seja na prece protestante. Nesse sentido, o autor avançou na compreensão da linguagem estética intrínseca à ação ritual, considerando as artes dramáticas como fenômenos sociais de transfiguração de sentimentos, ideias e práticas sociais. Conforme atesta o exemplo do potlatch, a ação ritual extrapola o domínio estritamente religioso e se generaliza como o modelo elementar de ação social em geral, organizando todo o sistema de prestações que está na base da vida econômica, jurídica e política das sociedades investigadas. Dentre as diversas implicações dessa tese, importa sublinhar como ela fundamenta a crítica de Mauss à tese de Huvelin acerca da origem mágica dos contratos e do direito individual, ao demonstrar tanto a origem coletiva dos contratos nos rituais de prestações entre grupos quanto o caráter social da ação ritual mesmo quando individualmente performada. Mauss, inclusive, acabou por dispensar a obrigação como índice dos fenômenos sociais, explicitando sua longa recusa da prescrição metodológica de Durkheim acerca das regras relativas à observação dos fenômenos sociais. Para Mauss, portanto, a ação ritual se torna o signo que designa tanto a origem religiosa quanto o desenvolvimento secular das instituições sociais.

Por fim, do ponto de vista da dinâmica da vida coletiva, Mauss privilegia a análise das tendências evolucionárias que extrapolam a alternância cíclica dos tempos sagrado e profano, dirigindo-se às transformações de longa duração das ideias e práticas coletivas. $\mathrm{Na}$ origem, as crenças e práticas religiosas são eminentemente coletivas, externas, materiais e indistintas. Conforme a análise das cerimônias elementares australianas, os ritos miméticos, ao mesmo tempo gestuais e orais, contém em germe todos os elementos essenciais que as religiões modernas chamam de prece. $\mathrm{O}$ decurso 
da evolução religiosa é, então, marcado pela tendência crescente de diferenciação, espiritualização e individualização das crenças e práticas religiosas, que se tornam cada vez mais individuais, etéreas e segmentadas, culminando tanto no deus interior e individual protestante quanto na meditação ascética budista. Sendo assim, além da tendência à espiritualização, a evolução do meio religioso acompanha a tendência de diferenciação e individualização do meio social geral. Todavia, o desenvolvimento de tais tendências não é linear: conforme progrediu a evolução da prece cristã, os estados de efervescência coletiva do cristianismo primitivo criaram um novo tipo de prece, mais subjetiva e baseada numa conversa pessoal com deus, ao passo que o catolicismo reintroduziu a prece coletiva e mecânica; assim, foi somente a partir da Reforma, séculos depois, que os germes da oração subjetiva e individual cristã puderam se desenvolver sob a égide do protestantismo. Conforme demonstrou Mauss, as ideias e práticas religiosas são criadas no meio ritual mais restrito, mas sua efetivação depende do desenvolvimento de outras instituições análogas, situadas no meio social mais amplo. Portanto, embora o meio ritual tenha o poder de criar novas ideias e práticas, foi somente no momento em que as tendências sociais de individualização e diferenciação social estavam plenamente desenvolvidas no meio social mais amplo que as formas religiosas subjetivas e individuais puderam, enfim, florescer. 


\section{Capítulo 5.}

\section{Durkheim e o desenvolvimento da sociologie religieuse: de volta à moral sob a égide de uma nova abordagem}

O presente capítulo dá continuidade à análise da contribuição de Émile Durkheim para a investigação dos fenômenos religiosos, tomando agora por referência o período concomitante ao desenvolvimento da sociologie religieuse por seus colaboradores do Année sociologique. Esse período compreende desde o artigo "Sur le totémisme" (1902) e do curso sobre a origem da vida religiosa (1907), até a subsequente publicação e divulgação de Les formes élémentaires de la vie religieuse (1912). A seleção dos trabalhos abrange todas as publicações de Durkheim durante o período mencionado que tratam dos fenômenos religiosos, incluindo artigos, cursos e resenhas. Nesse sentido, o capítulo apresenta a descontinuidade da abordagem previamente estabelecida da sociologie morale et juridique, centrada no funcionamento das regras de conduta, e a consequente assimilação da nova abordagem da sociologie religieuse que investiga a gênese das ideias e práticas coletivas nos meios rituais efervescentes, culminando na publicação de Les formes élémentaires de la vie religieuse em 1912. Conforme pretendemos demonstrar, Durkheim não apenas passa a enfocar os elementos estéticos e afetivos da ação coletiva nos meios rituais, como também extrapola essa abordagem para a investigação da gênese e da transformação das ideias e práticas pedagógicas, jurídicas e morais das sociedades europeias.

O capítulo está subdividido em cinco partes. Na primeira, tratamos da mudança na abordagem do totemismo australiano empreendida por Durkheim: mostramos como o autor abandona a perspectiva centrada na investigação do funcionamento das interdições alimentares e matrimoniais e passa a privilegiar a abordagem centrada na criação dos ideais coletivos nos meios rituais. Na segunda parte, analisamos o Livro II de Les formes élémentaires de la vie religieuse, enfocando a gênese e o desenvolvimento das ideias religiosas elementares nos meios sociais efervescentes australianos. Na terceira parte, tratamos do Livro III de Les formes élémentaires de la vie religieuse, com 
especial atenção à dimensão estética das práticas religiosas elementares, bem como à centralidade da ação coletiva no domínio religioso. Na quarta parte, analisamos como Durkheim extrapola o método empregado em Les formes élémentaires de la vie religieuse para a análise dos fenômenos pedagógicos, jurídicos, morais e intelectuais, seguindo traços dessa abordagem nos cursos que ele ministrou em Paris até a eclosão da Primeira Guerra. Por fim, na quinta parte do capítulo realizamos uma síntese da análise empreendida, sublinhando a mudança de orientação de Durkheim ao longo do período, bem como a centralidade da ação ritual para a abordagem da sociologie religieuse.

\subsection{Das regras de conduta aos ideais coletivos}

Em 1902, Durkheim publica seu primeiro artigo sobre o totemismo australiano, intitulado "Sur le totémisme". O trabalho consiste na sua primeira apreciação crítica da etnografia de Spencer e Gillen (1899), ficando restrito, no entanto, a reportar o totemismo às origens do parentesco, do casamento e da organização social. Apesar de reconhecer o caráter sagrado das crenças totêmicas e sua comparabilidade com outros sistemas religiosos, Durkheim afirma que “[s]ans doute, l'Arunta n'a des forces religieuses sur lesquelles il cherche à agir ou dont il croit subir l'influence qu'une représentation confuse" (DURKHEIM, 1902, p. 87-88). Para ele, o totemismo estaria baseado em duas regras essenciais, quais sejam: i) as interdições alimentares, "la défense de tuer et de manger l'animal ou la plante totémique"; e ii) as interdições matrimoniais, a "prohibition du mariage entre individus porteurs d'un même totem" (DURKHEIM, 1902, p. 83). Retomando seu estudo anterior sobre as regras de exogamia (1898), Durkheim analisa “l'obligation de se marier en dehors de la moitié à laquelle on appartenait" entre os Arunta (DURKHEIM, 1902, p. 108). No artigo subsequente, "Sur l'organisation matrimoniale des sociétés australiennes" (1905), ele continua a investigação do sistema de interdições matrimoniais australiano, explicitando "[1]a manière dont se contractent obligatoirement les mariages dans ces conditions" (DuRKHEIM, 1905, p. 123). Com efeito, Durkheim continua a privilegiar o estudo das regras de conduta obrigatórias, tomando as interdições como índices de manifestação de tais regras. Conforme esclarece numa nota do Année, Durkheim considera a exogamia "une pratique juridique [...] qui constitue l'instituition matrimoniale"; tomadas em conjunto, as regras exogâmicas formam "le système juridique de la societé considerée" 
(DURKHEIM, 1903, p. 305). Tal proposta se insere em seu projeto de uma sociologie morale et juridique, que considera que as regras morais mais fundamentais de uma sociedade se expressam nas fórmulas jurídicas. Em "La détermination du fait moral" (1906), Durkheim esclarece sua preferência: "Dans le droit, la plus grande partie de la morale domestique, de la morale contractuelle, de la morale des obligations, toutes les idées relatives aux grands devoirs fondamentaux viennent se traduire et se refléter" (DURKHEIM, 1906, p. 199; grifo nosso). É, portanto, precisamente a capacidade do direito de traduzir e tornar inteligíveis - i. e., transparentes - as regras morais que faz Durkheim considerá-lo uma via preferencial de acesso aos fenômenos da vida moral. Retomando a noção kantiana de dever, Durkheim afirma que a obrigação constitui "un des priemiers caractères de la règle morale" e, particularmente, seu "aspect abstrait" (DURKHEIM, 1906, p. 114). À diferença das regras que regem o mundo natural, em que a consequência dos eventos pode ser deduzida analiticamente a partir de seu próprio conteúdo, o caráter sintético das regras morais pode ser atestado, segundo Durkheim, pela existência de sanções. Em outros termos, é porque "la sanction est une conséquence de l'acte qui ne résulte pas du contenu de l'acte, mais de ce que l'acte n'est pas conforme à une règle préétablie" que, prossegue o autor, "nous sommes tenus de ne pas accomplir les actes qu'elles nous interdisent tout simplement parce qu'elles nous les interdisent. C'est ce qu'on appelle le caractère obligatoire de la règle morale" (DURKHEIM, 1906, p. 121). Em 1906, Durkheim reconhece que, até então, "il est vrai, nous n'avons considéré que les sanctions négatives" isto é, as penas, interdições e proibições, justamente "parce que le caractère obligatoire de la règle s'y manifeste plus clairement" (DURKHEIM, 1906, p. 121).

Como corolário dessa posição, Durkheim também vê com descrédito o domínio da estética, pois considera que os fenômenos estéticos e as emoções que eles provocam estariam na rota oposta àquela estabelecida pela sociologie morale et juridique. Em seu curso sobre a educação moral, ministrado na mesma época ${ }^{1}$, Durkheim afirma que o objetivo da arte é traduzir as impressões e emoções que ela produz por meio de "états tout idéaux", de maneira que “[t]oute oeuvre d'art est donc l'expression d'un idéal" (DuRKHEIM, 1925, p. 307). Todavia, a arte expressa essas emoções e impressões

1 L'éducation morale (1925) é baseado em um manuscrito não datado que, segundo Fauconnet, já havia sido preparado por Durkheim em Bourdeux, mas que só foi ministrado neste formato pela primeira vez já em Paris em 1902-1903, sendo repetido em 1906-1907. 
interiores por meio de imagens: ao contrário dos conceitos, que objetivam exprimir o real e afetar nossa razão, as imagens estéticas objetivam ultrapassar o real e afetar nossa imaginação e sensibilidade. Com efeito, o domínio da estética constitui "le domaine du rêve, de la fiction, des libres combinaisons mentales" (DURKHEIM, 1925, p. 311). Precisamente por essa razão, Durkheim sustenta haver um antagonismo entre arte e moral, na medida em que o mundo da moral diz respeito às ações no mundo real, ao passo que a arte nos desconecta da realidade e nos introduz a um mundo imaginário:

Le jeu et l'art nous font donc vivre également dans un monde d'images, que nous savons précisément tel, et ce sont ces combinaisons d'images qui font le plaisir du jeu, comme celui de l'art. En ce sens, on peut dire que l'art est un jeu. La morale, au contraire, est de la vie sérieuse. C'est même ce qu'il y a de plus sérieux, de plus grave dans la vie sérieuse. On voit toute la distance qu'il y a entre ces deux formes de l'activité : c'est toute la distance qui sépare le jeu du travail. Ce n'est donc pas en apprenant à jouer ce jeu spécial, qui est l'art, que nous pourrons apprendre à faire notre devoir (DURKHEIM, 1925, p. 313; grifo nosso).

Segundo o autor, a atividade moral estaria ligada ao que há de mais grave e real da vida social, como o trabalho, enquanto a atividade estética significa precisamente a fuga da realidade em direção ao prazer e à imaginação, como no caso da arte e do jogo. Nesse sentido, Durkheim enfatiza o dever como aquilo que constitui não só o núcleo da moral mas, igualmente, o da vida social, relegando ao segundo plano o domínio das artes e da imaginação. Para Durkheim, portanto, a divisão entre atividade moral e estética diz respeito, em última análise, à oposição entre o dever de la vie sérieuse e o deleite de la vie réjouissante, bem como da hierarquia que o autor estabelece da primeira em relação à segunda.

Contudo, ainda em "La détermination du fait moral", Durkheim faz o movimento explícito em direção a outro aspecto da moralidade, a saber: a noção de bem ou a desejabilidade dos fenômenos morais. Segundo o autor, se a noção de obrigação kantiana permitiu criticar o utilitarismo, a noção de bem, por sua vez, permitiria repensar a heterogeneidade kantiana entre sensibilidade e razão. Durkheim argumenta que existem noções, tais como a de sagrado, que manifestam essa mesma dualidade entre dever e desejo. Conforme afirma o autor: "L'être sacré, c'est, en un sens, l'être interdit, que l'on n'ose pas violer ; c'est aussi l'être bon, aimé, recherché" (DURKHEIM, 1906, p. 114). Dessa maneira, o fato do sagrado ser a noção que fundamenta também os fenômenos religiosos chama a atenção, sob um novo prisma, para a íntima relação entre 
religiosidade e moralidade: isto é, não mais com ênfase na obrigação, mas no seu caráter desejável. Notadamente, “c'est l'idée du Souverain Bien qui prédomine” nas sociedades em que "la morale est essentiellement religieuse" (DURKHEIM, 1906, p. 122). De acordo com o novo axioma de Durkheim: "plus un morale est essentiellement religieuse, plus aussi l'idée d'obligation est effacée” e, portanto, “[c]e n'est donc pas par son aspect obligatoire que la morale se rapproche le plus de la religion" (DURKHEIM, 1906, p. 184; grifo nosso). Não obstante, ainda que tal afirmação parecesse se endereçar apenas às sociedades elementares, Durkheim afirma que também na sociedade moderna a moral se apresentava "moins comme un code de devoirs, comme une discipline définie qui nous oblige, que comme un idéal entrevu, mais encore bien indéterminé, qui nous attire" (DURKHEIM, 1906, p. 183). Devido ao declínio da moral tradicional e ao consequente período de crise da sociedade moderna, Durkheim afirma que "la vie moralle actualler est toute pleine de religiosité", ainda que "[1] caractère sacré de la morale n'est pas tel qu'il doive la soustraire à la critique, comme il y soustrait la religion" (DURKHEIM, 1906, p. 126). Talvez o melhor exemplo moderno dessa tendência ao mesmo tempo religiosa e desejável da moral moderna esteja expresso na noção de pessoa humana, cujo caráter sagrado se expressa não apenas no respeito que ela gera, mas principalmente na simpatia e aspiração que temos por esse ideal moral moderno. Conforme argumenta Durkheim, a pessoa é "l'idéal que nous nous efforçons de réaliser en nous le plus complètement qu'il nous est possible" (DuRKHEIM, 1906, p. 125). Portanto, a noção de sagrado se torna a referência de Durkheim para investigar a moral do ponto de vista de seu caráter ideal e desejável. Apesar de reconhecer que a moral jamais se verá totalmente livre de seu caráter religioso, Durkheim não pretende hipostasiar a religiosidade, tal como as filosofias da religião espiritualistas o fizeram, a ponto de concebê-la como um ser transcendente. Ao contrário, Durkheim crê ser possível exprimir o sagrado por meio de uma linguagem racional e laica: "je m'oblige à la traduire [le sacré] en un langage rationnel, sans lui retirer, pourtant aucun de se caractères spécifiques" (DURKHEIM, 1906, p. 183-184; grifo nosso). De acordo com tal postulado, Durkheim oferece, pela primeira vez, uma definição da noção de sagrado como "ce qui est mis à part, ce qui est séparé" das coisas profanas (DURKHEIM, 1906, p. 184). 
Da mesma maneira, Durkheim passa a se interessar pela relação entre sociedade e divindade de maneira mais sistemática. No mesmo período, Durkheim ministra um curso acerca da emergência do culto da pessoa a partir das religiões teístas, dedicado a sustentar a tese de que God is Society. Conforme o resumo do curso, tal desenvolvimento não significa que deus tenha apenas deixado de existir para a humanidade, "it is rather humanity which discovers God in itself, and which does not for that reason adore him with any the less fervor" (LALANDE, 2006, p. 256). Se essa era uma possibilidade de fornecer uma base racional para a relação de conexão entre religião e moral, também é a partir dela que Durkheim vai pensar a sociedade não apenas no âmbito de seu conjunto de regras, mas como um ideal compartilhado por seus membros. God is Society na medida em que deus e sociedade podem ser tomados como ideais transmutáveis entre si. Da mesma maneira, o ideal de pessoa resulta das transformações simbólicas do ideal de sociedade, pois mantém o mesmo sentimento de respeito e admiração dirigido aos deuses. Conforme afirma: “je ne vois dans la divinité que la société transfigurée et pensée symboliquement" (DURKHEIM, 1906, p. 129; grifo nosso). Com efeito, a sociedade é caracterizada como um conjunto de ideais que simbolizam determinada "force sui generis, force intense", que nada mais é que a "force collective" (DURKHEIM, 1906, p. 132). Segundo o autor:

Une société, c'est un foyer intense d'activité intellectuelle et morale et dont le rayonnement s'étend au loin. Des actions et des réactions qui s'échangent entre les individus se dégage une vie mentale, entièrement nouvelle, qui transporte nos consciences dans un monde dont nous n'aurions aucune idée, si nous vivions isolés. Nous nous en apercevons bien aux époques de crises, quand quelque grand mouvement collectif nous saisit, nous soulève au dessus de nous-mêmes, nous transfigure (DURKHEIM, 1906, p. 135-136; grifo nosso).

Dessa maneira, Durkheim concebe a sociedade como um feixe intenso de forças que, uma vez concentradas, transfiguram o meio social e criam uma realidade sui generis. Tal poder da coletividade seria particularmente visível na sociedade moderna quando dos períodos de crise, durante os quais o poder da ação coletiva toma o primeiro plano da vida social e pode, assim, ser percebido pelos próprios indivíduos.

No ano letivo de 1906-1907, Durkheim ministra o curso intitulado "La religion les origines", e é o momento em que o problema do totemismo como religião primitiva passa a ser o foco de sua análise. O curso também pode ser considerado uma primeira 
versão de Les formes élémentaires de la vie religieuse ${ }^{2}$. Transcrito e publicado em 1907, o curso objetiva realizar as definições de religião e do totemismo como religião primitiva, seguidas de uma breve discussão acerca das ideias e práticas do totemismo australiano. Em primeiro lugar, Durkheim examina o problema da origem da religião nas matrizes teóricas que julga serem as mais importantes, a saber: a teoria animista de Edward Tylor e a naturista de Friedrich Max Müller. O cerne da crítica de Durkheim reside na tentativa comum de tentar derivar "la notion du sacré de choses données dans l'expérience immédiate et qui se présentent d'abord comme purement profanes" (FonTANA, 1907, p. 538). Tal estratégia leva à conclusão de que de a religião seria ou uma ilusão da imaginação - versão animista de Tylor -, ou uma doença da linguagem versão naturista de Max Müller. Tanto num caso quanto no outro, portanto, "la religion n'est plus alors qu'un système d'idées hallucinatoires et fausses, un rêve vécu, dont on ne saurait concevoir qu'il ait si longtemps duré qu'en voyant dans sa permanence l'effet voulu d'une habile politique sacerdotale" (FONTANA, 1907, p. 539). Reconhecendo a impossibilidade de considerar as religiões simples alucinações a serviço da dominação sacerdotal, Durkheim procura estabelecer uma definição de fenômeno religioso que, partindo dos mesmos termos, possa abrir um novo caminho de investigação. Na nova versão que fornece, Durkheim parte do princípio de que a "notion de faits religieux suppose à sa base une classification des choses en deux groupes : le sacré et le profane" (FONTANA, 1907, p. 531); seguindo sua definição anterior, ele afirma que "le sacré ne se définit que par son opposition avec le profane" (FONTANA, 1907, p. 532). Na base da noção de fenômeno religioso estaria um sistema binário de classificação, cujos elementos são radicalmente heterogêneos e se definem por oposição. É a partir dessa oposição que se desenvolvem as interdições que marcam o caráter sagrado das coisas religiosas, por exemplo. Durkheim, contudo, reclama a necessidade não apenas de uma definição do conjunto dos fenômenos religiosos, mas de uma definição de religião propriamente dita, com ênfase precisamente no que distingue a última da magia. Parafraseando Hubert e Mauss (1904), Durkheim afirma que a magia é, essencialmente, antirreligiosa; mas, à diferença deles, Durkheim lança mão de outro recurso para marcar a distinção, a saber, a capacidade da religião formar uma igreja:

2 Para uma comparação entre a estrutura do curso de 1906-1907 e da obra de 1912 de Durkheim, cf. Watts Miller (2012a, p. 101). 
Il est un caractère par lequel elles se distinguent très nettement : les croyances religieuses sont communes aux membres d'une collectivité qui font profession d'y adhérer ; une société dont les membres sont liés les uns aux autres parce qu'ils se représentent de la même manière les choses sacrées dans leurs rapports avec les choses profanes, c'est ce que nous appelons une église, et il n'y a pas de religion sans église (FONTANA, 1907, p. 532).

No trecho acima, Durkheim define igreja como uma comunidade cujos membros são vinculados uns aos outros por compartilharem o mesmo critério de classificação das coisas entre sagradas e profanas. Uma definição que, portanto, recoloca o problema da religião como uma comunidade moral. No entanto, à diferença da comunidade moral outrora definida pelo caráter obrigatório das regras de conduta sancionadas, Durkheim agora define essa comunidade em termos do caráter sagrado dos ideais coletivos. De acordo com a sua nova definição, a religião consiste em "un système de croyances et de pratiques relatives à des choses sacrées - croyances et pratiques communes à une collectivité déterminée" (FONTANA, 1907, p. 533).

Ao contrário das explicações meramente hipotéticas sobre a origem da religião, a que Durkheim desenvolve tem por base a religião considerada mais primitiva e melhor documentada até aquele momento, isto é, o totemismo australiano. Tal proposta pretende sublinhar não o que há de específico ou arcaico na religião australiana, mas antes explicar a natureza da religião em geral e o desenvolvimento de certas ideias religiosas fundamentais ao longo do processo de secularização. De maneira geral, o totemismo refere-se à ação coletiva de um grupo que se distingue e se define pela relação com um totem, isto é, uma determinada classe de animais ou plantas que empresta o nome aos membros do clã. Do ponto de vista de Durkheim, importa mostrar como o totem constitui o princípio de classificação das coisas sagradas e profanas para o clã e é, portanto, o centro de sua religião. Mais do que simplesmente emprestar o nome, Durkheim afirma que o totem consiste em uma espécie de emblema sagrado do clã, cuja representação pictórica é reproduzida em corpos e objetos para finalidades religiosas. Dessa maneira, o estudo "des représentations figuratives des totems fournit déjà, à cet égard, des indications instructives" (FonTANA, 1907, p. 95). O totemismo é caracterizado, então, pelas formas de expressão estética, que representam de "manière purement symbolique l'être qui lui sert de totem" e produzem, por essa razão, “impressions esthétiques, et non pas seulement religieuses" (FoNTANA, 1907, p. 95, n. 
3). O caso mais importante é, sem dúvida, o da churinga, o objeto sagrado "qui portent l'image du totem" (FONTANA, 1907, p. 94), separado e protegido do contato profano de não-iniciados. A centralidade da churinga leva Durkheim, então, a concluir que são as representações figuradas do totem "et non les êtres dont elles sont les symboles, qui sont la source éminente de la religiosité" (FonTANA, 1907, p. 96). Nesse sentido, tanto os animais quanto os membros do clã são considerados sagrados na medida em partilham da natureza do totem e se consideram, por essa razão, congêneres uns dos outros. Conforme comenta o autor:

ce [le totémisme] n'est pas un culte idolâtrique d'animaux ou de plantes, puisque déjà nous avons trouvé trois catégories d'êtres possédant un caractère sacré : les représentations figurées du totem, les êtres totémiques eux-mêmes, et les membres du clan. [...] pour le primitif, tout ce qui peuple l'univers fait partie en quelque façon de la société ; la tribu comprend, non pas seulement les clans, mais aussi tout ce qui existe ; et de même que les hommes de la tribu sont répartis en clans, de même les différentes espèces de choses sont rattachées à des clans déterminés. L'univers tout entier prend ainsi un caractère religieux. En effet, nous avons vu que l'homme du clan du corbeau, par exemple, a quelque chose de la nature du corbeau ; qu'il est, en quelque façon, un corbeau. De même, les choses qui sont classées avec lui, dans le même clan, sont conçues elles aussi comme des corbeaux ; la grêle et l'hiver sont des modalités du corbeau (FONTANA, 1907, p. 98; grifo nosso).

Assim, o totemismo é uma religião na medida em que as representações figuradas do totem funcionam como princípio de classificação de todas as coisas do universo entre sagradas ou profanas, de acordo com a relação de parentesco com o totem. Além disso, todas as coisas que partilham da natureza sagrada do totem são compreendidas como variações de forma dessa mesma natureza e podem, portanto, se transfigurar umas nas outras. Conforme o exemplo do clã do corvo, ao partilhar algo da natureza do totem corvo, o membro do clã pode se tornar, também, corvo.

Se os símbolos totêmicos são considerados mais sagrados que os próprios animais e plantas representados, isso indica que o caráter sagrado não advém da natureza ou das características intrínsecas desses seres. Durkheim se pergunta, então, que princípio estaria na base dessa religiosidade e formaria a unidade do culto para além da diversidade dos totens. Segundo o autor, todos esses seres totêmicos são apenas encarnações temporárias de uma força anônima e impessoal, que é independente das coisas consideradas sagradas e as precede: nesse sentido, "le totem n'est que la forme 
sensible sous laquelle le primitif se représente cette force anonyme et impersonnelle" (FONTANA, 1907, p. 105). Não obstante, essa força sui generis não é particular aos australianos e é, antes, encontrada em diversas outras sociedades indígenas, cujo exemplo mais conhecido é expresso na noção melanésia de mana. Parafraseando um comentário indígena sobre a consubstancialidade entre as coisas chamadas mana, Durkheim exemplifica: "les hommes, les oiseaux, les animaux, disait-il vont et viennent par toute la terre ; mais il y a des points où ils s'arrêtent et se posent; de même fait le vakanta : les dieux, peut-on dire, ce sont les points où cette force a stationné" (FonTANA, 1907, p. 105). Por conseguinte, tal noção de força contém em germe concepções ulteriores tanto religiosas, como a de divindade, quanto laicas, como a de causalidade (FONTANA, 1907, p. 106-107). Resta saber, então, as causas que engendram essa força e que fundamentam o totemismo. Se, como vimos, a imagem totêmica simboliza tanto a divindade quanto o próprio clã, é porque a divindade totêmica não é outra coisa senão "la société elle-même, mais sublimée, hypostasiée, en quelque sorte" (FONTANA, 1907, p. 107). Nesse sentido, a sociedade aparece como uma força intensa e estimulante que tem o poder de "créer du sacré" (FONTANA, 1907, p. 108). Isso é particularmente visível no caso australiano, em que os clãs alternam entre períodos de dispersão, associados às coisas ordinárias, isoladas e profanas; e períodos de concentração, durante os quais "l'influence exaltante exercée par les réunions en foule se fait-elle sentir chez lui à un degré extraordinaire" (FONTANA, 1907, p. 109) alternância que conforma o mundo das coisas comunais e sagradas dos australianos. Nessas cerimônias totêmicas, em que predominam "des danses, des jeux", bem como “des sentiments de joie, d'expansion confiante", os totens são, portanto, a expressão figurada da força social do clã (FONTANA, 1907, p. 110).

Além da noção de força sui generis, o totemismo também é composto por crenças e ritos que não só "se complèment et s'expliquent", mas que contém “en germe les religions ultérieures" (FONTANA, 1907, p. 628). Quanto às crenças australianas, a noção de alma é uma das mais características manifestações do princípio totêmico, representada primordialmente sob a forma animal e exterior aos membros do clã. Nesse sentido, Durkheim considera a noção de alma australiana um fragmento da divindade totêmica, em que "le principe totémique incarné dans chaque individu et s'individua lisent en lui" (FonTANA, 1907, p. 623). Para o autor, a alma seria o elemento sagrado 
que é adicionado ao organismo considerado profano, formando a ideia de uma dupla natureza humana: "l'homme est un être double, portant en lui deux natures qui s'opposent comme le profane et le sacré" (FonTANA, 1907, p. 624). No entanto, a emanação do princípio totêmico como alma engendra, por um lado, a natureza sagrada das pessoas do clã; por outro lado, a alma totêmica está na origem do processo de individualização e autonomização do sagrado para além dos limites do clã, produzindo seres espirituais individuais que antecedem a conformação do grande deus australiano. Assim, Durkheim se opõe àqueles que pensam que a ideia de deus teria sido importada dos europeus pelos indígenas australianos, uma vez que tal concepção lhes pareceu “d'une théologie tellement haute, qu'ils ont refusé d'y voir une création indigène"; ao contrário, sustenta que "les croyances totémiques devaient trouver leur aboutissement logique dans cette notion d'un grand dieu" (FonTANA, 1907, p. 627). Quanto aos ritos, Durkheim os subdivide em negativos e positivos, e propõe estudá-los separadamente. Os ritos negativos nada mais são que as proibições, tabus ou interdições rituais que têm por objetivo manter a separação radical das coisas sagradas em relação às profanas. A esse respeito, Durkheim cita uma série de interdições que proíbem o contato com a churinga, o tabu alimentar, o sabá judaico e a enunciação de nomes sagrados. Nesses e em outros exemplos, as interdições visam, sobretudo, garantir que "le théâtre de la vie religieuse et celui de la vie profane doivent être absolument distincts" (FONTANA, 1907, p. 630). Isso se deve ao fato de que as forças religiosas apresentam um alto grau de contagiosidade: "elles sont dans un état de tension tel, qu'elles cherchent toujours à sortir des choses dans lesquelles elles résident pour se communiquer à tout ce qui se trouve à leur portée" (FONTANA, 1907, p. 632). A manipulação do sagrado por parte dos membros do clã é sempre perigosa e demanda, por essa razão, um preparo especial por parte daqueles engajados nessa tarefa, que nada mais é que a observância rigorosa das interdições rituais. Dessa maneira, as interdições advém da necessidade de proteger os membros do clã não preparados - profanos - das consequências geralmente letais que o contato indevido com o sagrado acarreta. Conforme conclui Durkheim: "Ainsi, la contagiosité des forces religieuses est l'origine des interdits" (FONTANA, 1907, p. 633).

Já os ritos positivos são aqueles destinados a colocar os iniciados em contato com o sagrado, cujo caso paradigmático é o intichiuma australiano. Segundo Durkheim, a “consomation du totem" pelos membros do clã "domine toutes ces pratiques" 
(FONTANA, 1907, p. 634). Nesse sentido, a comensalidade da espécie totêmica é "le moyen pour l'individu de revivifier en lui cette force" e, portanto, "[1]à est l'origine de la communion, qui permet de manger, à certains moments et dans certaines conditions, ce à quoi il n'est pas permis de toucher en temps ordinaire" (FONTANA, 1907, p. 635). Essa breve caracterização do intichiuma em termos de uma refeição totêmica comunal remete a investigação do totemismo australiano à teoria do sacrifício de Robertson Smith. Ainda que de maneira breve, Durkheim retoma Smith para discutir o sacrifício como uma oferta ou oblação dos homens à divindade e, ao mesmo tempo, uma responsabilidade divina de alimentar os homens. Apesar de Smith rejeitar essa possibilidade, Durkheim crê que ela ocorria já nas cerimônias totêmicas australianas:

Robertson Smith trouve qu'il est absurde de dire en même temps que la fonction des dieux était de nourrir les hommes et que le sacrifice était une offrande alimentaire à la divinité. [...] Il fait remarquer, en effet, que le cercle vicieux signalé par R. Smith a bien été commis dès l'origine ; nous l'avons en somme trouvé dans la cérémonie qui a été décrite plus haut, et qui nous montrait que l'espèce animale ne peut vivre que si l'homme renouvelle sa vie et, d'autre part, l'homme continue lui-même de vivre en se nourrissant, à certains moments, de cette espèce. En somme, l'homme donne aux dieux ce qu'il reçoit d'eux, à savoir la vie. [...] Le sacrifice est donc fait de deux éléments : la communion et l'oblation; ces deux éléments, successifs dans l'intichiouma, sont simultanés dans le sacrifice proprement dit. Aussi le sacrifice est-il l'élément de toute religion, puisqu'il entretient la vie des dieux dont dépend celle des hommes et l'existence des choses (FONTANA, 1907, p. 635-636).

De acordo com o trecho acima, Durkheim explica o intichiuma australiano como uma cerimônia sacrificial que, desde o início, estabelece uma relação de interdependência e reciprocidade entre homens e deuses. Tal interdependência torna essas cerimônias religiosas regulares e periódicas, distinguindo-as das cerimônias mágicas ocasionais (FONTANA, 1907, p. 636). Na visão de Durkheim, a explicação genealógica do intichiuma como sacrifício permitira explicar a evolução do culto positivo desde o totemismo até as religiões idealistas. Tendo em vista que Hubert e Mauss (1899) consideravam o sacrifício um fenômeno demasiado complexo e relativamente tardio no âmbito da evolução religiosa, só restava a Durkheim voltar ao teórico que concebeu o sacrifício como fenômeno central do totemismo e da religião em geral. Apesar de jamais ter citado a obra de Smith relativa à religião antes de 1907, Durkheim responde, em sua famosa carta à Simon Deploige, que sua reflexão acerca da religião como "la matrice 
des idées morales, juridiques etc" nada tem a ver com Wilhelm Wundt e, antes, "[i]1 était dû tout entier aux études d'histoire religieuse que je venais d'entreprendre et notamment à la lecture des travaux de Robertson Smith et de son école" (DEPLOIGE; DURKHEIM, 1907, p. 613). No entanto, a resposta de Deploige, raramente citada, já questionava a versão de Durkheim acerca de sua própria evolução teórica:

Le fait que cette suggestion de M. Wundt est demeurée, pendant huit ans, à l'état de virtualité, dans les régions obscures de la subconscience, et qu'elle a émergé seulement au clair soleil de la conscience après l'intervention de M. Smith, - ce fait peut être utile pour documenter le psychologue qui ferait une étude de la mentalité de M. Durkheim. Mais il est insignifiant a notre point de vue. D'abord parce que notre recherche se préoccupe de la formation du système considéré objectivement et non de la germination des idées dans le cerveau de l'auteur. Ensuite parce que cette recherche est limitée à la conception sociologique de $\mathrm{M}$. Durkheim dont elle envisage surtout la méthode. - Quand M. Durkheim aura livré à la publicité ses travaux d'histoire religieuse, celui qui en entreprendra l'examen, fera peut-être bien au surplus d'instituer des rapprochements non seulement avec les études de R. Smith, mais encore avec celles de Jevons, de Tylor, de Lang, de Frazer, de Hartland (DEPLOIGE; DuRKHEIM, 1907, p. 619; grifo nosso).

A respeito da suposta revelação de Durkheim, a resposta de Deploige indica, já na época, dois problemas difíceis de contornar. O primeiro e mais evidente é que Durkheim não havia publicado nenhum trabalho sobre Smith e a história das religiões britânica antes de 1907. Conforme sugere Deploige, no momento em que Durkheim chegasse a publicar esses trabalhos, aí sim alguém poderia avaliar, objetivamente, em que medida suas contribuições se devem ou não a Smith e aos demais autores britânicos. O segundo problema, decorrente do primeiro, é a tentativa de negar a análise objetiva de textos publicados por Durkheim em favor de uma análise subjetiva do processo de maturação de suas ideias sobre a religião. Em princípio, Durkheim alega que a motivação das suas cartas é esclarecer "graves et certaines erreurs" da interpretação de Deploige (DePloige; DuRKhEIM, 1907, p. 607); mas ao invés de oferecer uma interpretação alternativa de seus próprios escritos, Durkheim apresenta uma narrativa pessoal sobre "ce changement d'orientation" oriunda da leitura da obra de Smith, sem mencionar nenhum texto publicado ao longo dos últimos 12 anos que atestasse essa radical mudança a respeito da religião ocorrida desde 1895. Ao contrário, se houve um ponto de inflexão no pensamento de Durkheim sobre a religião, esse período é o mesmo da 
escrita da carta a Deploige e do curso sobre a origem da religião ministrado em 19061907.

Em 1909, Durkheim publica dois artigos advindos de seu livro em preparação, intitulado provisoriamente como Les formes élémentaires de la pensée et de la vie religieuse. Os artigos dizem respeito a excertos da introdução (1909a) e do Livro I (1909b) da edição completa publicada em 1912. Mantendo o foco nos problemas relativos às ideias religiosas e à teoria do conhecimento, Durkheim argumenta que a proposta de seu novo projeto é desvelar, por meio do estudo da religião primitiva, a natureza religiosa perene da humanidade. Além disso, Durkheim acredita haver uma vantagem na pesquisa das sociedades elementares, uma vez que seus fenômenos religiosos manifestam ao observador de maneira imediata aquilo que eles têm de elementar - opondo-se, portanto, à composição intrincada dos fenômenos modernos, que se apresentam em camadas de interpretação que muitas vezes os deformam e ocultam suas causas. Por essa razão, Durkheim afirma que a observação etnográfica é responsável por "véritables révélations qui ont complètement rénové l'étude des institutions humaines", bem como provocou na sociologia "les plus fécondes révolutions" (DURKHEIM, 1909a, p. 739). Diferentemente do que afirmara anteriormente, Durkheim agora considera que mesmo "[1]es rites les plus barbares ou les plus bizarres, les mythes les plus étranges traduisent quelque besoin humain, quelque aspect de la vie soit individuelle soit sociale", e cabe à sociologia revelar a realidade subjacente que esses símbolos religiosos figuram (DURKHEIM, 1909a, p. 734). Nos rituais elementares, os ritos e os mitos formam uma unidade de análise, em que "le rite n'est rien autre chose que le mythe mis en action" (DURKHEIM, 1909b, p. 155). A esse repeito, Durkheim destaca que os rituais periódicos celebrados pelas sociedades australianas consistem em "représentations dramatiques où sont mimés les actes que les mythes attribuent à ces héros légendaires" (DURKHEIM, 1909b, p. 20; grifo nosso). Além da relação mimética entre mito e rito, Durkheim observa duas características do pensamento indígena que o distinguem do pensamento moderno. Em primeiro lugar, os indígenas não distinguem os diferentes reinos da natureza, e tampouco estabelecem "les barrières presque infranchissables que notre éducation moderne nous a habitués à y voir"; ao contrário, o indígena "admet sans résistance aucune que le minéral peut se transmuter en végétal ou en animal, celui-ci en homme, ou inversement" (DURKHEIM, 
1909b, p. 26; grifo nosso). Em segundo, à diferença do antropomorfísmo moderno, o pensamento indígena não faz do reino humano um protótipo para os demais reinos e, antes, o considera imiscuído nos demais reinos da natureza sem qualquer preponderância. Apesar dos contrastes entre as ideias indígenas e modernas, tais características levam Durkheim a reconhecer que o chamado princípio de identidade, fundamento do pensamento científico, estaria também na base do pensamento indígena. Da mesma maneira, a mitologia indígena constituiria um tipo de pensamento axiomático, em que "la partie vaut le tout" (DuRKHEIM, 1909a, p. 746). Durkheim elenca uma série de noções, como a de gênero, força e causalidade, que também poderiam ser investigadas as condições de seu desenvolvimento nas mais distintas sociedades, mas se detém nas noções de tempo e espaço - previamente estudadas por Hubert e Mauss. Seguindo esses autores, Durkheim salienta como tempo e espaço são categorias coletivas particularmente relevantes para a análise dos fenômenos religiosos, que organizam desde a distribuição espacial dos grupos até ritmo da vida coletiva (DURKHEIM, 1909a, p. 744-746). Isso tudo demonstra como o estudo dos fenômenos religiosos elementares ultrapassa o domínio estrito das ideias religiosas e implica uma série de juízos que organizam a vida intelectual em geral. Conforme conclui Durkheim, a religião "ne s'est pas bornée à enrichir un esprit humain, préalablement formé, d'idées toutes faites ; elle a contribué à former l'esprit lui-même" (DURKHEIM, 1909a, p. 742; grifo nosso).

Ainda considerando a contribuição dos fenômenos religiosos para a formação do espírito humano, Durkheim discute o problema da origem dos valores em seu artigo de 1911, “Jugements de valeur et jugements de réalité”. Segundo o autor, o valor atribuído aos objetos não advém de nenhum atributo que lhe seja intrínseco mas, antes, de uma realidade sui generis exterior. Retomando o esquema kantiano, Durkheim considera que o homem possui a faculdade de representar as coisas que é, ao mesmo tempo, distinta e além da experiência: isto é, a capacidade de criar ideais e utilizá-los como medida para postular o valor das coisas. Nesse sentido, os objetos da experiência têm valor quando estes "expriment, reflètent, à un titre quelconque, un aspect de l'idéal" (DURKHEIM, 1911, p. 444). A questão que se coloca, então, é a do locus de criação de ideais. Durkheim sustenta que os ideais têm uma origem coletiva, pois são fruto de uma nova vida psíquica e de sentimentos tão intensos quanto qualitativamente distintos que se 
desenvolvem somente no interior de grupos, desencadeando ações puramente coletivas em torno de fins ideais. "Entraîné par la collectivité, l'individu se désintéresse de luimême, s'oublie, se donne tout entier aux fins communes" (DURKHEIM, 1911, p. 447). Esses momentos puramente coletivos, excepcionais e efêmeros, são justamente aqueles de efervescência coletiva, considerados por Durkheim o locus de criação dos grandes ideais sociais:

C'est, en effet, dans des moments d'effervescence de ce genre que se sont, de tout temps, constitués les grands idéaux sur lesquels reposent les civilisations. Les périodes créatrices ou novatrices sont précisément celles où, sous l'influence de circonstances diverses, les hommes sont amenés à se rapprocher plus intimement, où les réunions, les assemblées sont plus fréquentes, les relations plus suivies, les échanges d'idées plus actifs : c'est la grande crise chrétienne, c'est le mouvement d'enthousiasme collectif qui, aux $\mathrm{XII}^{\mathrm{e}}$ et $\mathrm{XIII}^{\mathrm{e}}$ siècles, entraine vers Paris la population studieuse de l'Europe et donne naissance à la scolastique, c'est la Réforme et la Renaissance, c'est l'époque révolutionnaire, ce sont les grandes agitations socialistes du $\mathrm{XIX}^{\mathrm{e}}$ siècle. [...] L'idéal tend alors à ne faire qu'un avec le réel ; c'est pourquoi les hommes ont l'impression que les temps sont tout proches où il deviendra la réalité elle-même et où le royaume de Dieu se réalisera sur cette terre. [...] Certes, ces idéaux s'étioleraient vite, s'ils n'étaient périodiquement revivifiés. C'est à quoi servent les fêtes, les cérémonies publiques, ou religieuses, ou lä̈ques, les prédications de toute sorte, celles de l'Église ou celles de l'école, les représentations dramatiques, les manifestations artistiques, en un mot tout ce qui peut rapprocher les hommes et les faire communier dans une même vie intellectuelle et morale. Ce sont comme des renaissances partielles et affaiblies de l'effervescence des époques créatrices (DURKHEIM, 1911, p. 448-449; grifo nosso).

No trecho de 1911, Durkheim emprega pela primeira vez a noção de efervescência coletiva como fenômeno de origem religiosa que é, ao mesmo tempo, sinônimo da ação coletiva. Em consonância com os trabalhos prévios de Hubert e Mauss, Durkheim sustenta que são os períodos de efervescência os responsáveis pela criação dos grandes ideais que caracterizam as civilizações, exemplificando tal afirmação com o relato de um conjunto de eventos religiosos e seculares que conformaram o desenvolvimento das civilizações europeias entre os séculos XII e XIX. Durante essas datas críticas, a suspensão da vida ordinária e dos interesses particulares arrasta os indivíduos para crenças e práticas puramente coletivas e propicia, excepcionalmente, a fusão entre ideal e realidade. Não obstante, os novos ideais demandam cerimônias periódicas de comunhão e rememoração por meio de representações dramáticas que visam reviver a efervescência das épocas criadoras. 
Concebidos dessa maneira, os ideais são muito mais que abstrações intelectualistas: são, antes, forças coletivas que recombinam elementos extraídos da realidade para justamente transcendê-la. Portanto, "la pensée collective métamorphose tout ce qu'elle touche" (DURKHEIM, 1911, p. 451; grifo nosso), na medida em que substitui o mundo dos sentidos por um mundo ideal. Retomando o problema dos juízos de fato e de valor, Durkheim admite que ambas operações lógicas são baseadas em ideais, mas de espécies distintas. Enquanto os juízos de fato objetivam exprimir o mais fielmente possível a realidade por meio de conceitos, os juízos de valor objetivam transfigurar a realidade subjacente em ideais de valor. Conforme o autor:

Si tout jugement met en œuvre des idéaux, ceux-ci sont d'espèces différentes. Il en est donc le rôle est uniquement d'exprimer les réalités auxquelles ils s'appliquent, de les exprimer telles qu'elles sont. Ce sont les concepts proprement dits. Il en est d'autres, au contraire, dont la fonction est de transfigurer les réalités auxquelles ils sont rapportés. Ce sont les idéaux de valeur. Dans le premier cas, c'est l'idéal qui sert de symbole à la chose de manière à la rendre assimilable à la pensée. Dans le second, c'est la chose qui sert de symbole à l'idéal et qui le rend représentable aux différents esprits. Naturellement, les jugements diffèrent selon les idéaux qu'ils emploient. Les premiers se bornent à analyser la réalité et à la traduire aussi fidèlement que possible. Les seconds, au contraire, disent l'aspect nouveau dont elle s'enrichit sous l'action de l'idéal (DURKHEIM, 1911, p. 451-452; grifo nosso).

Assim, apesar das semelhanças, juízos de fato e juízos de valor diferem no arranjo de seus elementos e, consequentemente, em suas funções. Nos juízos de fato, como os ideais traduzem de maneira fiel ou transparente as coisas do mundo, os conceitos nada mais são que símbolos transparentes mais facilmente assimiláveis para o pensamento dessas coisas. Nos juízos de valor, ao contrário, são as coisas que servem de símbolo para os ideais e os tornam representáveis para o pensamento; consequentemente, os ideais de valor transfiguram a realidade e a enriquecem com novas perspectivas oferecidas por sua ação no mundo. Nesse sentido, Durkheim sustenta que os fenômenos sociais consistem precisamente em sistemas de valores, e que é no domínio dos ideais que reside o objeto da sociologia. A sociologia, portanto, se limitaria a investigar os ideais, ou seja, a produzir juízos de fato por meio da tradução dos ideais coletivos em conceitos.

Em 1912, Durkheim publica Les formes élémentaires de la vie religieuse, obra que sintetiza as transformações de seu pensamento ao longo desse período. A esse respeito, ao contrário do que sustentara em seu artigo de 1902, Durkheim reconhece que as 
interdições alimentares e matrimoniais não são signos característicos do totemismo e seriam, antes, seus produtos indiretos (DURKHEIM, 1912, p. 154-155). Considerando que as ideias religiosas fundamentam a organização familiar primitiva, agora o autor sustenta que é preciso estudar o totemismo como religião antes de estudá-lo como grupo familiar (DURKHEIM, 1912, p. 148, n. 2). Tomando o totemismo australiano como objeto da pesquisa, Durkheim investiga a origem e a evolução das crenças e práticas religiosas australianas a partir de uma análise cruzada das etnografias de Spencer e Gillen e de Strehlow - oferecendo, ainda, fatos complementares acerca das sociedades indígenas norte-americanas. Não obstante, o estudo centrado nos povos australianos se inscreve em seu projeto mais amplo de demonstrar, “dans l'ordre pratique, l'irréductibilité de l'idéal moral au mobile utilitaire, et, dans l'ordre de la pensée, l'irréductibilité de la raison à l'expérience individuelle" (DURKHEIM, 1912, p. 23).

\subsection{Gênese e desenvolvimento das ideias religiosas elementares}

Após ter definido o totemismo australiano como religião elementar no Livro I de Les formes élémentaires de la vie religieuse, o objetivo de Durkheim no Livro II é analisar as crenças religiosas elementares e explicar sua origem. Durkheim retoma, então, sua análise do totem como emblema sagrado do clã: isto é, em que humanos, espécie totêmica e artefatos do clã são considerados sagrados na medida em que partilham da mesma representação figurada do totem - considerada ela mesma o protótipo das coisas sagradas. Com efeito, "[1]es représentations du totem ont donc une efficacité plus active que le totem lui-même" (DurkheIM, 1912, p. 189). Segundo o autor, as representações figuradas elementares não consistem em imagens fiéis à espécie totêmica, mas são, antes, grafismos ou desenhos abstratos, expressos nas pinturas corporais e nos objetos do clã, como a churinga. Como a sacralidade e os sentimentos de temor gerados pelas representações figuradas não advêm de nenhuma propriedade intrínseca aos seres e objetos totêmicos, Durkheim argumenta que ela só pode se originar de um princípio que é comum a todos eles, a saber, uma força anônima e impessoal, abstrata, imanente e difusa, que o australiano representa alegoricamente a partir de imagens sensíveis tomadas dos reinos animal e vegetal. Retomando o exemplo da fratria do corvo, Durkheim acrescenta que todos os membros da fratria se consideram corvos na medida em que "en eux tous se trouve un principe, qui constitue ce qu'ils ont 
de plus essentiel, qui leur est commun avec les animaux du même nom, et qui est pensé sous la forme extérieure du corbeau" (DURKHEIM, 1912, p. 270). Valendo-se da noção de mana, considerada o germe do pensamento mágico-religioso, Durkheim nomeia como mana totêmico essa força anônima e impessoal representada pelas figurações totêmicas (DuRKhEIM, 1912, p. 293). Com efeito, essas figurações totêmicas estão na base de todo um sistema de classificação das coisas entre sagradas e profanas, no qual cada clã divide as coisas entre aquelas aparentadas ao totem e, portanto, sagradas, e as demais coisas profanas. Reunidos todos os clãs, o totemismo australiano produz uma representação sistemática do mundo ou uma cosmologia, que se estende até o limite do universo conhecido. Nesse sentido, o totemismo australiano seria comparável ao politeísmo grego, pois “" $[\mathrm{t}]$ out comme la religion grecque, elle [la religion totémique] met du divin partout" (DURKHEIM, 1912, p. 220). Durkheim acredita que a organização religiosa do clã australiano seria comparável à do genos grego, tendo em vista que cada um goza de relativa independência e descentralização de culto. Além disso, todos esses cultos particulares seriam solidários uns aos outros e, por essa razão, o totemismo australiano consistiria num sistema religioso complexo formado pela reunião dos cultos de cada clã, "tout comme le polythéisme grec était constitué par la réunion de tous les cultes particuliers qui s'adressaient aux différentes divinités" (DURKHEIM, 1912, p. 222). Tal como a religião grega, o totemismo australiano é considerado por Durkheim "une religion fédérative qui ne peut dépasser un certain degré de centralisation sans cesser d'être elle-même" (DURKHEIM, 1912, p. 281; grifo nosso).

Feita a caracterização do totemismo australiano, Durkheim propõe investigar a gênese do mana totêmico e explicar a relação entre este princípio e as figurações totêmicas. Sua estratégia consiste, então, em retomar a etnografia de Spencer e Gillen (1904), e analisar a descrição das cerimônias religiosas desses povos oferecida pelos etnógrafos britânicos, selecionando os trechos considerados chave e oferecendo uma reinterpretação dos mesmos. Primeiramente, Durkheim afirma que os povos australianos dividem o tempo em duas fases distintas e alternantes entre si: uma de dispersão, ligada ao período das atividades cotidianas e ordinárias, e outra de concentração, ligada ao período das cerimônias religiosas extraordinárias, conformando uma espécie de calendário elementar australiano. Tal asserção seria corroborada por 
uma citação indireta de Spencer e Gillen, parafraseada por Durkheim da seguinte maneira:

\section{Spencer e Gillen}

From the moment of his initiation, however, his life is sharply marked out into two parts. He has first of all what we may speak of as the ordinary life, common to all the men and women, and associated with the procuring of food and the performance of corrobborees, the peaceful monotony of this part of his life being broken every now and again by the excitement of a fight. On the other hand, he has what gradually becomes of greater and greater importance to him, and that is the portion of his life devoted to matters of a sacred or secret nature. As he grows older he takes an increasing share in these, until finally this side of his life occupies by far the greater part of his thoughts (SPENCER; GILLEN, 1904, p. 33; grifo nosso).

\section{Durkheim}

La vie des sociétés australiennes passe alternativement par deux phases différentes. Tantôt la population est dispersée par petits groupes qui vaquent, indépendamment les uns des autres, à leurs occupations ; chaque famille vit alors de son côté, chassant, pêchant, cherchant en un mot, à se procurer la nourriture indispensable par tous les moyens dont elle dispose. Tantôt, au contraire, la population se concentre et se condense, pour un temps qui varie de plusieurs jours à plusieurs mois, sur des points déterminés. Cette concentration a eu lieu quand un clan ou une portion de tribu est convoqué dans ses assises et que, à cette occasion, on célèbre une cérémonie religieuse ou qu'on tient ce qu'on appelle, dans le langage usuel de l'ethnographie, un corrobbori (DURKHEIM, 1912, p. 307; grifo nosso).

Ao compararmos o trecho original e a paráfrase acima, notamos que Durkheim oferece uma versão substancialmente modificada do trecho original, que poderia ser qualificada como um caso de reimaginação teórica da etnografia de Spencer e Gillen (WATTS Miller, 2012b). Notadamente, Durkheim transforma a descrição da vida do jovem iniciado, considerada dividida entre duas partes, em uma divisão do tempo cíclica entre dispersão e concentração que diz respeito às sociedades australianas como um todo. Com efeito, ele aponta que a população se concentra para as cerimônias religiosas em períodos determinados, sugerindo uma noção de tempo cíclico entre os australianos baseada na variação sazonal entre os tempos de concentração da vida religiosa e dispersão da vida cotidiana. Todavia, não existem quaisquer informações factuais ou interpretações sobre esse tema nas etnografias sobre os povos australianos. É, portanto, a partir das variações sazonais entre os tempos sagrado e profano elaborada por Mauss 
que Durkheim reimagina a descrição de Spencer e Gillen e dá, então, o primeiro passo de sua explicação.

Em seguida, Durkheim seleciona a descrição de Spencer e Gillen de uma cena ritual característica dos períodos de concentração e celebração religiosa. Trata-se de um conjunto de cerimônias warramunga dedicadas à serpente Wollunqua, organizada pela fratria Kingilli e performada pela fratria Uluuru. No local da cerimônia, a fratria Kingilli utiliza areia e penas vermelhas para desenhar no solo os grafismos que representam Wollunqua. No quarto dia de uma série de cerimônias, Spencer e Gillen narram o seguinte:

Later on, towards nine or ten o'clock, the Uluuru and other Kingilli men came on to the ground, more fires were lighted, and all of the men sat round the mound singing refrains such as those above. Every one was evidently very excited. Late on in the evening the leading Uluuru men brought their lubras up and, as described elsewhere, invited the older Kingilli men to have intercourse with them. The women were not of course allowed to see the mound. Still later on, three recently initiated youths were brought up under the charge of their guardians, and everything was carefully explained to them. After this, and until three o'clock in the early morning, singing went on without a pause. Then, amidst a scene of the wildest excitement, fires were lighted all around the ceremonial ground, making the white trunks of the gum-trees and the surrounding scrub stand out in strong contrast to the darkness beyond. The Uluuru men ranged themselves in single file, kneeling beside the mound, and with their hands upon their thighs surged round and round it, every man in unison bending over first to one side and then to the other, each successive movement being accompanied by a loud and simultaneous shout. The Kingilli men were standing all around in a state of the greatest excitement, the oldest man amongst them swaying his body about as, with exaggerated high-knee action, he walked backwards at the head of the kneeling procession of Uluuru men. As the Kingilli clanged their boomerangs together, the Uluuru swayed about wildly from side to side, shouting, or rather yelling, at each movement, "Yrrsh! yrrsh! yrrsh!" until they had passed twice completely round the mound. Then, as the fires died away, they arose from their knees, and for another hour every one sat round the mound singing incessantly. Every now and again the singing would flag and almost die away, and then suddenly break out afresh, until at four o'clock, when the earliest streak of dawn appeared in the cast, every man jumped to his feet. Fires were once more lighted, shining brilliantly on the bodies of the men and throwing into strong relief the white mass of down upon the mound, round which the Uluuru ranged themselves. Urged on by the Kingilli, the Uluuru men fiercely attacked the mound with spears, boomerangs, clubs, and spearthrowers, until, in a few minutes, it was hacked to pieces, and all that remained was a rough heap of sandy earth. The fires died down, and for a short time there was silence (SPENCER; GILLEN, 1904, p. 237-238; grifo nosso). 
Com pequenas alterações de estilo, Durkheim parafraseia de maneira relativamente fiel a cena descrita acima pelos etnógrafos britânicos (cf. DURKHEIM, 1912, p. 310-311). Em seu comentário, ele mobiliza três ideias chave para sua interpretação do ritual warramunga, a saber: efervescência, ritmo e transfiguração. Nesse sentido, Durkheim argumenta que a reunião dos membros libera "une sorte d'électricité qui les transporte vite à un degré extraordinaire d'exaltation" (DURKHEIM, 1912, p. 308), desencadeando um estado de superexcitação ou efervescência tão violento que, movidos por esse sentimento coletivo, os envolvidos agem para além da moral ordinária, transgredindo-a ostensivamente. A esse respeito, uma das maneiras de extravasar as paixões liberadas e intensificar o estado de êxtase consiste justamente nos gestos e gritos violentos, que ocorrem sob "un certain ordre qui permette le concert et les mouvements d'ensemble" e, por conseguinte, “ces gestes et ces cris tendent d'eux-mêmes à se rythmer et à se régulariser" (DURKHEIM, 1912, p. 309; grifo nosso), transformando-se, por meio do ritmo, em cantos e danças. Finalmente, os adereços, pinturas, máscaras e a dramatização performada pelos Warramunga "figurent matériellement cette transformation intérieure", em que todos são transportados para "un milieu tout peuplé de forces exceptionnellement intenses, qui l'envahissent et le métamorphosent" (DuRKHEIM, 1912, p. 312; grifo nosso). Dessa maneira, ao participar do ritual dedicado à serpente Wollunqua, o participante é arrebatado por um poder exterior que o faz agir e pensar de maneira diferente, transfigurando-o em um novo ser pertencente ao mundo das coisas sagradas. Conforme arregimenta em sua explicação:

C'est donc dans ces milieux sociaux effervescents et de cette effervescence même que paraît être née l'idée religieuse. Et ce qui tend à confirmer que telle en est bien l'origine, c'est que, en Australie, l'activité proprement religieuse est presque tout entière concentrée dans les moments où se tiennent ces assemblées. [...] La vie pieuse de l'Australien passe donc par des phases successives de complète atonie et, au contraire, d'hyper-excitation, et la vie sociale oseille suivant le même rythme (DURKHEIM, 1912, p. 313; grifo nosso).

De acordo com Durkheim, a noção de mana é originada da efervescência ou dos estados de êxtase coletivo produzidos nos meios rituais. Segundo o autor, nas sociedades elementares australianas a atividade religiosa é circunscrita aos períodos de concentração das grandes reuniões sagradas, que ocorrem periodicamente em alternância com períodos de dispersão nos quais impera a vida profana. Tal alternância entre os tempos de efervescência e inércia da vida religiosa ditam, por sua vez, o 
compasso da vida social australiana, conformando uma noção de tempo cíclico. Tem-se, portanto, tal como desenvolvida por Hubert e Mauss, a explicação de como uma ideia é produzida no meio ritual, se generaliza e caracteriza o meio social mais amplo, ditando o ritmo da vida coletiva australiana.

Da análise da origem da noção de mana totêmico procede que os seres espirituais não figuram nas cerimônias totêmicas elementares e seriam, portanto, produtos secundários da evolução religiosa. No entanto, dada a homogeneidade da civilização australiana, seria possível traçar o desenvolvimento imanente dessas noções nas tribos da Austrália central, tomando como ponto de partida a gênese da noção de alma. A esse respeito, sabemos por Spencer e Gillen que os Arunta possuem uma quantidade definida de almas, e que nada mais são que as almas sagradas dos ancestrais míticos do alcheringa, que reencarnam periodicamente por meio das churingas nos novos membros do grupo. Por um lado, Durkheim sustenta que a noção de alma nada mais é que uma fração da "force anonyme qui est à la base du culte, mais incarnée dans un individu dont elle épouse la personnalité ; c'est du mana individualisé" (DURKHEIM, 1912, p. 378). Tal concepção subsidia, inclusive, sua tese mais geral sobre a dupla natureza do homem, na qual a alma individual seria um modo de representação singular dos ideais sagrados que conformam a alma coletiva. Por outro lado, Durkheim está particularmente interessado no problema das transformações da alma australiana, fenômeno também conhecido como metempsicose. As almas dos antepassados são representadas com predominância da forma animal sobre a humana e, não raro, transformam-se em animais ou plantas da espécie totêmica. Quando desligadas do corpo, as almas encarnam nas churingas, consideradas o corpo comum do membro do clã e de seus antepassados. Ao reencarnar em um novo membro do clã, cada indivíduo “est donc considéré comme un nouvel avatar d'un ancêtre déterminé" (DURKHEIM, 1912, p. 354; grifo nosso). Dessa maneira, Durkheim considera que há uma equivalência entre ancestral, churinga e humano, uma vez que todos esses elementos são pensados sob a aparência do ser totêmico, isto é, como variantes de uma mesma representação figurada e podem, portanto, se transfigurar uns nos outros (DURKHEIM, 1912, p. 381).

Segundo Durkheim, a noção de alma está na gênese tanto das noções de espírito, herói e deus, quanto da noção de pessoa. A alma constitui uma noção elementar de 
personalidade e, consequentemente, de pessoa, baseada na junção de dois fatores: de um princípio coletivo e impessoal e de um fator de individuação, isto é, o corpo. No entanto, quando desvinculada de um objeto ou corpo determinado, as almas se transformam em personalidades míticas de ordem superior tais como os gênios mobilizados nos ritos mágicos, e também nos espíritos dos heróis civilizadores do alcheringa, caso da serpente Wollunqua, um ancestral warramunga que se tornou objeto de festas em sua celebração e poderia ser considerado um deus do clã (DURKHEIM, 1912, p. 396). Há, ainda, relatos acerca da existência de um grande deus tribal acima dos heróis míticos: Altjira, que é o objeto do culto de iniciação praticado por toda a tribo. O deus é adorado com cantos e danças e até preces: "On danse tout autour ; on chante en son honneur ; on lui adresse même de véritables prières" (DURKHEIM, 1912, p. 412). Tal como Mauss, Durkheim sustenta que haveria o desenvolvimento de uma noção indígena de deus como processo de síntese de todos os totens e a consequente personificação da unidade tribal (DURKHEIM, 1912, p. 421). Em resumo, as noções de alma e de personalidades míticas consistem em representações figuradas da mesma noção de força sui generis que está na base do culto totêmico.

Não obstante todas as transformações das crenças religiosas, elas continuam a representar de uma maneira específica as forças sociais em ação, isto é, por meio de figurações. Ao buscar a origem desse modo de simbolização no totemismo australiano, Durkheim observa que embora os indígenas tivessem condições de representar fielmente os seres totêmicos, "les décorations sacrées semblent, le plus souvent, étrangères à toute préoccupation de ce genre"; ao contrário, essas representações têm um caráter eminentemente estético, uma vez que a relação entre "la figure, et la chose figurée est tellement indirect et lointain qu'on ne peut l'apercevoir quand on n'est pas averti” (DURKHEIM, 1912, p. 178-179). Além disso, os grafismos e desenhos geométricos usados para representar os totens possuem um sentido determinado pela convenção e estão na origem tanto das artes plásticas quanto da própria escrita. Ao mesmo tempo, essas representações figuradas são consideradas o clã hipostasiado em imagens sensíveis ou, simplesmente, o signo material que expressa a força social do clã. Isso se deve, segundo Durkheim, ao fato de que o homem comum jamais foi capaz de exprimir essa força sui generis, que ele sente e lhe é imanente, senão por meio desses símbolos religiosos figurados. Para explicar essa relação entre símbolos, sentimentos e 
ideias coletivas, Durkheim afirma que os sentimentos despertados em nós por uma coisa se transmitem ao símbolo que a representa e, consequentemente, as emoções provocadas pela coisa também são transferidas contagiosamente ao símbolo. Isso se deve, segundo o autor, à dificuldade de abarcar com o pensamento as coisas sociais dada sua complexidade e elevado grau de abstração, pois não "nous ne saurions voir dans une entité abstraite, que nous ne nous représentons que laborieusement et d'une vue confuse, le lieu d'origine des sentiments forts que nous éprouvons" (DURKHEIM, 1912, p. 314). Ao contrário, para tornar tais sentimentos e ideias inteligíveis a nós mesmos é preciso representá-los por meio de símbolos concretos e simples, que nos conectam diretamente a esses sentimentos coletivos: "C'est le signe alors qui prend sa place ; c'est sur lui qu'on reporte les émotions qu'elle suscite. C'est lui qui est aimé, craint, respecté ; c'est à lui qu'on est reconnaissant ; c'est à lui qu'on se sacrifie" (DURKHEIM, 1912, p. 315). Tal como a bandeira que suscita sentimentos patrióticos - e sendo a pátria, ela mesma, uma coisa social difícil de se representar no pensamento -, o emblema totêmico suscita os sentimentos e ideias do clã - sendo o clã, ele mesmo, uma realidade coletiva também difícil de conceber em sua unidade. Sob essa perspectiva, deuses e totens não são senão a expressão figurada da sociedade: ou seja, são noções por meio das quais os indivíduos representam alegoricamente "la société dont ils sont membres, et les rapports, obscurs mais intimes, qu'ils soutiennent avec elle" (DURKHEIM, 1912, p. 323; grifo nosso). A exemplo dos meios rituais, Durkheim argumenta que para que as consciências de cada um possam se comunicar e a comunhão ocorrer é preciso que estejam presentes intermediários concretos, tais como os movimentos estereotipados e dramáticos, pois "une fois que ces mouvements ont pris une forme une et stéréotypée, ils servent à symboliser les représentations correspondantes" e é, portanto, “l'homogénéité de ces mouvements qui donne au groupe le sentiment de soi et qui, par conséquent, le fait être" (DURKHEIM, 1912, p. 330). É por essa razão que Durkheim sustenta que essas representações figuradas, características do simbolismo religioso, são em realidade o meio necessário para a sociedade tomar consciência de si e assegurar a continuidade dessa consciência. Esse é o fundamento da famosa generalização de Durkheim de que "la vie sociale, sous tous ses aspects et à tous les moments de son histoire, n'est possible que grâce à un vaste symbolisme”, isto é: "Les emblèmes matériels, les représentations figurées, dont nous avons plus 
spécialement à nous occuper dans la présente étude" (DURKHEIM, 1912, p. 331-332). Graças à superexcitação das forças intelectuais nos meios rituais, portanto, foi possível “créer tout un monde d'idéaux à travers lequel le monde des réalités senties apparût transfiguré" (DURKHEIM, 1912, p. 340; grifo nosso). No totemismo australiano, ao se admitir a crença de que todos os seres que partilham do mesmo emblema são parte da mesma natureza, se tornou possível admitir que eles também podiam transformar-se uns nos outros e, principalmente, explicar a gênese das coisas por meio dessas transformações. Por mais distante que isso pareça do raciocínio científico, afirmar que um homem é um canguru, ou que o Sol é um pássaro não é qualitativamente diferente de afirmar que o calor é um movimento, ou que a luz é uma vibração: em ambos os casos, trata-se do princípio de identidade que o pensamento religioso ajudou a formar, tão caro às metamorfoses quanto às explicações científicas. Nesse sentido, Durkheim considera a religião uma espécie de matriz dos fenômenos da vida moral e material, posto que ela abarcou "la réalité tout entière, l'univers physique aussi bien que l'univers moral, les forces qui meuvent les corps comme celles qui mènent les esprits ont été conçues sous forme religieuse" (DURKHEIM, 1912, p. 319).

Considerando a contínua capacidade das sociedades de criar coisas e ideias sagradas, Durkheim estende sua análise da gênese das ideias e dos sentimentos elementares nos meios rituais para outras épocas criadoras ou revolucionárias. Assim como a Austrália, a Europa também protagonizou eventos que resultaram em estados de efervescência geral, isto é, estados de superexcitação que desencadeiam atos de barbárie e heroísmo. Ao engajarem-se nesses eventos, os envolvidos representavam religiosamente esse estado de êxtase: os cruzados sentiam a presença de deus ordenando-os a conquista da terra santa, ao passo que Jeanne d'Arc ${ }^{3}$ dizia obedecer a vozes celestes (DURKHEIM, 1912, p. 302). Para Durkheim, os estados de efervescência explicam tanto as Cruzadas quanto as cenas, "ou sublimes ou sauvages, de la Révolution française", em que foi possível observar até "le bourgeois le plus médiocre ou le plus inoffensif se transformer soit en héros soit en bourreau" (DURKHEIM, 1912, p. 301). Retomando os trabalhos de Albert Mathiez ${ }^{4}$ sobre a origem dos cultos revolucionários, Durkheim sustenta que a Revolução Francesa estabeleceu as bases de

3 Jeanne d'Arc foi beatificada em 1909 e canonizada em 1920 pela igreja católica.

4 Sobre a recepção da obra de Mathiez por Durkheim, cf. Edward Tiryakian (1988). 
uma religião civil ao sacralizar ideais laicos como os de razão, pátria e liberdade. Conforme comenta o autor:

Cette aptitude de la société à s'ériger en dieu ou à créer des dieux ne fut nulle part plus visible que pendant les premières années de la Révolution. A ce moment, en effet, sous l'influence de l'enthousiasme général, des choses, purement laïques par nature, furent transformées par l'opinion publique en choses sacrées : c'est la Patrie, la Liberté, la Raison. Une religion tendit d'elle-même à s'établir qui avait son dogme, ses symboles, ses autels et ses fêtes. [...] Cette rénovation religieuse n'eut, il est vrai, qu'une durée éphémère. Mais c'est que l'enthousiasme patriotique qui, à l'origine, transportait les masses, alla lui-même en s'affaiblissant. La cause disparaissant, l'effet ne pouvait se maintenir. [...] Il reste que, dans un cas déterminé, on a vu la société et ses idées essentielles devenir, directement et sans transfiguration d'aucune sorte, l'objet d'un véritable culte (DURKHEIM, 1912, p. 305-306; grifo nosso).

Tomando por referência a explicação da gênese das ideias e sentimentos sagrados nos meios rituais efervescestes, a análise de Durkheim sobre a Revolução Francesa desdobra-se em duas direções. A primeira é a que enfatiza a continuidade entre os rituais australianos e europeus, identificando o mecanismo elementar de ação ritual que permite tanto a produção do mana no totemismo australiano quanto a do sagrado na Revolução Francesa. Nesse sentido, importa salientar como as festas, o êxtase e as figurações simbólicas desse período revolucionário criaram um culto de ideais sagrados, mas laicos, que constituem o germe da religião civil. Já a segunda enfatiza a descontinuidade entre os rituais da religião totêmica e da religião civil. Ao contrário do totemismo, em que o objeto de culto é uma representação transfigurada do clã por meio do emblema totêmico, o culto revolucionário teria como objeto a sociedade e suas ideias representados diretamente, ou seja, sem transfiguração de nenhuma espécie. De acordo com essa segunda linha de análise, a Revolução Francesa teria sido um evento cujas forças efervescentes dos meios rituais teriam criado representações transparentes da sociedade e de seus ideais, sem o misticismo e opacidade característicos das representações religiosas figuradas. Para além do problema de se os ideais de pátria, liberdade e razão eram, em si mesmos, representações transparentes da sociedade - o que já era objeto de crítica e discussão mesmo antes de Durkheim ${ }^{5}$-, ou se eram apenas

5 Longe de tentar refutar Durkheim empiricamente sobre essa questão, basta lembrar que haviam outras interpretações do legado da Revolução Francesa, tais como a realizada por Marx, muito antes, que enfatizava o jogo da burguesia em lançar mão de ideias abstratas e pretensamente universais como estratégia de subordinação de outros grupos sociais à realização de seus interesses particulares. Não obstante, veremos mais adiante como Durkheim retoma esse problema sob outro prisma em seu curso 
emblemas figurados do culto revolucionário, o fato é que a possibilidade de criar ideias transparentes por meio de rituais efervescentes parece contradizer toda a abordagem desenvolvida por Durkheim em seu livro até aqui. Ao resenhar os mesmos trabalhos de Mathiez sobre os cultos revolucionários para o Année, Mauss já havia observado que "les faits abondent qui démontrent que de ces assemblées se dégageait une espèce de mystique, qu'elles créaient des symboles (arbre de mai, drapeau, etc.), dont elles exigeaient le respect et même le culte" (MAUSS, 1905d, p. 297). Além disso, é difícil pensar como a selvageria e a barbárie que acometeu até o burguês mais medíocre possa ter originado representações claras e transparentes da sociedade durante o êxtase revolucionário ${ }^{6}$. Conforme observa Watts Miller, ao apontar a mesma contradição na interpretação de Durkheim sobre a Revolução Francesa: “A superabundant, hyperactive, volcanic upsurge of energy might seem a guarantee of transfiguration" (WATTS MILLER, 2012a, p. 123).

A despeito dessa contradição, Durkheim reitera em diversas oportunidades no livro a homologia entre os modos de representação das sociedades indígenas e modernas. A exemplo da noção de alma, ele considera que seus contemporâneos europeus não teriam uma concepção mais clara e coerente do que aquela dos indígenas australianos (DURKHEIM, 1912, p. 344-345). Conforme avalia o autor, ao justificar sua empreitada: "Pour ce qui concerne les faits sociaux, nous avons encore une mentalité de primitifs" (DURKHEIM, 1912, p. 37). Tal proximidade entre os pensamentos indígena e moderno se deve, justamente, ao tratamento simplista que o senso comum aplica a essas questões, considerando os fenômenos sociais "la chose plus claire du monde" (DURKHEIM, 1912, p. 37). Em contrapartida, caberia à ciência social dissipar a ilusão de transparência e reconhecer a obscuridade inerente à vida social. Conforme conclui o autor:

Sans doute, s'il pouvait voir immédiatement que ces influences qu'il subit émanent de la société, le système des interprétations mythologiques ne serait pas né. Mais l'action sociale suit des voies trop détournées et trop obscures, elle emploie des mécanismes psychiques trop complexes pour qu'il soit possible à l'observateur vulgaire d'apercevoir d'où elle vient. Tant que l'analyse scientifique n'est pas venue le lui apprendre, il sent bien qu'il est agi, mais non par qui il est agi. Il dut donc construire de toutes pièces la notion de ces puissances avec lesquelles il se sentait en rapports, et, par là, on peut entrevoir déjà comment il fut amené à se les

sobre o pragmatismo.

6 Na mesma linha da interpretação de Mauss, cf. a análise de Mona Ozuf (1988) sobre a Revolução Francesa como uma festa revolucionária. 
représenter sous des formes qui leur sont étrangères et à les transfigurer par la pensée (DURKHEIM, 1912, p. 299; grifo nosso).

Assim, a obscuridade seria um elemento inerente à complexidade dos mecanismos da ação social, e a transfiguração a única maneira de traduzir esses mecanismos e torná-los inteligíveis para seus produtores. As representações figuradas seriam, portanto, o meio de reduzir a complexidade desses fenômenos e torná-los assimiláveis por meio de símbolos materiais e concretos. Conforme Durkheim reconhece, somente a análise científica poderia trazer à luz os mecanismos complexos e obscuros da ação social e, assim, construir explicações transparentes desses mecanismos. Ainda que Durkheim tivesse esperança de que a ciência social poderia disseminar representações transparentes sobre as forças coletivas em ação, ele também reconhece que elas seriam, na melhor das hipóteses, um conhecimento de segunda ordem produzido por cientistas e não o conhecimento produzido pelo homem comum em meio às paixões violentas e ao êxtase dos meios rituais efervescentes.

\subsection{As práticas religiosas elementares}

O objetivo do Livro III de Les formes élémentaires de la vie religieuse é investigar e classificar as atitudes rituais mais elementares presentes entre os povos australianos. Ao dividir o culto entre negativo e positivo, Durkheim afirma que o primeiro tipo consiste, pois, nos tabus ou interdições, isto é, nas proibições ou atos negativos que visam separar as coisas sagradas das profanas. Fundamentalmente, as interdições religiosas evitam que as vidas sagrada e profana coexistam em um mesmo espaço ou em um mesmo intervalo de tempo; assim, tanto o local onde são depositadas as churingas pode ser concebido como um santuário, proibido para não-iniciados, quanto as festas são a expressão desse tempo sagrado, separado do tempo profano (DURKHEIM, 1912, p. 440-441). A necessidade advém, segundo Durkheim, da extraordinária contagiosidade e fugacidade das coisas sagradas que, por essa razão, devem ser protegidas do contato com as coisas profanas. Com efeito, as interdições são nada mais que o símbolo material que figura a heterogeneidade radical entre as noções de sagrado e profano: "Pour que les idées ne coexistent pas, il faut que les choses ne se touchent pas, ne soient d'aucune manière en rapports. C'est le principe même de l'interdit' (DURKHEIM, 1912, p. 454). Se, por um lado, as interdições visam proteger o sagrado do contato com o profano, a 
observância dessas interdições tem como efeito transformar radicalmente o estado de seus praticantes - situação comumente representada nas cerimônias de iniciação como uma espécie de segundo nascimento. Assim, as interdições do culto negativo possuem seu lado positivo, qual seja: o de alçar os homens para além de sua condição profana um organismo que sente dor, cansaço e fome, por exemplo -, e torná-los aptos ao contato com as coisas sagradas. Das cerimônias de iniciação australiana até os deuses das religiões mundiais, Durkheim observa como as interdições elementares desenvolveram-se a ponto de formar um sistema cada vez mais coerente de ritos ascéticos que tem o efeito de elevar certos humanos a uma condição análoga à dos deuses - tal como a de Buda, por exemplo. Portanto, o ascetismo é uma espécie de representação figurada de que o homem se elevou acima da coisas ordinárias, precisamente porque "il y a renoncé ; il est plus fort que la nature puisqu'il la fait taire" (DURKHEIM, 1912, p. 451).

Temos, em seguida, a investigação dos ritos que conformam o culto positivo, cujo objeto principal é a festa intichiuma. Coincidentemente, Durkheim seleciona os mesmos autores utilizados por Mauss em sua tese sobre a prece - Spencer e Gillen, Strehlow e até mesmo Schulze -, bem como retoma como centro de sua análise o mesmo intichiuma do clã da lagarta Witchetty, complementado pelo intichiuma warramunga à cobra-preta Thalaualla. Uma vez reunidos todos os membros do totem no acampamento principal, eles marcham devotamente pelo caminho que também passaram seus antepassados, parando nos mais de dez locais em que estão depositadas as grandes pedras de quartzo que representam a lagarta Witchetty. Em cada um desses locais, o rito é o mesmo: o chefe local bate a bacia de madeira e canta ${ }^{7}$ convidando o animal a pôr ovos, seguido dos demais presentes, que retomam o mesmo canto e batem no bloco com suas ramagens; em seguida, repetem-se os mesmos canto e gesto, mas agora com as pedras que representam os ovos da lagarta e, com uma delas, o chefe esfrega o estômago de cada participante. Segundo Durkheim, ao bater nas pedras sagradas, o chefe libera a poeira que carrega o princípio mana e que, ao ser dispersada pelas ramagens, garante a reprodução abundante da espécie totêmica (DURKHEIM, 1912, p.

7 Apesar dos cantos serem parte constitutiva de todas as cerimônias australianas, Durkheim diz que os deixaria de lado pois haveria, em breve, uma obra especialmente dedicada aos ritos orais - sem, no entanto, mencionar o nome de Mauss (DURKHEIM, 1912, p. 427, n. 1) 
469-470). Em seguida, todos se adornam e marcham $^{8}$ no caminho de volta em direção à longa cabana de folhas que representa o casulo da lagarta; ao entrarem, começam a cantar a respeito das sucessivas transformações da lagarta totêmica, enquanto os membros da outra fratria permanecem imóveis com o rosto virado para o chão; no fim, todos rastejam para fora da cabana performando e cantando ao mesmo tempo os movimentos executados pela lagarta durante o nascimento (DURKHEIM, 1912, p. 501502). Findo o primeiro ato da festa, os membros do clã enfrentam um período de rígida proibição de manipular o totem, que só termina com uma última cerimônia, em que os membros saem para apanhar as lagartas que cresceram logo depois das chuvas; elas são cozidas e armazenadas em vasos de madeira e, posteriormente, moídas e ingeridas com moderação pelo chefe e pelos membros do clã. Segundo Durkheim, a comensalidade moderada é necessária porque, do contrário, o clã perderia o poder necessário para continuar a celebração do intichiuma e, consequentemente, a espécie totêmica não se reproduziria (DURKHEIM, 1912, p. 477-478). Por fim, Durkheim retoma a cerimônia warramunga dedicada à cobra Thalaualla, cujos ritos consistem em representações dramáticas para celebrar o antepassado em questão (DURKHEIM, 1912, p. 531). No rito de abertura, dois participantes ornamentados com desenho emblemático da cobra-preta correm e saltam até caírem exaustos no chão; ao mesmo tempo, os assistentes tocam suavemente os desenhos emblemáticos para agradar o totem ancestral. Em seguida, o rito principal performa a história mítica de Thalaualla: para representar o movimento ancestral de liberação dos germes de vida, os atores, com a pele coberta por uma penugem, performam "une sorte de trémoussement rythmé et violent du corps tout entier" e, com esse movimento, espalham a penugem pelo ar como "une manière de figurer l'envolée de ces germes mystiques et leur dispersion dans l'espace" (DURKHEIM, 1912, p. 532; grifo nosso). Da mesma maneira, a festa warramunga dedicada à serpente Wollonqua - a mesma analisada por Durkheim no Livro II - também consiste em um conjunto de figurações dos acontecimentos de sua vida fabulosa no tempo do alcheringa.

8 Na descrição de Mauss da mesma performance, ele diz que as decorações se tratam exatamente de pinturas corporais do emblema totêmico, e que os movimentos executados ao longo da marcha simulam aqueles da lagarta. É curioso que Durkheim tenha investido tanto na relevância do emblema totêmico e, aqui, se contente em descrevê-la genericamente como uma simples ornamentação. 
A partir da reconstrução do intichiuma arunta e warramunga, Durkheim deriva uma série de classificações dos ritos narrados. Dentre estes, os mais evidentemente alinhados são os chamados ritos miméticos e os ritos comemorativos. Seguindo as indicações de Hubert e Mauss, Durkheim sustenta que os ritos miméticos são considerados os mais elementares e consistem em gestos e gritos que objetivam imitar certos aspectos do animal totêmico, tal como exemplificado no intichiuma da lagarta Witchetty. Para Durkheim, para além do elemento estético, os ritos miméticos são figurações em que o simples fato de imitar o animal ritualmente tem o poder de criar o animal totêmico. Isso porque o totem é signo de comunhão do clã que "le rite ne se borne pas à l'exprimer ; il la fait ou la refait" (DURKHEIM, 1912, p. 511; grifo nosso). Dessa maneira, Durkheim pensa os ritos miméticos como a expressão figurada dos desejos e ideias ensejadas coletivamente pelos membros do clã:

Puisque tous pensent à l'animal ou au végétal des destinées duquel le clan est solidaire, il est inévitable que cette pensée commune vienne se manifester extérieurement par des gestes, et les plus désignés pour ce rôle sont ceux qui représentent cet animal ou cette plante par un de ses aspects les plus caractéristiques ; car, il n'est pas de mouvements qui tiennent d'aussi près à l'idée qui remplit alors les consciences, puisqu'ils en sont la traduction immédiate et presque automatique. On s'efforce donc d'imiter l'animal ; on crie comme lui ; on saute comme lui ; on reproduit les scènes où la plante est quotidiennement utilisée. Tous ces procédés de figuration sont autant de moyens de marquer ostensiblement le but vers lequel tous les esprits sont tendus, de dire la chose qu'on veut réaliser, de l'appeler, de l'évoquer (DURKHEIM, 1912, p. 512; grifo nosso)

Nesses termos, os ritos miméticos são performances que traduzem materialmente e de maneira imediata o pensamento do clã em torno da espécie totêmica. São, portanto, nada mais que figurações que objetivam evocar a reprodução da espécie totêmica e, ao tempo, recriar seu parentesco com ela. Da mesma maneira, os ritos comemorativos são aqueles nos quais a representação dramática é ainda mais evidente, a ponto de Durkheim assinalar frequentemente os participantes do ritual como atores que estão representando seus papéis durante as figurações míticas. Os rituais warramunga, tais como os arunta, "sont des drames, mais d'un genre tout particulier : ils agissent, ou, du moins, on croit qu'ils agissent sur le cours de la nature"; em ambos os casos, a representação dramática performa a ação dos heróis míticos do alcheringa por meio de danças e "des chants qui racontent les exploits ancestraux" (DURKHEIM, 1912, p. 534; grifo nosso). Conforme concluí, o caráter dramático das atitudes rituais australianas 
“mettent en évidence un important élément de la religion : c'est l'élément récréatif et esthétique" (DURKHEIM, 1912, p. 542). Nesse esquema, os elementos estéticos e lúdicos da ação dramática são mobilizados pelo grupo para recriar periodicamente o sentimento que têm de si mesmos e de sua unidade.

Retomando os trabalhos de Hubert e Mauss sobre o poder mágico, Durkheim afirma que o princípio contido nesses ritos, qual seja, o de que o semelhante produz o semelhante, implica uma espécie de concepção elementar de relação causal: isto é, uma ideia de eficácia baseada em um poder ou força capaz de produzir uma mudança determinada. Ora, o protótipo da ideia de força não é senão a noção de mana, concebida como uma das ideias mais elementares de força social. Conforme comenta o autor:

l'idée de force porte, d'une manière apparente, la marque de son origine. Elle implique, en effet, l'idée de pouvoir qui, à son tour, ne va pas sans celles d'ascendant de maîtrise, de domination, et corrélativement, de dépendance et de subordination ; or, les relations que toutes ces idées expriment sont éminemment sociales. C'est la société qui a classé les êtres en supérieurs et en inférieurs, en maîtres qui commandent et en sujets qui obéissent ; c'est elle qui a conféré aux premiers cette propriété singulière qui rend le commandement efficace et qui constitue le pouvoir. Tout tend donc à prouver que les premiers pouvoirs dont l'esprit humain ait eu la notion sont ceux que les sociétés ont institués en s'organisant : c'est à leur image que les puissances du monde physique ont été conçues (DURKHEIM, 1912, p. 522-523).

Durkheim retoma, então, o problema das classificações - mas enfocando, dessa vez, as relações de hierarquia e dominação que estas implicam. Nesse sentido, a sociedade fornece, sim, por meio de seus rituais, elementos que contribuem para a elaboração de juízos de valor e até mesmo para a epistemologia, como é o caso da noção de causalidade. No entanto, o que a ação ritual produz e agencia é, sobretudo, o poder social em estado bruto, que é instituído com o objetivo de organizar a própria sociedade - o que torna as contribuições à epistemologia e à explicação da natureza uma consequência apenas secundária desta. Antes de servir à ciência ou à teoria do conhecimento, Durkheim sustenta que o poder social serve fundamentalmente aos seus próprios fins morais.

Além dos ritos miméticos e comemorativos, Durkheim identifica um terceiro tipo de prática ritual presente no intichiuma, aquela que diz respeito aos atos de comensalidade e oblação. A esse respeito, apesar de Smith ser mencionado com frequência, Durkheim está, na verdade, discutindo com os trabalhos de Hubert e Mauss 
sobre o sacrifício. Em 1908, os autores reconhecerem a comensalidade como um rito característico do intichiuma, mas observaram a falta do elemento definidor do sacrifício, a oblação, ou, a oferta da coisa sacrificada à divindade (HUBERT; MAUSS, 1908, p. 167). Durkheim, por sua vez, em seu curso de 1906-1907, havia defendido o intichiuma como a prova da existência de sacrifícios totêmicos, o que lhe parecia permitir explicar a evolução do culto positivo desde o totemismo até as religiões mais idealistas. Sua reação à crítica de Hubert e Mauss, então, consiste em: 1) provar a existência de oblações no intichiuma, e 2) repensar a posição do intichiuma na genealogia do sacrifício. Retomando o primeiro ato da cerimônia arunta, Durkheim afirma que a dispersão da poeira da rocha sagrada consiste na liberação de partículas de mana que servem para animar e assegurar a renovação da espécie totêmica. Com efeito, ao realizar esse rito, "[1]e geste par lequel se fait cette dispersion est aussi celui qui accompagne normalement les offrandes"; à diferença do oferenda dirigida aos deuses nas cerimônias sacrificiais, “en Australie, il est donné à l'espèce sacrée (DURKHEIM, 1912, p. 488-489). Rebatendo a crítica de Hubert e Mauss, Durkheim afirma: “On n'est donc plus fondé à voir dans l'idée d'oblation un produit tardif de la civilisation" (1912, p. 489). Por outro lado, Durkheim afirma que, no ato final do intichiuma, o chefe e os anciãos comem solenemente a espécie totêmica e, ao fazerem isso, eles "communient donc avec le principe sacré qui y réside et ils se l'assimilent" (DURKHEIM, 1912, p. 482). Assim, ao arregimentar comensalidade e oblação, Durkheim crê que o intichiuma "contient les germes du système sacrificiel", mas difere da versão típica do sacrifício devido ao intervalo de tempo que separa os ritos na variante arunta: “Toute la différence, c'est que, dans le sacrifice proprement dit, ils se font simultanément ou se suivent immédiatement, tandis que, dans la cérémonie australienne, ils sont disjoints" (DURKHEIM, 1912, p. 482). Além disso, Durkheim sugere que as cerimônias australianas não estariam distantes dos sacrifícios agrários, pois no caso australiano trata-se também de se alimentar das primícias da espécie totêmica. Tal como havia sido analisado por Hubert e Mauss no ensaio sobre o sacrifício, Durkheim sustenta que as cerimônias intichiuma contém atos de comunhão alimentar e oferenda aos deuses - ainda que, nesse caso, os deuses sejam imanentes ao clã e não tenham se transformado em personalidades míticas. Todavia, para superar a crítica feita pelos autores em 1908, Durkheim reconhece que a cerimônia arunta contém os elementos necessários para constituir 
sacrifício, mas em estado germinal - sem o modo de organização característico que assumiu nos sacrifícios hebreu e hindu.

Há, por fim, uma última categoria de ritos que não estão ligados ao intichiuma e designam genericamente toda sorte de práticas cerimoniais relacionadas à tristeza, à infelicidade ou à expiação, os chamados ritos piaculares. Novamente, ainda que o nome de Smith apareça frequentemente, as principais referências são Hubert, Mauss e, principalmente, Robert Hertz, o especialista na questão ${ }^{9}$. A esse respeito, as cerimônias de luto são documentadas por Spencer e Gillen (1899 e 1904), que dedicaram capítulos inteiros a descrevê-las. Ao contrário da alegria presente no intichiuma, nas cerimônias de luto predominam as lamentações, choros, gemidos e autoflagelações dos participantes, tomados por um verdadeiro frenesi. Esses ritos prosseguem durante meses, e terminam com uma última cerimônia, na qual, conforme o relato de Spencer e Gillen, está presente um misto de cólera e tristeza das mulheres e, ao mesmo tempo, sua plasticidade: "The weeping and wailing of the women who were standing round seemed to drive them almost frenzied, and the blood, streaming down their bodies over the white pipe-clay, gave them a ghastly appearance" (SPENCER; GILLEN, 1899, p. 509510). Apesar da diferença dos sentimentos suscitados, Durkheim pondera que os ritos piaculares também são feitos de cerimônias que provocam estados de êxtase coletivos dentre os participantes, pois estes também protagonizam cenas de wildest excitement quando celebram o luto pela morte de seus afins. Dessa maneira, Durkheim afirma que a violência dessas manifestações diz respeito à sensação de enfraquecimento do grupo diante da perda de um de seus membros e, consequentemente, da necessidade de comunhão como forma de mobilizar as forças sociais efervescentes em prol do consolo e da reafirmação da vitalidade do grupo. Conforme conclui: "En un mot, alors même que les cérémonies religieuses ont pour point de départ un fait inquiétant on attristant, elles gardent, sur l'état affectif du groupe et des individus, leur pouvoir stimulant" (DURKHEIM, 1912, p. 583; grifo nosso). Além do luto, Durkheim dedica atenção para as cerimônias de expiação de sacrilégios. No entanto, ele mesmo reconhece que, na Austrália, "les rites piaculaires qui sont spécialement destinés à expier le péché

9 Apesar de ser citado por Durkheim apenas uma vez em uma das notas, Hertz havia escrito sobre as cerimônias de luto (1907), a polaridade religiosa entre os sagrados puro e impuro (1909), e estava escrevendo sua tese precisamente sobre a noção de expiação nas sociedades elementares sob a orientação de Marcel Mauss. Para uma reconstrução da obra de Hertz, cf. Robert Parkin (1996). 
semblent faire presque complètement défaut"; Durkheim, então, atribui essa ausência à insuficiências das próprias observações etnográficas, e insiste que os australianos, "comme tout homme, doit commettre des fautes rituelles qu'il a intérêt à racheter" (DURKHEIM, 1912, p. 580). Na falta de descrições sobre esses ritos, Durkheim retoma, então, parte da análise sobre a pena primitiva no judaísmo antigo, tal qual expressa em De la division du travail social. Segundo o autor, as violações de interdições rituais constituem uma ameaça à unidade moral do grupo, de modo que a reação passional, violenta e destrutiva contra a infração da regra é uma forma de expressar que essa violação constitui uma exceção e que a fé comum não foi abalada. Dessa maneira, "la peine infligée à titre d'expiation n'est que la manifestation de cette colère publique, la preuve matérielle de son unanimité" (DURKHEIM, 1912, p. 580). Durkheim sugere, então, que as penas se tratam de sacrificios expiatórios, e exemplifica essa sugestão citando duas passagens da bíblia judaica, sobre as quais comenta: "La victime immolée dans les sacrifices expiatoires est chargée d'impureté, puisqu'on a concentré sur elle les péchés qu'il s'agit d'expier" (DURKHEIM, 1912, p. 587). Numa das poucas passagens em que Durkheim tenta fundamentar tal interpretação, ele se limita a dizer, em uma nota de rodapé, que "[l]es sacrifices piaculaires [...] consistent exclusivement en oblations. Ils ne servent à des communions que d'une manière accessoire" (DURKHEIM, 1912, p. 490, n. 3). À primeira vista, a introdução dos sacrifícios expiatórios pode parecer uma crítica velada de Durkheim ao estudo do sacrifício realizado por Hubert e Mauss (PTACEK, 2005); todavia, Durkheim parece seguir de perto os argumentos de Hertz, que escrevia na época, sob a supervisão de Mauss, uma tese de doutorado sobre o pecado e a expiação nas sociedades polinésias ${ }^{10}$. Retomando o trabalho de Mauss sobre a origem religiosa do direito penal em um de seus cursos na EPHE, Hertz também reconhece a ausência de sanções organizadas contra a violação dos tabus entre os polinésios; não obstante, ele propõe investigar o estado germinal da instituição penal entre esses povos, ou seja, "pour quelles raisons et suivant quels modes une sanction humaine et proprement spéciale vient, en certains cas, s'ajouter à la sanction mystique qui frappe les violateurs du tabou" (HERTZ apud Mauss, 1911a, p. 87). Em curso anterior, Hertz já

10 Hertz foi um dos que morreram durante a Primeira Guerra Mundial e, por essa razão, jamais finalizou sua tese. Quando assumiu a cadeira de sociologia no Collège de France, Mauss ministrou uma série de cursos sobre a tese inacabada de Hertz, e tinha o interesse de dar prosseguimento à análise do material etnográfico polinésio para publicar a edição completa e acabada da tese de Hertz - projeto que não foi concluído. 
havia afirmado que o interesse no "étude du sacrifice expiatoire et de l'ascétisme pénitentiel" consiste em desvendar "les représentations et les émotions collectives dont procède la croyance en l'efficacité rédemptrice de la souffrance" (HERTZ apud Mauss, 1909b, p. 44). Nesse contexto, ele assume que o rito de oblação possui "une importance fondamentale dans l'expiation, où le pénitent apporte à l'être offensé du sang, de la vie, de la souffrance (victime immolée ou pratiques de mortification)" (HERTZ apud Mauss, 1909b, p. 44). Dessa maneira, Hertz relaciona o início das sanções humanas às sanções místicas oriundas das violações de interdições rituais, e o sacrifício expiatório à força coletiva e sagrada que fundamenta a ideia de redenção pela imolação e sofrimento das vítimas. Tal como Hertz, Durkheim assinala que tanto os ritos funerários quanto os de expiação estão ligados às forças sagradas impuras e malignas, bem como à personificação dessas forças pelo espírito dos mortos. A partir do momento em que a cólera provada é satisfeita pela execução do rito piacular, o sentimento coletivo ofendido é apaziguado e volta ao seu estado inicial. Consequentemente, "le sens de la force religieuse qui paraît l'occuper s'est inverti : d'impur, il est devenu pur et instrument de purification" (DURKHEIM, 1912, p. 591). Os ritos piaculares revelam, por essa razão, a ambiguidade inerente do sagrado, cujos polos alternam entre o puro e o impuro, o fasto e o nefasto, o divino e o diabólico. Conforme concluí, o puro e o impuro são variedades do mesmo gênero de forças transmutáveis entre si, pois é precisamente “dans la possibilité de ces transmutations que consiste l'ambiguïté du sacré" (DURKHEIM, 1912, p. 588).

A despeito das diferenças entre os diversos tipos de ritos apresentados, Durkheim aponta uma série de conclusões mais gerais sobre os elementos que conformam a unidade do culto positivo. A última que mencionamos refere-se ao problema das transformações entre as forças, seres e coisas, consideradas congêneres pelos australianos e heterogêneas pelos observadores europeus. Segundo o autor, isso se deve ao fato de todos esses elementos partilharem em algum grau a mesma força sagrada, considerada contagiosa e eficaz, que faz com que as outras características que os diferenciam sejam colocadas em segundo plano e, sobretudo, que sejam capazes de assumir as formas umas das outras por meio dos atos de comunhão: “C'est pourquoi il parut tout naturel de les ranger dans une même catégorie et de ne voir en eux que des variétés d'un même genre, transmutables les unes dans les autres" (DURKHEIM, 1912, p. 
464; grifo nosso). Por outro lado, Durkheim sustenta que a vida ritual deve ser interpretada em termos laicos e sociais, e que tal princípio sagrado, portanto, "n'est autre chose que la société hypostasiée et transfigurée" (DURKHEIM, 1912, p. 495). Nesse sentido, os seres e as ideias religiosas são dependentes de "les groupes assemblés", considerados "la source même de la vie religieuse", pois é por meio das assembleias que eles podem se refazer perpetuamente (DURKHEIM, 1912, p. 494). O culto positivo possui uma periodicidade que é expressa no ciclo de festas sazonais, no qual a alternância entre os tempos sagrado e profano exprime não só o ritmo da vida religiosa mas, fundamentalmente, o ritmo da vida coletiva em geral. Segundo o axioma de Durkheim: onde os períodos de dispersão são longos, como nas tribos australianas e norteamericanas, os períodos de concentração também são prolongados e produzem "véritables débauches de vie collective et religieuse. Les fêtes succèdent aux fêtes pendant des semaines ou des mois et la vie rituelle atteint parfois une sorte de frénésie"; ao contrário, onde os intervalos de dispersão e concentração são menores, como nas sociedades industriais, "le contraste entre elles est alors moins tranché", pois quanto mais "les sociétés se développent, moins elles semblent s'accommoder d'intermittences trop accentuées" (DURKHEIM, 1912, p. 500). Ainda assim, mesmo onde as festas e cerimônias públicas se tornaram laicas, elas ainda são capazes de produzir, eventualmente, efeitos análogos aos dos rituais religiosos stricto sensu:

l'idée même d'une cérémonie religieuse de quelque importance éveille naturellement l'idée de fête. Inversement, toute fête, alors même qu'elle est purement laïque par ses origines, a certains caractères de la cérémonie religieuse, car, dans tous les cas, elle a pour effet de rapprocher les individus, de mettre en mouvement les masses et de susciter ainsi un état d'effervescence, parfois même de délire, qui n'est pas sans parenté avec l'état religieux. L'homme est transporté hors de lui, distrait de ses occupations et de ses préoccupations ordinaires. Aussi observe-t-on de part et d'autre les mêmes manifestations : cris, chants, musique, mouvements violents, danses, recherche d'excitants qui remontent le niveau vital, etc. On a souvent remarqué que les fêtes populaires entraînent aux excès, font perdre de vue la limite qui sépare le licite et l'illicite ; il est également des cérémonies religieuses qui déterminent comme un besoin de violer les règles ordinairement les plus respectées. Ce n'est pas, certes, qu'il n'y ait pas lieu de différencier les deux formes de l'activité publique (DURKHEIM, 1912, p. 547-548; grifo nosso).

Segundo Durkheim, as festas laicas e religiosas, tais como o corroboree e o intichiuma australianos, diferem principalmente quanto à predominância do caráter grave e sério 
nas últimas, ao passo que caráter lúdico e divertido tende a predominar nas folias populares. Apesar dessa diferença, ambas as festas se caracterizam pelos estados de êxtase e de excesso coletivos expressos por meio de performances dramáticas e públicas que traduzem a comunhão dos participantes com os sentimentos e ideais sagrados e transcendentes.

Da mesma maneira, apesar de Durkheim ter investido na classificação dos distintos tipos de ritos, eles "chevauchent les uns sur les autres et peuvent même se remplacer mutuellement"; nesse sentido, tanto os "rites d'oblation et de communion, rites mimétiques, rites commémoratifs remplissent souvent les mêmes fonctions", quanto os ritos ascéticos e piaculares "sont faits de souffrances, acceptées ou subies, et auxquelles est attribuée une efficacité analogue" (DuRKHEIM, 1912, p. 592). Citando Hubert e Mauss (1899), essa plasticidade dos ritos revela que todos os seus efeitos particulares e definidos são apenas "simples variantes d'un seul et même mécanisme”, ou seja, todos consistem em uma mesma "action générale qui, tout en restant toujours et partout semblable à elle-même, est cependant susceptible de prendre des formes différentes suivant les circonstances" (DURKHEIM, 1912, p. 551-552). No caso australiano, Durkheim chega a oferecer uma reconstrução hipotética da origem do intichiuma, que é descrita e interpretada da seguinte maneira:

Des hommes qui se sentent unis [...] se considèrent comme participant tous de la nature d'un animal déterminé. Dans ces conditions, il n'y aura pour eux qu'une manière d'affirmer leur existence collective : c'est de s'affirmer eux-mêmes comme des animaux de cette même espèce, et cela non pas seulement dans le silence de la conscience, mais par des actes matériels. Ce sont ces actes qui constitueront le culte, et ils ne peuvent évidemment consister qu'en mouvements par lesquels l'homme imite l'animal avec lequel il s'identifie. [...] ces gestes naïfs et gauches, ces procédés grossiers de figuration, traduisent et entretiennent un sentiment de fierté, de confiance et de vénération tout à fait comparable à celui qu'expriment les fidèles de religions les plus idéalistes quand, assemblés, ils se proclament les enfants du Dieu tout-puissant. Car, dans un cas comme dans l'autre, ce sentiment est fait des mêmes impressions de sécurité et de respect qu'éveille, dans les consciences individuelles, cette grande force morale qui les domine et qui les soutient, et qui est la force collective (DURKHEIM, 1912, p. 553-554; grifo nosso).

Em sua interpretação, Durkheim considera os ritos miméticos os mais elementares e, precisamente por essa razão, sustenta que eles contém em germe todos os elementos que constituem a ação ritual. Nesse sentido, a execução dos atos mimetizando os animais é o meio pelo qual os membros do clã traduzem figurativamente sua identidade com a 
espécie totêmica, considerada sua congênere. Tal como acontece entre os australianos, proclamar-se filho do deus onipotente implica a execução de um conjunto de atos que mimetizam as ações ou as prescrições do deus e, ao fazer isso, criam o parentesco entre os fiéis e deus. Em ambos os casos, os procedimentos de figuração traduzem os sentimentos de altivez, confiança e veneração suscitados pelo contato com a força coletiva produzida durante a congregação. Os ritos são, portanto, meios de ação figurada pelos quais o grupo cria e recria periodicamente o poder social que lhe é subjacente.

Dessa maneira, além de ajudarem a compreender a natureza das cerimônias religiosas, os ritos também põem em evidência o caráter estético das formas de expressão religiosa. Longe de ser apenas um ornamento dispensável e superficial, Durkheim sustenta que "le culte a quelque chose d'esthétique" (DURKHEIM, 1912, p. 546). Ainda que os ritos não tenham uma função puramente lúdica, Durkheim assinala que a arte tem uma função ritual, qual seja, a de expressar figurativamente o contato dos participantes com o poder sagrado do grupo:

C'est un fait connu que les jeux et les principales formes de l'art semblent être nées de la religion et qu'elles ont, pendant longtemps, gardé un caractère religieux. [...] En effet, bien que, comme nous l'avons établi, la pensée religieuse soit tout autre chose qu'un système de fictions, les réalités auxquelles elle correspond ne parviennent cependant à s'exprimer religieusement que si l'imagination les transfigure. [...] Il a fallu que les impressions réellement ressenties par les hommes et qui ont servi de matière première à cette construction aient été interprétées, élaborées, transformées jusqu'à devenir méconnaissables. [...] D'ailleurs, parce que les forces intellectuelles qui servent à le faire sont intenses et tumultueuses, l'unique tâche qui consiste à exprimer le réel à l'aide de symboles convenables ne suffit pas à les occuper. Un surplus reste généralement disponible qui cherche à s'employer en cuvres supplémentaires, superflues et de luxe, c'est-à-dire en œuvres d'art. Il en est des pratiques comme des croyances. L'état d'effervescence où se trouvent les fidèles assemblés se traduit nécessairement au dehors par des mouvements exubérants qui ne se laissent pas facilement assujettir à des fins trop étroitement définies. [...] On voit ceux-ci sauter, tourner, danser, crier, chanter, sans qu'il soit toujours possible de donner un sens à cette agitation (DURKHEIM, 1912, p. 544-545; grifo nosso).

De acordo com Durkheim, a arte está intimamente conectada tanto às ideias quanto às práticas religiosas, e cumpre fundamentalmente duas funções rituais. A primeira diz respeito aos estados de efervescência coletiva, cuja força sagrada, intensa e tumultuosa, é produzida em abundância; um dos efeitos desse excedente de energia é o êxtase dos 
presentes, que inviabiliza a simples adequação utilitária dos símbolos exteriores e leva, ao contrário, os participantes a exteriorizarem esse êxtase necessariamente sob a forma de performances dramáticas e exuberantes tais como berros, cantos, danças e saltos. Como corolário da primeira, a segunda função ritual da arte liga-se ao caráter ideal da força sagrada, que se exprime por meio do trabalho criativo da imaginação relativo à transfiguração das impressões e dos sentimentos experimentados em ideias e práticas estéticas que dramatizam o luxo dessa força social criada coletivamente. Sejam essas formas de figuração pictóricas ou dramáticas, Durkheim sustenta que esses modos de expressão estética originam-se no seio dos rituais e estão ligados à figuração dramática do poder criativo das coletividades. Sendo assim, os rituais elementares manifestam a ligação intrínseca entre as formas estética e social (WATTS MiLler, 2013, p. 24), e podem ser qualificados como fenômenos de estética total, isto é, "a combination of art forms in a participatory collective event such as sacred drama, and in which the fundamental criterion of aesthetics is creative energy and power" (WATTS MiLlER, 2012a, p. 149-150).

$\mathrm{Na}$ conclusão, Durkheim elabora algumas reflexões mais gerais a respeito da relação entre religião e sociedade. Por um lado, os fenômenos religiosos sublinham o caráter ideal da sociedade, ligado mais à imaginação e à desejabilidade dos ideais morais do que à sua dimensão empírica apreendida pelos sentidos. Ora, vimos que o sagrado é justamente esse elemento que é acrescentado ao real durante os estados de eferverscência e cria um mundo ideal. Tal como a teodiceia religiosa da vitória do bem sobre o mal, o ideal de sociedade aspira a uma sociedade perfeita na qual a justiça e a verdade triunfariam sobre o mal. Mais precisamente, a sociedade é "une simple idée qui vient traduire dans la conscience nos aspirations plus ou moins obscures vers le bien, le beau, l'idéal'(DuRKHEIM, 1912, p. 600-601). Sendo assim, a sociedade não é constituída apenas das pessoas reunidas mas, antes, da ideia que ela faz de si mesma, pois uma sociedade "ne peut ni se créer ni se recréer sans, du même coup, créer de l'idéal" (DurKhEIM, 1912, p. 603). Não obstante, esse caráter ideal da sociedade também é manifesto em sua contribuição direta à gênese do pensamento conceitual, em que a sociedade conforma a categoria de totalidade, considerada sua forma mais abstrata que abrange as demais categorias coletivas - como as de espaço, de tempo e de força (DURKHEIM, 1912, p. 629-631). Por outro lado, a predileção atribuída às crenças 
como elemento essencial da religião é produto de um viés intelectualista equivocado das teorias predecessoras. Para Durkheim, o desenvolvimento do pensamento conceitual é um produto não negligenciável, mas secundário, do desenvolvimento dos fenômenos religiosos: "Le culte n'est pas simplement un système de signes par lesquels la foi se traduit au dehors, c'est la collection des moyens par lesquels elle se crée et se recrée périodiquement" (DURKHEIM, 1912, p. 596). Por conseguinte, a verdadeira função da religião não é fazer pensar ou enriquecer o conhecimento, mas, antes, propiciar meios de ação coletiva. Na resenha da obra publicada no Année do ano seguinte, Durkheim e Mauss concluem que a religião é, sobretudo, "un système d'actes qui ont pour objet de faire et refaire perpétuellement l'âme de la collectivité et des individus. Bien qu'elle ait un rôle spéculatif à jouer, sa fonction principale est dynamogénique" (DURKHEIM; MAUSS, 1913, p. 98; grifo nosso). Nesse sentido, a dinamogenia sublinha o poder da ação coletiva de fazer e refazer tanto as ideias quanto as práticas sociais, uma vez que "les idées et les sentiments collectifs ne sont possibles que grâce à des mouvements extérieurs qui les symbolisent" (DURKHEIM, 1912, p. 598). Assim, Durkheim concebe a sociedade como "le plus puissant faisceau de forces physiques et morales" (DURKHEIM, 1912, p. 637), sendo ela a única fonte de poder capaz de criar e transformar as ideias e práticas por meio da ação ritual. Vista dessa maneira, a religião "paraît appelée à se transformer plutôt qu'à disparaître" (DURKHEIM, 1912, p. 615).

\subsection{A dinamogenia para além do domínio religioso}

Nas oportunidades de divulgação de Les formes élémentaires de la vie religieuse, Durkheim enfatizou o que considerava ser a grande contribuição de seu livro, a saber: o caráter dinamogênico da religião, caracterizado por propiciar a ação por meio da produção e do contato com a força social nos meios rituais (DURKHEIM, 1913, p. 66-68; DURKHEIM, 1914, p. 217-218). A dinamogenia permitiria, portanto, corrigir a visão intelectualista das teorias dominantes e situar os fenômenos religiosos no domínio da ação coletiva. Não obstante, a abordagem assimilada por Durkheim ao longo da escrita do livro e que tornou possível tal resultado extrapolou o domínio estritamente religioso e repercutiu nos tradicionais domínios de interesse do autor: a educação, o direito, a moral e o conhecimento. Apesar de não ter publicado em vida nenhuma outra obra que desse continuidade à abordagem desenvolvida em Les formes élémentaires de la vie 
religieuse, os cursos ministrados por Durkheim durante o período carregam traços dessa nova abordagem que nos permitem vislumbrar seu alcance no âmbito do projeto mais amplo do autor.

Em relação ao conhecimento, Durkheim ministrou em 1913-1914 o curso sobre o pragmatismo, reconstituído a partir das anotações de estudantes e publicado em 1955. Nesse curso, Durkheim destaca o problema dos diferentes tipos de verdade - mitológica e científica - e seus respectivos papéis sociais no desenvolvimento do pensamento humano. De maneira geral, as verdades mitológicas são um conjunto de ideias coletivas, comuns e unânimes que se impõem ao espírito e são aceitas sem serem submetidas à verificação. Os mitos são objetivos e mantém uma relação com o real, pois expressam forças de origem coletiva, mas tal expressão da realidade é realizada apenas de maneira indireta e figurada. Conforme afirma Durkheim: “C'est parce que la société s'exprime au moyen des choses qu'elle est amenée à transformer, à transfigurer le réel" (DURKHEIM, 1955, p. 177; grifo nosso). Com efeito, o caráter figurado da mitologia permite compreender a variabilidade social da verdade, ou seja, compreender como as cosmologias diferem entre os povos e podem, ainda assim, ser consideradas igualmente verdadeiras porque desempenham o mesmo papel social. Enquanto as verdades mitológicas transfiguram as ideias que a sociedade faz dela mesma, as verdades científicas, apesar de também serem coletivas, expressam a realidade de maneira direta, ou, como diz Durkheim: "les vérités scientifiques expriment le monde tel qu'il est" (DURKHEIM, 1955, p. 178). No entanto, os conceitos científicos são mais acurados porque eles depuram os elementos intelectuais e os separam dos sentimentos que nos impelem a agir; consequentemente, "[1] concept enfin a un pouvoir moteur très faible" (DURKHEIM, 1955, p. 169). Em contraste, os mitos são tomados como verdadeiros não por sua conformidade com o real, "mais en raison de son pouvoir créateur" (DuRKHEIM, 1955, p. 173; grifo nosso). Se as ideias científicas não têm força sobre a consciência coletiva e nem poder para direcionar a ação - pois a sociedade não pode basear-se na dúvida metódica para viver, tampouco "attendre que ses problèmes soient résolus scientifiquement"; afinal, a sociedade "est obligée de se décider sur ce qu'elle doit faire; et, pour se décider, il faut bien qu'elle se fasse une idée sur ce qu'elle est" (DURKHEIM, 1955, p. 184) -, as ideias mitológicas traduzem de maneira inteligível para a consciência comum do grupo os sentimentos e o poder social, isto é, os elementos 
indispensáveis à ação. Apesar do otimismo de autores como Comte a respeito da superação das ideias mitológicas pelas científicas, Durkheim sustenta que haveria uma inevitável e necessária sobrevivência das representações mitológicas na vida social, mesmo onde esta seja predominantemente laica. Conforme o autor:

Or, ce qui caractérise ces représentations mythologiques, c'est qu'elles expriment une conception unanime, et c'est ce qui leur confère une force, une autorité qui fait qu'elles s'imposent, qu'elles sont soustraites au contrôle et au doute. C'est ainsi qu'ont cours dans nos sociétés des formules que nous nous imaginons n'être pas religieuses, qui ont cependant le caractère des dogmes et qu'on ne discute pas. Telles sont les notions de démocratie, de progrès, de lutte des classes, etc. Nous voyons ainsi que la pensée scientifique ne peut régner seule. Il y a, il y aura toujours, dans la vie sociale, place pour une forme de vérité qui s'exprimera peutêtre sous une forme très laïque, mais qui aura malgré tout un fond mythologique et religieux. Il y aura, pendant longtemps encore, dans toute société, deux tendances : une tendance vers la vérité objective et scientifique, et une tendance vers la vérité aperçue du dedans, vers la vérité mythologique (DURKHEIM, 1955, p. 184).

De acordo com o trecho citado, as verdades mitológicas expressam uma unanimidade que lhes confere força e as protege contra tentativas de controle e verificação. No entanto, embora essa concepção de verdade pareça se referir apenas às sociedades elementares e predominantemente religiosas, Durkheim sustenta que as verdades mitológicas persistem nos dogmas inquestionáveis de qualquer sociedade considerada laica, limitando a margem de influência do pensamento científico. Que ideias como as de democracia, progresso ou lutas de classes sejam ou tenham sido consideradas sagradas para as sociedades secularizadas, não chega a ser uma novidade para Durkheim. Já a posição de que tais ideias laicas são sobrevivências mitológicas e, portanto, representações figuradas ao invés de transparentes, certamente constitui uma novidade que contrasta com a visão sobre a Revolução Francesa apresentada en passant em seu livro anterior. Nesse sentido, a nova posição distingue com clareza a relação intrínseca e a priori da transfiguração com a ação social, por um lado, e a da transparência com a reflexão científica a posteriori, por outro. Se a ação social se orienta por ideias que transfiguram o real, cabe à ciência social dissecar esses elementos e elaborar ideias transparentes expressas sob a forma de conceitos que traduzam o mundo social tal qual ele é. Na visão evolucionária de Durkheim, a forma elementar da sociedade é precisamente aquela na qual "toute réalité est une concentration d'énergies de toutes sortes, indivises en ce sens qu'elles ne sont alors que des aspects divers d'une 
seule et même chose", ao passo que o processo de secularização "consiste en une séparation progressive de toutes ces fonctions diverses et cependant primitivement confondues" (DURKHEIM, 1955, p. 192). Para Durkheim, portanto, o processo de secularização conduz à decomposição e à segmentação do poder social em diferentes formas e funções, o que tende a intensificar a tensão e a dificultar a coordenação entre tendências conflitantes.

Em relação à educação, Durkheim ministrou de 1904 até 1914 um curso acerca da história do ensino na França, curso este que foi reconstituído a partir de dois manuscritos: um, de 1905 e outro, sem data. O curso teve a primeira edição em livro em 1938, e objetivou analisar a origem e as transformações históricas tanto do sistema de organização do ensino quanto do ideal pedagógico que o orienta. Em grande medida, o curso propõe uma crítica da whig history renascentista em relação ao legado medieval e à escolástica. Situado o início da discussão durante o período de expansão do Império Romano entre os povos germânicos, Durkheim afirma que a Igreja foi o canal pelo qual "la vie intellectuelle de Rome se transfusa peu à peu dans les sociétés nouvelles qui étaient en voie de formation. Et ce fut précisément par l'enseignement que se fit cette transfusion" (DURKHEIM, 1938, p. 26; grifo nosso). À diferença das religiões pagãs, ser cristão significa sobretudo criar uma nova disposição ou ponto de vista sobre o mundo que não pode ser assimilado senão pelo ensino; a prédica, uma prática desconhecida na Antiguidade, foi apropriada pela Igreja e passou a ter um papel preponderante desde então. "Le christianisme consiste essentiellement dans une certaine attitude de l'âme, dans un certain habitus de notre être moral. Susciter chez l'enfant cette attitude, tel sera donc le but essentiel de l'éducation" (DuRKHEIM, 1938, p. 37). Nesse sentido, as ordens monásticas cristãs conformavam ativos propagadores da fé e, ao lado dos mosteiros, nasceram as escolas de catequização que ofereciam uma educação ao mesmo tempo religiosa e profana. Tais escolas constituem, para Durkheim, a instituição elementar a partir da qual derivou todo o sistema de organização escolar francês até o presente: "Écoles cathédrales, écoles claustrales, voilà le genre bien humble et bien modeste d'où est sorti tout notre système d'enseignement" (DURKHEIM, 1938, p. 31). Mas é o século XI que Durkheim assinala como "un des moments où l'esprit humain a été le plus en effervescence, en gestation de nouveautés" (DURKHEIM, 1938, p. 95). Para o autor, tal superexcitação coletiva englobou todos os povos europeus e as cruzadas são a 
expressão desse excesso de energia disponível e da consequente necessidade de ação característicos das épocas criadoras, que moveu massas de senhores e populares ao redor da Europa em um momento de enfraquecimento das nacionalidades e fortalecimento de uma espécie de cosmopolitismo interno ao mundo cristão. Ora, esse excedente de forças que vai além do necessário para a reprodução da vida é justamente o que se transforma nas formas de expressão desse luxo, ou seja, na arte, na ciência e nos estudos (DURKHEIM, 1938, p. 86). A esse respeito, o problema dos universais foi o que caracterizou a reflexão escolástica durante a Idade Média e o que constituiu o ideal de ensino desta. Mais especificamente, é difícil entender como questões tão abstratas e distantes para nós a respeito dos universais como, por exemplo, "si, en dehors des individus humains, il existe ou non quelque principe abstrait de l'humanité, en dehors des animaux quelque principe abstrait de l'animalité” (DURKHEIM, 1938, p. 93), podem ter gerado paixões tão violentas. Devido a esse estímulo acentuado da atividade intelectual por toda a Europa, seguido da concentração dessa atividade em pontos específicos, é que "sortira cette organisation universitaire, où s'élaborera vraiment la civilisation médiévale, et qui, tout en se transformant, devait se perpétuer jusqu'à nous" (DURKHEIM, 1938, p. 90-91). As universidades são a expressão material da revolução intelectual promovida pela escolástica, a saber: a introdução da razão no dogma e, ao mesmo tempo, a recusa de negar o dogma (DURKHEIM, 1938, p. 95). Ao contrário da paz de espírito e quietude atribuída à Idade Média, Durkheim sustenta que os homens dessa época foram marcados pela seguinte contradição: de um lado, o respeito à tradição e ao desejo de manter-se fiel à Igreja; de outro, a atração do livre exame e a crescente necessidade de reflexão.

Por fim, em relação à moral e ao direito, Durkheim ministra o curso sobre a física dos costumes e do direito em diferentes momentos da carreira, de 1890 até 1912. O curso foi reconstituído a partir de manuscritos não datados e publicado em $1950^{11}$. Merece destaque aqui a análise sobre as gêneses do direito de propriedade e do direito contratual. Em relação ao direito de propriedade, Durkheim sustenta que a coisa apropriada não é mais que um tipo particular de coisa religiosa, pois também partilha do caráter contagioso do sagrado e demanda, por essa razão, interdições rituais que a separam das coisas profanas. "La propriété est contagieuse”, afirma Durkheim (1950, p.

11 O curso foi possivelmente ministrado entre 1904 e 1912 em Paris. Segundo Georges Davy, se trata de "un cours inédit d'Emile Durkheim, professé par lui à la Sorbonne” (DURKHEIM, 1950, p. V). 
175), pois são operações rituais que tanto a consagram àqueles que performam esses ritos quanto a protegem de abusos e usurpações, considerados sacrilégios. Tomando como exemplo a propriedade fundiária, considerada a forma mais elementar de propriedade, Durkheim afirma que ela nasce no seio do clã, no momento em que as famílias se apropriam de parcelas do território sagrado do grupo. De maneira análoga ao que acontece com os sacrifícios agrários, a cerimônia de demarcação recorre à consagração de um animal que percorre os limites do solo para, em seguida, ser sacrificado e derramar seu sangue ao redor do local, tornando-o próprio para a apropriação humana e protegido contra incursões externas. Dessa maneira, o rito sacrificial estabeleceu um vínculo sagrado entre a terra e os homens, dando origem ao direito de propriedade: "parce que les choses sont naturellement sacrées, c'est-à-dire appropriées par les dieux, qu'elles ont pu être appropriées par les profanes” e, portanto, a fonte do respeito à propriedade é "extérieure à la personne" (DURKHEIM, 1950, p. 186187). Assim, se as religiões "traduisent, sous forme symbolique, des nécessités sociales, des intérêts collectifs", da mesma maneira, "les croyances religieuses que nous avons trouvées à la base du droit de propriété recouvrent des réalités sociales qu'elles expriment métaphoriquement" (DURKHEIM, 1950, p. 189-190; grifo nosso). Nesse sentido, Durkheim sustenta que os deuses servem de "emblèmes à la collectivité" ou, mais precisamente, eles figuram "des forces collectives incarnées, hypostasiées sous forme matérielle" (DURKHEIM, 1950, p. 190; grifo nosso). No caso do caráter religioso do solo, ele é o emblema de expressão do poder social que fundamenta a propriedade familiar. Sob esse regime de propriedade coletiva, o caráter sagrado da terra sobressaía em relação àqueles que a exploravam, e a sociedade doméstica gozava de uma espécie de homogeneidade democrática. Foi somente quando um dos membros do grupo familiar se destacou e personificou a autoridade moral e religiosa do grupo - como foi o caso do patriarca romano - que o direito de propriedade também se personalizou e passou a ter como correspondente o proprietário individual. Nesse sentido, foi com o "l'avènement du pouvoir paternel et, plus spécialement du pouvoir patriarcal, que cette transformation s'accomplit" (DURKHEIM, 1950, p. 195; grifo nosso).

Produto da transmissão da força sagrada das coisas para o indivíduo, a passagem da propriedade coletiva à individual constitui o novo fundamento do direito de propriedade. Nesse sentido, o individualismo implica, além da liberdade de ação, a 
existência de um conjunto de coisas das quais o indivíduo pode dispor à vontade, que é precisamente o que caracteriza propriedade individual. Ao afirmar que "la propriété individuelle est chose sacrée, on ne fait donc qu'énoncer sous forme symbolique un axiome moral incontestable ; car la propriété individuelle est la condition matérielle du culte de l'individu" (Durkheim, 1950, p. 202; grifo nosso). Para Durkheim, a propriedade privada é o emblema material que figura o caráter sagrado da pessoa no individualismo moderno. A partir de então, é graças à pessoa que a força sagrada é transmitida às coisas, e essa transmissão é realizada por meio dos contratos firmados entre as partes. Durkheim investiga a origem da obrigação contratual nos ritos de afirmação da vontade, tais como os juramentos e invocações, em que pronúncia solene de determinas palavras torna os seres religiosos seus fiadores. Essa é a origem dos contratos solenes, que obriga as partes a se comprometerem de acordo com a fórmula solenemente recitada. Segundo Durkheim, não é difícil reconhecer o caráter das fórmulas mágico-religiosas neste ponto, pois é somente "la parole religieuse qui ait cette action sur les choses et sur les hommes” e, dessa maneira, “[1]a formule juridique n'est qu'un succédané du formalisme religieux", (DURKHEIM, 1950, p. 214). Sem solenidade não há contrato, pois é o ato de recitar a fórmula que cria o vínculo de obrigação entre as partes. Tanto para os Germânicos quanto para os romanos, as fórmulas rituais que selavam os compromissos contratuais eram nada mais que fórmulas de consagração (DURKHEIM, 1950, p. 218-219). Não obstante, o contrato solene persiste sempre que se faz necessário vincular tanto as partes quanto a sociedade transfigurada na forma divina, como é no caso do casamento. Para Durkheim, o casamento é um contrato solene porque esse tipo de vínculo não pode ser abandonado ao sabor dos contratantes e demanda, ainda, que "un pouvoir moral qui lui est supérieur vienne se mêler à la relation qui se forme" (DURKHEIM, 1950, p. 229). O contrato consensual nasce do contrato solene, mas o surgimento do contrato consensual não garante, por si só, que este não possa servir como meio de exploração ou de coação de uma das partes contratantes - o que entra em conflito com o sentimento de respeito pela pessoa característico do individualismo moral. A partir de então, não basta "que le contrat soit consenti, il faut qu'il soit juste" (DURKHEIM, 1950, p. 248). Do contrato consensual, Durkheim aponta o surgimento de uma nova forma contratual: a equitativa, que estipula que o contrato só deve ser reconhecido e sancionado pela sociedade sob a condição de 
ser justo. Nesse sentido, a exigência de justiça nos contratos visa despojá-los, tanto quanto possível, de todas as desigualdades ligadas ao acaso do nascimento e da condição familiar. Nesse sentido, o desenvolvimento do direito contratual acarreta numa transformação da moral em torno do direito de propriedade: desde a emergência do ideal de justiça, a distribuição das coisas entre as pessoas só é justa quando é proporcional ao mérito de cada um; portanto, "[1]a propriété des particuliers doit être la contrepartie des services sociaux qu'ils ont rendus" (DURKHEIM, 1950, p. 252). Vista sob essa perspectiva, a persistência do direito de herança se torna essencialmente injusta e só desaparecerá a partir do momento em que as desigualdades econômicas entre as pessoas deixem de ser determinadas pelo nascimento e sejam, antes, determinadas pelo fruto do trabalho de cada um. Consequentemente, "le principe qui est la base des contrats équitables étend son action au-delà du droit contractuel et tend à devenir la base du droit de propriété" (DuRKHEIM, 1950, p. 252). Para Durkheim, portanto, é somente quando o direito equitativo regula o direito de propriedade que esta última se torna o signo material ou o emblema do culto ao indivíduo.

\subsection{Conclusão}

Ao analisarmos a contribuição de Durkheim para o estudo dos fenômenos religiosos durante o período contemplado pudemos observar, por um lado, a descontinuidade da abordagem inicial da sociologie morale et juridique, centrada no estudo do funcionamento das regras de conduta por meio das sanções e interdições; e, por outro lado, a progressiva assimilação da abordagem da sociologie religieuse, centrada no estudo da gênese das ideias e práticas coletivas nos meios rituais a partir do curso de 1906-1907 sobre a origem da vida religiosa. Essa transformação culminou, para Durkheim, na publicação de Les formes élémentaires de la vie religieuse, expressão máxima da colaboração entre os pesquisadores do Année. Apesar de ter inicialmente negado a relevância dos elementos estéticos e dos símbolos religiosos para o conhecimento objetivo da realidade social, Durkheim, afinal, aderiu e deu continuidade à teoria do drama sagrado elaborada por seus colaboradores, sublinhando o caráter afetivo e estético da ação ritual, bem como seu poder de criar e transformar ideais. Tomando a relação entre mito e rito como a unidade de análise, o autor estabelece seu quadro interpretativo a partir das noções de figuração, poder e ritmo. A noção de força- 
ou poder - sui generis, anônima e impessoal - tal como a de mana ou de sagrado caracteriza-se pelo conjunto de elementos afetivos e intelectuais que conformam os ideais coletivos. Estes, por sua vez, são expressos por meio das figurações, isto é, pelas expressões estéticas do poder social produzidas especialmente para as cerimônias religiosas: grafismos, emblemas e pinturas corporais, bem como ritmo, performances cênicas, cantos e danças. A esse respeito, Durkheim dedica-se especialmente à análise dos emblemas, que consistem em figurações visuais e materiais da força coletiva sob a forma de grafismos, brasões ou bandeiras. A combinação entre os modos de figuração e a manipulação do poder sagrado é caracterizada pelos estados de efervescência coletiva, que têm por efeito a criação de novos ideais e, consequentemente, de novas realidades. Dessa maneira, é a partir da interação entre a força social sui generis e as formas estéticas de expressão que a ação ritual produz as sucessivas transfigurações de ideias, práticas e sentimentos coletivos, fazendo da transformação um de seus efeitos inerentes. Tal capacidade da ação ritual de criar e transformar tantos as ideias quanto as práticas sociais constitui a dinamogenia, definida como a capacidade intrínseca dos fenômenos religiosos de propiciar a ação coletiva e a transfiguração das forças sociais em ação. Com efeito, a ação ritual extrapola o domínio religioso e passa a figurar no centro das análises de Durkheim acerca da gênese e do desenvolvimento das ideias e práticas sociais, constituindo o modelo elementar de ação social.

Nesse sentido, o desenvolvimento da reflexão de Durkheim ao longo desse período revela uma mudança em sua compreensão acerca dos fenômenos religiosos, bem como a maturação de uma nova abordagem. Do ponto de vista do objeto de análise, Durkheim deixa de lado a predileção pelas sociedades com escrita e, particularmente, pelos hebreus como modelo de sociedade primitiva, e passa a considerar os documentos etnográficos das sociedades indígenas, particularmente dos povos australianos, como meio privilegiado de acesso às formas elementares dos fenômenos sociais. Do ponto de vista metodológico, Durkheim abandona a identificação das sanções e das interdições em favor dos ritos e mitos com símbolos exteriores que permitem o conhecimento objetivo dos fenômenos religiosos. Nesse sentido, a noção mesma de símbolo acaba por se transformar: anteriormente considerado como índice, isto é, como conjunto de signos inequívocos e passíveis de mensuração, o símbolo passa a ser concebido como imagem, ou seja, como formas expressivas ou de significação. Do ponto de vista teórico, 
Durkheim deixa de lado a investigação do funcionamento das regras de conduta, ligada à dimensão do dever, em favor da análise da gênese dos ideais coletivos nos meios rituais, sublinhando o caráter ideal e desejável desses fenômenos. Tomando a unidade formada entre mito e rito, Durkheim encontra na linguagem estética e afetiva da ação ritual o meio de produção da força sagrada e a consequente transfiguração de seres e coisas envolvidos nesses meios efervescentes. A sociedade passa a ser concebida como um feixe de forças que tem no meio ritual o locus de produção e transformação das ideias e práticas coletivas. Tal mudança possibilitou, dentre outras coisas, uma reconfiguração do papel da religião na vida social: antes considerada apenas uma forma de disciplina social, a religião se torna o domínio por excelência da ação social criativa e transformadora, que tem no vasto simbolismo sua forma de expressão. Por fim, do ponto de vista evolucionário, Durkheim mantém a relação entre morfologia e fisiologia, considerando o totemismo como a religião do clã; por outro lado, no que concerne à dinâmica da vida coletiva, passa a conceber a lei do ritmo da vida coletiva a partir da alternância cíclica entre os tempos sagrado e profano, de concentração e dispersão. $\mathrm{O}$ decurso da evolução religiosa é, então, marcado pela tendência crescente de diferenciação, espiritualização e individualização das crenças e práticas religiosas, acompanhando a tendência de diferenciação e individualização do meio social em geral.

Não obstante, a visão de Durkheim se modifica substancialmente a respeito tanto i) da relevância dos símbolos religiosos para a análise sociológica, quanto ii) da relação da Sociologia com o Esclarecimento. Se antes o autor considerava mitos, ritos e a parafernália simbólica como invólucros superficiais a serem progressivamente abandonados durante o processo de secularização, agora, Durkheim reconhece a perenidade dos mitos e ritos, considerados como formas elementares das ideias e práticas coletivas. Em sua visão reformada da vida moderna, mesmo os fenômenos sociais considerados laicos, como as revoluções, os ideais políticos e tudo aquilo que a sociedade cria de novo não são senão produto da linguagem estética e afetiva da ação ritual e da consequente transfiguração da realidade subjacente. Isso é particularmente evidente em seus cursos, seja acerca distinção entre as verdades mitológicas e as verdades científicas, seja pela caracterização da propriedade privada como símbolo do culto ao indivíduo. Assim, as representações transparentes seriam, na melhor das hipóteses, um conhecimento de segunda ordem produzido por cientistas - juízos de fato 
expressos na forma de conceitos, distintos dos juízos de valor produzidos pelo homem comum nos períodos de eferverscência coletiva. Ao reconhecer a transfiguração como parte inerente da vida social, Durkheim adere à proposta da sociologie religieuse, qual seja: a de uma sociologia da transfiguração como um caminho tanto de compreensão científica e transparente do mundo social, quanto de crítica da autocompreensão da sociedade moderna sobre o Esclarecimento. Mais precisamente, a sociologia da transfiguração possibilitou que Durkheim criticasse o Esclarecimento enquanto um dogma que coroa o papel da ciência na condução da racionalização da vida e a opõe às demais formas de compreensão do mundo social, consideradas puras formas de mistificação. Nesse sentido, investigar "forms of transfiguration as transparence [...] is also to drop the dogma of conceptual reason as the one and only path to enlightenment" (WATts Miller, 2012a, p. 155). Em sua forma desmistificada, o ideal de Esclarecimento significa, para Durkheim, a integração entre la vie sérieuse e la vie réjouissante em uma espécie de pluralismo que advoga um processo contínuo de abertura para outras formas conhecimento do mundo. Nesse sentido, a sociedade moderna e seus produtos, incluindo a ciência, são agora concebidos como apenas uma variante do processo mais amplo de maturação da razão que perpassa, necessariamente, todas as sociedades e seus respectivos produtos culturais.

Enfim, a assimilação e o desenvolvimento da sociologie relieuse por Durkheim significou, precisamente, a incontornável influência dos trabalhos dos verdadeiros criadores da nova abordagem sobre o pensamento de Durkheim, a saber: Hubert e Mauss. Ao compararmos tudo aquilo que os editores da seção de sociologie religieuse do Année produziram, percebemos como Durkheim adere em todos os níveis à abordagem desenvolvida por seus colaboradores do Année, incorporando-a a sua própria reflexão e contribuindo para desenvolvê-la em tópicos até então inexplorados. Mesmo as discordâncias específicas que os autores em questão mantiveram, exemplificadas pela polêmica sobre o sacrifício, confirmam, ao invés de refutar, a adesão de Durkheim à abordagem desenvolvida em conjunto por Hubert e Mauss. A esse respeito, duas cartas endereçadas a Mauss após a publicação de Les formes élémentaires de la vie religieuse ilustram o que demonstramos até aqui. Na primeira delas, Fauconnet comenta o seguinte: “Je m'attends, à un beau livre de Durkheim [...] Il emprunte ton sujet et dans qq. mesure, la méthode comparative. C'est une preuve de notre influence. J'ai trouvé 
qu'il était un peu trop habile à présenter cette méthode comme la sienne" ${ }^{12}$. Apesar de não termos a resposta de Mauss, a carta de Fauconnet nos informa a respeito de duas questões: a crença da equipe do Année na influência do grupo sobre o pensamento de Durkheim; e, sobretudo, a habilidade de Durkheim em apresentar a abordagem desenvolvida por Hubert e Mauss como produto de seu próprio desenvolvimento intelectual. Já na segunda carta, é Hubert quem comenta sobre o novo livro de Durkheim: "J'ai reçu le bouquin de Durkheim. Il m'y manque un peu ta signature, car ta part est grande. Je t'en parlerai bientôt" (HUBERT; MAUSS, 2021, p. 224). Em seguida, Mauss responde de maneira evasiva ao questionamento de Hubert: "Quant au livre de l'oncle, crois-moi, il y a beaucoup de lui : et ses audaces, et cette courte haleine dans l'exposé des faits sont bien de lui" (HuBERT; MAUSS, 2021, p. 225). Se, por um lado, a carta de Hubert lança uma enigmática suspeita de coautoria de Les formes élémentaires de la vie religieuse, Mauss responde, sem negar sua participação no projeto, que a obra tem, igualmente, muito do estilo de Durkheim - notadamente, o fôlego curto na exposição do fatos e a audácia das conclusões. Para além disso, a resposta de Mauss demonstra dois traços perenes de sua colaboração com Durkheim: por um lado, o comprometimento incondicional do sobrinho com o projeto intelectual do tio; por outro, a clareza de que, apesar da profunda interlocução, seus projetos intelectuais não se confundem.

12 Carta de Paul Fauconnet a Marcel Mauss, sem data [1912], Fonds Hubert-Mauss, Collège de France. 


\section{Conclusão. Repensando a sociologia durkheimiana da religião}

Este estudo realizou uma análise sistemática e crítica da gênese e desenvolvimento da sociologia durkheimiana da religião a partir da colaboração entre Durkheim, Hubert e Mauss ao longo da primeira série do Année sociologique. Sob esse novo ângulo, nosso percurso resultou em uma imagem significativamente distinta daquela que é comumente disseminada acerca da sociologia durkheimiana da religião e da colaboração entre os membros do Année. Como conclusão, pretendemos discutir essa nova imagem e suas implicações em três frentes distintas. Discutiremos, no que se refere à primeira delas, os problemas envolvidos na história intelectual durkheimiana, tomando como eixo a verificação das hipóteses apresentadas na introdução para explicar a mudança ocorrida na sociologia durkheimiana da religião durante o período analisado. Quando tratarmos da segunda frente, ofereceremos uma interpretação - ainda que parcial - da lógica da mudança teórica e da criação de nichos temáticos no interior da sociologia durkheimiana a partir da segmentação da tradição em dois programas de pesquisa distintos. Por fim, ao discutirmos a terceira frente apontaremos as implicações e a relevância da teoria durkheimiana da ação ritual para as ciências sociais, reconhecendoa como uma contribuição fértil mas ainda pouco explorada da sociologia durkheimiana da religião.

\section{De Hubert e Mauss a Durkheim - ou a história intelectual vista do avesso}

$\mathrm{Na}$ introdução deste trabalho havíamos apresentado duas hipóteses a serem verificadas no decurso de nossa investigação - hipóteses estas elaboradas a contrapelo das tendências de interpretação identificadas pela revisão bibliográfica. Esse contraste permitiria pôr em evidência a colaboração entre os membros do Année como a causa imediata da mudança teórica de Durkheim a respeito da religião e, assim, questionar a própria centralidade comumente atribuída a Durkheim para o empreendimento da 
sociologia durkheimiana da religião. Vejamos como a verificação de cada uma das hipóteses pode lançar uma nova luz sobre a história da sociologia durkheimiana.

$\mathbf{1}^{\mathrm{a}}$ hipótese: A transformação da abordagem sociológica da religião de Durkheim pela influência dos trabalhos de Hubert e Mauss.

A transformação da sociologia da religião de Durkheim é certamente o problema mais debatido a respeito do desenvolvimento intelectual do autor. A hipótese da influência exercida por Robertson Smith gerou um amplo debate entre especialistas, que se estendeu até a década de 1980 sem, no entanto, lograr nenhum resultado objetivo; na falta de uma resposta, o que antes configurava hipótese de trabalho passou a ser tomado como fato e a alimentar uma whig history sobre Durkheim. A verificação de nossa primeira hipótese pretendeu, então, desafiar esse consenso, oferecendo uma interpretação alternativa e factualmente adequada da transformação da abordagem sociológica da religião de Durkheim pela influência dos trabalhos de Hubert e Mauss. Como vimos, Hubert e Mauss foram responsáveis pela elaboração de uma nova abordagem no interior da sociologia durkheimiana, relacionada à emergência da sociologie religieuse como uma das especialidades do Année. Treinados e proficientes tanto em sociologia durkheimiana quanto em antropologia e história das religiões, a criação da sociologie religieuse significou muito mais que a mera acomodação da abordagem inicialmente proposta por Durkheim em um novo domínio. Tal criação exigiu de Hubert e Mauss a elaboração de uma nova abordagem capaz de resolver as anomalias enfrentadas pela abordagem inicial de Durkheim para explicar os problemas considerados relevantes para a história e antropologia das religiões e, assim, se contrapor às abordagens psicológicas e intelectualistas dominantes na área. Durkheim, por sua vez, manteve-se na tentativa de expandir o escopo de sua abordagem inicial até 1906-1907, momento em que passou a assimilar, progressivamente, a nova abordagem da sociologie religieuse e que culminou, em 1912, na publicação de Les formes élémentaires de la vie religieuse. Tal transição acarretou, como vimos, uma mudança de foco de Durkheim em vários níveis: da ênfase no dever e na disciplina à ênfase no caráter desejável e ideal dos fenômenos sociais; do método esquemático ao método genético; do caráter regulador para o caráter generativo do poder social; de uma visão lógica dos símbolos como índices para uma visão semiótica dos símbolos como 
imagens; enfim, da marginalidade à centralidade da estética para a compreensão dos mecanismos de transfiguração que constituem as formas de expressão social. Nossa tese mostrou, então, que a fonte de toda essa transformação de Durkheim não poderia ser encontrada em nenhum autor externo à tradição durkheimiana e que, ainda, ela só pode ser plenamente compreendida em relação aos trabalhos de Hubert e Mauss. Vista dessa maneira, a obra tardia de Durkheim sobre a religião é, na verdade, um dos desenvolvimentos específicos realizados no interior do projeto intelectual concebido por Hubert e Mauss à frente da seção de sociologie religiuse do Année. Esse projeto incluía, além da obra tardia de Durkheim (1912), a tese de Stefan Czarnowski (1919) sobre o culto dos heróis e a tese inacabada de Robert Hertz (1922) sobre pecado e expiação todas produzidas concomitantemente entre 1906 e a Primeira Guerra. Com efeito, a adequada compreensão da transformação da abordagem sociológica de Durkheim sobre a religião exige que reconheçamos nele, além do papel de fundador de uma tradição, um outro papel: o de um colaborador que viu em um projeto intelectual paralelo ao seu a emergência de uma nova heurística, capaz de inaugurar um fértil domínio de investigação para a sociologia durkheimiana. A transformação da abordagem de Durkheim sobre a religião se deve, portanto, à assimilação da abordagem criada por seus colaboradores do Année: Hubert e Mauss.

2a hipótese: A elaboração por Hubert e Mauss de uma teoria da ação ritual posteriormente incorporada por Durkheim.

Como corolário da primeira hipótese, a verificação de nossa segunda hipótese pretendeu oferecer caracterização mais precisa do fator da mudança teórica de Durkheim. Tal caracterização pretende ser capaz de ultrapassar a simples sugestão acerca da existência de um grupo de autores cuja produção guardaria vaga afinidade com a obra tardia de Durkheim sobre a religião. Nesse sentido, tratou-se de explicitar a teoria do drama sagrado como o núcleo articulador do arcabouço conceitual da nova abordagem elaborada por Hubert e Mauss e incorporada, em um segundo momento, por Durkheim. A teoria do drama sagrado sublinha a capacidade da ação ritual dramática de engendrar os estados emocionais de êxtase nos quais os participantes entram em contato com o poder sagrado. A combinação entre ritmo, figuração e êxtase na manipulação da força sagrada é caracterizada pelo estado de efervescência coletiva, que sublinha, por 
sua vez, a capacidade criativa da ação ritual em transfigurar as forças sociais em ação e ocasionar o advento de novas ideias e práticas coletivas. Com efeito, o drama sagrado organiza a dinâmica da vida coletiva i) do ponto de vista cíclico, pela alternância sazonal entre os períodos de vida ritual e de vida cotidiana; ii) do ponto de vista evolucionário, por meio das transformações de longa duração das ideias e práticas coletivas, cuja efetivação depende do desenvolvimento de instituições análogas situadas no meio social mais amplo. Esse breve resumo do mecanismo da ação ritual, que poderia servir para resumir também o esquema presente em Les formes élémentaires de la vie religieuse, não pode ser encontrado em nenhum autor externo à tradição durkheimiana; não obstante, foi precisamente esse mesmo mecanismo que nós vimos emergir, muito antes de ser assimilado por Durkheim, nos trabalhos de Hubert e Mauss. Além disso, Hubert e Mauss acabam por estender o escopo da ação ritual para além do domínio religioso stricto sensu, seja para investigar os sistemas de prestações totais, seja para entender o papel dos festivais e da mitologia heroica na configuração das identidades nacionais. De maneira semelhante, em seus cursos ministrados na Sorbonne, Durkheim também estende o escopo da ação ritual para além do domínio estritamente religioso, investigando a emergência da propriedade privada e do culto do indivíduo, do pensamento escolástico e do sistema universitário, bem como das verdades mitológicas e científicas. Considerado o núcleo da heurística da abordagem desenvolvida por Hubert e Mauss e posteriormente assimilada por Durkheim, a ação ritual constitui o modelo elementar de ação social, que permite entrever os processos de criação e transformação das ideias e práticas coletivas.

\section{A lógica da mudança teórica da sociologia durkheimiana}

A verificação de nossas hipóteses sugere que a criação da nova abordagem por Hubert e Mauss acarretou uma segmentação no interior da sociologia durkheimiana. Com efeito, é oportuno explicitar o esquema de análise implícito em nossa investigação e oferecer uma explicação, ainda que parcial, da mudança teórica à qual nos referimos. Retomando o instrumental de Kuhn (2000) e Lakatos (1970) apresentado na introdução, designamos a sociologia durkheimiana como uma tradição científica, isto é: uma matriz de pressupostos, linguagem, valores e regras compartilhados que orientam a resolução de problemas. Tal como estabeleceu Durkheim em seus trabalhos anteriores ao Année, a 
tradição durkheimiana caracteriza o mundo social, em seu nível mais abstrato e genérico, como um domínio independente regido por forças sui generis que submetem a conduta e o pensamento humanos às leis socais. Explicar, para Durkheim e sua tradição, significa, em última análise, decompor e reduzir os fenômenos observados a suas causas sociais últimas. Para realizar esse projeto intelectual, Durkheim concebeu uma heurística, isto é, uma abordagem inicial ou um conjunto parcialmente articulado de regras e sugestões que determina a escolha dos problemas a serem investigados em meio a um mar de anomalias e que indica, ainda, uma maneira de resolver tais problemas (LAKATOS, 1970, p. 134-137). Como vimos no primeiro capítulo, a heurística elaborada por Durkheim estabelece a moral como o núcleo da vida social, enfocando a dimensão do dever e de la vie sérieuse como aquela que constitui o conjunto de regras fundamentais para a existência e o funcionamento das sociedades. Sendo este o objeto que interessa à sua sociologia investigar, a heurística em questão estabelece, então, uma abordagem centrada na investigação do funcionamento das regras de conduta obrigatórias por meio da manifestação de seus símbolos exteriores e objetivos, como as sanções e interdições, que variam de acordo com a morfologia de cada tipo social em questão. Dessa maneira, a heurística de Durkheim estabelece a religião, a moral e o direito como formas de disciplina social que objetivam tanto a integração social quanto a regulação da conduta e do pensamento individuais. Com a criação do Année e a formação de uma equipe de jovens pesquisadores treinados em diferentes áreas das ciências sociais mas que aderiram ao projeto intelectual inaugurado pela tradição durkheimiana, Durkheim estabeleceu as condições necessárias para que sua tradição sociológica pudesse ampliar sua base empírica e criar, assim, novos nichos em seu interior. A criação dos nichos depende, por sua vez, da participação de pesquisadores bilíngues (KUHN, 2000, p. 93-100), fluentes na tradição dominante da área de origem e na tradição durkheimiana emergente, que tenham condições de adaptar a heurística desenvolvida por Durkheim para a resolução de problemas nesses domínios específicos e ampliar, assim, a capacidade de resolução de problemas da sociologia durkheimiana como um todo. De acordo com essa estratégia, os jovens pesquisadores bilíngues do Année atuavam como invasores nas tradições dominantes, objetivando se apropriar da linguagem e dos problemas da tradição vigente e convertê-los em exemplos de corroboração da tradição emergente (BIAGIOLI, 1990, p. 205-206). 
No caso específico da sociologia durkheimiana da religião, a heurística desenvolvida por Durkheim já havia estabelecido religião, moral e direito como o conjunto de forças reguladoras da sociedade, concebendo a primeira, ainda, como germe das regras de conduta sancionadas. Com a formação da equipe do Année, Mauss - que havia sido pessoalmente supervisionado por Durkheim em Boudeaux e por Léon Marillier e Sylvain Lévi na EPHE - e Hubert - historiador e arqueólogo de formação também ligado à seção de ciências da religião da EPHE - tornaram-se os editores à frente da seção de sociologie religieuse. Nesse sentido, a missão de Hubert e Mauss correspondia à dos demais jovens pesquisadores bilíngues do Année: a de se infiltrarem como invasores na área de ciência das religiões, se apropriarem da linguagem e dos problemas da área, adaptarem a heurística desenvolvia por Durkheim para resolução desses problemas e convertê-los em exemplos de corroboração, estabelecendo, enfim, um novo nicho intelectual para a tradição durkheimiana. Como vimos no primeiro e segundo capítulos, haviam boas razões para Durkheim crer que a formação do novo nicho da sociologie religieuse seria o coroamento de seu desenvolvimento intelectual anterior: além de toda a reflexão sobre a relevância da religião primitiva na conformação do dever, Durkheim já havia conjecturado, em seus cursos de 1898-1899, que o sacrifício seria o germe da instituição penal, e estava particularmente confiante que o ensaio de Hubert e Mauss sobre o sacrifício seria um passo decisivo de corroboração de sua teoria. Todavia, foi a partir desse mesmo período que as expectativas de Durkheim e as realizações de Hubert e Mauss começaram a discrepar de maneira acentuada e irreversível: Hubert, contra-argumentando Durkheim, indica que o sacrifício penal não faz sentido como ideia matriz do fenômeno sacrificial; Mauss, por sua vez, tenta dissuadir Durkheim - sem sucesso - a não publicar seu artigo sobre a definição dos fenômenos religiosos no mesmo volume de seu ensaio sobre o sacrifício. O segundo volume do Année (1899) marca, portanto, o descompasso entre as concepções de religião da antiga heurística de Durkheim e da heurística emergente de Hubert e Mauss para a sociologie religieuse.

Embora Hubert e Mauss fossem partidários da visão do mundo social como um domínio independente regido por forças sui generis, eles também estavam cientes das limitações que a heurística desenvolvida por Durkheim impunha para a resolução dos problemas prementes da área de ciência das religiões e, consequentemente, para o 
próprio desenvolvimento da sociologie religieuse. Embora reconheçam o potencial da primeira explicação sociológica da religião de Durkheim, Hubert e Mauss identificam uma limitada força heurística nessa abordagem, uma vez que os problemas cruciais da área eram problemas anômalos para a sociologia durkheimiana até então. A avaliação de Hubert e Mauss a respeito da questão pode ser ilustrada da seguinte maneira:

\section{A sociologia durkheimiana da religião antes da sociologie religieuse}

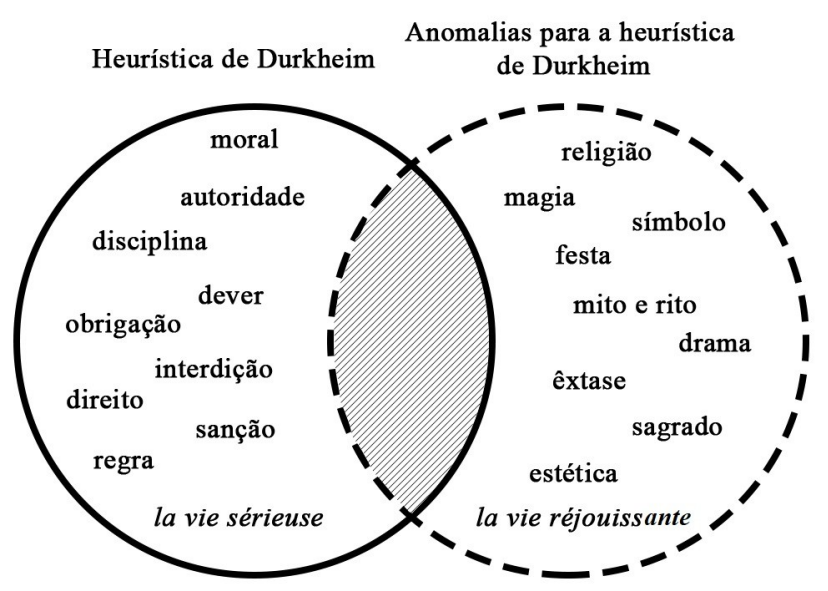

Conforme a síntese ilustrada pela figura acima, o bilinguismo de Hubert e Mauss permitiu que os autores interpretassem a heurística de Durkheim como tendo pouca força na área de ciências da religião, mesmo se fosse bem-sucedida: por um lado, os problemas ligados à estrutura lexical da heurística de Durkheim, relativos ao dever e às regras sancionadas, eram considerados marginais pela área de ciências das religiões; por outro, uma gama de problemas considerados centrais para a área se apresentavam como anomalias para a heurística de Durkheim, demandando muito mais que uma simples adaptação para resolvê-los. Como vimos no segundo capítulo, a emergência da sociologie religieuse demandou de Hubert e Mauss a elaboração de uma nova heurística, capaz de oferecer uma explicação sociológica para os problemas relevantes das ciências da religião, ou seja, capaz de converter as anomalias em exemplos de corroboração da tradição durkheimiana. Nesse sentido, a religião constitui um verdadeiro caso de problemshift para a sociologia durkheimiana, na medida em que a antiga heurística de Durkheim se torna degenerativa para a sociologie religieuse, ao passo que a nova heurística elaborada por Hubert e Mauss resulta em " $a$ theoretically progressive problemshift" (LAKATOS, 1970, p. 118). Essa transformação é atestada pelo próprio desenvolvimento intelectual de Durkheim, que posteriormente adere à nova 
heurística de Hubert e Mauss e contribui, ele mesmo, para o desenvolvimento da sociologie religieuse.

À diferença da criação dos outros nichos do Année, a emergência da sociolgie religieuse demandou a elaboração de uma nova heurística para resolver os problemas tidos como anômalos e acarretou, portanto, uma mudança teórica no interior da tradição. Diferentemente da mudança revolucionária que instituiu a sociologia durkheimiana, a mudança teórica produzida pela nova heurística da sociologie religieuse foi resultado de uma especiação ou estreitamento do foco no interior da tradição durkheimiana para tratar de problemas com os quais a heurística anterior se mostrou incapaz de lidar. Conforme assinalou Kuhn, essa revisão na estrutura lexical tem por efeito a segmentação de especialidades no interior da tradição:

The transition to a new lexical structure, to a revised set of kinds [kind terms], permits the resolution of problems with which the previous structure was unable to deal. But the domain of the new structure is regularly narrower than that of the old [...] What lies outside of it becomes the domain of another scientific specialty, a specialty in which an evolving form of the old kinds remains in use. Proliferation of structures, practices, and worlds is what preserves the breadth of scientific knowledge; intense practice at the horizons of individual worlds is what increases its depth (KuHN, 2000, p. 250).

Essa mudança teórica provocou, portanto, uma segmentação da tradição durkheimiana entre a nova heurística - criada para lidar com os problemas anômalos - e a antiga heurística - que se manteve ativa no desenvolvimento de outros nichos do Année. Assim, o processo de especialização e mudança teórica da sociologia durkheimiana pode ser ilustrado a partir do modelo kuhniano elaborado por Brad Wray (2015, p. 180):

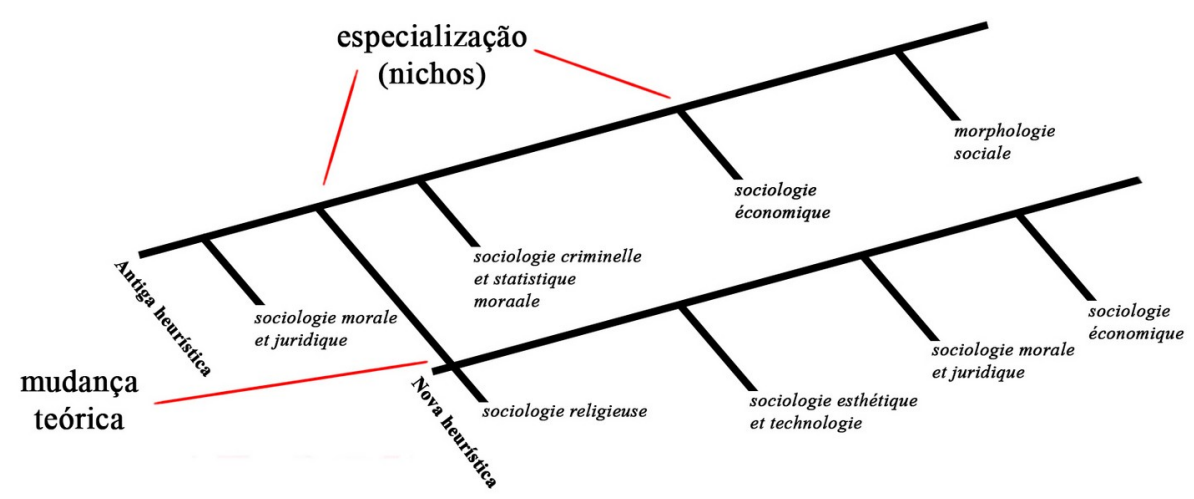


De acordo com a figura acima, o desenvolvimento da sociologia durkheimiana entre 1886 e 1915 levou a uma segmentação da tradição em duas heurísticas ou dois programas de pesquisa distintos, ambos teoricamente progressivos em seus domínios e orientados para a proliferação de seus respectivos nichos. De um lado, o programa de pesquisa da antiga heurística preservou o estudo do funcionamento das regras de conduta de um tipo social determinado por meio de seus índices: privilegiando os problemas relativos às sociedades modernas, vistas em seu contraste e descontinuidade em relação às sociedades tradicionais, o primeiro programa enfoca os processos de integração e regulação da conduta individual pela ordem social e suas instituições. De outro lado, o programa de pesquisa da nova heurística inaugurou o estudo da gênese e transformação das ideias e práticas elementares por meio de suas figurações: privilegiando o estudo dos problemas relativos às sociedades indígenas, vistas em sua congruência e continuidade em relação às sociedades modernas, o segundo programa enfoca os processos evolucionários de criação e transformação de ideias e práticas engendrados pela ação ritual em diferentes contextos civilizacionais. Com efeito, o campo semântico de cada um dos programas de pesquisa pode ser sumarizado da seguinte maneira:

\footnotetext{
A tradição durkheimiana e seus programas de pesquisa

\begin{tabular}{|c|c|}
\hline $\begin{array}{l}1^{\circ} \text { Programa de Pesquisa } \\
\text { (antiga heurística) }\end{array}$ & $\begin{array}{l}2^{\circ} \text { Programa de Pesquisa } \\
\text { (nova heurística) }\end{array}$ \\
\hline $\begin{array}{l}\text { Funcionamento dos fenômenos } \\
\text { (método esquemático) }\end{array}$ & $\begin{array}{l}\text { Gênese e desenvolvimento dos fenômenos } \\
\text { (método genético) }\end{array}$ \\
\hline Símbolo como índice & Símbolo como imagem expressiva \\
\hline $\begin{array}{l}\text { Ênfase na ordem moral } \\
\text { (poder contraignant) }\end{array}$ & $\begin{array}{l}\text { Ênfase na ação ritual } \\
\text { (poder criador) }\end{array}$ \\
\hline Sanção, obrigação, regra, autoridade & Figuração, drama, efervescência, ritmo \\
\hline $\begin{array}{l}\text { Dever moral } \\
\text { (la vie sérieuse) }\end{array}$ & $\begin{array}{l}\text { Ideal sagrado } \\
\text { (la vie réjouissante) }\end{array}$ \\
\hline $\begin{array}{l}\text { Crítica à ciência social ideológica } \\
\text { (o caminho da transparência) }\end{array}$ & $\begin{array}{l}\text { Crítica à autoimagem da sociedade moderna } \\
\text { (a inevitável transfiguração) }\end{array}$ \\
\hline
\end{tabular}

Ainda que de maneira esquemática e parcial, o quadro acima delineia os principais elementos que constituem cada um dos programas de pesquisa desenvolvidos pela tradição durkheimiana ao longo da primeira série do Année. Cada um deles circunscreve um domínio definido e independente de problemas; não obstante, ambos mantiveram-se
} 
fiéis ao núcleo de pressupostos e valores comuns que caracterizam a tradição durkheimiana, e seus enfoques podem ser considerados complementares. Da mesma maneira, a divisão entre os dois programas não está determinada pelos nichos temáticos, tendo em vista que boa parte dos nichos do Année acabaram por produzir trabalhos para ambos os programas de pesquisa - como atesta o próprio Durkheim e seus diferentes trabalhos para a sociologie morale et juridique ${ }^{1}$. De maneira semelhante, Steiner (2005) havia identificado a existência dos dois programas de pesquisa no âmbito da sociologie économique do Année: um ligado ao primeiro programa e encabeçado por François Simiand; e outro ligado ao segundo programa e encabeçado por Mauss. Caberia, ainda, observar como as gerações de alunos formados por Mauss ${ }^{2}$ durante o entreguerras contribuíram para desenvolver o segundo programa de pesquisa ao redor do mundo, caso exemplificado especialmente por figuras menos reconhecidas internacionalmente, mas que tiveram grande influência regional, tais como Roger Bastide (1958), Marcel Granet (1919), André Leroi-Gourham (1964 e 1965), Alfred Métraux (1928 e 1967) e Denise Paulme (1940 e 1956). Sem negar a dificuldade que o desenvolvimento intelectual das ciências sociais impõe, seria relevante avaliar em que medida o desenvolvimento subsequente da tradição durkheimiana nas ciências sociais pode ser deduzido dessa segmentação que estabelecemos entre os dois programas de pesquisa.

\section{A teoria durkheimiana da ação ritual contra as falsas transparências da razão}

Certa vez, Randall Collins (1995) observou que apesar de levar Durkheim em seu nome, a tradição durkheimiana desenvolveu-se fundamentalmente como uma tradição impessoal e anônima nas ciências sociais. Vimos nesta tese que, se bem compreendida, a tradição durkheimiana se desenvolveu desde o princípio como um tour de force coletivo ao qual Durkheim serviu de emblema, mas que ganhou força própria e transcendeu a consagração pessoal de qualquer um dos membros de sua primeira geração $^{3}$. Ou seja, os membros da equipe do Année serviram, ao custo da despersonalização de suas contribuições individuais, como componentes do

1 A respeito dos demais membros do nicho de sociologie morale et juridique, como Paul Fauconnet e Georges Davy, as indicações de Paul Vogt (1983, p. 192) sugerem que seus respectivos trabalhos podem ter sido realizados no âmbito do segundo programa de pesquisa.

2 A esse respeito, o Manuel d'ethnographie de Mauss (1947), livro elaborado a partir das anotações de seus alunos e que condensa suas aulas relativas ao período entreguerras, poderia ser interpretado como um manual de educação e divulgação do segundo programa de pesquisa da tradição durkheimiana. 
desenvolvimento impessoal da tradição. Não obstante, soma-se a esse quadro outra dificuldade: não raro a tradição durkheimiana também avançou anonimamente por meio do trabalho daqueles que a contestaram e, compreendendo-a adequadamente ou não, almejaram superá-la. Assim, nem mesmo a reivindicação do rótulo durkheimiano nos conduz, necessariamente, à compreensão adequada do desenvolvimento da tradição em questão. No caso da teoria da ação ritual durkheimiana, tanto os que a criticam quanto os que a reivindicam convergem, paradoxalmente, para o mesmo ponto, a saber: o de recorrer à intuição como instância privilegiada de discussão e julgamento dos equívocos e virtudes da teoria durkheimiana - em detrimento da reconstrução sistemática e argumentada dos textos dos autores. Sem a reconstrução do mecanismo da ação ritual efetivamente elaborado e utilizado pela equipe do Année, seus adversários e seguidores tardios não podem desenvolver seus argumentos senão às cegas, ratificando o desenvolvimento involuntário da tradição durkheimiana. Em direção oposta a esse movimento, propomos nesta tese um esquema interpretativo para iluminar o desenvolvimento da tradição durkheimiana para além de seus emblemas, isto é, centrando-se no estudo das estruturas lexicais e modelos de resolução de problemas de seus programas de pesquisa. Nosso esquema possibilitou identificar a emergência da teoria da ação ritual em Hubert e Mauss e, assim, questionar tanto o milagre da "revelação" quanto o peso da contribuição de Durkheim para a teoria da ação ritual. Considerando a contribuição de Durkheim nesse domínio como mais restrita que a de seus colaboradores que a criaram, pretendemos, à guisa de conclusão, sublinhar as potencialidades inauditas da teoria da ação ritual para, assim, repensar o legado da sociologia durkheimiana da religião para além de seu colaborador mais conhecido.

Tal como elaborado por Hubert e Mauss, a ação ritual constitui o modelo mais elementar e fundamental de ação social. Pensada a partir da comparação etnográfica das cerimônias religiosas de sociedades indígenas - consideradas o locus privilegiado para depreender o mecanismo em sua completude -, a ação ritual se caracteriza como uma performance coletiva de concentração e manipulação do poder social e se expressa por meio de uma linguagem rítmica, dramática e estetizante dos ritos e mitos, tendo por efeito a criação, ou mesmo a recriação, das ideias e práticas coletivas. É importante enfatizar que a ação ritual diz respeito à criação e à manipulação do poder social, termo

3 Nos raros casos nos quais houve consagração, como os de Durkheim e Mauss, esta foi somente póstuma. 
que é utilizado pelos próprios autores para traduzir as noções nativas de ideia-força ou de pensamento-ação. Sejam estas de mana ou sagrado, elas ultrapassam a realidade sensível e se dirigem à dimensão ideal da vida coletiva. Além disso, a ação ritual expressa a manipulação do poder sagrado por meio de uma linguagem coletiva e estetizante, que prima pelos aspectos alegóricos das performances dramáticas e visuais. Para os autores, essas formas de expressão figurativas constituem a linguagem por excelência do pensamento e ação coletivos. Esse esquema estabelece uma origem hipotética da ação ritual nas grandes festas religiosas, públicas e periódicas das sociedades indígenas. A partir dessas festas, consideradas a matriz das ideias e práticas coletivas, a ação ritual configura todo o conjunto de relações do grupo: entre si, com o cosmos e com os outros grupos, humanos e não-humanos. Além disso, a ação ritual extrapola o domínio das relações estritamente sagradas e passa a intermediar todo o conjunto de relações potencialmente impuras e perigosas, de tal maneira que sua linguagem pode ser encontrada mesmo em momentos da vida ordinária e profana dessas sociedades.

Apesar de ter sido concebida a partir do estudo das sociedades indígenas, o fim último da teoria durkheimiana da ação ritual consiste em explicar o funcionamento das sociedades modernas, reduzindo-as ao mesmo mecanismo. De acordo com esse modelo, as sociedades modernas são consideradas como apenas uma variação possível da lógica de desenvolvimento das sociedades. Vista sob esse ângulo, a ação ritual durkheimiana se apresenta como uma teoria crítica da autoimagem racional das sociedades modernas, que se utilizam do Esclarecimento como um dogma para justificar sua excepcionalidade e ruptura como o padrão de desenvolvimento mítico e ritual das demais civilizações. Contra essa compreensão ideológica e dogmática, a teoria durkheimiana da ação ritual advoga em prol do conhecimento positivo dos padrões de continuidade e descontinuidade que caracterizam as sociedades, se interpondo como uma teoria crítica contra as falsas transparências da razão e reestabelecendo, assim, a dimensão crítica própria ao projeto do Esclarecimento. Em sua história evolucionária, a teoria durkheimiana da ação ritual interpreta o desenvolvimento das sociedades como uma espécie de big bang social (cf. WATTS MiLLER, 2012a, p. 128), em que o poder e as formas sociais outrora concentradas explodem, se fragmentam e se dispersam, num movimento contínuo de transformação e segmentação. Durante esse processo, as 
instituições que nasceram no meio religioso se secularizam, mas carregam consigo uma fração desse poder sagrado original, que continua a ser manipulado pela ação ritual das frações sociais engajadas em suas respectivas lógicas de funcionamento. Grosso modo, as instituições sociais seculares se distinguem em dois tipos principais. Figuram, por um lado, as instituições que se cristalizaram em formas hierarquizadas e definidas de administração do poder sagrado, tais como a Igreja e o Estado. Essas instituições objetivam intermediar a relação entre esse poder e as coletividades, visando domesticar as instabilidades que essas eventos produzem e preservar sua autoridade e status quo ao longo do tempo. Por outro lado, figuram as instituições que se organizam de maneira mais horizontal e contingente, como as manifestações anti-establishment, que se caracterizam precisamente pela irrupção descontrolada e selvagem do poder social contra a ordem vigente, sendo, pela mesma razão, voláteis e intermitentes. Em ambos os casos, as instituições lançam mão da linguagem dramática e estetizante para disputar os ideais que orientam o pensamento e ação coletivos. Nesse sentido, ainda que instituições hierárquicas tendam a cristalizar seu poder o longo do tempo, todas as instituições do mundo secular, inclusive o Estado e a Igreja, carregam sempre uma parcela do poder sagrado, que é continuamente tensionada por outros poderes - também parciais - na disputa pelo engajamento dos grupos para realização de seus projetos de futuro. Embora haja assimetrias das mais variadas entre essas instituições, todas dependem, em última análise, do poder sagrado engendrado pelos estados de eferverscência das coletividades que a ela aderem. Por essa razão, é a capacidade da ação ritual de transfigurar o mundo sensível em um mundo ideal, ou seja, de criar um delírio bem fundamentado em torno de um ideal desejável, que constitui a pedra de toque da disputa em prol da transformação - repetitiva ou revolucionária - das sociedades. Para a teoria durkheimiana da ação ritual, portanto, são as performances dramáticas coletivas e suas distintas capacidades de concentração e manipulação do poder sagrado que conformam os momentos de criação das ideias e práticas que prefiguram as possibilidades do devir das sociedades.

Enfim, a teoria durkheimiana estabelece a ação ritual como eixo de produção e reprodução da socialidade. Fundamentalmente coletivo, dramático e extático, seu mecanismo conduz à inevitável transfiguração e à produção de verdades mitológicas que reorientam, por sua vez, os horizontes de ação futura. Tal posição continua a 
desafiar as tanto as teorias que buscam no nível das interações individuais a racionalidade da ação coletiva, quanto aquelas que almejam que a ciência e seus produtos tenham um papel preponderante na condução da vida social. Para a teoria durkheimiana, as interações e ações individuais são sempre efeito, e não causa, das ideias e práticas criadas nos meios rituais efervescentes. Da mesma maneira, a ciência social pode almejar analisar a ação social e elaborar ideias transparentes que a traduzam sob a forma de conceitos, mas tal conhecimento é produzido às custas do distanciamento do locus do poder sagrado e da linguagem estetizante que criam, efetivamente, os ideais e propiciam a ação social. Em outros termos, o rigor analítico e a transparência das verdades científicas são inversamente proporcionais ao poder de ação e transfiguração das verdades mitológicas produzidas nos meios sociais efervescentes. Pode parecer paradoxal sustentar uma visão cientificamente informada e transparente do mundo social que revele, justamente, a perenidade dos mitos e ritos - que, longe de desaparecerem, continuam a se transformar e a organizar a vida social. E que, por mais estratificada e racional que pareça, a vida social continue a ser definida pelas irrupções das multidões, comumente vistas como manifestações irracionais e perigosas. Mas são precisamente esses paradoxos que a teoria durkheimiana da ação ritual pretende investigar, perseguindo a lógica subjacente à ação coletiva ou, simplesmente, os elementos que constituem o poder e a racionalidade das multidões. 


\section{Referências}

AlEXANDER, Jeffrey C. (1987). "Lecture one: what is theory?". In: Twenty lectures: sociological theory since World War II. New York: Columbia University Press.

(2005). "The inner development of Durkheim's sociological theory: from early writings to maturity”. In: AlEXANDER, J.; SMITH, P. (Ed.). The Cambridge companion to Durkheim. Cambridge: Cambridge University Press.

AlLEN, Nicholas J. (2000). Categories and classifications: Maussian reflections on the social. Oxford: Berghahn Books.

(2014). "Mauss, India, and perspectives from world history". Journal of

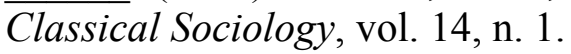

Barbeau, C. M. (1916). “Henri Beuchat”. American Anthropologist, vol. 18, n. 1.

BASTIDE, Roger (1958). Le candomblé de Bahia: rite nagô. Paris: Mouton.

BELIER, Wouter W. (1995). "Religion and magic: Durkheim and the Année sociologique group". Method \& theory in the study of religion, vol. 7, n. 2.

BERNDT, Ronald M. (1972). "Review: Songs of Central Australia". Anthropological Forum, vol. 3, n. 2.

BESNARD, Philippe (1979). "La formation de l'équipe de l'Année sociologique”. Revue française de sociologie, vol. 20, n. 1.

(2003). "La collaboration entre Durkheim et Mauss". In: Études

durkheimiennes. Genève: Droz.

BiAGioli, Mario (1990). "The anthropology of incommensurability". Studies in History and Philosophy of Science, vol. 21, n. 2.

CLARK, Terry Nichols (1968). "The structure and functions of a research institute: the Année sociologique". European Journal of Sociology, vol. 9, n. 1.

(1973). Prophets and patrons: the French university and the emergence of the social sciences. Cambridge: Harvard University Press.

ColLins, Randall (1995). "Les traditions sociologiques". Enquête, n. 2.

CotTerrell, Roger (2005). "Durkheim's Loyal Jurist? The Sociolegal Theory of Paul Huvelin”. Ratio Juris, vol. 18, n. 4. 
CZARnOwski, Stefan (1919). Le culte des héros et ses conditions sociales : Saint Patrick, héros national de l'Irlande. Paris : Félix Alcan.

DePloige, Simon; DurKheIM, Émile (1907). “A propos du conflit de la morale et de la sociologie. Letres de M. Durkheim et réponses de S. Deploige". Revue néo-scolastique, n. 56.

DURKHEIM, Émile (1886). "Les études de science sociale". Revue philosophique de la France et de l'étranger, vol. 22.

(1887a). “J. M. Guyau, L'irreligion de l'avenir". Revue philosophique de la France et de l'étranger, vol. 23.

(1887b). "La Science positive de la morale en Allemagne". Revue philosophique de la France et de l'étranger, vol. 24.

(1890). "Les principes de 1789 et la sociologie". Revue internationale de l'enseignement, vol. 19.

([1892] 1997). Quid Secundatus Politicae Scientiae Instituendae Contulerit. Oxford: Durkheim Press.

(1893). De la division du travail social. Paris: Félix Alcan.

(1895a). Les règles de la méthode sociologique. Paris: Félix Alcan.

sociale, vol. 3 .

(1895b). "Lo Stato Attuale degli Studi Sociologici in Francia". La riforma

(1897a). Le suicide. Paris: Félix Alcan.

(1897b). “A. Labriola, Essais sur la conception matérialiste de l'histoire". Revue philosophique de la France et de l'étranger, vol. 44.

(1898a). "L'individualisme et les intellectuels". Revue politique et littéraire Revue bleue, vol. 10.

(1898b). "Représentations individuelles et représentations collectives". Revue de métaphysique et de morale, vol. 6, n. 3.

1.

(1898c). "La prohibition de l'inceste et ses origines". Année sociologique, vol.

(1898d). "M. Mauss, La religion et les origines du droit pénal”. Année sociologique, vol. 1.

(1898e). “J. Kohler, Zur Urgeschichte der Ehe”. Année sociologique, vol. 1.

(1898f). "E. Grosse, Die Formen der Familie und die Formen der Wirthschaft". Année sociologique, vol. 1.

(1899a). "Préface". Année sociologique, vol. 2. 
$\overline{2 .}$

(1899b). "De la définition des phénomènes religieux". Année sociologique, vol.

\section{2.}

(1899c). "Note sur la morphologie sociale". Année sociologique, vol. 2.

(1902). "Sur le totémisme”. Année sociologique, vol. 5.

(1903). "Systèmes juridiques”. Année sociologique, vol. 6.

(1905). "Sur l'organisation matrimoniale des sociétés australiennes". Année sociologique, vol. 8.

(1906). "Détermination du fait moral". Bulletin de la société française de philosophie, vol. 6.

(1909a). "Sociologie religieuse et théorie de la connaissance". Revue de

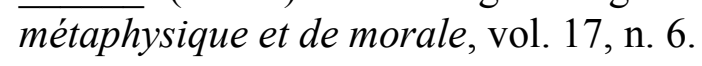

(1909b). "Examén critique des systèmes classiques sur les origines de la pensée religieuse". Revue philosophique de la France et de l'étranger, vol. 67.

(1911). "Jugements de valeur et jugements de réalité". Revue de métaphysique et de morale, vol. 19, n. 4.

(1912). Les formes élémentaires de la vie religieuse. Paris: Félix Alcan.

(1913). "Le problème religieux et la dualité de la nature humaine". Bulletin de la société française de philosophie, vol. 13. vol. XV.

(1914) "Le dualisme de la nature humaine et ses conditions sociales". Scientia,

(1925). L'éducation morale. Félix Alcan.

(1928). Le socialisme. Paris: Félix Alcan.

(1938). L'évolution pédagogique en France. Paris: Félix Alcan.

(1950). Leçons de sociologie. Paris: PUF.

(1955). Pragmatisme et sociologie. Paris: Vrin.

(1998). Lettres à Marcel Mauss. Paris: PUF.

(2020). "Un manuscrit inédit de Durkheim: Physique générale du droit et des

mours, IV $^{\mathrm{e}}$ année du Cours, $1^{\text {re }}$ Leçon, 2 décembre 1899, Plan du Cours - Les Sanctions pénales". Durkheimian Studies, vol. 24.

DurkHeIM, Émile; MAUSS, Marcel (1903). "De quelques formes primitives de classification”. Année sociologique, vol. 6.

(1910). “C. Strehlow, Die Aranda- und Loritja-Stämme in Zentral-Australien I, II’. Année sociologique, vol. 11. 
(1913). "G. Frazer, Totemism and Exogamy / E. Durkheim, Les formes élémentaires de la vie religieuse". Année sociologique, vol. 12.

EVANS-PRITICHARD, E. E. (1965). Theories of primitive religion. Oxford: Oxford University Press.

FAuCONNET, Paul; Mauss, Marcel (1901). "Sociologie". La Grande Encyclopédie. Vol. 30. Paris: Société Anonyme de la Grande Encyclopédie.

FontanA, Paul (1907). "Cours de M. Durkheim à la Sorbonne". Revue de philosophie, vol. 6 , n. 10-11.

FOURNIER, Marcel (1994). Marcel Mauss. Paris: Fayard.

(2007). Émile Durkheim. Paris: Fayard.

(2014). "Les formes élémentaires comme œuvre collective: les contributions

d'Henri Hubert et de Marcel Mauss à la sociologie de la religion tardive d'Émile Durkheim". Canadian Journal of Sociology, vol. 39, n. 4.

GRANET, Marcel (1919). Fêtes et chansons anciennes de la Chine. Paris: Ernest Leroux.

GIBSON, Jason (2017). “'Only the best is good enough for eternity': Revisiting the ethnography of T. G. H. Strehlow". In: Peterson, N.; KenNY, A. (Ed.). German ethnography in Australia. Canberra: ANU Press.

HERTZ, Robert (1907). "Contribution à une étude sur la repésentation collective de la mort”. Année sociologique, vol. 10.

(1909). "La préeminence de la main droite - étude sur la polarité religieuse". Revue philosophique de la France et de l'étranger, vol. 68.

(1922) "Le péché et l'expiation dans les sociétés primitives". Revue de l'histoire des religions, vol. 86 .

HubERT, Henri (1899). "H. Usener, Der Stoff der griechischen Epos". Année sociologique, vol. 2.

(1901a). "R. Campbell Thompson, The reports of the Magicians and Astrologers of Nineveh and Babylon in the Bristish Museum". Année sociologique, vol. 4.

(1901b). “A. Bouché-Leclerq, L’astrologie grecque”. Année sociologique, vol.

4.

(1901c). "W. Warde Fowler, The Roman Festivals of the period of the Republic". Année sociologique, vol. 4.

vol. 4.

(1901d). “A. Nutt, The Fairy Mythology of Shakespeare”. Année sociologique,

(1901e). “A. Dorner, Grundriss der Dormengeschichte”. Année sociologique, vol. 4. 
(1901f). “E. Aust, Die Religion der Römer”. Année sociologique, vol. 4.

(1902a). "B. Spencer et F. J. Gillen, The Native tribes of Central Australia". Revue de l'histoire des religions, vol. 45.

(1902b). "S. Reinach, Le totémisme animal et Les survivances du totémisme chez les anciens Celtes". Année sociologique, vol. 5.

(1902c). "G. Hoensbroech, Das Papstthum in seiner sozial-kulturellen Wirksamkeit”. Année sociologique, vol. 5.

(1902d). "Le rituel - Introduction". Année sociologique, vol. 5.

(1902e). "Le contes - Introduction". Année sociologique, vol. 5.

(1902f). "Sociologie esthétique - Introduction”. Année sociologique, vol. 5.

(1902g). "H. Ouvré, Les formes littéraires de la pensée grecque". Année sociologique, vol. 5.

([1902] 1904). "Magia”. In: SAglio, Edmond; DAREMBERG, Charles (Org.). Dictionnaire des Antiquités Grecques et Romaines. Tome III, deuxième partie (L-M). Paris: Hachette. vol. 6.

(1903a). "R. Wuensch, Das Frühlingsfest der Insel Malta”. Année sociologique,

(1903b). "L. Pineau, Les viex chants populaires scandinaves". Année sociologique, vol. 6 .

(1904). "Introduction". In: ChantePIE DE LA SAussaye, P. D. Manuel d'histoire des religions. Paris: Armand Colin.

(1905a). "Étude sommaire de la représentation du temps dans la religion et la magie". Rapport sommaire sur les conférences de l'exercice 1904-1905 et le programme des conférences pour l'exercice 1905-1906. Paris: École Pratique de Hautes Études, Section des sciences religieuses.

(1905b). "Religions Primitives de l'Europe". Rapport sommaire sur les conférences de l'exercice 1904-1905 et le programme des conférences pour l'exercice 1905-1906. Paris: École Pratique de Hautes Études, Section des sciences religieuses.

(1905c). "H. Reich, Der Mimus / E. K. Chambers, The medieval stage". Année sociologique, vol. 8 .

(1906). "E. Lucius, Die Anfänge der Heiligen Kultus in der christichem Kirche”. Année sociologique, vol. 9.

(1907a). "A, Lods, La croyance à la vie future et le culte des morts dans l'antiquité israélite". Année sociologique, vol. 10.

(1907b). "W. H. Roscher, Die Sieben und Neunzal im Kultus der Grieehen”. Année sociologique, vol. 10. 
(1907c). "O. Gruppe, Griechische Mythologie und Religionsgeschichte”. Année sociologique, vol. 10.

(1907d). "Religions Primitives de 1'Europe". Rapport sommaire sur les conférences de l'exercice 1906-1907 et le programme des conférences pour l'exercice 1907-1908. Paris: École Pratique de Hautes Études, Section des sciences religieuses.

(1908). "Religions Primitives de l'Europe". Rapport sommaire sur les conférences de l'exercice 1907-1908 et le programme des conférences pour l'exercice 1908-1909. Paris: École Pratique de Hautes Études, Section des sciences religieuses.

(1910). "Religions Primitives de l'Europe". Rapport sommaire sur les conférences de l'exercice 1909-1910 et le programme des conférences pour l'exercice 1910-1911. Paris: École Pratique de Hautes Études, Section des sciences religieuses.

(1914a). "Religions Primitives de l'Europe". Rapport sommaire sur les conférences de l'exercice 1913-1914 et le programme des conférences pour l'exercice 1914-1915. Paris: École Pratique de Hautes Études, Section des sciences religieuses.

(1914b). "Le culte des héros et ses conditions sociales". Revue de l'histoire des religions, vol. 70.

(1915). "Le culte des héros et ses conditions sociales (deuxième article)". Revue de l'histoire des religions, vol. 71 .

(2012). “Lettres d'Henri Hubert à Marcel Mauss”. In: Bert, J.-F. (Ed.). Marcel Mauss, Henri Hubert et la sociologie des religions: penser et écrire à deux. Paris: La Cause des Livres.

HUBERT, Henri; MAUSS, Marcel (1899). "Essai sur la nature et la fonction du sacrifice". Année sociologique, vol. 2.

(1904). "Esquisse d'une théorie générale de la magie”. Année sociologique, vol.

7.

(1908). "Introduction à l'analyse de quelques phénomènes religieux". Revue de l'histoire des religions, vol. 58.

(2021). Correspondance (1897-1927). Édition de Rafael Faraco Benthien, Christophe Labaune et Christine Lorre. Paris: Classiques Garnier.

ISAMBERT, François-Andre (1976). "L'élaboration de la notion de sacré dans l'école durkheimienne". Archives de sciences sociales des religions, n. 42.

(1979). "Henri Hubert et la sociologie du temps". Revue française de sociologie, vol. 20 , n. 1.

JAMES, Wendy (2014). "Human life as drama: A Maussian insight". Journal of Classical Sociology, vol. 14, n. 1.

JOAS, Hans; KNÖBL, Wolfgang (2009). "What is theory?”. In: Social theory: twenty introductory lectures. Cambridge: Cambridge University Press. 
JONES, Robert Alun (1981). "Robertson Smith, Durkheim and sacrifice: an historical context for The elementary forms of the religious life". Journal of the History of the Behavioral Sciences, vol. 17.

(2005a). The secret of the totem: religion and society to McLennan to Freud. New York: Columbia University Press.

(2005b). "Practices and presuppositions: some questions about Durkheim and Les Formes élémentaires de la vie religieuse”. In: AleXANDER, J.; SMITH, P. (Ed.). The Cambridge companion to Durkheim. Cambridge: Cambridge University Press.

JONES, W. T. (1943). "On the Meaning of the Term 'Influence' in Historical Studies". Ethics, vol. 53. n. 3.

KARSENTI, Bruno (1996). "De Durkheim à Mauss. La spécificité psychologique de la sociologie". In: BORLANDI, M.; MUCCHIELLI, L (Org.). La sociologie et as méthode: les Règles de Durkheim un scièle après. Paris: L'Harmattan.

(1997). L'homme total: sociologie, anthropologie et philosophie chez Marcel Mauss. Paris: PUF.

(1998). "The maussian shift: a second fondation for sociology in France?". In: James, W.; Allen, N. J (Ed.). Marcel Mauss: a centenary tribute. New York: Berghahn Books.

Kenny, Anna (2013). The Aranda's Pepa: an introduction to Carl Strehlow's masterpiece Die Aranda-und Loritja-Stamme in Zentral Australien (1907-1920). Canberra: ANU Press.

(2017). "Early ethnographic work at the Hermannsburg Mission in Central Australia, 1877-1910". In: PETERSON, N.; KenNY, A. (Ed.). German ethnography in Australia. Canberra: ANU Press.

KISS, Olga (2006). "Heuristic, Methodology or Logic of Discovery? Lakatos on Patterns of Thinking". Perspectives on Science, vol. 14. n. 3.

KuHn, Thomas (2000). The Road Since Structure. Chicago: Chicago University Press.

LAKATOS, Imre (1970). "Falsification and the methodology of scientific research programmes". In: LaKatos, I; Musgrave, A (Ed.). Criticism and the Growth of Knowledge. London: Cambridge University Press.

Lalande, André (1906). "Philosophy in France (1905)". Philosophical Review, vol. 15, n. 3 .

LAPIE, Paul (1979). "Lettres de Paul Lapie à Célestin Bouglé". Revue française de sociologie, vol. 20, n. 1.

LE MALÉFAn, Pascal (2005). "Léon Marillier, figure de la psychologie naissante (18621901)". Bulletin de psychologie, n. 476. 
Leroi-Gourham, André (1964). Le geste et la parole: technique et langage. Paris: Albin Michel.

(1965). Le geste et la parole: la mémoire et les rythmes. Paris: Albin Michel.

LÉVI-Strauss, Claude (1945). "French sociology". In: Gurvitch, G.; MoORe, W. (Ed.). Twentieth Century Sociology. New York: Philosophical Library.

LUKES, Steven ([1973] 1975). Émile Durkheim: His Life and Work. Harmondsworth: Penguin.

MARCEL, Jean-Christophe (2001). Le dukheimisme dans l'entre-deux-guerres. Paris: PUF.

MASSELla, Alexandre Braga (2009). "Leituras da escola durkheimiana". In: MASSELLA, A. B.; Pinheiro Filho, F.; Augusto, M. H. O.; Weiss, R. (Org.). Durkheim: 150 anos. Belo Horizonte: Argvmentvm.

MARTELli, Stefano (1996). "Mana ou sacré? La contribution de Marcel Mauss à la fondation de la sociologie religieuse". Revue européenne des sciences sociales, vol. 34, n. 105.

MAUSS, Marcel (1896). "La religion et les origines du droit pénal - d'après un livre récent". Revue de l'histoire des religions, vol. 34.

(1897). "La religion et les origines du droit pénal - d'après un livre récent $\left(2^{\mathrm{e}}\right.$ et dernier article)". Revue de l'histoire des religions, vol. 35.

(1898a). “Année sociologique (Premiere Année, 1896-1897)”. Internationales Archiv fur Ethnographie, vol. 11.

(1898b). “A. Hillebrandt, Ritual-Litteratur - Vedische Opfer and Zauber". Année sociologique, vol. 1.

(1898c). "F. B. Jevons, An Introduction to the History of Religions". Année sociologique, vol. 1.

(1898d). "L. Marillier, La place du totémisme dans l'évolution religieuse". Année sociologique, vol. 1.

(1898e). "W. Crooke, The Popular Religions and Floklore of Northern India". Année sociologique, vol. 1.

(1898f). "A. Sabatier, Esquisse d'une philosophie de la religion d'après la psychologie et l'histoire”. Année sociologique, vol. 1.

(1899a). “A. Macdonnell, Vedic Mythology”. Année sociologique, vol. 2.

(1899b). “L. Duchesne, Origines du culte chrétien”. Année sociologique, vol. 2.

(1899c). "P. Tiele, Inleiding tot de Godsdienst Wetenschap". Année sociologique, vol. 2. 
(1899d). "L. Duchesne, Origines du culte chrétien”. Année sociologique, vol. 2.

(1900a). "S. Lévi, La doctrine du sacrifice chez les Brâhmanas". Année sociologique, vol. 3.

(1900b). “J. G. Frazer, The Origin of Totemism”. Année sociologique, vol. 3.

(1900c). "B. Spencer et F. Gillen, The Native Tribes of Central Australia". Année sociologique, vol. 3.

(1900d). "T. Witton Davies, Magic, Divination, and Demonology, among the Hebrews ans their Neighbours". Année sociologique, vol. 3.

(1900e). “L. Blau, Das altjüdische Zauberwesen”. Année sociologique, vol. 3.

(1902a). "L'enseignement de l'histoire des religions des peuples non-civilisés a l'École des Hautes Études". Revue de l'histoire des religions, vol. 45.

(1902b). “L. Marillier, Religion”. Année sociologique, vol. 5.

(1902c). “J. G. Frazer, The Golden Bough”. Année sociologique, vol. 5.

(1902d). "E. Murisier, Les malaides du sentiment religieux". Année sociologique, vol. 5.

(1902e). "I. Religions des peuples non civilisés". Rapport sommaire sur les conférences de l'exercice 1901-1902 et le programme des conférences pour l'exercice 1902-1903. Paris: École Pratique de Hautes Études, Section des sciences religieuses.

(1903a). “Th. Achelis, Die Extase, Kulturprobleme der Gegenwart”. Année sociologique, vol. 6.

6.

(1903b). "F. B. Gummere, The Beginnings of Poetry". Année sociologique, vol.

(1903c). "Memoirs of the American Museum of Natural History". Année

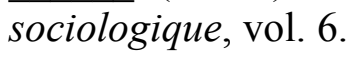

(1903d). "Représentations religieuses d'êtres et de phénomènes naturels". Année sociologique, vol. 6.

(1903e). "I. Religions des peuples non civilisés". Rapport sommaire sur les conférences de l'exercice 1902-1903 et le programme des conférences pour l'exercice 1903-1904. Paris: École Pratique de Hautes Études, Section des sciences religieuses.

(1903f). "E. von der Goltz, Das Gebet in der ältesten Christenheit". Année sociologique, vol. 6 .

(1904a). "L'origine des pouvoirs magiques dans les sociétés australiennes étude analytique et critique de documents ethnographiques". Rapport sommaire sur les conférences de l'exercice 1903-1904 et le programme des conférences pour l'exercice 1904-1905. Paris: École Pratique de Hautes Études, Section des sciences religieuses. 

vol. 7.

(1904b). "Philosophie religieuse, conceptions générales". Année sociologique,

(1904c). "K. Girgensohn, Die Religion, ihre psychischen nach dem Wesen der Zentralidee". Année sociologique, vol. 7.

(1904d). "I. Religions des peuples non civilisés". Rapport sommaire sur les conférences de l'exercice 1903-1904 et le programme des conférences pour l'exercice 1904-1905. Paris: École Pratique de Hautes Études, Section des sciences religieuses.

(1904e). "F. Boas, The Eskimo of Baffin Land and Hudson Bay / E.-W. Nelson, The Eskimo about Bering Strait". Année sociologique, vol. 7.

(1904f). "J. W. Fewkes, Notes on Tusayan Snake and Flute Ceremonies / Minor Hopi Festivals / Sky God Personations, in the Hopi Worship / G. A. Dorsey et R. V. Voth, The Mishongnovi Ceremonies of the Snake and Antelope Fraternities". Année sociologique, vol. 7.

(1904g). "J. Mooney, Calendar History of the Kiowa Indians". Année sociologique, vol. 7.

(1905a). "Note sur le totémisme". Année sociologique, vol. 8.

(1905b). "B. Spencer et F. Gillen, The Northern Tribes of Central Australia". Année sociologique, vol. 8.

(1905c). "I. Religions des peuples non civilisés". Rapport sommaire sur les conférences de l'exercice 1904-1905 et le programme des conférences pour l'exercice 1905-1906. Paris: École Pratique de Hautes Études, Section des sciences religieuses.

(1905d). “A. Mathiez, Les Origines de Cultes Révolutionnaires / La Théophilanthropie et le Culte Décadaire". Année sociologique, vol. 8.

(1906). “A. W. Howitt, The Native Tribes of South East Australia”. Année sociologique, vol. 9.

(1906b). "I. Religions des peuples non civilisés". Rapport sommaire sur les conférences de l'exercice 1905-1906 et le programme des conférences pour l'exercice 1906-1907. Paris: École Pratique de Hautes Études, Section des sciences religieuses.

(1907a). "J. G. Frazer, The Beginnings of Religion and Totemism among the Australian Aborigines". Année sociologique, vol. 10.

(1907b). "K. Breysig, Die Entstehung des Gottesgedankens und der Heilbringer". Année sociologique, vol. 10. $\overline{\text { vol. } 10 .}$

(1907c). “A. van Gennep, Mythes et légendes d'Australie”. Année sociologique,

(1907d). "H. Hubert, Étude sommaire de la représentation tu temps dans la religion et la magie". Année sociologique, vol. 10. 
(1907e). "I. Religions des peuples non civilisés". Rapport sommaire sur les conférences de l'exercice 1906-1907 et le programme des conférences pour l'exercice 1907-1908. Paris: École Pratique de Hautes Études, Section des sciences religieuses.

(1908a). "I. Religions des peuples non civilisés". Rapport sommaire sur les conférences de l'exercice 1907-1908 et le programme des conférences pour l'exercice 1908-1909. Paris: École Pratique de Hautes Études, Section des sciences religieuses.

(1908b). "L'art et le mythe d'après M. Wundt". Revue philosophique de la France et de l'étranger, vol. 66.

(1909a). La prière - les origines. Paris: Félix Alcan.

(1909b). "I. Religions des peuples non civilisés". Rapport sommaire sur les conférences de l'exercice 1908-1909 et le programme des conférences pour l'exercice 1909-1910. Paris: École Pratique de Hautes Études, Section des sciences religieuses.

(1910a). "J. R. Swanton, Contributions to the Ethnology of the Haida / Social condition, Beliefs and Linguistic Relationship of the Tlingit Indians / Haida Texts and Myths". Année sociologique, vol. 11.

(1910b). "W. Bogoras, The Chukchee / W. Jochelson, The Koryak. Année sociologique, vol. 11.

(1910c). "F. Krause, Die Pueblo Indianer / M. C. Stevenson, The Zuñi Indians / H. Voth, The Traditions of the Hopi / H. Eickhoff, Die Kultur des Pueblos in Arizona und New-Mexico". Année sociologique, vol. 11.

(1910d). "W. Wundt, Völkerpsychologie - Mythus und Religion II, III". Année sociologique, vol. 11.

(1910e). "I. Religions des peuples non civilisés". Rapport sommaire sur les conférences de l'exercice 1909-1910 et le programme des conférences pour l'exercice 1910-1911. Paris: École Pratique de Hautes Études, Section des sciences religieuses.

(1911a). "I. Religions des peuples non civilisés". Rapport sommaire sur les conférences de l'exercice 1910-1911 et le programme des conférences pour l'exercice 1911-1912. Paris: École Pratique de Hautes Études, Section des sciences religieuses.

(1911b). “Anna-Virãj”. Mélanges d'indianisme offerts par ses élèves à M. Sylvain Lévy. Paris: Ernerst Leroux.

(1912). "I. Religions des peuples non civilisés". Rapport sommaire sur les conférences de l'exercice 1911-1912 et le programme des conférences pour l'exercice 1912-1913. Paris: École Pratique de Hautes Études, Section des sciences religieuses.

(1913a). "I. Religions des peuples non civilisés". Rapport sommaire sur les conférences de l'exercice 1912-1913 et le programme des conférences pour l'exercice 1913-1914. Paris: École Pratique de Hautes Études, Section des sciences religieuses.

(1913b). “C. Strehlow, Die Aranda- und Loritja-Stämme in Zentral-Australien III". Année sociologique, vol. 12. 
(1913c). "J. Segond, La prière - Essai de psychologie religieuse". Année sociologique, vol. 12.

(1914a). "I. Religions des peuples non civilisés". Rapport sommaire sur les conférences de l'exercice 1913-19134 et le programme des conférences pour l'exercice 1914-1915. Paris: École Pratique de Hautes Études, Section des sciences religieuses.

(1914b). "Les origines de la notion de monnaie". Comptes rendus dés séances de l'Institut Français d'Anthropologie, vol. 1.

(1914c) "Le tabou de la belle-mère". Comptes rendus dés séances de l'Institut Français d'Anthropologie, vol. 2.

(1914d) "Le tabou de la belle-mère chez les Baronga". Anthropologie, vol. 25.

(1947). Manuel d'ethnographie. Paris: Payot.

(2011). "De l'utilité des recherches de sociologie descriptive dans l'Indochine française". Genèses, n. 84.

(2012). “Lettres de Marcel Mauss à Henri Hubert”. In: BERT, J.-F. (Ed.). Marcel Mauss, Henri Hubert et la sociologie des religions: penser et écrire à deux. Paris: La Cause des Livres.

(2015). "Réduction des divers éléments de la magie à la notion de pouvoir et de force". Revue du MAUSS, n. 45.

Mauss, Marcel; Beuchat, Henri (1906). "Essai sur les variations saisonnières des sociétés eskimos: étude de morphologie sociale". Année sociologique, vol. 9.

MÉTRAUX, Alfred (1928). La religion des Tupinamba. Paris: Ernest Leroux (1967). Religion et magies indiennes d'Amérique du Sud. Paris: Gallimard.

Meylan, Nicolas (2017). Mana: A History of a Western Category. Leiden: Brill.

MoEBIUS, Stephan (2011). "Die Religionssoziologie von Marcel Mauss". Zeitschrift für Religionswissenschaft, vol. 19, n. 1-2.

MORPHY, Howard (2003). "Some Concluding Anthropological Reflections". In: MAUSS, Marcel. On Prayer. Oxford: Berghahn / Durkheim Press.

MucChiElli, Laurent (1998). La découverte du social: naissance de la sociologie en France. Paris: La Découverte.

(2001). "O nascimento da sociologia na universidade francesa (1880-1914)". Revista brasileira de História, São Paulo, vol. 21, n. 41, p. 35-54.

NANDAN, Yash (1977). The Durkheimian School: a systematic and compreensive bibliography. Westport: Greenwood Press.

(1980). "Editors introduction". In: DuRKhEIM, E. Contributions to l'Année sociologique. New York: Free Press. 
OLIVER, Laurent (Ed.) (2017). La mémoire et le temps: l'œuvre transdisciplinaire d'Henri Hubert. Paris: Demopolis.

OzUF, Mona (1988). Festivals and the French Revolution. Cambridge: Harvard University Press.

PaOletTI, Giovanni (2012). "Les deux tournants, ou la religion dans l'œuvre de Durkheim avant Les formes élémentaires". Année sociologique, vol. 62, n. 2.

PARKIN, Robert (1996). The Dark Side of Humanity: The Work of Robert Hertz and its Legacy. London: Routledge.

PARSONS, Talcott ([1937] 1966). The Structure of Social Action. New York: The Free Press.

Paulme, Denise (1940). Organisation sociale des Dogon. Paris: Domat-Montchrestien. (1956). Les sculptures de l'Afrique noire. Paris: PUF.

PICKERING, William S. F ([1984] 2009). Durkheim's sociology of religion: themes and theories. Cambridge: James Clark \& Co.

(2003). "Introduction to an Unfinished Work". In: MAUss, Marcel. On Prayer. Oxford: Berghahn / Durkheim Press.

(2012). "How compatible were Durkheim and Mauss on matters relating to religion? Some introductory remarks". Religion, vol. 42, n. 1.

PINHEIRO FiLHo, Fernando Antônio (1996). A mente do todo: o encontro da sociologia durkheimiana com a questão do tempo. Dissertação de Mestrado, Faculdade de Filosofia, Letras e Ciências Humanas, Universidade de São Paulo, São Paulo.

PTACEK, Melissa (2015). "Durkheim's two theories of sacrifice - ritual, social change and Les formes élémentaires de la vie religieuse". Durkheimian Studies, vol. 21.

RosA, Frederico Delgado (2019). "William Robertson Smith sacrifié: promiscuité intellectuelle et métamorphose chez Durkheim". In: BÉRA, M.; SEMBEL, N. (Ed.). Les formes élémentaires de la vie religieuse, cent ans après. Paris: Classiques Garnier.

SAladin D'AngluRe, Bernard (Ed.) (2006). "L'influence de Marcel Mauss". Études Inuit, vol. 30, n. 2.

SCHMAUS, Warren (1992). "Research programs as intellectual niches". Social Epistemology, vol. 6, n. 1.

SchUlze, Louis (1891). "The Aborigines of the Upper and Middle Finke River". Transactions and Proceedings of the Royal Society of South Australia, vol. XIV, part II.

Sigaud, Lygia (2002). “The Vicissitudes of The Gift". Social Anthropology, vol. 10, n. 3.

SMith, Philip (2020). Durkheim and After: The Durkheimian Tradition, 1893-2020. Cambridge: Polity Press. 
Spencer, B.; Gillen, F. J. (1899). The Native Tribes of Central Australia. London: Macmillan.

(1904). The Northern Tribes of Central Australia. London: Macmillan.

StAnNeR, W. E. H. (1967). "Reflections on Durkheim and aboriginal religion". In: FREEDMAN, Maurice (Ed.). Social organization: essays presented to Raymond Firth. Chicago: Aldine.

STEINER, Philippe (2001). "Religion et économie: Mauss, Simiand et le programme durkheimien". Revue française de sociologie, vol. 42, n. 4.

(2005). L'école durkheimienne et l'économie: sociologie, religion et connaissance. Genève: Droz.

Strehlow, T. G. H. (1971). Songs of Central Australia. Sydney: Angus and Robertson.

SuMPF, Joseph (1965). "Durkheim et le problème de l'étude sociologique de la religion". Archives des sciences sociales des religions, n. 20.

TARot, Camille (1999). De Durkheim à Mauss, l'invention du symbolique: sociologie et science des religions. Paris: La Découverte.

Tiryakian, Edward A. (1978). "Emile Durkheim”. In: Bottomore, T; NisBet, R. (Ed.). A history of sociological analysis. Farnham: Ashgate.

(1979). "The Significance of Schools in the Development of Sociology". In: SnizeK, W.; Fuhrman, E.; Miller, M. (Ed.). Contemporary Issues in Theory and Research: A Metasociological Perspective. Westport: Greenwood Press.

(1986). "Hegemonic Schools and the Development of Sociology". In: MONK, R. C. (Ed.). Structures of Knowing: Current Studies in the Sociology of Schools. Lanham: University Press of America.

(1988). "Durkheim, Mathiez, and the French Revolution: the political context of a sociological classic". European Journal of Sociology, vol. 29, n. 2.

URBACH, Peter (1978). "The Objective Promise of a Research Programme". In: RADNitZKY, G.; ANDERSSON, G. (Ed.). Progress and rationality in science. Dordrecht: D. Reidel.

VAN DER WUSTEN, Herman (2005). "Sebald Rudolf Steinmetz (1862-1940)". In: Armstrong, P. H.; Martin, G. J. Geographers: Biobibliographical Studies. Vol. 24. London: Thoemmes Continuum.

VoGT, Paul W. (1983). "Obligation and right: the Durkheimians and the sociology of law". In: BESNARD, P. (Ed.). The sociological domain: the Durkheimians and the founding of French sociology. Cambridge: Maison des Sciences de l'Homme / Cambridge University Press.

WALLWORK, Ernest (1985). "Durkheim's early sociology of religion". Sociological analysis, vol. 46, n. 3. 
WATts MiLler, William (1996). Durkheim, morals and modernity. London: UCL Press.

(2000). 'Durkheimian Time”. Time \& Society, vol. 9, n. 1, p. 5-20.

Books.

(2012a). A Durkheimian quest: solidarity and the sacred. Oxford: Berghahn

(2012b). "Durkheim's re-imagination of Australia: A case study of the relation between theory and "facts"'. Année sociologique, vol. 62, n. 2.

(2013). "Total Aesthetics: Art and The Elemental Forms". In: RiLEY, A.; PICKERING, W.S.F.; WatTs Miller, W. (Ed.). Durkheim, the Durkheimians and the Arts. Oxford: Berghahn Books.

WEISS, Raquel (2011). "From Ideas to Ideals: Effervescence as the Key to Understanding Morality”. Durkheimian Studies, vol. 18. vol. 19 .

(2013). "Efervescência, dinamogenia e a ontogênese social do sagrado". Mana,

WraY, K. Brad (2011). Kuhn's Evolutionary Social Epistemology. Cambridge: Cambridge University Press.

(2015). "Kuhn's Social Epistemology and the Sociology of Science". In: DEVlin, W. J.; BoKUlich, A. (Ed.). Kuhn's Structure of Scientific Revolutions - 50 years on. New York: Springer. 